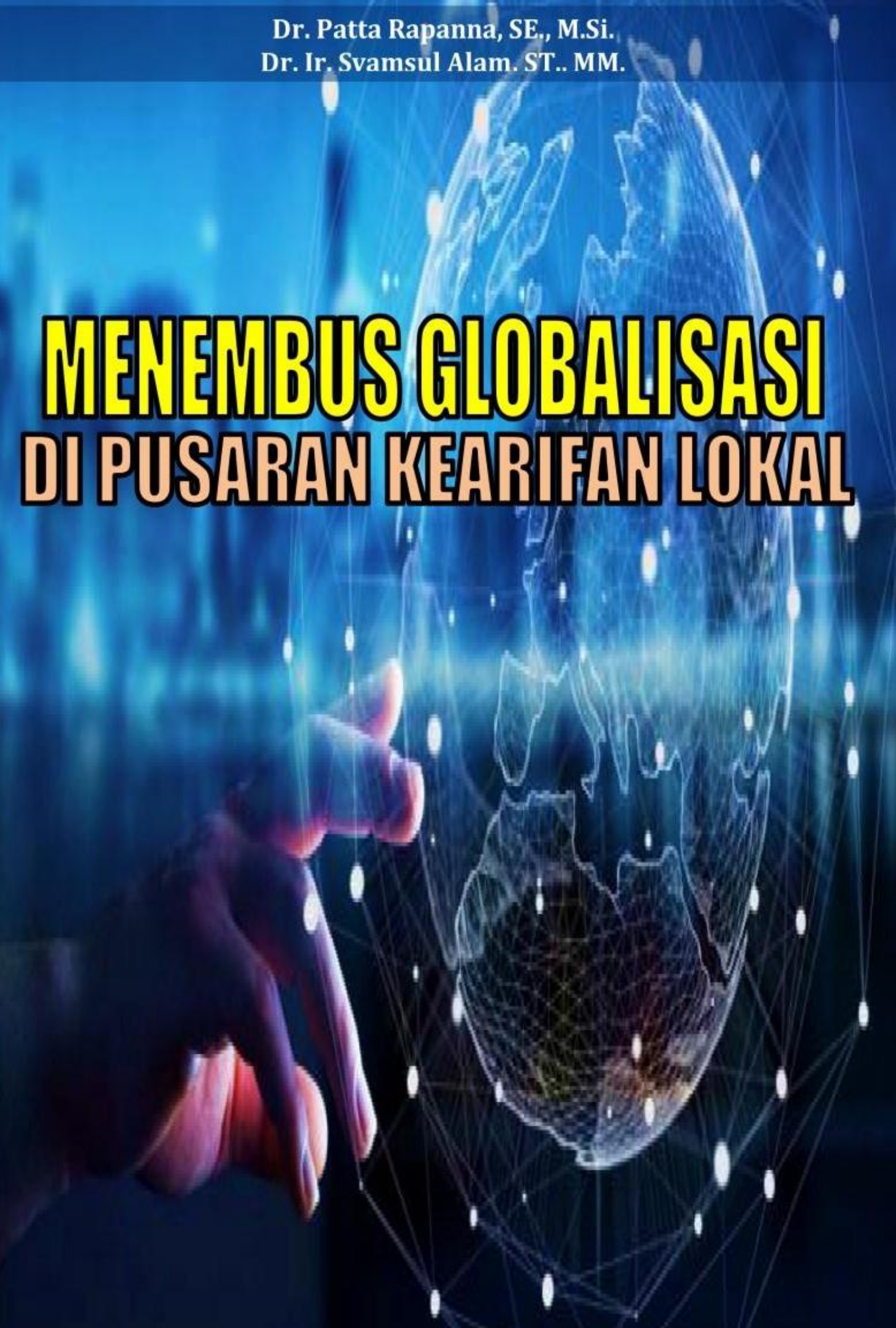



Dr. Patta Rapanna, SE., M.Si.

Dr. Ir. Syamsul Alam, ST., MM.

\section{MENEMBUS GLOBALISASI DI PUSARAN KEARIFAN LOKAL}

Yayasan Barcode 2021 
Sanksi Pelanggaran Pasal 72

Undang-Undang Nomor 19 Tahun 2002 Tentang Hak Cipta

1. Barang siapa dengan sengaja dan tampa hak melakukan perbuatan Sebagaimana dimaksud dalam pasal 2 ayat (1) atau pasal 49 ayat (1) dan ayat 2 dipidana dengan pidana penjara masing-masing paling singkat 1 (satu) bulan dan / atau denda paling sdikit Rp. 1.000.000.00 (satu juta), atau pidana penjara paling lama 7 (tujuh) Tahun dan/atau denda paling banyak Rp. 5.000.000.000;00 (lima milyar rupiah.

2. Barang siapa dengan sengaja menyiarkan, memamerkan, mengedarkan atau menjual kepada umum suatu ciptaan atau barang hasil pelanggaran Hak Cipta terkait bagaimana dimaksud pada ayat (1) pidana dengan pidana penjara paling lama 5 (lima) tahun dan/atau denda paling banyak Rp. 500.000.000.00; (lima ratus juta rupiah).

\section{Judul Buku}

ISBN

Penulis

Cetakan Ukuran Buku Layout oleh
: MENEMBUS GLOBALISASI DI PUSARAN KEARIFAN LOKAL

: 978-623-285-738-4

: Dr. Patta Rapanna, SE., M.Si. Dr. Ir. Syamsul Alam, ST., MM.

: Pertama Desember 2021

: $15 \times 23 \mathrm{~cm}$

: Sulaiman

\section{Diterbitkan Oleh}

\section{Penerbit Yayasan Barcode}

Divisi Publikasi dan Penelitian

Jl. Kesatuan 3 No. 9 Kelurahan Maccini Parang Kecamatan Makassar Kota Makassar 


\section{KATAPENGANTAR}

Globalisasi merupakan satu proses untuk meletakkan dunia di bawah satu unit yang sama tanpa dibatasi oleh sempadan dan kedudukan geografi di sebuah negara. Melalui proses ini, dunia akhirnya tidak lagi mempunyai sempadan dengan ruang udara dan langit. Sesebuah negara itu mempunyai peluang yang luas untuk menerima berbagai maklumat yang disalurkan menerusi sebagai perantaraan media komunikasi seperti internet, media elektronik dan teknologi siber. Perkembangan ini memudahkan manusia terutamanya dalam perhubungan yaitu di antara sebuah negara dengan negara yang lain ataupun perhubungan sesama manusia. Melalui perkembangan ini, sesuatu perhubungan itu dapat dilakukan dalam tempo yang singkat dan cepat. Dalam era globalisasi ini, ruang dunia semakin mengecil dari hari ke hari. Jika dahulu dunia ini seluas sejauh mata memandang dan dipagari dengan sempadansempadan namun kini ia tidak berlaku lagi. Malah pada hari ini, kita merasakan apakah sebenarnya maksud dari globalisasi itu sendiri. Selain itu, ledakan teknologi maklumat yang kian pesat merupakan medium utama kepada perkembangan dan kepesatan globalisasi itu sendiri telah menjangkau sempadan ekonomi, teknologi, bahasa, budaya, ideologi, politik dan keseluruhan aspek kehidupan sebuah masyarakat.

kearifan lokal merupakan unsur bagian dari tradisibudaya masyarakat suatu bangsa, Sekalipun bangsa itu telah modern dan mengalami kemajuan yang pesat, kearifan lokal muncul menjadi bagian-bagian yang ditempatkan pada tatanan fisik bangunan (arsitektur) dan kawasan 
(perkotaan) dalam geografi kenusantaraan sebuah bangsa. kearifan lokal merupakan langkah penerapan dari tradisi yang diterjemahkan dalam artefak fisik. Hal terpenting dari kearifan lokal adalah proses sebelum implementasi tradisi pada artefak fisik, yaitu nilai-nilai dari alam untuk mengajak dan mengajarkan tentang bagaimana 'membaca' potensi alam dan menuliskannya kembali sebagai tradisi yang diterima secara universal oleh masyarakat, khususnya dalam berarsitektur. Nilai tradisi untuk menselaraskan kehidupan manusia dengan cara menghargai, memelihara dan melestarikan alam lingkungan. Hal ini dapat dilihat bahwa semakin adanya penyempurnaan arti dan saling mendukung, yang intinya adalah memahami bakat dan potensi alam tempatnya hidup; dan diwujudkannya sebagai tradisi, definisi kearifan lokal secara bebas dapat diartikan nilai-nilai budaya yang baik yang ada di dalam suatu masyarakat. Hal ini berarti, untuk mengetahui suatu kearifan lokal di suatu wilayah maka kita harus bisa memahami nilai-nilai budaya yang baik yang ada di dalam wilayah tersebut.

Makassar Desember 2021

Penulis

Patta Rapannna / Syamsul Alam 


\section{DAFTAR ISI}

BAB 1 CAKRAWALA GLOBALISASI DAN PEMBANGUNAN 01

A. Pengertian dan Dampak Globalisasi ................................ 01

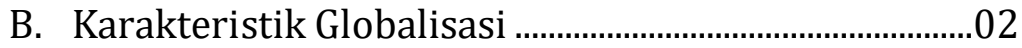

C. C.Bentuk dan Gejala Globalisasi .......................................02

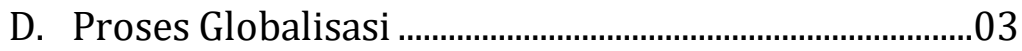

E. Globalisasi Dan Pembangunan Di Indonesia................04

F. Dampak Globalisasi Terhadap Pembangunan ............07

G. Pembangunan Berkelanjutan..........................................11

H. Partisipasi Masyarakat Dalam Pembangunan.............13

BAB 2 SDM DAN PENGUATAN PEMBANGUNAN 18

A. Pengertian Manajemen Smber Daya Manusia (MSDM) .........................................................................18

B. Pentingnya SDM yang Berkualitas Dalam suatu Pembangunan Nasional maupun Daerah .....................18

C. SDM Sebagai Pilar suatu Pencapaian Pembangunan 20

D. Masalah-masalah Peningkatan SDM dalam Upaya Pencapaian Tujuan Pembangunan Daerah ..................20

E. Solusi Mengatasi Masalah Sumber Daya Manusia untuk Mencapai Pembangunan yang Berkelanjutan23

BAB 3 GLOBALISASI DAN BADAI EKONOMI..............................26

A. Pengertian Globalisasi .....................................................26

B. Dampak Positif Globalisasi dalam Bidang Ekonomi 28

C. Pengaruh Negatif Globalisasi dalam Ekonomi ............29

D. Cara Menanggulangi Dampak Negatif Globalisasi Bagi Bangsa dan Negara dalam Bidang Ekonomi, .....30

E. Globalisasi: Definisi, Peran, dan Ruang Lingkup .........31

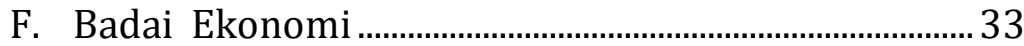

BAB 4 MENATA SDM UNGGULAN ................................................38

A. Strategi Pengembangan SDM .........................................38

B. Strategi Pengembangan SDM Pada Perusahaan.........39

C. Tantangan BUMN Menata SDM Milenial.......................40 

D. Pengelolaan Manajemen Sumber Daya Manusia (SDM) Dalam Perusahaan
E. Pentingnya Manajemen Sumber Daya Manusia untuk Generasi Milenial
F. Keunggulan Kompetitif SDM Unggulan ...........................48
G. Keunggulan Kompetitif Berkelanjutan ..........................51
H. Strategi Pengembangan Sumber Daya Manusia..........55

BAB 5 KEARIFAN LOKAL................................................................66
A. Pengertian Kearifan Lokal 66
B. Tipe-Tipe Kearifan Lokal 68
C. Fungsi Kearifan Lokal 69
D. Contoh-contoh nyata Kearifan Lokal di dalam sebuah masyarakat 69
E. Tantangan Kearifan Lokal..................................................71
F. Pelayanan Kesehatan Berbasis Kearifan Lokal...........75
G. Pelayanan Kesehatan Berbasis Kearifan Lokal Melalui Pengobatan Tradisional ......................................79
H. Kearifan Lokal Masyarakat Di Dunia ...............................84

BAB 6 KEARIFAN LOKAL DAN TANTANGAN ZAMAN............99

A. Berfikir Global Bertindak Lokal..........................................101

BAB 7 KEARIFAN LOKAL DI INDONESIA …………………….....104

A. Definisi Kearifan Lokal .......................................................104

B. Kebudayaan Jawa .................................................................107

C. Kearifan Lokal Masyarakat Desa .....................................113

D. Gotong Royong Dalam Perspektif Kearifan Lokal ....130

BAB 8 RAGAM KEARIFAN LOKAL DI INDONESIA ....................132

A. Pengertian Kearifan Lokal ..................................................132

BAB 9 SINERGITAS PEMBANGUNAN

DI BALUTAN KEARIFAN LOKAL ……………………………….....136

A. Ragam Kearifan Lokal Di Indonesia ................................149

B. Manfaat Kearifan Lokal Dalam Konteks Pembangunan Di Indonesia 
BAB 10 KEBIJAKAN PELESTARIAN KEARIFAN LOKAL........160

A. Kearifan Lokal Dalam Mewujudkan Lingkungan Yang Produktif....................................................................160

BAB 11 MANFAAT KEARIFAN LOKAL

DALAM KONTEKS PEMBANGUNAN DI INDONESIA 164

A. Kearifan Lokal.....................................................................164

B. Kearifan Lokal sebagai Identitas dan Ideologi Bangsa ...........................................................................164

C. Kearifan Lokal: antara Pusaka dan Senjata...................167

D. Kebudayaan sebagai Pendorong Pembangunan Nasional 168

BAB 12 KEBIJAKAN PUBLIK DAN TANTANGAN GLOBALISASI 171

DAFTAR PUSTAKA. 184 



\section{BAB 1 \\ CAKRAWALA GLOBALISASI DAN PEMBANGUNAN}

\section{A. Pengertian dan Dampak Globalisasi}

Seiring perkembangan dunia, masyarakat perlu mengetahui pengertian globalisasi. Globalisasi merupakan kata serapan dari Globalization. Secara bahasa, global berarti mendunia, sedangkan ization yang merujuk kepada suatu proses. Menurut Kamus Besar Bahasa Indonesia, globalisasi berarti proses masuknya ke ruang lingkup dunia.

Sementara itu secara istilah, menurut ahli sosiologi Selo Soemardjan, globalisasi adalah suatu proses terbentuknya sistem organisasi dan komunikasi antar masyarakat di seluruh dunia, tujuannya untuk mengikuti sistem dan kaidah-kaidah tertentu yang sama.

Menurut Scholte globalisasi adalah berkembangnya hubungan internasional. Dalam hal ini setiap negara tetap mempertahankan identitas masing-masing, tetapi menjadi semakin ketergantungan satu dengan yang lain. Secara lebih ringkas, Globalisasi juga bisa diartikan sebagai fenomena saling terhubungnya negara di dunia salah satunya karena perkembangan teknologi sangat cepat.

Fenomena tersebut muncul karena berbagai faktor antara lain, perkembangan teknologi dan ilmu pengetahuan, perdagangan bebas, kemudahan orang-orang untuk bermigrasi dari negara satu ke negara lainnya, kerja sama politik antarnegara, hingga cara berpikir masyarakat yang semakin maju. Perkembangan teknologi membuat manusia semakin berpandangan luas tentang dunia. Contohnya, berkat media sosial, media komunikasi suara maupun video, media penyiaran, seseorang bisa mengetahui apa yang terjadi di belahan dunia lain meski jaraknya ratusan ribu kilometer sekalipun.

Orang-orang juga bisa mengunjungi negara lain secara langsung. Melihat budaya dan tradisi negara lain. Informasi juga berkembang pesat berkat media sosial yang mampu menghubungkan banyak orang dari berbagai kalangan, negara, dan latar belakang pendidikan. Meski demikian, 
globalisasi memberikan dampak positif sekaligus negatif pada kehidupan manusia.

\section{Dampak Positif Globalisasi}

1. Kehidupan menjadi lebih mudah karena kemajuan teknologi, komunikasi, transportasi dan informasi

2. Masyarakat bisa mendapatkan informasi dan ilmu pengetahuan lebih mudah dan cepat

3. Kehidupan sosial ekonomi yang meningkat.

\section{$>$ Dampak Negatif Globalisasi}

1. Semakin pudarnya nilai-nilai kebudayaan, misalnya musik lokal tradisional yang sepi peminat karena lebih tertarik dengan budaya lain yang lebih modern.

2. Mudahnya budaya barat masuk dan mempengaruhi nilainilai budaya lokal.

3. Lingkungan semakin rusak dan polusi udara meningkat

4. Rentan terjadi penyelundupan barang-barang illegal

\section{B. Karakteristik Globalisasi}

Globalisasi juga memiliki gejala-gejalanya. kita bisa membandingkan beberapa bidang dalam kehidupan sosial dari waktu ke waktu. Misal, dari bidang teknologi kita bisa melihat makin beragam dan makin canggihnya peralatanperalatan sekarang ini kan? kita jadi lebih gampang untuk melakukan kegiatan.

\section{Bentuk dan Gejala Globalisasi}

bentuk dan gejala globalisasi di berbagai bidang di kehidupan sosial. yang pertama bidang ekonomi, globalisasi ini erat dengan perdagangan bebas. Perdagangan bebas itu adalah sebuah sistem perdagangan yang semakin luas dan meniadakan hambatan yang ada pada proses perdagangan internasional. Biasanya hal ini ditandai dengan adanya organisasi internasional.

Kedua, bidang sosial, munculnya banyak penemuan baru pada akhirnya melipat jarak dan waktu yang ada. Kita bisa bertemu orang yang sangat jauh tanpa harus berpindah tempat. Hal yang dahulu sulit untuk dilakukan sekarang jadi mudah dilakukan dengan adanya alat telekomunikasi yang canggih. bentuk dari interaksi sosial mengalami perubahan pada saat ini. 
Ketiga, bidang budaya bisa kamu lihat dari bahasa. Kamu suka kan memakai bahasa Inggris? nah itu semua adalah salah satu contoh bahasa dunia, namun semua orang mempelajarinya karena yang menjadi bahasa internasional adalah bahasa Inggris. tak hanya bahasa Inggris, bahasa Rusia, Mandarin, Jepang, dan banyak bahasa lainnya kita pelajari sekarang ini. Itu semua karena ketika negara sudah menerima globalisasi, negara harus mengikuti arusnya.

Keempat, Politik. Kamu bisa melihat dari berbagai kebijakan nasional yang mempengaruhi keberadaan negara lain. Nah kita tahu juga kan adanya kebijakan tentang cukai, ekspor, atau impor. Kebijakan ini pasti mempengaruhi negara-negara lainnya lho. Ada banyak lagi bentuk dan gejala yang bisa diamati karena memang globalisasi merasuk ke dalam setiap hal di hidup kita.

Globalisasi pasti kita rasakan setiap harinya, dari bangun tidur sampai kita tidur. Globalisasi mengubah banyak sekali aspek kehidupan kita. Hal yang harus dilakukan oleh kita sekarang ini adalah mempersiapkan diri dari perubahanperubahan yang akan terjadi. Nah jadi kamu sudah mengerti apa itu globalisasi dan bagaimana globalisasi bisa terjadi?

\section{Proses Globalisasi}

Globalisasi tidak mendadak terjadi tentunya. Globalisasi ternyata tidak terjadi sekejap, Globalisasi terjadi dengan melalui banyak proses. Apa saja ya kira-kira prosesnya? Globalisasi muncul karena adanya perkembangan ilmu pengetahuan dan adanya akal yang dimiliki manusia membuat ilmu pengetahuan terus mengalami kemajuan.

Penemuan teori oleh seorang ilmuwan pada suatu masa akan disempurnakan oleh ilmuwan selanjutnya. Dengan akalnya maka manusia tak serta merta menerima teori dari ilmuwan sebelumnya. seiring waktu berjalan, ilmu pengetahuan pun jadi berkembang. Perkembangan ilmu pengetahuan adalah awal dari kemajuan teknologi informasi, teknologi komunikasi, dan teknologi transportasi.

Penemuan alat komunikasi misalnya yang semula begitu sederhana tak disangka kini semakin canggih sehingga proses komunikasi sangat cepat. Jika dulu kita hanya bisa mengirimkan pesan lewat SMS Short Message service yang terbatas jumlah kata yang dikirim dan harga pulsa yang relatif 
mahal, tak disangka sekarang kita bisa menggunakan aplikasi berbalas chat.

Bahkan jika semula hanya bisa berkirim pesan pada satu orang, kini kita berbagi pesan pada banyak orang langsung dengan adanya fasilitas grup yang disediakan. Jika dulu hanya suara saja yang bisa saling menyapa kini wujud nun jauh disana pun bisa terlihat lewat video call . Kemajuan teknologi akhirnya mendorong banyak inovasi di kehidupan sosial masyarakat. Jika jaman dahulu mau kemana-mana kita terkendala oleh transportasi, sekarang meskipun kita tak punya motor dan mobil sekalipun maka kota tinggal memesan transportasi online dimanapun kita berada, kemanapun tujuan kita.

\section{E. Globalisasi Dan Pembangunan Di Indonesia}

\section{Konsep Globalisasi}

Globalisasi merupakan satu proses untuk meletakkandunia di bawahsatuunityangsamatanpadibatasi oleh sempadandan kedudukan geografi di sebuah negara. Melalui proses ini, dunia akhirnya tidak lagi mempunyaisempadan dengan ruang udara dan langit. Sesebuah negara itu mempunyai peluang yang luas untuk menerima berbagai maklumat yang disalurkan menerusi sebagai perantaraan media komunikasi seperti internet, media elektronik dan teknologi siber. Perkembangan ini memudahkan manusia terutamanya dalam perhubungan yaitu di antara sebuah negara dengan negara yang lain ataupun perhubungan sesama manusia. Melalui perkembangan ini, sesuatu perhubungan itu dapat dilakukan dalam tempoyangsingkatdancepat.

Menurut Kamus Dewan, globalisasi dapat didefinisikan sebagai fenomena yang menjadikan dunia mengecil dari segi perhubungan manusia disebabkan oleh perkembangan teknologi maklumat. Manakala cendekiawan barat mentakrifkan globalisasi sebagai satu proses kehidupan yang sera luas dan infiniti merangkumi segala aspek kehidupan seperti politik, sosial ekonomi yang boleh di rasa oleh seluruh umat manusia di dunia ini. Ini bermakna segala-galanya menjadi memiliki bersama dalam konsep dunia tanpa sempadan.

Dalam era globalisasi ini, ruang dunia semakin mengecil dari hari ke hari. Jika dahulu dunia ini seluas sejauh mata memandang dan dipagari dengan sempadan-sempadan 
namun kini ia tidak berlaku lagi. Malah pada hari ini, kita merasakan apakah sebenarnya maksud dari globalisasi itu sendiri. Selain itu, ledakan teknologi maklumat yang kian pesat merupakan medium utama kepada perkembangan dan kepesatan globalisasi itu sendiri telah menjangkau sempadan ekonomi, teknologi, bahasa, budaya, ideologi, politik dan keseluruhan aspek kehidupan sebuah masyarakat.

\section{Pengertian Globalisasi}

John Huckle, globalisasi adalah suatu proses dengan mana kejadian, keputusan, dan kegiatan adalah satu bagian dunia menjadi suatu konsekuensi yang signifikan bagi individu dan masyarakat di daerah jauh.

Marthin Albrow, globalisasi adalah keseluruhan proses dimana manusia di bumi ini terinkorforasi (tergabung) ke dalam masyarakat dunia tinggal, masyarakat global.

Selo Soemarjan, globalisasi adalah terbentuknya suatu sistem organisasi dan komunikasi antar masyarakat di seluruh dunia untuk mengikuti sistem dan kaidah-kaidah yang sama. Jadi Globalisasi merupakan kecenderungan masyarakat di kota-kota untuk menyatu dengan dunia, terutama di bidang ilmu pengetahuan dan teknologi, pariwisata dan komunikasi.

Emmanuel Richter, globalisasi adalah jaringan kerjasama global yang secara bersamaan menyatukan masyarakat yang sebelumnya terpencar-pencar dan terisolasi dalam planet ini ke dalam ketergantungan yang saling menguntungkan dan persatuan dunia.

Robert Cox, karakteristik globalisasi adalah kecenderungan menyatunya internasionalisasi produksi, pembagian kerja internasional yang baru, perpindahan penduduk dari selatan ke utara lingkungan kompetitif baru yang mempercepat proses itu dan internasionalisasi negara, membuat negara sebagai agen globalisasi baru.

\section{Teori Globalisasi}

Teori globalisasi yang dianut para globalis percaya bahwa globalisasi adalah sebuah kenyataan yang memiliki konsekuensi nyata terhadap bagaimana orang dan lembaga di seluruh dunia berjalan. Mereka percaya bahwa negara-negara dan kebudayaan lokal akan hilang diterpa kebudayaan dan ekonomi global yang homogen. Meskipun demikian, para 
globalis tidak memiliki pendapat sama mengenai konsekuensi terhadap proses tersebut, Cochrane dan Pain menegaskan bahwa dalam kaitannya dengan globalisasi, terdapat posisi teoritis yang dapat dilihat, yaitu:

a. Para globalis positif dan optimistis menanggapi dengan baik perkembangan semacam itu dan menyatakan bahwa globalisasi akan menghasilkan masyarakat dunia yang toleran dan bertanggung jawab.

b. Para globalis pesimis berpendapat bahwa globalisasi adalah sebuah fenomenanegatif karena hal tersebut sebenarnya adalah bentuk penjajahan barat (terutamaAmerika Serikat) yang memaksa sejumlah bentuk budaya dan konsumsi yang homogeny dan terlihat sebagai sesuatu yang benar dipermukaan. Beberapa dari mereka kemudian membentuk kelompok untuk menentang globalisasi (anti globalisasi).

c. Para tradisionalis tidak percaya bahwa globalisasi tengah terjadi. Mereka berpendapat bahwa fenomena ini adalah sebuah mitos semata atau, jika memang ada,terlalu dibesarbesarkan. Mereka merujuk bahwa kapitalisme telah menjadi sebuahfenomena internasional selama ratusan tahun. Apa yang tengah kita alami saat ini hanyalah merupakan tahap lanjutan, atau evolusi, dari produksi dan perdagangan kapital.

d. Para transformasionalis berada di antara para globalis dan tradisionalis.Mereka setuju bahwa pengaruh globalisasi telah sangat dilebih-lebihkan oleh paraglobalis.

Namun, mereka juga berpendapat bahwa sangat bodoh jika kita menyangkal keberadaan konsep ini.Posisi teoritis ini berpendapat bahwa globalisasi seharusnya dipahami sebagai "seperangkat hubungan yang saling berkaitan dengan murni melalui sebuah kekuatan,yang sebagian besar tidak terjadi secara langsung". Mereka menyatakan bahwa proses ini bisa dibalik, terutama ketika hal tersebut negatif atau, setidaknya dapat dikendalikan.

\section{Analisis dan Kondisi Ideal}

Pengaruh globalisasi disatu sisi ternyata menimbulkan pengaruh yang negatif bagi kebudayaan bangsa. Norma-norma yang terkandung dalam kebudayaan suatu bangsa perlahanlahan akan pudar. Gencarnya serbuan teknologi disertai nilainilai interinsik yang diberlakukan di dalamnya, telah menimbulkan isu mengenai globalisasi dan pada akhirnya 
menimbulkan nilai baru tentang kesatuan dunia. Radhakrishnan dalam bukunya Eastern Religion and Western Though (1924) menyatakan "untuk pertama kalinya dalam sejarah umat manusia, kesadaran akan kesatuan dunia telah menghentakkan kita, entah suka atau tidak, Timur dan Barat telah menyatu dan tidak pernah lagi terpisah. Artinya adalah bahwa antara barat dan timur tidak ada lagi perbedaan. Atau dengan kata lain kebudayaan kita dilebur dengan kebudayaan asing.

Apabila timur dan barat bersatu, masihkah ada ciri khas kebudayaan kita? Ataukah kita larut dalam budaya bangsa lain tanpa meninggalkan sedikitpun sistem nilai kita? Oleh karena itu perlu dipertahanan aspek sosial budaya sebagai identitas bangsa. Caranya adalah dengan penyaringan budaya yang masuk ke dalam suatu negara dan pelestarian budaya bangsa. Bagi masyarakat yang mencoba mengembangkan seni tradisional menjadi bagian dari kehidupan modern, tentu akan terus berupaya memodifikasi bentuk-bentuk seni yang masih berpolakan masa lalu untuk dijadikan komoditi yang dapat dikonsumsi masyarakat modern. Karena sebenarnya seni itu indah dan mahal. Kesenian adalah kekayaan bangsa yang tidak ternilai harganya dan tidak dimiliki bangsa-bangsa asing. Oleh sebab itu, sebagai generasi muda, yang merupakan pewaris budaya bangsa, hendaknya memelihara seni budaya kita demi masa depan anak cucu.

\section{Kondisi sekarang di Indonesia}

Masyarakat Indonesia pada Era Globalisasi saat ini sangat buruk karena telah merambah masuk di semua sektor kehidupan bangsa Indonesia yang akhirnya akan berdampak pada budaya berfikir masyarakat Indonesia. Saat ini pola berfikir masyarakat Indonesia yang cenderung terpengaruh oleh budaya-budaya barat yang sebagian besar mencontoh pada perilaku negatif. Budaya tersebut tercermin dengan menjadikan budaya barat sebuah patron dari kemajuan peradaban berfikir manusia. Banyak saat ini generasi muda yang meniru pola kehidupan barat, dengan berbagai gaya dan perilakunya yang negatif dalam kehidupan sehari-hari.

Era globalisasi memang tidak bisa di kategorikan selalu membawa dampak yang negatif bagi kita, namun dalam hal ini eksistensi dari globalisasi tersebut lebih dominan kearah 
negatif, banyak contoh kasus yang dapat ditemukan yaitu: maraknya seks bebas dikalangan remaja yang saat ini dianggap bukan hal yang tabu lagi, perkembangan pornografi dengan kemajuan teknologi yang canggih banyak ditonton oleh anak dibawah umur dengan bebas dan mudah, tingkat penggunaan obat-obat terlarang yang sangat memprihatinkan. Indonesia sebagai negara dunia ketiga dijadikan pasar dari penjualan obat terlarang Internasional. Oleh karena itu kita perlu membangun kembali pondasi pola berfikir kita sebagai pengemban tugas berat penerus bangsa yang beradab sesuai dengan perilaku kita sebagai orang Indonesia.

\section{F. Dampak Globalisasi Terhadap Pembangunan}

\section{Dampak Globalisasi}

Globalisasi telah menimbulkan dampak yang sangat berarti dalam dimensi kehidupan manusia. Globalisasi merupakan proses internasionalisasi seluruh tatanan masyarakat modern. Pada awalnya ini hanya ada pada tataran ekonomi, namun dalam perkembangannya cenderung menunjukkan keragaman. Malcolm Waters mengemukakan bahwa ada 3 (tiga) dimensi proses globalisasi, yaitu: Globalisasi Ekonomi, Globalisasi Politik dan Globalisasi Budaya. Dari segi dimensi globalisasi budaya, muncul beberapa jenis space atau lukisan, seperti: emospace, technospace, finanspace, mediaspace, ideaspace dan sacrispace. Dengan demikian, universalisasi sistem nilai global yang terjadi dalam dimensi kebudayaan telah mengaburkan sistem nilai (values system) kehidupan manusia, khususnya pada negara-negara berkembang seperti Indonesia dalam menghadapi tahun era pasar bebas. Berikut adalah dampak globalisasi diberbagai bidang seperti berikut ini.

a. Ekonomi, yaitu terbentuknya masyarakat global yang tidak lagi tergantung batas batas wilayah. Dalam globalisasi bidang ekonomi telah terjadi perdagangan internasional pasar bebas, dibentuknya kerjasama regional, bilateral, maupun multilateral. Berdirinya organisasi World Bank, World Trade Organization, Asian Free Trade Area dan lainlain.

b. Ideologi, yaitu timbulnya dua ideologi besar yang menguasai dunia (Liberal dan Sosialis), di mana keduanya saling bertentangan. Ideologi Liberal menganut paham kebebasan 
untuk tiap individu merupakan jalan mencapai kebahagiaan, sementara ideologi Sosialis mengekang kebebasan rakyat untuk mencapai masyarakat yang makmur. Dengan globalisasi ideologi, berdampak luas terhadap upaya-upaya suatu negara dalam mewujudkan sistem politik, ekonomi maupun sosial budayanya.

c. Politik, yaitu pengaruh globalisasi pada sistem politik di berbagai negara yang berkembang seperti sistem politik demokrasi Liberal, demokrasi Pancasila, Sosialis, Komunis dan sebagainya.contoh di Indonesia, yaitu terjadinya dinamika ketatanegaraan sistem politik yang mula-mula berbentuk demokrasi liberal, kemudian menjadi demokrasi terpimpin dan akhirnya menjadi demokrasi pancasila yang dianut hingga sekarang ini.

d. Hankam, yaitu adanya upaya-upaya setiap negara dalam mempertahankan kedaulatan negaranya melalui pembuatan sistem persenjataan maupun pemberdayaan rakyat dan tentaranya. Globalisasi bidang hankam yang pernah dirasakan masyarakat dunia, yaitu dengan dibentuknya pakta pertahanan NATO, SEATO, WARSAWA, dan sebagainya. Dalam bidang hankam, negara Indonesia selain memperkuat berbagai sistem persenjataan di darat, udara dan laut juga melakukan upaya-upaya keamanan rakyat semesta dan kedaulatan nasional. Negara Indonesia dalam partisipasi menjaga keamanan internasional, juga pernah mengirim Pasukan Garuda kebeberapa negara atas mandat Dewan Keamanan PBB.

e. Sosial, yaitu banyaknya nilai-nilai dan budaya masyarakat yang mengalami perubahan dengan cara meniru atau menerapkannya secara selektif . Salah satu contoh perubahan di bidang sosial yaitu dengan hadirnya modernisasi di segala bidang kehidupan, terjadi perubahan ciri kehidupan masyarakat desa yang tadinya syarat dengan nilai-nilai gotong royong menjadi individual. Selain itu juga timbulnya sifat ingin serba mudah dan gampang (instan) pada diri seseorang. Pada sebagian masyarakat, juga sudah banyak yang mengikuti nilai-nilai budaya luar yang dapat berpengaruh negatif maupun positif.

Masyarakat dan bangsa Indonesia perlu mempersiapkan diri agar dapat memenangkan arus globalisasi ini. Tujuannya adalah mendapatkan segi-segi positif dari 
globalisasi dan mampu menghindarkan diri dari aspek negative globalisasi. Halhal yang perlu dipersiapkan adalah sebagai berikut:

a. Pembangunan kualitas manusia Indonesia melalui pendidikan.

b. Pemberian keterampilan hidup (life skill) agar mampu menciptakan kreativitas dan kemandirian.

c. Usaha menumbuhkan budaya dan sikap hidup global, seperti mandiri, kreatif, menghargai karya, optimis dan terbuka.

d. Usaha selalu menumbuhkan wawasan kebangsaan dan identitas nasional.

e. Usaha menciptakan pemerintahan yang transparan dan demokratis.

2. Pengaruh Globalisasi Terhadap Kehidupan Bangsa Dan Negara

\section{> Globalisasi di Bidang Ekonomi}

Abad 21, yang ditandai dengan globalisasi ekonomi. Hal ini merupakan suatu proses kegiatan ekonomi dan perdagangan, di mana negara-negara di seluruh dunia menjadi satu kekuatan pasar yang semakin terintegrasi dengan tanpa rintangan batas teritorial negara.

Kekuatan ekonomi global menyebabkan bisnis korporasi, termasuk BUMN, perlu melakukan tinjauan ulang terhadap struktur dan strategi usaha serta melandaskan strategi manajemennya dengan basis entrepreneurship, cost efficiency dan competitive advantages. Mencermati kondisi Indonesia dalam konteks ekonomi global, Sjahrir (2001) mengemukakan bahwa, suasana internal dan eksternal ekonomi Indonesia pada saat ini menunjukkan fenomena yang kurang menggembirakan. Untuk itu Bangsa Indonesia perlu melakukan prioritas dalam memulihkan ekonomi. Jika hal ini tidak segera dilakukan, maka akan menimbulkan berbagai kosekuensi serius, antara lain:

a. Semakin meningkatnya harga barang (tingkat inflasi yang tinggi),

b. Jumlah pengangguran yang semakin membengkak (apalagi pengangguran yang terjadi pada kaum intelektual),

c. Kemiskinan struktural yang semakin memilukan,

d. Utang yang semakin menggunung baik pada pihak luar negeri maupun dalam negeri dan 
e. Pertumbuhan ekonomi yang semakin rendah.

\section{Perdebatan dalam Globalisasi}

Dalam topik ini, ada empat hal yang menjadi esensi pembahasan yaitu mengenai apakah debat besar globalisasi, apa yang diperdebatkan, siapa yang terlibat dalam perdebatan globalisasi serta apa pengaruhnya terhadap perkembangan studi globalisasi itu sendiri. Menurut David Held (1999), debat besar globalisasi adalah intensifikasi nyata dari keterkaitan global mengenai ketidaksepakatan substansial tentang bagaimana globalisasi seharusnya dikonseptualisasikan, bagaimana berpikir tentang dinamika kausal serta bagaimana orang harus mencirikan strukturnya bila ada.

Pada dasarnya, debat Globalisasi mempertanyakan tentang bagaimana perubahannya, sumber-sumber perubahan, nasib perbedaan nasional, menanggapi perubahan global dan masa depan politik dalam negeri (Daves dalam Susanto 2014). Banyak para ilmuwan yng memiliki pandangan berbeda-beda terhadap apa, kapan, di mana, siapa, mengapa dan bagaimanakah globalisasi itu. Hal inilah yang kemudian memunculkan perdebatan globalisasi yang membagi dua kelompok perdebatan besar yaitu kalangan akademisi dan kalangan dari khalayak umum (Steger, 2002: 18). Tidak berbeda jauh dengan hal tersebut, bahwasanya yang menjadi perdebatan adalah tentang konsep, penyebab, akibat, periode, dan alur dari globalisasi yang melibatkan kelompok dan transformationalists.

hyperglobalizers,

sceptics,

Menurut kaum hiperglobalis, struktur dunia saat ini sudah berubah yang bisa dilihat dari adanya peningkatan ekonomi global, institusi pemerintahan global, dan juga pembauran budaya dalam masyarakat (Luard 1990 dalam Held et al., 1999: 5). Globalisasi dianggap sebagai peristiwa ekonomi karena semakin terintegrasinya perekonomian di dunia. Di sisi lain, dalam pandangannya, kaum skeptis memandang perdagangan regional telah menjadi pola perdagangan saat ini. Akan tetapi, regionalisasi yang semakin terpusat akan menyebabkan negara-negara di dunia ketiga semakin termarjinalisasi, bukan mengurangi kesenjangan antara Utara yang kaya dan Selatan yang miskin (Hirst \& Thompson 1996 dalam Held et al., 1999: 6). Sedangkan kaum 
transformasionalis menganggap bahwa globalisasi sama dengan pola baru dari stratifikasi global, dimana negara, masyarakat, dan komunitas terus menerus menjadi terperangkap dalam tatanan global sementara lainnya termajinalkan (Held et al., 1999: 8). Bagi mereka modernitaslah faktor pendorong globalisasi, sehingga dunia global saling terhubung. Beberapa hal yang menjadi ciri dari perspektif transformasionalis adalah pandangan terhadap lahirnya globalisasi yang ditandai dengan adanya keterkaitan yang bersifat global dan globalisasi dirasa mampu menyebabkan rekonstitusi dan restrukturasi kekuatan pemerintahan nasional serta dunia politik (Held et al., 1999).

Isu-isu yang disebutkan tersebut adalah apa yang diperdebatkan dalam debat besar globalisasi. Sederhananya, perdebatan ini hanya mengerucut pada hal-hal seperti latarbelakang sejarah, agen pembawanya, bidang apakah globalisasi dan trajektori. Pada akhirnya, globalisasi terbagi menjadi tiga jenis setelah melalui sebuah dinamika debat. Dalam dinamika debat ada tahapan-tahapan pertanyaan yang dapat membuat debat tersebut dijabarkan dalam kontemporaris, historisis dan modernis (Susanto, 2014) Kontemporaris lebih condong ke dalam industri, yang dilatarbelakangi oleh revolusi informasi. Dengan agennya adalah masyarakat, membawa dampak yang akan ditimbulkan yaitu sebuah masyarakat informasi global (Susanto, 2014). Sedangkan historisis yang terfokus pada masa lalu lebih condong di bidang kapitalisme dan pasar, Menjelaskan isu-isu globalisasi cenderung pada isu-isu ekonomi dan dominasi pasar. Pada akhirnya dengan pesimistis mereka menganggap globalisasi adalah imperialisme model baru (Susanto, 2014). Di pihak lain para modernis mengungkapkan globalisasi membawa manusia menjadi lebih modern. Tingkat dimana masyarakat dunia dapat merasakan hangatnya politik luar negeri, dari situ dapat tercipta demokrasi global yang selalu modernis dambakan (Susanto, 2014). Salah satu hal yang menjadi perbincangan dalam debat besar globalisasi adalah penyebab terjadinya globalisasi itu sendiri. Tiga penyebab utama yang mendorong globalisasi adalah teknologi, politik, dan ekonomi (Daves, 2000: 113). Teknologi telah membantu meningkatkan pemasukan dari sektor ekonomi dan sekaligus menjadikannya bagian dari kegiatan ekonomi global. Setelah 
memahami apa dan seperti apa debat besar globalisasi maka tentunya debat besar globalisasi tersebut memberikan pengaruh terhadap perkembangan studi Globalisasi.

Pertama, debat besar globalisasi menjadi suatu wadah pemikiran teoritis yang berbeda-beda dan pemahaman mendalam mengenai globalisasi yang kemudian memunculkan beragam interpretasi terhadap globalisasi tersebut. Dari hal inilah yang menyebabkan debat besar menjadi satu hal yang penting sebagai fondasi awal pemahaman bagi pembelajarannya.

Kedua, debat besar ini telah memberikan kontribusi terhadap eksistensi studi Globalisasi. Mengingat suatu studi akan terus berkembang, maka ilmu tersebut akan terus dikaji oleh berbagai ilmuwan maupun para pemikir. Hal tersebut ditujukan agar studi Globalisasi terus memperbaharui dan mencari nilai kebenaran sehingga relevan untuk digunakan mengkaji fenomena masa sekarang maupun di masa yang akan mendatang. Ketiga, debat besar globalisasi membiarkan para ilmuwan serta pembelajarannya untuk berpendapat di luar batasan-batasan ilmu politik dan sebagainya (Keohane dan Milner dalam Daves, 2000: 120).

Hal inilah yang kemudian membuat globalisasi dapat dipandang dengan bermacam-macam sudut pandang. Dalam hal ini kelompok sebelas mengatakan bahwa adanya debat besar globalisasi mampu memberikan gambaran bagi para penstudi globalisasi bahwa dampak yang diberikan oleh adanya globalisasi semakin beragam. Dengan adanya debat besar globalisasi, penstudi dapat memahami bahwa globalisasi bukan hanya tentang modernisasi. Selain itu, menurut Rosenau (1997 dalam Held et al., 1999: 14), akibat globalisasi dunia akan terlihat semakin lebar namun tidak tentu dan tidak pasti.

Dari penjelasan tersebut dapat disimpulkan bahwa debat besar globalisasi secara sederhana merupakan suatu wadah bagi berbagai pemikiran teoritis yang berbeda-beda terkait dengan globalisasi. Hal yang menjadi perdebatannya adalah apa, kapan, di mana, siapa, mengapa dan bagaimanakah globalisasi itu. Namun disamping itu debat Globalisasi juga mempertanyakan tentang bagaimana perubahannya, sumber-sumber perubahan, nasib perbedaan nasional, menanggapi perubahan global dan masa depan 
politik dalam negeri. Dari pemaparan di atas kita juga dapat mengetahui bahwa ada tiga kelompok besar yang terlibat dalam debat besar globalisasi yaitu hyperglobalizers, sceptics, dan transformationalists yang masing-masing memiliki perspektif masing-masing.

Proses debat besar globalisasi tersebut memberikan pengaruh terhadap perkembangan studi Globalisasi. Debat besar itu pada dasarnya turut memperkaya studi Globalisasi serta memberi kontribusi terhadap eksistensi studi Globalisasi sehingga relevan untuk digunakan mengkaji fenomena-fenomena masa sekarang maupun di masa yang akan mendatang. Akan tetapi dari hasil diskusi pada pertemuan ini, ketiga kelompok presenter belum memaparkan secara jelas apa yang menjadi momentum awal munculnya globalisasi. Selain itu, menurut penulis, ketiga kelompok tersebut kurang memberikan garis yang jelas atau esensi terhadap apa yang menjadi perdebatan dalam debat besar globalisasi.

Dalam proses diskusi, kelompok tujuh mengatakan bahwa salah satu dampak yang ditimbulkan dari globalisasi adalah pembagian sistem kelas dunia menjadi tiga yaitu core, semi periphery, dan periphery yang memberikan keuntungan bagi semua serta dapat membantu memenuhi kebutuhan jangka pendek. Namun penulis kurang setuju dengan hal tersebut, karena pada dasarnya dengan adanya sistem kelas dunia semacam itu bukannya memberikan keuntungan tetapi menyebabkan adanya ketimpangan antar negara yang mana negara yang kaya bisa saja mengintimidasi dan mengeksploitasi negara yang miskin dalam hubungan kerja sama yang dijalinnya sehingga hal ini kemudian menumbuhkan adanya imperialisme.

\section{G. Pembangunan Berkelanjutan}

Pembangunan berkelanjutan adalah proses pembangunan (lahan, kota, bisnis, masyarakat, dsb) yang berprinsip "memenuhi kebutuhan sekarang tanpa mengorbankan pemenuhan kebutuhan generasi masa depan" (menurut Laporan Brundtland dari PBB, 1987). Pembangunan berkelanjutan adalah terjemahan dari Bahasa Inggris, sustainable development. 
Salah satu faktor yang harus dihadapi untuk mencapai pembangunan berkelanjutan adalah bagaimana memperbaiki kehancuran lingkungan tanpa mengorbankan kebutuhan pembangunan ekonomi dan keadilan sosial.

Pembangunan berkelanjutan tidak saja berkonsentrasi pada isu-isu lingkungan. Lebih luas daripada itu, pembangunan berkelanjutan mencakup tiga lingkup kebijakan: pembangunan

ekonomi, pembangunan sosial dan perlindungan lingkungan. Dokumen-dokumen PBB, terutama dokumen hasil World Summit 2005 menyebut ketiga hal dimensi tersebut saling terkait dan merupakan pilar pendorong bagi pembangunan berkelanjutan.

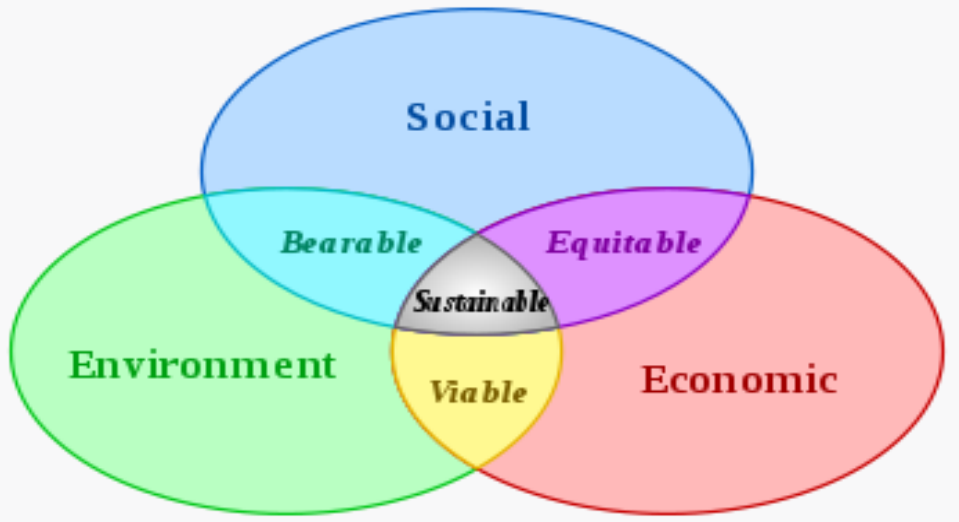

Scheme of sustainable development: at the confluence of three preoccupations.

Skema pembangunan berkelanjutan pada titik temu tiga pilar tersebut, Deklarasi Universal Keberagaman Budaya (UNESCO, 2001) lebih jauh menggali konsep pembangunan berkelanjutan dengan menyebutkan bahwa ". keragaman budaya penting bagi manusia sebagaimana pentingnya keragaman hayati bagi alam". Dengan demikian "pembangunan tidak hanya dipahami sebagai pembangunan ekonomi, namun juga sebagai alat untuk mencapai kepuasan intelektual, emosional, moral, dan spiritual". dalam pandangan ini, keragaman budaya merupakan kebijakan keempat dari lingkup kebijakan pembangunan berkelanjutan.

Pembangunan Hijau pada umumnya dibedakan dari pembangunan bekelanjutan, di mana pembangunan Hijau lebih mengutamakan keberlanjutan lingkungan di atas pertimbangan ekonomi dan budaya. Pendukung 
Pembangunan Berkelanjutan berargumen bahwa konsep ini menyediakan konteks bagi keberlanjutan menyeluruh di mana pemikiran mutakhir dari Pembangunan Hijau sulit diwujudkan. Sebagai contoh, pembangunan pabrik dengan teknologi pengolahan limbah mutakhir yang membutuhkan biaya perawatan tinggi sulit untuk dapat berkelanjutan di wilayah dengan sumber daya keuangan yang terbatas.

Beberapa riset memulai dari definisi ini untuk berargumen bahwa lingkungan merupakan kombinasi dari alam dan budaya. Network of Excellence "Sustainable Development in a Diverse World" SUS.DIV, sponsored by the European Union, bekerja pada jalur ini. Mereka mengintegrasikan kapasitas multidisiplin dan menerjemahkan keragaman budaya sebagai kunci pokok strategi baru bagi pembangunan berkelanjutan.

Beberapa peneliti lain melihat tantangan sosial dan lingkungan sebagai kesempatan bagi kegiatan pembangunan. Hal ini nyata di dalam konsep keberlanjutan usaha yang mengkerangkai kebutuhan global ini sebagai kesempatan bagi perusahaan privat untuk menyediakan solusi inovatif dan kewirausahaan. Pandangan ini sekarang diajarkan pada beberapa sekolah bisnis yang salah satunya dilakukan di Center for Sustainable Global Enterprise at Cornell University.

Pembangunan berkelanjutan merupakan konsep yang ambigu, di mana pandangan yang luas berada di bawah naungannya. konsep ini memasukkan pemahaman keberlanjutan lemah, keberlanjutan kuat, dan ekolog mendalam. konsep yang berbeda juga menunjukkan tarik ulur yang kuat antara eko(lingkungan)sentrisme dan antropo(manusia)sentrisme. Oleh karena itu konsep ini lemah didefinisikan dan mengundang debat panjang mengenai definisinya.

Selama sepuluh tahun terakhir, lembaga-lembaga yang berbeda telah berusaha mengukur dan memantau perkiraan atas apa yang mereka pahami sebagai keberlanjutan dengan mengimplementasikan apa yang disebut dengan matrik dan indikator keberlanjutan.

\section{$\checkmark$ Peran Penduduk dalam Pembangunan Berkelanjutan}

Penduduk atau masyarakat merupakan bagian penting atau titik sentral dalam pembangunan berkelanjutan, 
karena peran penduduk sejatinya adalah sebagai subjek dan objek dari pembangunan berkelanjutan. Jumlah penduduk yang besar dengan pertumbuhan yang cepat, namun memiliki kualitas yang rendah, akan memperlambat tercapainya kondisi yang ideal antara kuantitas dan kualitas penduduk dengan daya dukung alam dan daya tampung lingkungan yang semakin terbatas.

\section{$\checkmark$ Penduduk Berkualitas ialah Modal Utama Pembangunan Berkelanjutan}

Untuk mewujudkan pembangunan berkelanjutan di suatu Negara, diperlukan komponen penduduk yang berkualitas. Karena dari penduduk berkualitas itulah memungkinkan untuk bisa mengolah dan mengelola potensi sumber daya alam dengan baik, tepat, efisien, dan maksimal, dengan tetap menjaga kelestarian lingkungan. Sehingga harapannya terjadi keseimbangan dan keserasian antara jumlah penduduk dengan kapasitas dari daya dukung alam dan daya tamping lingkungan.

\section{H. Partisipasi Masyarakat Dalam Pembangunan}

\section{Pengertian Partisipasi Masyarakat}

Partisipasi dalam Kamus Bahasa Indonesia adalah ikut serta dalam suatu kegiatan. Sedangkan masyarakat adalah eksistensi yang hidup, dinamis dan selalu berkembang. \{Hery Noer Aly dan Munzier Suparta, 2003 : 191\}. Kata partisipasi masyarakat dalam pembangunan menunjukkan pengertian pada keikutsertaan mereka dalam perencanaan, pelaksanaan, pemanfaatan hasil dan evaluasi program pembangunan \{ United Nation : 175 \}. Dalam kebijakan nasional kenegaraan ini, meelibatkan masyarakat dalam kegiatan pembangunan adalah merupakan konsekuensi logis dari implementasi Undang-Undang No 22 Tahun 1990 Tentang Pemerintahan Daerah.

Partisipasi masyarakat dalam pembangunan pada umumnya dimulai dari tahap pembuatan keputusan, penerapan keputusan, penikmatan hasil dan evaluasi kegiatan \{Cohen dan Uphoff : 1980 \}. Secara lebih rinci, partisipasi dalam pembangunan berarti mengambil bagian atau peran dalam pembangunan, baik dalam bentuk pernyataan mengikuti kegiatan, memberi masukan berupa pemikiran, 
tenaga, waktu, keahlian, modal dana atau materi serta ikut memanfaatkan dan menikmati hasilnya \{ Sahidu : 1998\}.

Selama ini, penyelenggaraan partisipasi masyarakat di Indonesia dalam kenyataannya masih terbatas pada keikutsertaan anggota masyarakat dalam implementasi atau penerapan program-program pembangunan saja. Kegiatan partisipasi masyarakat masih lebih dipahamiu sebagai mobilisasi untuk kepentingan pemerintah atau Negara.

Dalam implementasi partisipasi masyarakat, seharusnya anggota masyarakat merasa bahwa tidak hanya menjadi objek kebijakan dari pemerintah, tetapi harus dapat mewakili masyarakat itu sendiri sesuai dengan kepentingan mereka. Perwujudan partisipasi masyarakat dapat dilakukan, baik secara individu atau kelompok, bersifat spontan atau terorganisasi, secara berkelanjutan atau sesaat, serta dengan cara-cara tertentu yang dapat dilakukan.

Partisipasi adalah proses aktif dan inisiatif yang muncul dari masyarakat serta akan terwujud sebagai suatu kegiatan nyata apabila terpenuhi oleh 3 faktor pendukungnya yaitu : adanya kemauan, kemampuan dan kesempatan untuk berpartisipasi \{ Slamet : 1992 \}.

Kemauan dan kemampuan berpartisipasi berasal dari yang bersangkutan \{ warga atau kelompok masyarakat \}, sedangkan kesempatan berpartisipasi dating dari pihak luar yang memberikan peluang. Apabila ada kemauan tetapi tidak ada kemampuan dari warga atu kelompok masyarakat, meskipun pemerintah juga telah memberikan peluang, maka partisipasipun juga tidak akan terjadi. Demikian juga, jika ada kemauan dan kemampuan tetapi tidak adanya ruang atau kesempatan yang diberikan oleh pemerintah untuk wrga atau kelompok masyarakat, maka partisipasipun juga tidak akan terjadi.

Demikian halnya dengan partisipasi masyarakat dalam pengembangan pendidikan Indonesia, perlu ditumbuhkan adanya kemauan dan kemampuan warga atau kelompok masyarakat untuk berpartisipasi dalam pengembangan pendidikan . Sebaliknya pihak pemerintah atau Negara juga memberikan ruang atau kesempatan kepada warga atau kelompok masyarakat untuk berpartispasi seluas mungkin sehingga kita bisa mencetuskan sebuah ide yang kreatif dan imajinatif dalam pengembangan pendidikan, 
seperti pepatah orang jawa " Rawe-rawe rantas, malangmalang putung" atau dalam Bahasa indonesianya "Bercerai kita runtuh, Bersatu kita teguh".

Agar kemampuan untuk berpartisipasi masyarakat dimiliki oleh masyarakat, maka perlu peningkatan SDM manusia dengan cara memperbaharui 3 jenis pendidikan masyarakat baik formal, nonformal maupun informal. Akses yang luas terhadap 3 jenis pendidikan tewrsebut akan mempercepat laju tingginya tingkat pendidikan dan pada gilirannya akan membuat masyarakat mampu untuk ikut serta dalam pengembangan pendidikan.

\section{Pengembangan Pendidikan di Indonesia}

Secara singkat pendidikan merupakan produk dari masyarakat. Pendidikan tidak lain merupakan proses tranmisi pengetahuan, sikap, kepercayaan, ketrampilan dan aspek perilaku-perilaku lainnya kepada generasi kegenerasi. Dengan pengertian tersebut, sebenarnya upaya diatas sudah dilakukan sepenuhnya oleh kekuatan-kekuatan masyarakat. Hampir segala sesuatu yang kita pelajari adalah hasil dari hubungan kita dengan orang lain, baik dirumah, sekolah, tempat bermain, pekerjaan dan lainnya. Dengan kata lain dimanapun kita berada kita pasti akan belajar dan mendapatkan ilmu pengetahuan.

Bagi suatu masyarakat, hakikat pendidikan diharapkan mampu berfungsi menunjang kelangsungan kemajuan hidupnya, agar masyarakat itu dapat melanjutkan eksistensinya, maka diteruskan nilai-nilai, pengetahuan, ketrampilan dan bentuk tata perilaku lainnya bagi generasi muda. Tiap masyarakat selalu berupaya meneruskan kebudayaannya dengan proses adaptasi tertentu sesuai coraknya masing-masing periode zamannya kepada generasi muda melalui pendidikan atau secara khusu melalui interaksi social. Dengan demikian fungsi pendidikan tidak lain adalah sebagai proses sosialisai.

Dalam pengertian sosialisasi tersebut, dapat disimpulkan bahwa aktifitas pendidikan sebenarnya sudah dimulai sejak ia dilahirkan kedunia yaitu keluarga. Didalam keluargalah anak pertama menerima pendidikan dan pendidikan yang diperoleh dalam keluarga ini merupakan pendidikan utama atau terpenting terhadap perkembangan pribadi anak. Pada didalam kehidupan keluarga memberi 
corak pola kepribadian anak yang hidup di dalam keluarga. Alam keluarga adalah pusat pendidikan yang pertama sejak timbulnya adapt kemanusiaan hingga sekarang, hidup keluarga itu selalu mempengaruhi bertumbuhnya budi pekerti dari tiap-tiap manusia.

Akan tetapi tidak dapat dipungkiri pula ternyata masyarakat dunia secara global telah ikut mempengaruhi iklim pendidikan. Pengaruh modernisasi di berbagai sektor kehidupan telah melahirkan karakter pendidikan yang hampir sama di seluruh dunia, memiliki mempunyai ciri khas tertentu di tiap- tiap Negara. Dalam masyarakat yang sudah maju, proses pendidikan sebagian dilaksanakan dalam lembaga pendidikan yang disebut sekolah dan pendidikan dalam lembaga tersebut merupakan suatu kegiatan yang lebih teratur dan terdeferensiasi. Inilah pendidikan formal yang biasa dikenal oleh masyarakat sebagai"Schooling.

Perkembangan teknologi dan informasi menyebabkan peranan sekolah sebagai lembaga pendidikan akan mulai tergeser. Sekolah tidak lagi menjadi satu-satunya pusat pembelajaran karena aktivitas belajar tidak lagi terbatasi oleh ruang dan waktu. Peran guru tidak akan menjadi satu-satunya sumber belajar karena banyak sumber belajar dan informasi yang mampu memfasilitasi orang untuk belajar. Oleh karena itu aktualisasi partisipasi masyarakat dalam pengembangan pendidikan sangat diperlukan.

\section{Aktualisasi Masyarakat Dalam Pengembangan Pendidikan}

Bentuk aktualisasi dan pernyataan penyadaran diri masyarakat secara kolektif dapat berupa partisipasinya dalam proses pengambilan keputusan yang berhubungan dengan kebutuhan dirinya dan kelompoknya dalam komunitas yang melingkupinya. Cara-cara kolektif berpartisipasi dalam bermasyarakat bisa teraktualisasikan dalam bentuk musyawarah dan juga terbentuknya institusi lokal oleh masyarakat itu sendiri.

Musyawarah adalah sebuah pendekatan kultural khas Indonesia yang dapat dimasukkan dalam proses ekplorasi kebutuhan dan identifikasi masalah. Musyawarah juga merupakan bentuk sarana untuk meningkatkan rasa partisipasi dan rasa memiliki atas keputusan dan rencana pembangunan. Musyawarah dapat merupakan cara analisis 
kebutuhan dan tidak sekedar keinginan yang bersifat superfisial demi pemenuhan kebutuhan sesaat. Oleh karena itu pemilihan orang-orang yang mewakili sebagai peserta musyawarah untuk suatu keperluan seperti merumuskan kebutuhan masyarakat haruslah benar-benar yang mampu menyalurkan aspirasi masyarakat yang diwakilinya.

Langkah lain dalam proses partisipasi masyarakat itu adalah pembentukan kelompok. Melalui kelompok akan dibina solidaritas kerjasama, musyawarah, rasa aman dan percaya kepada diri sendiri. Salah satu cara yang efektif untuk membentuk kelompok adalah melalui pendekatan kepentingan yang sama secara primordial. Dalam kelompok primordial itu, para anggota kelompok akan memperoleh referensi yang sama, Dengan bertolakbelakang dari kelompok primordial, maka para anggota akan merasakan adanya halhal baru jika mereka bersedia membandingkannya dengan situasi lama. Ini akan menimbulkan keasyikan dan motivasi sendiri. Melalui kelompok, para anggota akan menyusun program, bekerja secara sistematis serta bisa merasakan adanya perkemabangan dan kemajuan sebagai hasil kegiatan mereka.

Pada dasarnya, partisipasi masyarakat telah terjadi di sekolah dalam praktik penyelenggaraan musyawarah maupun pembentukan institusi lokal. 2 jenis kebijakan pemerintah tentang MBS disekolah-sekolah tingkat dasar dan menengah serta Majelis Wali Amanah di perguruan tinggi BHMN adalah contoh dari bentuk perwujudan mekanisme dan struktur kelembagaan untuk menyalurkan partisipasi masyarakat dalam pengembangan pendidikan.

Cara untuk penyaluran partisipasi dapat diciptakan dengan berbagai variasi cara sesuai dengan kondisi masingmasing wilayah atau tempat komunitas masyarakat dan lembaga pendidikan itu berada. Kondisi ini menuntut kesiapan para pemegang kebijakan dan manajer pendidikan untuk mendistribusi peran dan kekuasaannya agar bisa menampung sumbangan partisipasi masyarakat. Sebaliknya dari pihak masyarakat juga harus belajar untuk kemudian bisa memiliki kemauan dan kemampuan berpartisipasi dalam pengembangan pendidikan.

Sebagai contoh adalah tanggungjawab dunia usaha/ industri. Mereka tidak bisa tinggal diam menunggu dari suatu 
lembaga pendidikan/ sekolah sampai dapat meluluskan alumninya, lalu menggunakannya jika menghasilkan output yang baik dan mengkritiknya jika terdapat output yang tidak baik. Partisipasi dunia usaha/ industri terhadap lembaga pendidikan harus ikut bertanggungjawab untuk menghasilkan output yang baik sesuai dengan rumusan harapan bersama. Demukian juga kelompok masyarakat lain, termasuk orangtua siswa. Dengan cara demikian, maka mutu pendidikan dalam suatu lembaga pendidikan menjadi tanggungjawab bersama antara lembaga pendidikan dan komponen-komponen lainnya dimasyarakat.

Uraian diatas bukan bermaksud untuk mengurangi tanggungjawab pemerintah sebagai penyelenggara Negara dalam bidang pendidikan. Sebagaimana diamanatkan oleh UU Sisdiknas 2003 bahwa pemerintah dan pemerintah daerah juga berhak mengarahkan, membimbing, membantu dan mengawasi penyelenggaraan pendidikan serta berkewajiban memberikan layanan dan kemudahan penyelenggaraan pendidikan yang bermutu bagi setiap warga Negara tanpa diskriminasi. Pemerintah dan pemerinmtahan daerah juga wajib menjamin tersedianya dana guna terselenggaranya pendidikan bagi setaip warga Negara dari usia 7-15 tahun. Lebih dari itu, sebenarnya peluang bagi orang tua / warga dan kelompok masyarakat masih sangatlah luas.

Untuk itu , maka dalam kondisi kualitas layanan dan output pendidikan sedang banyak dipertanyakan mutu dan relevansinya, maka pemerintah seharusnya memberikan peluang yang luas bagi partisipasi masyarakat. Sebagaimana yang dikemukakan oleh Suryadi Prawirosentono $\{2002: 12\}$ bahwa ada 6 hal yang bisa mempengaruhi produk dan salah satunya adalah SDM. SDM kita ibaratkan sebagai kelompok masyarakat, yang mana bisa membawa pengaruh pendidikan yang ada dalam sebuah Negara. Lebih dari itu, pemerintah perlu menyusun mekanisme sehingga orang tua dan kelompok-kelompok masyarakat dapat berpartisipasi secara optimal dalam pengembangan pendidikan di Indonesia. 


\section{BAB 2 \\ SDM DAN PENGUATAN PEMBANGUNAN}

\section{A. Pengertian Manajemen Sumber Daya Manusia ( MSDM )}

Manajemen sumber daya manusia (MSDM) merupakan salah satu bidang dari manajemen umum yang meliputi segi-segi perencanaan, pengorganisasian, pelaksanaan, dan pengendalian. Proses ini terdapat dalam bidang /fungsi produksi, pemasaran, keuangan, ataupun kepegawaian. Karena sumberdaya manusia(SDM) diangggap semakin penting perannya dalam pencapaian tujuan perusahaan, maka berbagai pengalaman dan hasil penelitian dalam bidang SDM dikumpulkan secara sistematis dalam apa yang di sebut manajemen sumber daya manusia. Istilah “ manajemen mempunyai arti sebagai pengetahuan tentang bagaimana seharusnya memanage (mengelola) sumber daya manusia.

Dalam usaha pencapaian tujuan perusahaan, permasalahan yang dihadapi manajemen bukan hanya terdapat hanya pada bahan mentah, alat-alat kerja, mesinmesin produksi, uang dan lingkungan kerja saja, tetapi juga menyangkut karyawan (sumber daya manusia) yang mengelola factor produksi lainnya tersebut. Namun, perlu di ingat bahwa sumber daya manusia manusia sendiri sebagai faktor produksi, seperti halnya factor produksi yang lainnya, merupakan masukan (input) yang diolah oleh perusahaan dan menghasilkan keluaran (output). Karyawan baru yang belum memilii keterampilan dan keahlian dilatih, sehingga menjadi karyawan yang terampil dan ahli. Apabila dia dilatih lebih lanjut serta diberikan pengalaman dan motivasi, dia akan menjadi karyawan yang matang. Pengolahan sumber daya manusia inilah yang disebut Manajemen SDM.

\section{B. Pentingnya SDM yang Berkualitas Dalam suatu Pembangunan Nasional maupun Daerah}

Dalam suatu organisasi, sumber daya manusia bukan hanya sebagai alat dalam produksi tetapi memiliki peran penting dalam kegiatan produksi suatu organisasi. Kedudukan SDM saat ini bukan hanya sebagai alat produksi tetapi juga 
sebagai penggerak dan penentu berlangsungnya proses produksi dan segala aktivitas organisasi. SDM memiliki andil besar dalam menentukan maju atau berkembangnya sutau organisasi. Oleh karena itu, kemajuan suatu organisasi ditentukan pula bagaimana kualitas dan kapabilitas SDM di dalamnya.

Organisasi yang dimaksud tidak terkecuali organisasi pemerintahan. Baik pemerintah pusat maupun pemerintah daerah sama-sama memerlukan SDM yang berkualitas dan memiliki kapabilitas dalam memberikan pelayanan kepada masyarakat dan memajukan daerahnya dengan meningkatkan daya saing daerah. Dalam upaya meningkatkan kualitas pelayanan publik dan menigkatkan daya saing daerah, diperlukan SDM yang mampu memahami bagaimana menciptakan metode pelayanan yang maksimal sehingga dicapai pelayanan yang prima bagi masyarakat dan mampu melihat potensi yang dimiliki daerah kemudian menciptakan inovasi dalam memanfaatkan potensi daerah.

Di era otonomi daerah, dimana kewenangan terhadap penyelenggaraan urusan pemerintahan terutama pelayanan masyarakat yang sudah diberikan kepada daerah menuntut masing-masing daerah berlomba-lomba memperbaiki sistem pelayanan publik di tingkat daerah. Perbaikan pelayanan publik tersebut akan terwujud apabila ada political will dari pimpinan yang didukung oleh bawahan atau para pegawai daerah ataupun sebaliknya, kesadaran itu muncul dari bawahan yang kemudian diakomodasi dan didukung oleh atasan. Begitu juga dalam hal peningkatan daya saing daerah, membutuhkan SDM-SDM yang memiliki kemampuan dalam menggali dan memanfaatkan potensi daerah sehingga apa yang dimiliki daerah dapat dirasakan manfaatnya oleh masyarakat daerah.

Dalam hal ini posisi kepala daerah turut menentukan bagus tidaknya pelayanan publik yang diberikan di daerahnya. Tidak dapat dipungkiri, peran kepala daerah dalam menentukan arah pembangunan daerah sangat besar. Apabila tidak ada political will dari pimpinan, usaha-usaha perbaikan tidak dapat dilakukan. Selain itu, dibutuhkan kepala daerah yang memang mampu dibidangnya, tanggap, kritis, memiliki kreatifitas dan inovasi yang tinggi dan kemauan yang kuat merubah daerahnya lebih baik. Untuk itu 
diperlukan pembinaan kader-kader politik dengan membekali pendidikan serta pengetahuan yang luas mengenai kearifan lokal dan pentingnya daya saing daerah. Selama ini kepala daerah sebagian besar berasal dari parpol, dengan demikian pembinaan kader politik dapat dilakukan oleh partai yang bersangkutan dan memberikan mereka tanggungjawab untuk menelurkan kader-kader politik yang berkualitas.

Suber Daya Manusia di daerah khususnya yang bekerja di pemerintaha daerah, turut menentukan mampu tidaknya suatu daerah dalam menciptakan pelayanan publik yang prima dan meningkatkan daya saing daerah. Dengan demikian, orang-orang yang duduk dalam pemerintahan daerah atau biasa disebut dengan PNS daerah, haruslah orang-orang yang memiliki kemampuan dan kapabilitas dalam melaksanakan tugasnya, tidak hanya tugas harian tetapi juga mampu menciptakan program-program baru dan inovatif di pemerintahan daerah.

Kondisi selama ini PNS di daerah diterima hanya melalui seleksi secara umum, belum ada sistem perekrutan sesuai spesialisasi kerja. Sehingga ketika mereka ditempatkan di pemerintahan, kinerja mereka hanya sebatas tugas yang dibebankan kepada mereka tanpa memberikan kontribusi serta inovasi yang lebih dalam penentuan maupun pelaksanaan program-program pemerintah. Selain itu, banyak sekali kasus KKN yang terjadi di daerah ketika perkrutan PNS. Tidak sedikit dari mereka membayar ratusan juta kepada calo agar mereka bisa diterima sebagai PNS. Jadi, kinerja mereka bukan berdasar keahlian serta motivasi untuk berkontribusi kepada daerah, dampaknya buruknya dirasakan oleh masyarakat yang tidak memperoleh pelayanan dengan baik. Kurangnya orang-orang yang berpotensi, ahli dan inovatif dalam struktur pemerintahan daerah, membuat pemerintah daerah mandek, monoton, dalam menjalankan program daerah seperti program sebelumnya. Jadi daya saing daerah pun lemah, yang terjadi, tujuan dari otonomi daerah tidak dapat terwujud.

Apabila pembukaan kesempatan CPNS di daerah diadakan bukan berdasarkan kebutuhan serta jobdesk yang ada, akan semakin menurunkan efisiensi dan efektifitas kinerja Pemerintah Daerah. Sudah bukan kabar langka lagi PNS di daerah memiliki citra yang buruk seperti datang tidak 
tepat waktu dan pulang lebih awal. Kondisi itu jelas akan berpengaruh langsung terhadap pelayanan publik yang diberikan, dampaknya masyarakat semakin sulit mendapatkan pelayanan yang dibutuhkan, padahal teorinya, pejabat pemerintah adalah pelayan masyarakat, tetapi malah mereka yang dilayani oleh masyarakat.

\section{SDM Sebagai Pilar suatu Pencapaian Pembangunan}

Karena pada dasarnya manusialah yang menjadi pelaku dan penentu. SDM seperti apa yang diperlukan, Yaitu SDM yang memiliki: moral yang baik (good morality), kemampuan kepemimpinan (leadership), kemampuan manajerial (managerial skill), dan kemampuan teknis (technical skill). Seorang kepala daerah perlu didukung oleh aparat yang mempunyai empat kualifikasi tersebut, diberbagai level jabatan dan fungsinya.

Moral yang baik menjadi prasyarat utama. Karena tanpa moral yang baik, semua kebijakan, sistem, program maupun kegiatan yang dirancang akan menjadi sia-sia. Tentunya kita menyaksikan terjadinya krisis moneter yang dimulai tahun 1997 lalu, kemudian krisis ekonomi, krisis kepemimpinan, dan masih terus berlanjut yang hingga sekarang masih dirasakan dampaknya. Sebab utama terjadinya krisis itu tidak lain adalah rendahnya moral sebagian pengambil kebijakan negeri ini.

Moral yang baik akan menghasilkan sebuah pemerintahan yang bersih dari tindakan korupsi, kolusi, dan nepotisme demi kepentingan pribadi atau golongan tertentu saja. Saat ini tuntutan penerapan 3G (Good Government Governance) terus-menerus digaungkan oleh berbagai pihak. Penerapan prinsip-prinsip transparansi \& akuntabilitas tanpa didukung oleh aparat yang bermoral baik, pada akhirnya hanya akan berhenti di tingkat wacana saja.

Oleh karena itu, sejak awal dilantik, seorang kepala daerah harus segera menyiapkan aparatnya dalam aspek moral ini. Termasuk menjadikan dirinya sebagai teladan bagi semua bawahannya. Moral yang baik belumlah cukup, tapi juga harus diimbangi dengan kompetensi. Yaitu kemampuan di bidang kepemimpinan, manajerial, dan teknis. Untuk mencapai kompetensi yang diperlukan, tidak terlepas dari sistem kepegawaian yang diterapkan. Model manajemen SDM 
berbasis kompetensi nampaknya menjadi keniscayaan. Termasuk sistem kompensasi yang memadai harus menjadi perhatian.

Selain itu perlu didukung dengan perubahan paradigma, yaitu dari mental penguasa menjadi pelayan masyarakat. Termasuk budaya kerja yang proaktif \& cepat tanggap terhadap persoalan yang dihadapi masyarakat.

\section{Masalah-masalah Peningkatan SDM dalam Upaya Pencapaian Tujuan Pembangunan Daerah}

Pengaturan Sumber Daya Manusia adalah sangat sulit dan kompleks. Manusia mempunyai pikiran, perasaan, status, keinginan, latar belakang sosial budaya dan sebagainya yang bervariasi dan sering terbawa serta ke dalam unit kerja/organiasi. Jumlah penduduk yang besar adalah merupakan salah satu modal dasar pembagunan Daerah, tetapi penduduk yang tidaak memiliki kemauan dan kemampuan untuk bekerja akan menimbulkan masalah di dalam pembangunan Daerah. Hampir setiap Negara ataupun wilayah banyak mengalami masalah di dalam menangani masalah pengangguran. Penyebab timbulnya pengangguran adalah:

a) Tidak dimilikinya pendidikan yang memadai

b) Tidak dimiliki bekal keterampilan untuk dapat melakukan aktifitas pekerjaan

$>$ Masalah-masalah yang akan timbul dari pengangguran :

a) Adanya kesenjangan sosial

b) Adanya kerawanan sosial

\section{$>$ Pendekatan Masalah}

Konsep lepas landas dalam upaya pembagunan nasional dapat diartikan sebagai sifat kemandirian yaitu kemampuan membangun dengan kekuatan sendiri. Tolak ukur pembangunan nasional tidak terpusat pada besarnya ekonomis semata tetapi sekaligus mencangkup besaranbesaran sosial budaya seperti keberhasilan dalam pembentukan nilai kelembagaan, penampungan aspirasi dan partisipasi masyarakat dalam pembangunan

Tujuan pembangunan nasional adalah mewujudkan segenap harkat dan kehendak masyarakat Indonesia dalam berbangsa dan bernegara dengan wadah Negara Kesatuan 
Republik Indonesia.Hasrat dan kehendak tersebut tercermin dalam masyarakat Indonesia yang ingin diwujudkan, yaitu masyarakat adil dan makmur baik materil maupun spiritual.

Ilmu pengetahuan dan teknologi merupakan salah satu penopang utama suatu masyarakat modern.Untuk itu maka dalam mengejar ketinggalan di bidang tersebut harus banyak belajar dan mencoba.Dalam upaya itu maka kita harus menitikberatkan kepada penguasaan kemampuan memproduksi ilmu dan teknologi tersebut, bukan sekedar memproduksikan dan mengkonsumsikan. Pendidikan keilmuan harus difokuskan kepada penguasaan metodologis pendidikan dan bukan sekedar penguasaan ilmu pengetahuan dan teoritis.

Teknologi merupakan penerapan teori-teori ilmiah dalam memecahkan masalah praktis baik berupa perangkat keras yang berupa peralatan maupun perangkat lunak yang berupa metode/teknik pemecahan masalah. Penguasaan teknologi tidak sekedar menguasai perincian teknis mengoprasikan peralatan, tetapi lebih jauh dari itu, yaitu menguasai proses berfikir yang melandasi teknologi tersebut.

Filosofi mengenai produktivitas sudah ada sejak awal peradaban manusia karena makna produktivitas adalah keinginan dan upaya manusia untuk selalu meningkatkan kualitas kehidupan dan penghidupan di segala bidang atau dapat dikatakan bahwa dalam suatu kehidupan tanpa suatu tujuan, baik individu maupun kelompok akan tidak berguna, hari ini harus lebih baik daripada kemarin dan hari esok harus lebih baik daripada hari ini.

Produktivitas memiliki 2 dimensi yaitu : efektifitas dan efisiensi. Dimensi I (efektivitas) : pencapaian unjuk kerja yang maksimal, dalam arti pencapaian target yang berkaitan dengan kualitas, kuantitas, dan waktu. Sedangkan dimensi efisiensi yang berkaitan dengan upaya membandingkan masukan dengan realiasi penggunaannya atau bagaimana pekerjaan tersebut dilaksanakan.

Produktivitas individu mendapat perhatian cukup besar hal ini didasarkan pada pemikiran bahwa sebenarnya produktivitas manapun bersumber dari individu yang melakukan kegiatan. Individu yang dimaksud adalah individu sebagai tenaga kerja yang memeiliki kualitas kerja yang 
memadai. Manfaat dari peningkatan produktivitas pada tingkat individu dapat dilihat dari :

a) Meningkatnya pendapatan jaminan sosial

b) Meningkatnya harkat dan martabat serta pengakuan terhadap potensi individu

c) Meningkatnya motivasi kerja dan keinginan berprestasi Tingginya pertumbuhan penduduk di suatu daerah tidak selalu berkaitan dengan buruknya prekonomian suatu daerah. Selama pertumbuhan penduduk diikuti dengan peningkatan penghasilan, karena semakin tinggi peningkatan Sumber Daya Manusia yang berkualitas, maka makin tinggi produktivitas yang pada akhirnya akan meningkatkan tingkat pendapatanya. daerah tersebut berarti masih dalam proses pengembangan. Namun demikian dimasa mendatang jika pertumbuhan penduduk tidak dikendalikan, maka dampaknya akan mengakibatkan turunnya daya tampung dan daya dukung lingkungan. Pertumbuhan penduduk yang tinggi berarti pula membutuhkan penyediaan pangan, perumahan lahan untuk bekerja dan lapangan kerja yang cukup.

Dengan demikian Sumber Daya Alam yang dibutuhkan makin meningkat untuk memenuhi kebutuhan manusia. Produktivitas individu dapt dinilai dari apa yag dilakukan oleh individu tersebut dalam kerjanya. Produktivitas individu adalah bagaimana seseorang melaksanakan pekerjaannya dalam mengisi pembangunan yang akan terus berlangsung.

\section{$>$ Pemecahan Masalah}

Penyelesaian yang dihadapi untuk menangani masalah pengangguran :

1. Program pembangunan yang melibatkan masyarakat pada umumnya dan khususnya masyarakat yang masih menganggur di program padat karya

2. Peningkatan mutu pendidikan dengan meningkatkan mutu pendidikan, maka tenaga-tenaga terdidik yang berkualitas akan memberikan manfaat bagi pembangunan. Daerah maupun nasional dan sekaligus dapat mengurangi pengagguran.

Pembangunan tidak merupakan suatu proses yang membujur lurus, melainkan merupakan suatu jaringan perubahan erat sekali hubungannya yang satudengan yang lain. Pendekatan terhadap pembangunan menurut pola dari atas ke bawah telah kehilangan kredibilitasnya karena 
pengalaman yang kurang mengenakkan.Partisipasi tanpa belajar dapat merupakan suatu latihan yang tidak berguna. Karena pihak-pihak yang terlibat justru kecewa dan karena tidak mendapatkan sukses yang diinginkan.

Bidang pembangunan, Negara-negara yang sedang berkembang telah mencatat sukses yang besar walaupun tidak seluruhnya sama. Setiap penilaian umum, masalah kemiskinan menghantui dunia dalam proposisi luas dan pada suatu skala yang tidak dapat diterima oleh seleuruh komponen dalam suatu bangsa dan Negara.

Pengalaman dalam bidang pembangunan selama 30 tahun menyarankan bahwa pendekatan birokratik terhadap kaum lemah harus digantidengan usaha-usaha yang menghidupkan motivsi dari dalam, akibat organisasi swadaya. Supaya swadaya itu dapat dicapai, mutlak perlua gar sebelumnya aspirsi kaum bawah dalam bidang material, sosial, dan spiritual dijabarkan dan pada waktu yang sama aspirasi itu hendaknya dikaitkan dengan ikatan-ikatan maupun kesempatan yang terkandung dalam berbagai situasi, baik ekonomi, sosial budaya dan teknologi. Dalam hal ini kita tidak membedakan tekhologi maju, madya, sederhana tetapi memilih teknologi yang kita perlukan untuk pembangunan. Walaupun demikian pemilihan ini harus didasarkan pada kriteria, yaitu : produktivitas, kesempatan membuka lapangan pekerjaan dan tidak merusak lingkungan.

Secara keseluruhan teknologi harus merupakan pelengkap kemanusiaan dalam meningkatkan taraf kehidupan ke arah yang lebih baik, sebagai individu, organisasi dan yang lebih besar lagi adalah Negara dan bangsa.

\section{E. Solusi Mengatasi Masalah Sumber Daya Manusia untuk Mencapai Pembangunan yang Berkelanjutan.}

Untuk menghadapi era Globalisasi yang sarat dengan persaingan global dan pengaruhnya, Indonesia harus memperkuat pengembangan Sumber Daya Manusianya dimulai memperkuat budaya lokal yang bisa menyaring serta melawan pengaruh globalisasi, serta memperkuat budaya lokal yang menjadi ciri bangsa kita dan menampilkannya di dunia Internasional sebagai kekuatan yang yang membedakan kita dengan negara lain. 
Dalam hubungan dengan pembangunan berkelanjutan, pengembangan SDM Indonesia harus mendapat perhatian yang besar dari pemerintah dan juga seluruh stakeholder tidak terkecuali juga seluruh lapisan masyarakat Indonesia. Pemerintah harus memperkuat sistem pendidikan beserta muatan kurikulumnya yang merupakan faktor yang sangat mempengaruhi pengembangan SDM Indonesia disamping penguatan sektor kesejahteraan dan pengentasan kemiskinan.

\section{Pengembangan Sumber Daya Manusia}

Adanya Pengembangan sumber daya manusia dapat diartikan sebagai usaha mempersiapkan orang baik sebagai individu maupun sebagai anggota masyarakat dengan segala kedudukannya. Hal ini berarti bahwa usaha itu tidak terbatas pada pembinaan kemampuan fisik melainkan juga kemampuan mental sebagai pendukung suatu kebudayaan. Dengan demikian maka pengembangan sumber daya manusia itu harus dapat mempersiapkan keterampilan jasmaniah seseorang agar ia dapat memenuhi kebutuhan hidup dirinya serta tanggungannya.

Pengembangan sumberdaya manusia juga harus dapat mempersiapkan seseorang untuk memainkan peranan sosial secara mantap sesuai dengan kedudukannya di masyarakat. Oleh karena itu praktek komunikasi atau interaksi sosial yang efektif itu hanya mungkin terselenggara kalau ada pranata yang terwujud atas dasar nilai-nilai, maka pengembangan sumberdaya manusia berarti usaha aktif penanaman sikap dan keterampilan pada anggota masyarakat sesuai dengan nilai-nilai yang berlaku sebagai pedoman hidup yang mengembalikan pola tingkah laku sosial mereka.

Berdasarkan Peraturan Daerah Provinsi Sumatera Utara no. 8 Tahun 2009 tentang Rencana Pembangunan Jangka Menengah Daerah Tahun 2009 - 2013 difokuskan pada Peningkatan Kualitas Sumberdaya Manusia Sumatera Utara baik pada tingkat aparatur pemerintahan maupun anggota masyarakat. Beberapa kebijakan yang menjadi prioritas : Pelayanan Umum meliputi perencanaan pembangunan, pemerintahan umum, kepegawaian, statistik, kearsipan, komunikasi dan informatika 
1. Ketertiban dan ketentraman

2. Ekonomi meliputi perhubungan, tenaga kerja, koperasi dan UKM, penanaman modal, pemberdayaan masyarakat dan desa, pertanian, perkebunan, peternakan, kehutanan, energi dan sumber daya mineral, kelautan dan perikanan, perdagangan, perindustrian dan transmigrasi

3. Lingkungan hidup

4. Perumahan dan fasilitas umum meliputi pekerjaan umum dan perumahanrakyat

5. Kesehatan

6. Pariwisata dan budaya

7. Pendidikan

8. Perlindungan sosial meliputi kependudukan dan catatan sipil, pemberdayaan perempuan, keluarga sejahtera dan sosial.

\section{Penguatan Kapasitas SDM sebagai Esensi Pembangunan Inovasi Nasional}

Visi Indonesia 2045 yang dicanangkan oleh Presiden Joko Widodo bahwa pada 100 tahun kemerdekaan Indonesia di tahun 2045, Indonesia mencapai posisi sebagai negara maju. Oleh karena itu, maka mau tidak mau inovasi menjadi salah satu upaya untuk mewujudkannya. Namun pada kenyataannya, dalam Global innovation Index (GII) 2020 Indonesia masih berada pada posisi 85 dari 131 negara selama tiga tahun terakhir ini, hal ini membuktikan bahwa Indonesia masih kalah bersaing dengan negara lain baik di tataran regional maupun tataran global. Hal tersebut diungkapkan Kepala Lembaga Administrasi Negara (LAN), Dr. Adi Suryanto, M.Si saat menjadi narasumber pada Badan Pengkajian dan Penerapan Teknologi (BPPT) Innovation Award dengan tema "Mencari Inovator Indonesia" yang digelar secara Virtual, Sabtu (7/11).

"Penguatan kapasitas SDM aparatur menjadi bagian yang tak terpisahkan untuk membangun kultur inovasi di dalam birokrasi, oleh karena itu inovasi harus dimulai dengan pembangunan manusia yang berkarakter dibanding dengan menghasilkan inovasi sebanyak mungkin," tambah Adi.

Adi menuturkan, upaya untuk mendorong inovasi yang menyeluruh di kalangan birokrasi sudah cukup baik dibanding dengan beberapa tahun tahun lalu, ketika Kompetisi Inovasi Sektor Publik yang diselenggarakan 
Menpan RB hanya diikuti puluhan inovator saja. Namun beberapa tahun terakhir, peserta inovasi terus bertambah sampai pada ribuan inovasi sektor publik. "Hal ini membuktikan kita telah mempersiapkan SDM IPTEK dalam birokrasi yang mampu mendorong perubahan di sektor publik dengan berbagai inovasi yang telah diciptakan" tambahnya.

Adi menjelaskan, sejak tahun 2015 LAN melalui Workshop Champion of Innovation, telah menghasilkan 743 kader inovasi yang tersebar di 16 daerah tidak hanya itu saja sampai saat ini LAN terus melakukan pendampingan inovasi terhadap 84 daerah yang melibatkan 2520 OPD melalui laboratorium inovasi. Selain itu, LAN juga terus menyiapkan kader-kader inovasi di kalangan ASN dengan melakukan sejumlah reformasi dibidang pendidikan dan pelatihan aparatur yang dapat menumbuhkan kultur inovasi oleh setiap individu ASN. Hal ini terbukti sampai saat ini lebih dari 28 ribu inovasi sektor publik telah diciptakan oleh ASN melalui berbagai pelatihan aparatur, baik pelatihan dasar, pelatihan kepemimpinan pengawas (PKP), pelatihan kepemimpinan administrator (PKA), pelatihan kepemimpinan Nasional (PKN) tingkat I dan tingkat II.

"Jadi Aparatur Sipil Negara ( ASN ) kita telah mampu menciptakan inovasi asalkan diberikan kesempatan dan kepercayaan" ungkapnya. Dengan memperkuat pembangunan SDM aparatur dalam upaya menciptakan birokrasi dengan kultur inovasi yang memberikan kemanfaatan besar bagi masyarakat, kita optimis bahwa tahun 2045 mendatang Indonesia akan keluar sebagai negara maju, tutupnya 


\section{BAB 3 \\ GLOBALISASI DAN BADAI EKONOMI}

\section{A. Pengertian Globalisasi}

Menurut asal katanya, kata "globalisasi" diambil dari kata global, yang maknanya ialah universal. Achmad Suparman menyatakan Globalisasi adalah suatu proses menjadikan sesuatu (benda atau perilaku) sebagai ciri dari setiap individu di dunia ini tanpa dibatasi oleh wilayah Globalisasi belum memiliki definisi yang mapan, kecuali sekedar definisi kerja (working definition), sehingga bergantung dari sisi mana orang melihatnya. Ada yang memandangnya sebagai suatu proses sosial, atau proses sejarah, atau proses alamiah yang akan membawa seluruh bangsa dan negara di dunia makin terikat satu sama lain, mewujudkan satu tatanan kehidupan baru atau kesatuan koeksistensi dengan menyingkirkan batas-batas geografis, ekonomi dan budaya masyarakat.

Di sisi lain, ada yang melihat globalisasi sebagai sebuah proyek yang diusung oleh negara-negara adikuasa, sehingga bisa saja orang memiliki pandangan negatif atau curiga terhadapnya. Dari sudut pandang ini, globalisasi tidak lain adalah kapitalisme dalam bentuk yang paling mutakhir. Negara-negara yang kuat dan kaya praktis akan mengendalikan ekonomi dunia dan negara-negara kecil makin tidak berdaya karena tidak mampu bersaing. Sebab, globalisasi cenderung berpengaruh besar terhadap perekonomian dunia, bahkan berpengaruh terhadap bidangbidang lain seperti budaya dan agama. Theodore Levitte merupakan orang yang pertama kali menggunakan istilah Globalisasi pada tahun 1985.

\section{Ciri Globalisasi}

Berikut ini beberapa ciri yang menandakan semakin berkembangnya fenomena globalisasi di dunia.Hilir mudiknya kapal-kapal pengangkut barang antar negara menunjukkan keterkaitan antar manusia di seluruh dunia.

- Perubahan dalam Konstantin ruang dan waktu. Perkembangan barang-barang seperti telepon genggam, televisi satelit, dan internet menunjukkan bahwa 
komunikasi global terjadi demikian cepatnya, sementara melalui pergerakan massa semacam turisme memungkinkan

- kita merasakan banyak hal dari budaya yang berbeda.

- Pasar dan produksi ekonomi di negara-negara yang berbeda menjadi saling bergantung sebagai akibat dari pertumbuhan perdagangan internasional, peningkatan pengaruh perusahaan multinasional, dan dominasi organisasi semacam World Trade Organization (WTO).

- Peningkatan interaksi kultural melalui perkembangan media massa (terutama televisi, film, musik, dan transmisi berita dan olah raga internasional). saat ini, kita dapat mengonsumsi dan mengalami gagasan dan pengalaman baru mengenai hal-hal yang melintasi beraneka ragam budaya, misalnya dalam bidang fashion, literatur, dan makanan.

- Meningkatnya masalah bersama, misalnya pada bidang lingkungan hidup, krisis multinasional, inflasi regional dan lain-lain

Kennedy dan Cohen menyimpulkan bahwa transformasi ini telah membawa kita pada globalisme, sebuah kesadaran dan pemahaman baru bahwa dunia adalah satu. Giddens menegaskan bahwa kebanyakan dari kita sadar bahwa sebenarnya diri kita turut ambil bagian dalam sebuah dunia yang harus berubah tanpa terkendali yang ditandai dengan selera dan rasa ketertarikan akan hal sama, perubahan dan ketidakpastian, serta kenyataan yang mungkin terjadi. Sejalan dengan itu, Peter Drucker menyebutkan globalisasi sebagai zaman transformasi sosial.

\section{Pengaruh Globalisasi Dalam Bidang Ekonomi}

Globalisasi perekonomian merupakan suatu proses kegiatan ekonomi dan perdagangan, dimana negara-negara di seluruh dunia menjadi satu kekuatan pasar yang semakin terintegrasi dengan tanpa rintangan batas teritorial negara. Globalisasi perekonomian mengharuskan penghapusan seluruh batasan dan hambatan terhadap arus modal, barang dan jasa.Ketika globalisasi ekonomi terjadi, batas-batas suatu negara akan menjadi kabur dan keterkaitan antara ekonomi nasional dengan perekonomian internasional akan semakin erat. Globalisasi perekonomian di satu pihak akan membuka peluang pasar produk dari dalam negeri ke pasar 
internasional secara kompetitif, sebaliknya juga membuka peluang masuknya produk-produk global ke dalam pasar domestik.

Menurut Tanri Abeng, perwujudan nyata dari globalisasi ekonomi antara lain terjadi dalam bentuk-bentuk berikut:

- Globalisasi produksi, di mana perusahaan berproduksi di berbagai negara, dengan sasaran agar biaya produksi menajdi lebih rendah. Hal ini dilakukan baik karena upah buruh yangrendah, tarif bea masuk yang murah, infrastruktur yang memadai ataupun karena iklim usaha dan politik yang kondusif. Dunia dalam hal ini menjadi lokasi manufaktur global.Kehadiran tenaga kerja asing merupakan gejala terjadinya globalisasi tenaga kerja.

- Globalisasi pembiayaan. Perusahaan global mempunyai akses untuk memperoleh pinjaman atau melakukan investasi (baik dalam bentuk portofolio ataupun langsung) di semua negara di dunia. Sebagai contoh, PT Telkom dalam memperbanyak satuan sambungan telepon, atau PT Jasa Marga dalam memperluas jaringan jalan tol telah memanfaatkan sistem pembiayaan dengan pola BOT (build-operate-transfer) bersama mitrausaha dari manca negara.

- Globalisasi tenaga kerja. Perusahaan global akan mampu memanfaatkan tenaga kerja dari seluruh dunia sesuai kelasnya, seperti penggunaan staf profesional diambil dari tenaga kerja yang telah memiliki pengalaman internasional atau buruh kasar yang biasa diperoleh dari negara berkembang. Dengan globalisasi maka human movement akan semakin mudah dan bebas.

- Globalisasi jaringan informasi. Masyarakat suatu negara dengan mudah dan cepat mendapatkan informasi dari negara-negara di dunia karena kemajuan teknologi, antara lain melalui: TV,radio,media cetak dll. Dengan jaringan komunikasi yang semakin maju telah membantu meluasnya pasar ke berbagai belahan dunia untuk barang yang sama. Sebagai contoh : KFC, celana jeans levi's, atau hamburger melanda pasar dimana-mana. Akibatnya selera masyarakat dunia -baik yang berdomisili di kota ataupun di desa- menuju pada selera global. 
- Globalisasi Perdagangan. Hal ini terwujud dalam bentuk penurunan dan penyeragaman tarif serta penghapusan berbagai hambatan nontarif. Dengan demikian kegiatan perdagangan dan persaingan menjadi semakin cepat, ketat, dan fair.

Thompson mencatat bahwa kaum globalis mengklaim saat ini telah terjadi sebuah intensifikasi secara cepat dalam investasi dan perdagangan internasional. Misalnya, secara nyata perekonomian nasional telah menjadi bagian dari perekonomian global yang ditengarai dengan adanya kekuatan pasar dunia.

\section{B. Dampak Positif Globalisasi dalam Bidang Ekonomi}

\section{Produksi global dapat ditingkatkan}

Pandangan ini sesuai dengan teori 'Keuntungan Komparatif' dari David Ricardo. Melalui spesialisasi dan perdagangan faktor-faktor produksi dunia dapat digunakan dengan lebih efesien, output dunia bertambah dan masyarakat akan memperoleh keuntungan dari spesialisasi dan perdagangan dalam bentuk pendapatan yang meningkat, yang selanjutnya dapat meningkatkan pembelanjaan dan tabungan.

\section{Meningkatkan kemakmuran masyarakat dalam suatu negara}

Perdagangan yang lebih bebas memungkinkan masyarakat dari berbagai negara mengimpor lebih banyak barang dari luar negeri. Hal ini menyebabkan konsumen mempunyai pilihan barang yang lebih banyak. Selain itu, konsumen juga dapat menikmati barang yang lebih baik dengan harga yang lebih rendah.

\section{Meluaskan pasar untuk produk dalam negeri}

Perdagangan luar negeri yang lebih bebas memungkinkan setiap negara memperoleh pasar yang jauh lebih luas dari pasar dalam negeri.

\section{Dapat memperoleh lebih banyak modal dan teknologi yang lebih baik}

Modal dapat diperoleh dari investasi asing dan terutama dinikmati oleh negara-negara berkembang karena masalah kekurangan modal dan tenaga ahli serta tenaga terdidik yang berpengalaman kebanyakan dihadapi oleh negara-negara berkembang. 


\section{Menyediakan dana tambahan untuk pembangunan ekonomi}

Pembangunan sektor industri dan berbagai sektor lainnya bukan saja dikembangkan oleh perusahaan asing, tetapi terutamanya melalui investasi yang dilakukan oleh perusahaan swasta domestik. Perusahaan domestik ini seringkali memerlukan modal dari bank atau pasar saham. dana dari luar negeri terutama dari negara-negara maju yang memasuki pasar uang dan pasar modal di dalam negeri dapat membantu menyediakan modal yang dibutuhkan tersebut.

\section{Pengaruh Negatif Globalisasi dalam Ekonomi}

\section{Menghambat pertumbuhan sektor industri}

Salah satu efek dari globalisasi adalah perkembangan sistem perdagangan luar negeri yang lebih bebas. Perkembangan ini menyebabkan negara-negara berkembang tidak dapat lagi menggunakan tarif yang tingi untuk memberikan proteksi kepada industri yang baru berkembang (infant industry). Dengan demikian, perdagangan luar negeri yang lebih bebas menimbulkan hambatan kepada negara berkembang untuk memajukan sektor industri domestik yang lebih cepat. Selain itu, ketergantungan kepada industriindustri yang dimiliki perusahaan multinasional semakin meningkat.

\section{Memperburuk neraca pembayaran}

Globalisasi cenderung menaikkan barang-barang impor. Sebaliknya, apabila suatu negara tidak mampu bersaing, maka ekspor tidak berkembang. Keadaan ini dapat memperburuk kondisi neraca pembayaran. Efek buruk lain dari globaliassi terhadap neraca pembayaran adalah pembayaran neto pendapatan faktor produksi dari luar negeri cenderung mengalami defisit. Investasi asing yang bertambah banyak menyebabkan aliran pembayaran keuntungan (pendapatan) investasi ke luar negeri semakin meningkat. Tidak berkembangnya ekspor dapat berakibat buruk terhadap neraca pembayaran.

\section{Sektor keuangan semakin tidak stabil}

Salah satu efek penting dari globalisasi adalah pengaliran investasi (modal) portofolio yang semakin besar. Investasi ini terutama meliputi partisipasi dana luar negeri ke pasar saham. Ketika pasar saham sedang meningkat, dana ini 
akan mengalir masuk, neraca pembayaran bertambah bak dan nilai uang akan bertambah baik. Sebaliknya, ketika hargaharga saham di pasar saham menurun, dana dalam negeri akan mengalir ke luar negeri, neraca pembayaran cenderung menjadi bertambah buruk dan nilai mata uang domestik merosot. Ketidakstabilan di sektor keuangan ini dapat menimbulkan efek buruk kepada kestabilan kegiatan ekonomi secara keseluruhan.

\section{Memperburuk prospek pertumbuhan ekonomi jangka panjang}

Apabila hal-hal yang dinyatakan di atas berlaku dalam suatu negara, maka dlam jangka pendek pertumbuhan ekonominya menjadi tidak stabil. Dalam jangka panjang pertumbuhan yang seperti ini akan mengurangi lajunya pertumbuhan ekonomi. Pendapatan nasional dan kesempatan kerja akan semakin lambat pertumbuhannya dan masalah pengangguran tidak dapat diatasi atau malah semakin memburuk. Pada akhirnya, apabila globalisasi menimbulkan efek buruk kepada prospek pertumbuhan ekonomi jangka panjang suatu negara, distribusi pendapatan menjadi semakin tidak ada.

\section{Cara Menanggulangi Dampak Negatif Globalisasi Bagi Bangsa dan Negara dalam Bidang Ekonomi, diantaranya :}

1. Pendidikan Moral Pancasila perlu diberikan kepada generasi penerus melalui pendidikan dari TK sampai Perguruan Tinggi.

2. Pemantapan rasa nasionalisme, pendidikan kewiraan dan kebangsaan, budi pekerti, pembinaan kegiatan pramuka, perlu diberikan kepada seluruh bangsa Indonesia melalui pendidikan di sekolah.

3. Pendidikan keagamaan dan organisasi sosial keagamaan pelru dikembangkan.

4. Pendidikan dan keterampilan usaha, kewirausahaan, peningkatan kualitas produksi dan usaha perekonomian rakyat dan peningkatan SDM di bidang teknologi informasi dan komunikasi perlu dikembangkan.

5. Pelestarian budaya daerah (lokal) dan budaya nasional yang dipromosikan kepada bangsa lain dengan berpedoman pada nilai-nilai luhur bangsa dan norma- 
norma yang tidak bertentangan dengan adapt istiadat maupun agama.

\section{E. Globalisasi: Definisi, Peran, dan Ruang Lingkup}

Dalam kehidupan sehari-hari, kata globalisasi memiliki popularitas yang cukup tinggi di kalangan masyarakat. Terminologi globalisasi sering kali menjadi topik utama diskusi antara akademisi, jurnalis, politisi, pebisnis, bahkan entertainers (Scholte, 2001). Tidak dapat dipungkiri bahwa globalisasi memang merupakan bagian dari kehidupan manusia. Globalisasi telah menandai kemajuan umat manusia, dan tentu saja globalisasi adalah hal yang tidak dapat dihindari (Cuterela, 2012). Sayangnya, terminologi globalisasi acap kali disalahgunakan. Hal ini dikarenakan para pengguna kata globalisasi tidak memahami betul pengertian dari globalisasi itu sendiri.

Pada hakikatnya, globalisasi tidak memiliki sebuah definisi yang pasti. Kendati demikian, pendapat para akademisi dapat memberikan gambaran dasar mengenai apa itu globalisasi. Malcolm Waters (1995) menjelaskan bahwa globalisasi adalah suatu proses sosial yang mana peleburan batasan geografis juga mengakibatkan peleburan sosial budaya. Bagi Smith dan Baylis (2001), globalisasi dapat diartikan sebagai proses ekskalasi interkonektivitas antar komunitas, dimana sebuah peristiwa di suatu belahan dunia berdampak pada komunitas di belahan dunia lainnya. Tidak jauh dari dua pengertian sebelumnya, Martin Albrow (1990) menyatakan bahwa globalisasi merujuk pada seluruh proses ketika orang dari seluruh dunia masuk ke dalam sebuah komunitas tunggal, yakni komunitas global. Selain itu, Marginson dan Considine (2000) menjelaskan bahwa globalisasi merupakan peningkatan dampak dari world systems terhadap berbagai aspek kehidupan manusia, seperti ekonomi, militer, sosial budaya, dan sebagainya. Dari penjelasan tersebut, globalisasi secara ringkas dapat diartikan sebagai sebuah 'proses' dan bukan sebuah 'end stage', yang mana proses globalisasi ini mampu mengaburkan batas-batas geografis.

Ketiadaan definisi yang absolut membuat penggunaan kata globalisasi menjadi inkonsisten. Setidaknya, terdapat lima istilah yang dianggap identik dengan fenomena 
globalisasi, yakni internasionalisasi, liberalisasi, universalisasi, westernisasi, dan deteritorialisasi. Sebagai istilah yang melekat dengan globalisasi, pengertian internasionalisasi berfokus pada intensifikasi interaksi dan ketergantungan antar negara. Sedangkan, istilah liberalisasi lebih merujuk kepada hal yang sarat nuansa ekonomi, dimana di dalamnya terdapat pernyataan dari beberapa ahli yang mengatakan bahwa liberalisasi adalah bentuk neokolonialisme dan kapitalisme. Universalisasi sesungguhnya mengandung pengertian sebagai penyebaran berbagai macam hal, baik informasi, gaya hidup, dan sebagainya, kepada orang di seluruh penjuru dunia. Selanjutnya, westernisasi - atau yang juga dikenal sebagai Amerikanisasi - merupakan penyebaran budaya barat yang cenderung mengikis rasa nasionalisme. Kemudian, istilah deteritorialisasi sejatinya secara ringkas dapat dimaknai sebagai penyusutan jarak (Scholte, 2001). Menilik pengertian kelima istilah tersebut, inkonsistensi penggunaan istilah globalisasi menjadi hal yang wajar, sebab pada dasarnya lima hal diatas merupakan dampak dari proses globalisasi itu sendiri.

Fenomena globalisasi sering kali diumpamakan seperti "badai", karena tidak ada satu pun orang yang mampu mengelakkannya (Riyanto, 2016). Mengingat bahwa globalisasi merupakan hal yang sangat dekat dengan kehidupan umat manusia, maka kajian terhadap fenomena globalisasi menjadi hal yang sangat krusial. Oleh karena itu, globalisasi kemudian dikembangkan menjadi sebuah disiplin ilmu yang dikenal dengan sebutan Studi Globalisasi. Studi Globalisasi merupakan studi yang mengkaji fenomena globalisasi secara khusus dan mendetail. Aspek utama yang mendorong lahirnya studi globalisasi adalah kesadaran akan besarnya pengaruh globalisasi pada dinamika kehidupan manusia. Selain itu, munculnya berbagai ancaman dan tantangan dalam proses globalisasi juga menuntut manusia untuk mempelajari globalisasi secara mendalam. Sebagaimana dalam tulisan Nad'a Kovalcikova (2014), proses internasionalisasi yang menjadi bagian dari globalisasi menyebabkan peran individu sebuah nation-state seolah diperkecil dengan tuntutan untuk menyatukan negara-negara ini dalam satu bentuk global governance yang dianggap vital demi terjalinnya kerjasama internasional. Kovalcikova juga 
menyebutkan beberapa bentuk yang dapat dikategorikan sebagai ancaman, antara lain konflik militer, ketidakstabilan energi, perusakan lingkungan, kesenjangan pertumbuhan ekonomi yang timpang antara 'negara maju' dan 'negara dunia ketiga, dan sebagainya. Maka, dengan adanya studi globalisasi, manusia diharapkan dapat lebih memahami dan menekan dampak-dampak negatif yang mungkin dihasilkan oleh fenomena globalisasi.

Persebaran globalisasi yang meluas tidak hanya mempengaruhi aspek-aspek yang bersifat ekslusif, tetapi juga merambah ke berbagai aspek kehidupan manusia seperti pendidikan, kesehatan, ekonomi, sosial budaya, teknologi informasi, dan sebagainya. Fenomena globalisasi berhasil merevolusi gaya hidup serta cara berkomunikasi manusia. Secara umum, fenomena globalisasi dapat dibagi menjadi empat poin penting, yaitu (1) globalisasi ekonomi yang ditandai dengan adanya ekspor impor produksi berupa barang atau jasa antar negara, afiliasi perusahaan multinasional, bahkan pertukaran pasar saham; globalisasi militer yang berupa aliansi pertahanan dan keamanan antar negara; (3) globalisasi lingkungan yang berupa penyebaran dalam konteks biologis, seperti penyebaran pantogen dari suatu wilayah ke wilayah lain di dunia; dan (4) globalisasi sosial dan budaya, seperti penyebaran ataupun pertukaran informasi teknologi, ilmu pengetahuan serta inovasi antar masyarakat dunia. Selain itu, fenomena globalisasi telah membentuk sejumlah network yang saling menghubungkan manusia dari tiap benua untuk saling bergantung satu sama lain. Globalisasi kemudian menghasilkan multi-relationships yang dapat dikaji secara multi dimensional, sehingga ruang lingkup globalisasi bersifat dinamis dan arbiter. Luasnya pengaruh dan dampak fenomena globalisasi secara otomatis membuat Studi Globalisasi memiliki cakupan yang sangat luas pula. Tidak hanya berfokus pada dampak dan pengaruh, Studi Globalisasi juga mengkaji hal-hal yang lebih kompleks, seperti memprediksi tantangan yang akan muncul di masa mendatang (Keohane \& Nye, 2000).

Dari penjelasan diatas, dapat disimpulkan bahwa globalisasi merupakan sebuah proses yang mana dapat mengaburkan batas-batas geografis, serta merevolusi gaya 
hidup dan cara berkomunikasi manusia. Walau pun globalisasi sangat berjasa dalam dinamika kehidupan manusia, perlu diingat bahwa fenomena globalisasi tidak hanya melulu mengenai perkembangan pesat yang positif. Maka dari itu, sikap proaktif untuk memahami dan menelaah globalisasi menjadi tanggung jawab masing-masing individu. Meski globalisasi dikatakan tidak dapat dicegah atau diputarbalikkan, penulis berpendapat bahwa kita mampu menghadapi dan meminimalisir dampak negatif dan ancaman dari globalisasi, karena bagaimanapun globalisasi adalah hasil dari proses perkembangan manusia. Selain itu, lahirnya disiplin ilmu Studi Globalisasi tentu akan sangat membantu dalam menentukan strategi untuk menghadapi tantangantantangan globalisasi di masa mendatang, sehingga fenomena globalisasi senantiasa dapat membawa keuntungan bagi kehidupan umat manusia.

Menurut penulis Kondisi ekonomi mengalami berbagai tantangan baik dari segala macro ataupun dari segala mikro dan ini bukan hanya terjadi di Negara berkembang, tetapi juga terjadi di Negara maju. Suatu ekonomi yang baik, apabila tercipta sinergitas yang saling terkait dengan yang lainnya sedangkan ekonomi tidak berjalan,apabila tidak terjalin interkonektivitas kecenderungan permasalah ekonomi lebih di domininasi oleh masyarakat berkembang, dimana Negara berkembang tidak memiliki kestabilan ekonomi, social, politik, dan dalam peregerakannya cenderung dikuasai oleh orang-orang yang tidak melaksanakan fungsi perundang-undangan hal ini akan diperparah apabila penerapan hukum tidak berjalan selain itu diperparah dengan lemahnya kepemimpinan maka kondisi ini akan menciptakan badai akonomi di suatu Negara dan badai tersebut akan menimbas ke Negara lain

\section{F. Badai Ekonomi}

1. Peringatan The Fed, Badai Resesi Ekonomi AS Bisa Berlangsung Lama

Amerika Serikat (AS) dalam perjalanan panjang menuju pemulihan ekonomi yang telah resesi akibat terjangkiti pandemi COVID-19. Namun perjalanan itu sepertinya akan sangat berat dan panjang. Bank Sentral AS, The Fed memberikan peringatan bahwa pemulihan ekonomi 
AS yang terjadi saat ini sangat rentan dan berpotensi besar kembali merosot. Salah satu faktor risiko utamanya adalah meningkatnya kembali kasus positif COVID-19

Hal itu disampaikan oleh Gubernur Federal Reserve Jerome Powell dalam pertemuan tahunan National Association for Business Economics. Demikian dilansir dari CNN, Rabu (7/10/2020). "Gelombang kedua virus corona dapat secara signifikan kembali membatasi aktivitas ekonomi, belum lagi efek tragis pada kehidupan dan kesejahteraan," kata Powell. Powell menyarankan agar segera mengendalikan penyebaran virus COVID-19. Selin itu dia menegaskan kembali seruannya agar lebih banyak memberikan stimulus fiskal untuk menyelamatkan ekonomi masyarakat AS yang paling rentan.

Tetapi hanya beberapa jam setelah seruan Powell, Presiden Donald Trump menghentikan negosiasi untuk paket stimulus barunya. Hal itu diutarakan Trump di akun Twitterny. "Saya telah menginstruksikan perwakilan saya untuk berhenti bernegosiasi sampai setelah pemilihan, segera setelah saya menang, kami akan mengesahkan RUU Stimulus utama yang berfokus pada pekerja keras Amerika dan Bisnis Kecil," katanya di Twitter.

Padahal Powell sebelumnya mengatakan, pemberian stimulus fiskal akan meredam risiko yang lebih parah akibat gelombang berikutnya dari pandemi COVID-19. Meskipun pengeluaran pemerintah AS sudah setinggi langit, anggota parlemen tetap harus bertindak, kata Powell.

Federal Reserve sendiri telah memangkas suku bunga mendekati nol pada bulan Maret dan telah meluncurkan berbagai fasilitas pinjaman untuk mendukung berbagai bagian ekonomi. Sebuah survei terhadap pejabat bank sentral bulan lalu menunjukkan para pembuat kebijakan tidak berharap untuk menaikkan suku bunga lagi setidaknya hingga 2023.

Tapi laju pemulihan ekonomi telah melambat. Misalnya, setelah menambahkan lebih dari satu juta lapangan kerja baru pada Mei dan Agustus, pada September pekan lalu menunjukkan hanya 661.000 lapangan kerja baru yang bertambah.

Powell juga menekankan sekali lagi bahwa beban krisis belum merata dan bahwa perempuan, minoritas, dan 
pekerja berpenghasilan rendah berada dalam posisi yang jauh lebih buruk. Pengangguran dan kebangkrutan akan selalu menjadi bagian dari perekonomian AS.

\section{5 Badai Sekaligus Peluang Terbesar dalam Ekonomi Global}

Dunia seolah sedang "direstart", badai ekonomi sampai pandemi membuat hidup banyak orang jadi sulit. Tanpa persiapan apapun, dunia mendadak diserang Covid-19. Ada gelap, terbit juga terang. Berikut 5 tantangan dan 5 peluang ekonomi global di 2020, menurut Bank Mandiri.

\section{$>$ Tantangan}

1. Kekhawatiran gelombang susulan ke-dua dan ke-tiga Covid-19 yang menghambat pemulihan ekonomi.

2. Banyak negara berkembang menggenjot utang, demi memberi stimulus ekonomi dampak Covid-19. Tantangannya, bagaimana dengan utang jatuh tempo.

3. Belum tuntasnya perang dagang antara Amerika Serikat dengan Tiongkok, maupun antara Amerika Serikat dengan negara lain sebagai mitra dagang.

4. Volatilitas pada harga minyak mentah dunia dan komoditas. Bagi Indonesia yang jadi tantangan adalah sisi penerimaan pajak sumber daya alam.

5. Ketidakstabilan politik global / geo-politik. Misalnya konflik perbatasan India \& Tiongkok, dan politik AS yang tak lama lagi pemilu.

$>$ Peluang

1. Ekonomi digital berkembang sangat masif. Pentingnya memanfaatkan sistem digital untuk memacu ekonomi. Perubahan perilaku konsumen mendorong efisiensi ekonomi.

2. Realokasi ketergantungan pada bahan baku yang berasal dari Tiongkok. Indonesia bisa jadi hub sebagai industri manufaktur global, dengan catatan ketersediaan infrastruktur.

3. Kebijakan suku bunga rendah, akan bertahan satu tahan ke depan. Akan positif bagi dunia usaha dan emerging market seperti Indonesia.

4. Banyak sektor dunia usaha akan berkembang secara jangka menengah dan jangka panjang. Diantara dunia usaha yang makin besar pasarnya adalah kesehatan, asuransi, F\&B dan home based entertainment. 
5. Inflasi rendah mendorong pemulihan ekonomi lebih cepat. Harga barang yang rendah, mampu memacu daya beli maupun kesanggupan mengajukan utang.

"Dari tantangan dan peluang ini, Ekonomi Indonesia sebenarnya bisa positif di kuartal ke-empat 2020. Dengan catatan, mampu mencegah terjadinya gelombang susulan kasus positif Covid-19," tutur Kepala Ekonom Bank Mandiri, Andry Asmoro.

\section{Warga Indonesia Bertahan dalam Badai Ekonomi Akibat Lockdown di Melbourne}

Sudah 16 tahun Zurlia Usman, asal Malang, membuka sebuah butik di Melbourne. Dengan aturan pembatasan tahap keempat terkait pandemi COVID-19, ia terpaksa harus menutup sementara bisnisnya.

Bisnis Zurlia, yakni butik Emaan, menjadi satu dari ribuan bisnis yang terkena dampak sejak Pemerintah Victoria menutup sementara usaha yang tidak termasuk kebutuhan pokok dan mendesak, mulai Rabu malam (5/08). "Setelah turun pendapatan karena pembatasan pertama selama tiga minggu, kami sempat berharap bisa naik lagi pelan-pelan setelah dilonggarkan, ternyata di luar dugaan harus tutup sementara lagi." Zurlia mengaku jika pengeluaran terbesarnya saat ini adalah membayar uang sewa bangunan yang terletak di kawasan Coburg, sekitar 7 kilometer dari pusat kota Melbourne. "Yang memberatkan untuk bisnis kami adalah sewa gedung yang cukup tinggi," ujarnya kepada Erwin Renaldi dari ABC Indonesia.

Tapi Zurlia mengatakan ia bersyukur karena di tengah pandemi COVID-19, ia telah bernegosiasi dengan pemilik bangunan untuk mendapatkan keringanan, setelah menunjukkan adanya penurunan pendapatan. Ia juga mengaku salah satu yang membuat butik Emaan bertahan adalah tunjangan uang 'Jobkeeper' dari pemerintah, yang diberikan kepada pemilik bisnis dengan penurunan omset lebih dari 30 persen.

Banyak diantara pemilik bisnis di Melbourne merasa khawatir mereka tidak akan mampu bertahan jika bisnis mereka akan ditutup sementara selama enam minggu. Tapi dengan berbekal pengalamannya menjalani bisnis butik selama belasan tahun, Zurlia yakin jika ia akan bisa melalui "badai" dengan baik. "Kami optimis badai kali ini juga bisa 
dilalui, jadi berpikiran positif, karena bukan sesuatu yang permanen," ujar Zurlia yang kini hanya melayani pembelian online. Zurlia yang pindah ke Australia di tahun 1988 untuk meneruskan sekolahnya mengatakan banyak hal yang bisa dipelajari oleh pebisnis di Melbourne selama usaha mereka ditutup sementara, seperti melatih kemampuan beradaptasi dalam bisnis dan mencari inovasi.

\section{$>$ Berharap kembali bekerja di salon}

Kemampuan beradaptasi dengan cepat dilakukan oleh Fenny Yunita, mahasiswi Certficate III Hair Dressing dan Diploma of Beauty Therapist, yang sebelumnya memiliki pekerjaan sampingan di hotel. Sejak hotel tempatnya bekerja tutup sementara karena pandemi di bulan Maret, Fenny harus memutar otak untuk mencukupi kebutuhan sehari-harinya. Karena merasa sudah memiliki kemampuan sebagai penata rambut, ia kemudian memberanikan diri membuka jasa gunting rambut di apartemennya.

"Waktu itu belum ada larangan tidak boleh bertamu seperti sekarang, jadi yang mau gunting rambut bisa bikin janji dulu, kemudian datang ke apartemen saya," kata Fenny yang juga asal dari Indonesia. "Atau kalau ada yang memanggil [untuk potong rambut] ke rumah mereka, ... asal enggak sampai travelling sampai dua jam, saya jalani juga." 'Demi kepentingan bersama' Kisah Warga Indonesia Bertahan dalam Badai Ekonomi Akibat Lockdown di Melbourne Warga Indonesia di Melbourne menjalani kehidupan di tengah pembatasan aktivitas yang lebih ketat.

Tapi kemudian Fenny memutuskan mencari kerja di salon untuk membatasi orang yang datang ke apartemennya. Baru juga beberapa saat bekerja, ia harus berhenti sementara setelah Pemerintah Victoria memberlakukan aturan pembatasan tahap empat. "[Rabu kemarin] menjadi hari terakhir saya bekerja karena salon nggak masuk kategori bisnis yang esensial," kata dia kepada Hellena Souisa dari ABC Indonesia. "Siapa yang menyangka bakal naik ke stage 4 begini? Sekarang di rumah dulu saja sambil menunggu keadaan enam minggu ke depan, mudah-mudahan membaik dan bisa kerja lagi." Mengajar online demi uang saku

Pembatasan sosial tahap empat di Melbourne juga berpengaruh kepada Amazia Pravianti Tanuatmadja, mahasiswi Master of Education di Monash University. Amazia 
sempat bekerja di restoran Indonesia di Clayton selama satu bulan, sebelum akhirnya memutuskan untuk berhenti, ketika jumlah kasus di Melbourne semakin meningkat. "Saya khawatir dengan kasus yang meningkat dan orangtua saya di Indonesia juga khawatir. Akhirnya saya memutuskan berhenti," kata Amazia yang bekerja untuk memperoleh uang saku. Untuk memenuhi kebutuhannya, sejak April lalu, lulusan S1 Sastra Inggris Universitas Kristen Maranatha Bandung tersebut mengajar Bahasa Inggris online untuk murid-murid di Indonesia. "Saya membantu usaha teman di Indonesia yang kebetulan punya kursus Bahasa Inggris online," kata Amazia kepada Sastra Wijaya dari ABC Indonesia. "Jumlah murid tergantung kadang ada private atau ada kelas regular, yang satu kelas bisa sampai 15 orang." Ia berharap agar kondisi di Victoria, khususnya Melbourne, bisa cepat pulih sehingga dapat mencari pekerjaan baru. "Saya tetap ingin mencari pekerjaan di Melbourne kalau bisa, karena jamnya lebih enak juga. Itu juga akan membantu tidak merepotkan keluarga karena biaya pendidikan yang sudah mahal."

Tenaga konstruksi kehilangan jam kerja Warga asal Indonesia lainnya, Reygi Raymon mengaku sempat merasa sangat senang ketika mendengar jam kerjanya kembali normal, yaitu empat sampai lima hari per minggu awal Juni lalu, saat Victoria masih di pembatasan tahap ketiga.

Namun, ketika kebijakan tahap keempat mulai diberlakukan pekan lalu, Reygi yang berstatus tenaga 'casual' di bidang konstruksi, tidak lagi menerima panggilan kerja. Ini karena

Reygi yang sudah bekerja di bidang konstruksi sejak November 2019 tidak lagi memiliki penghasilan dan terpaksa mengandalkan tabungan untuk bertahan hidup. "Sebenarnya proyek berjalan seperti biasa. Tapi karena saya pekerja serabutan, jadi saya harus menunggu kabar dari supervisor kapan bisa bekerja lagi," kata Reygi yang berasal dari Bali. Kepada ABC, ia mengatakan sejak awal pandemi di Australia, jam kerjanya tidak beraturan mengikuti kebijakan yang berubah-ubah di Victoria. "Sejak Maret akhir sudah terasa bedanya. Saya berharap agar Victoria paling tidak kembali ke tahap tiga, agar ada peluang kerja lebih banyak sesuai kebijakan yang berlaku." 


\section{BAB 4 \\ MENATA SDM UNGGULAN}

Strategi pengembangan SDM perlu dilakukan di era globalisasi seperti sekarang ini. Pengembangan SDM merupakan usaha yang dilakukan untuk membentuk manusia yang berkualitas dengan memiliki keterampilan, kemampuan kerja dan loyalitas kerja kepada suatu perusahaan ataupun organisasi. Terkadang, tidak sedikit perusahaan yang menolak calon pegawai karena tidak memenuhi kualifikasi yang dimaksud. Selain itu, banyak perusahaan yang dibangun, namun SDM-nya tidak tersedia atau kurang. Dalam era globalisasi ini, persaingan akan semakin ketat. Era globalisasi seakan memberikan arus teknologi dan informasi serta mobilitas sumberdaya manusia dari satu tempat ke tempat lain. Salah satu pengembangan SDM yang harus dilakukan adalah melalui pendidikan. Pendidikan sangat penting dalam mengembangkan SDM karena pengetahuan akan diperoleh salah satunya dengan pendidikan. Orang yang tingkat pendidikannya rendah, cenderung tidak memiliki kemampuan dalam bekerja. Perusahaan pun pada dasarnya menyeleksi calon karyawan dilihat dari tingkat pendidikannya.

Di Indonesia sendiri, angka kemiskinan yang terjadi masih sangat tinggi. Salah satu faktor yang menyebabkannya adalah rendahnya tingkat pendidikan masyarakat, sehingga tidak memiliki pekerjaan dan meningkatkan angka pengangguran. Oleh karena itu, pemerintah mengupayakan adanya wajib belajar 9 tahun untuk membentuk SDM yang berkualitas di masa mendatang. Kemudian, masyarakat dengan tingkat pendidikan rendah namun memiliki keterampilan, akan dikembangkan melalui UKM atau Usaha Kecil Menengah yang sekarang ini banyak dilakukan didesadesa.

\section{A. Strategi Pengembangan SDM}

Strategi pengembangan SDM pada dasarnya tidak hanya melalui pendidikan dan pengembangan keterampilan, namun ada banyak cara untuk mengembangkannya. Strategi pengembangan SDM menurut Jons, 1928 dalam Sarwono, 1993, antara lain : 
1. Melalui pelatihan.

Pelatihan bertujuan untuk mengembangkan individu dalam bentuk peningkatan keterampilan, pengetahuan dan sikap.

2. Pendidikan.

Pengembangan SDM melalui pendidikan bertujuan untuk meningkatkan kemampuan kerja, dalam arti pengembangan bersifat formal dan berkaitan dengan karir.

3. Pembinaan.

Pembinaan bertujuan untuk mengatur dan membina manusia sebagai sub sistem organisasi melalui programprogram perencana dan penilaian, seperti man power planning, performance apparaisal, job analytic, job classification dan lain-lain.

4. Recruitment.

Recruitment ini bertujuan untuk memperoleh SDM sesuai klasifikasi kebutuhan organisasi dan sebagai salah satu alat organisasi dalam pembaharuan dan pengembangan.

5. Melaluui Perubahan sistem.

Perubahan sistem memiliki tujuan untuk menyesuaikan sistem dan prosedur organisasi sebagai jawaban untuk mengantisipasi ancaman dan peluang faktor eksternal.

Dalam pengembangan SDM tidak boleh dilakukan secara sembarangan karena hal ini menyangkut kualitas SDM untuk sebuah organisasi atau perusahaan. SDM yang berkualitas akan membantu perusahaan untuk dapat lebih berkembang dan mencapai tujuan perusahaan.

\section{B. Strategi Pengembangan SDM Pada Perusahaan}

Pengembangan SDM tidak hanya dilakukan dikalangan masyarakat saja namun juga dilakukan di perusahaan dengan mengembangkan potensi karyawannya. Strategi pengembangan SDM yang dilakukan oleh perusahaan adalah :

1. Memberi kesempatan kepada karyawan untuk menyalurkan ide dan gagasan Perusahaan yang berkembang adalah perusahaan yang mau menerima ide dan gagasan dari para karyawannya. Dalam suatu perusahaan, karyawan juga berkontribusi 
dalam mengembangkan perusahaan atau sebagai roda penggerak suatu perusahaan.

Karyawan juga butuh dihargai dengan menyediakan tempat untuk mencurahkan semua ide dan gagasan yang mereka punya. Tidak dipungkiri bahwa karyawan juga memiliki ide dan gagasan yang lebih fresh dan lebih potensial. Dengan memberikan kesempatan kepada karyawan untuk menyalurkan ide mereka, berarti membiarkan karyawan tersebut berkembang dan mengembangkan potensi yang mereka miliki.

Hilangkan sikap otoriter yang tidak ingin mendengarkan ide, gagasan ataupun saran dari karyawannya karena hal tersebut hanya akan membuat karyawan menjadi tidak berkembang dan kurang produktif serta membentuk karyawan sebagai sebuah mesin untuk bekerja.

2. Memberi penghargaan.

Memberi penghargaan kepada karyawan merupakan salah satu strategi pengembangan SDM, mengapa? Karena pemberian penghargaan merupakan satu bentuk apresiasi yang diberikan oleh perusahaan kepada karyawannya. Dengan adanya pemberian penghargaan kepada karyawan berprestasi, hal tersebut akan membuat karyawan lainnya termotivasi untuk dapat menjadi lebih baik. Hal tersebut akan memberi kontribusi besar terhadap perusahaan dalam mengembangkan perusahaannya.

3. Mengadakan pelatihan.

Pelatihan dilakukan bukan semata-mata untuk pribadi karyawannya saja, namun juga perusahaannya. Perusahaan tidak akan berkembang tanpa karyawan yang memiliki keterampilan dan minat kerja yang tinggi. Dengan adanya pelatihan, diharapkan mampu menggali potensi para karyawan dan mengembangkan keterampilan yang mereka miliki. Demikian beberapa strategi pengembangan SDM untuk membentuk SDM yang berkualitas yang memiliki keterampilan dan meningkatkan kemampuan dalam bekerja.

\section{Tantangan BUMN Menata SDM Milenial}

Perubahan model bisnis dan era digitalisasi menuntut kesiapan pelaku usaha dalam mengelola sumber daya manusia (SDM). Korporasi ditantang untuk mampu memanfaatkan talenta kaum milenial yang ke depan bakal 
semakin dominan. Jumlah generasi milenial yang berdasarakan Survei Sosial Ekonomi Nasional (Susenas) mencapai 88 juta jiwa atau 33,7\% dari total jumlah penduduk Indonesia, di satu sisi merupakan kabar baik. Namun, bagi mereka yang belum siap menampung dan beradaptasi dengan lingkungan milenial, kondisi ini jelas menjadi persoalan yang tidak mudah. Padahal, kebutuhan akan talenta milenial terbaik tidak bisa dihindari lagi oleh pelaku usaha termasuk Badan Usaha Milik Negara (BUMN). Inilah yang membuat perusahaan pelat merah harus berlomba mereformasi kebijakan maupun cara perekrutan SDM yang tepat sesuai dengan dinamika zaman. Sekretaris Kementerian BUMN Imam A Putro mengakui, diperusahaan pelat merah yang dinaungi kementeriannya, memang ada tantangan tersendiri dalam menangkap keinginan generasi millenial. Untuk itu perlu ada penyesuaian sejak awal penerimaan, pengembangan SDM hingga pensiun kelak.

Saat ini ada tren perilaku milenial yang suka berpindah-pindah kantor dan tidak ingin pensiun di kantornya yang sama. Kita coba cari solusi untuk merespons karakter pekerja milenal yang cenderung cepat bosan pada satu pekerjaan, BUMN harus bisa saling memanfaatkan dan bertukar SDM. Misalkan, pegawai Bulog bisa saja pindah ke perusahaan pertambangan atau perkebunan. Ini untuk mereduksi yang suka pindah-pindah kerja. Lalu kita bangun Dana Pensiun kebanggaan semua BUMN. Jadi tidak ada gap lagi nantinya di kantor-kantor BUMN saat ini mulai memberikan ruang bagi milenial untuk berkreasi berupa ruangan bersama. Menurutnya, ini dibutuhkan karena tantangan ke depan masih banyak.

Meski demikian, dia mengtakan bahwa di BUMN karakter SDM generasi lama masih kuat mengakar sehingga apabila ada perubahan sistem tidak semudah membalik telapak tangan. Karena itu kita mendorong seluruh BUMN untuk mengubah ke mindset baru yaitu tidak lagi menunggu perubahan tapi harus terus memunculkan kreativitas. Direktur Riset Iconomics Alex Mulya yang melakukan riset BUMN dalam pandangan milenial, menemukan data bahwa milenial memprioritaskan tempat bekerja yang bisa menampung kreasi karyawan. Temuan ini agak berbeda dengan kalangan yang berusia di atasnya atau generasi $\mathrm{z}$ di 
mana mereka lebih membutuh keamanan dan kepastian jam kerja. Karakter milenial lainnya adalah mereka suka berpindah-pindah dan tidak ingin pensiun di tempat bekerja yang sama yakni 79\%, dibandingkan generasi senior yang ingin tetap di satu perusahaan $46 \%$.

Seperti diketahui definisi generasi milenial adalah mereka yang masuk kelompok dengan tahun kelahiran antara 1980-2000. Generasi ini, terbagi dalam tiga kelompok yakni early age (usia 19-24 tahun), midle term age (25-30 tahun), dan late age (31-36 tahun). Adapun generasi z merupakan sebutan untuk mereka yang lahir antara 1965-1980. Dalam survei yang dilakukannya beberapa waktu lalu, terungkap bahwa 33\% menyatakan bahwa perusahaan BUMN belum menjadi pilihan tempat bekerja yang utama baik untuk generasi milenial maupun kelompok seniornya. Adapun terkait suasana kerja, dalam riset itu disebutkan bahwa tempat favorit bekerja bagi generasi milenial adalah rumah dan kafe (56\%). Sementara generasi senior berbeda karena lebih nyaman bekerja di kantor (72\%). Temuan lain ada lebih dari $60 \%$ milenial menganggap penting peran aktif CEO pada media sosial (medsos) dan ini berpengaruh pada citra perusahaan dan produk. Bahkan, ada 38\% milenial mencari akun medsos CEO terlebih dahulu sebelum mereka melamar kerja. Ada kecenderungan anak-anak muda yang lebih ambisius lebih menyukai bekerja di swasta. Kecenderungan ini, menuntut perusahaan-perusahaan BUMN agar ke depan bisa berubah untuk menarik kaum milenial.

\section{$>$ Harus Kreatif}

Direktur Human Capital BRI Herdy Harman mengatakan, perseroan sangat menyadari tantangan kebutuhan SDM di masa mendatang. Menurutnya, strategi paling menarik yang akan dikembangkan adalah talent pool. Model ini mendorong perseroan agar bisa menarik bagi talenta terbaik untuk melamar. Kami harus jaga talenta unggul yang sudah masuk. Mereka harus betah terutama dalam industri yang kompetitif. Tim human capital harus kreatif memberikan penawaran seperti jam kerja fleksibel, yang penting produktif. Ini harus terus diantisipasi. Tantangan bisnis ke depan sangat butuh talenta unggulan. Karyawan milenial akan membutuhkan area kolaborasi. Untuk itu, mereka harus didukung untuk bisa bekerja di mana 
saja. Ke depan Pusdiklat akan ke arah virtual supaya fleksibel. Karena para atasan akan marah karena harus fokus kejar target. Sehingga kami juga harus kreatif. Bikin knowledge system di gadget dan mereka bisa belajar di mana saja.

\section{Pengelolaan Manajemen Sumber Daya Manusia (SDM) Dalam Perusahaan}

Manajemen Sumber Daya Manusia (SDM) merupakan salah satu elemen terpenting yang akan memutar roda perusahan terus berjalan. Meskipun ini tidak berhubungan langsung dengan keuangan atau pendapatan perusahaan, namun secara tidak langsung dapat berimbas pada kinerja perusahaan. Hal ini karena pada dasarnya sumberdaya manusialah yang bergerak mengelola perusahaan. Manajemen SDM sangat perperan penting untuk mengatur pengelolaan SDM dan sumberdaya perusahaan agar memberikan hasil maksimal dan memiliki loyalitas tinggi. Selain itu juga akan memiliki profesionalitas terbaik yang dapat diandalkan untuk mencapai tujuan dan sasaran perusahaan.

Setiap jajaran SDM harus menciptakan SDM yang handal dan melakukan training, coaching dan motivation pada setiap karyawan agar mampu menjalankan tugas sebagaimana mestinya. Kemampuan inilah yang akan menjadi salah satu kunci kemajuan dan keberhasilan dari sebuah perusahaan. Bahkan daya saing tinggi akan membuat karyawan siap dengan tantangan arus globalisasi dan membuat perusahan mampu memanfaatkan peluang sebaik baiknya. Dalam jangka panjang, perusahan melalui manajemen sumberdaya manusia akan diarahkan untuk :

1. Memberikan kesempatan sumber daya manusia untuk berkembang menjadi pribadi yang berkualitas dan memiliki daya saing yang tinggi. Selain untuk kebaikan perusahaan juga untuk kebaikan perorangan itu sendiri.

2. Memperkuat produk unggulan di setiap unit kerja untuk menuju keunggulan kompetitif dengan membangun keterkaitan sistem produksi, distribusi, dan pelayanan di dalam perusahaan.

3. Meningkatkan penguasaan, pemanfaatan, dan penciptaan pengetahuan

4. Dapat membangun peralatan produksi yang maju dan canggih 
5. Melakukan reformasi manajemen administrasi secara sistematis dan terintegrasi agar tujuan perusahaan dapat tercapai dengan baik.

Sumber daya manusia yang bermutu semakin dibutuhkan setiap perusahan untuk mencapai sasaran perusahaan. Semakin baik kualitas sumber daya manusia dalam sebuah perusahaan maka daya saing perusahaan tersebut akan semakin baik. Perusahaan harus melakukan program training untuk meningkatkan kehandalan karyawan, kecerdasan dan integritasnya untuk perusahaan.

Training menjadi salah satu program penting yang harus dilakuka oleh setiap karyawan yang baru pertama kali masuk ke dalam perusahaan. Program ini memegang peranan penting sebagai faktor pendukung yang memegang peranan penting pada berbagai sektor. Usaha ini juga akan menyiapkan karyawan untuk dapat praktik langsung di lapangan, uji coba terobosan dan kerja sama dalam sebuah tim.

Manajemen Sumber Daya Manusia sangat penting dalam sebuah perusahaan, hal ini terlihat karena sangat dibutuhkan oleh perusahaan untuk kemajuan perusahaan tersebut. Bahkan sumber daya manusia menjadi salah satu penentu kefektifan organisasi bisnis. Keberhasilan bisnis menjadi salah satu tujuan dari pengelolaan manajemen sumber daya manusia.

Perusahaan wajib memberikan komitmen terhadap karyawannya untuk mendapatkan kesempatan mewujudkan tujuan pribadi. Komitmen ini yang tertulis pada aturan dan prosedur dan pemilihan manjer yang baik, memperjelas visi dan misi perusahaan. Selain itu juga untuk membentuk tradisi perusahaan. Perusahaan juga wajib mendorong karyawannya untuk terus melakukan pengembangan dan mengembangkan diri sebagaimana hak seorang karyawan.

Pemanfaatan sumber daya manusia haruslah berlangsung dengan baik dengan perencanaan sumberdaya yangbaik pula. Dimulai dari pengaturan kembali dan penempatan SDM pada posisi yang tepat. Menempatkan sesuai dengan kemampuan dan pengalaman yang dimilikinya. Sehingga pemberian kontribusi karyawan dapat berlangsung maksimal. 
Hal ini menjadi salah satu tuntutan penting yang harus dikuasai oleh seorang manajer SDM, apalagi dengan perkembangan zaman dan pergerakan ekonomi, arus informasi dan perkembangan iptek semakin pesat membuat kualitas SDM semakin dibutuhkan dengan kualitas terbaik.

\section{E. Pentingnya Manajemen Sumber Daya Manusia untuk Generasi Milenial}

Generasi milenial di tempat kerja telah menantang batas-batas kerja tradisional. Sementara generasi sebelumnya jarang mempertanyakan manajemen, generasi milenial - yang memiliki ekpektasi, prioritas, dan etos kerja yang unik - telah mendorong manajemen Sumber Daya Manusia (SDM) untuk melakukan perubahan untuk beradaptasi dengan perubahan kultur kerja saat ini. Tantangan HRD dalam menghadapi para milenial adalah perpindahan kerja, karena mereka senantiasa menginginkan tugas yang menantang dan pertumbuhan. Gaji yang lebih bukan solusi, melainkan manajemen SDM yang interaktif, kultur perusahaan yang menarik, inovasi, dan peningkatan karir.

Perubahan dalam manajemen Sumber Daya Manusia ini bukan hanya masalah mengabaikan jam kerja 9-5 yang tradisional dan mengijinkan gaya berpakaian casual dalam perusahaan. Perubahan yang diperlukan adalah yang menata ulang proses HR sebagai basis pengelolaan SDM untuk mengeluarkan yang terbaik dari generasi milenial ini. Kultur perusahaan menjadi penting dalam mempertahankan orang kunci dan menjaga generasi milenial dari mencari peluang lain di luar. Mereka bekerja sangat baik dalam kultur yang beragam dan inklusif. Atasan berperan penting dalam mempertahankan karyawan. Faktor lainnya termasuk komunikasi yang terbuka dengan manajemen dan mentor. Kultur kerja yang positif mendorong kerja sama, inovasi, dan hasil-hasil.

Generasi milenial tertarik pada perusahaan yang menggunakan teknologi. Mereka tidak mau terikat pada tempat kerja tertentu dan selalu terhubung. Aplikasi HRD modern mendukung para pekerja ini dengan hanya satu tombol sentuh. Training bisa dilakukan melalui video and modul-modul e-learning. Namun ada beberapa tantangan bagi HRD dalam menangani para milenial. Biasanya di awal, 
mereka perlu diajarkan menggunakan akal sehat seperti berkomunikasi tatap muka yang baik, menjaga kontak mata, dan tepat waktu. Walaupun generasi milenial mahir menggunakan teknologi, mereka mungkin perlu dibantu untuk masuk dalam dunia kerja profesional. Sekali mereka mengerti, mereka akan melaju pesat dalam pertumbuhan dan kepemimpinan yang membawa ide-ide baru dan visi-visi inovatif.

\section{$>$ Mengelola Karyawan Milenialis}

Manajemen SDM untuk generasi milenial perlu mengakomodasi gaya kerja mereka yang lebih suka di mana saja daripada di kantor setiap saat. Mereka lebih senang melihat atasan sebagai mentor dan pelatih daripada bos. Kolaborasi dan mengikutkan mereka dalam proses akan membuat para milenial merasa diterima, memberikan hasil kerja yang berkualitas, dan mempertahankan mereka. Berikut ini beberapa tips dalam mengelola generasi milenial dalam perusahaan:

- Struktur yang baik, laporan dengan tenggat waktu, gol dinyatakan dengan jelas dan progres dievaluasi. Berikan batasan-batasan.

- Berikan panduan dan kepemimpinan yang baik. Lakukan coaching dengan komitmen. Mereka ingin cepat berhasil dengan bantuan Anda.

- Yakinkan mereka kalau mereka bisa, seperti yang orang tua mereka ajarkan. Jangan menghambat mereka. Dorong mereka untuk mengeluarkan pendapat.

- Dorong mereka dengan suasana kerja sama tim yang baik. Mereka selalu ingin berkumpul bersama.

- Dengarkan mereka. Karyawan milenial mempunyai ide dan pemikiran yang ingin didengarkan.

- Berikan mereka tantangan dan perubahan. Aktivitas yang membosankan buruk bagi mereka. Mereka suka mencari sesuatu yang baru dalam pekerjaan. Apa yang akan terjadi selanjutnya selalu menarik perhatian mereka. Apresiasi mereka.

- Manfaatkan gadget mereka. Generasi milenial bahkan mau membayar biaya sendiri untuk tetap terhubung dengan dunia sekitar mereka.

- Ciptakan tempat kerja yang seimbang dengan kehidupan pribadi mereka. Generasi milenial terbiasa memiliki 
aktivitas yang padat. Mereka berolahraga, keluar dengan teman, bergabung dengan yayasan sosial, dan menghabiskan waktu bersama keluarga. Mereka bekerja keras, tapi tidak mengikuti jam kerja tetap seperti generasi sebelumnya. Rumah, keluarga, menghabiskan waktu bersama anak-anak dan keluarga adalah prioritas mereka. Ingatlah hal ini, karena ini penting bagi mereka.

- Buat tempat kerja menyenangkan. Para milenial menikmati pekerjaan mereka. Mereka mau bergaul di tempat kerja. Anda perlu kuatir jika pekerja milenial Anda tidak makan siang bersama atau merancang kegiatan perusahaan bersama-sama. Bantulah karyawan lain untuk mendukung generasi milenial.

Manajemen SDM yang baik untuk generasi milenial melibatkan integritas, kepercayaan, perubahan yang terus menerus, dan pertumbuhan yang cepat. Anda harus menjadi pemimpin yang berani membuat perubahan.

\section{$\checkmark$ Berpikir milenial.}

Program unggulan Pelalawan cerdas lahirkan SDM berkualitas menuju Pelalawan emas tujuh program prioritas pembangunan ide cemerlang Bupati Pelalawan HM Harris, yakni Pelalawan Sehat, Pelalawan Cerdas, Pelalawan Terang, Program Percepatan Pembangunan Infrastruktur Desa/Kelurahan (PPIDK), Program Peningkatan Ketahanan Pangan dan Perkebunan, Pengembangan Obyek Wisata Bono dan Program Pembangunan Kawasan Teknopolitan Pelalawan, ditargetkan akan ciptakan Pelalawan yang maju dan sejahtera di semua lini. Seperti yang sudah diamanatkan dan telah diatur menurut Peraturan daerah (Perda) Kabupaten Pelalawan Nomor 13 Tahun 2012 tentang Penyelenggaraan Pendidikan kabupaten Pelalawan dan Peraturan Bupati (Perbup) Pelalawan Nomor 13 Tahun 2013 Tentang Pendidikan Gratis.

"Pelalawan Cerdas" Adalah salah satu Program unggulan dan merupakan komitmen HM. Harris baik secara Pribadi maupun sebagai Bupati Pelalawan. Dalam Berbagai kesempatan turun ke daerah-daerah yang ada di kabupaten Pelalawan, Bupati Pelalawan HM Harris tak henti-hentinya mengimbau masyarakat untuk ikut serta dalam mensukseskan program-program tersebut merupakan bentuk upaya pemerintah kabupaten pelalawan dalam 
mensejahterahkan masyarakat. Salah satu upaya membangun pelalawan, yaitu dengan tujuh program strategis. Salah satunya demi mencerdaskan anak bangsa Indonesia dan penduli didunia pendidikan bahkan bekal untuk mencapai kesuksesan, khususnya pada masyarakat kabupaten pelalawan membuat ke tujuh Program salahnya Program "Pelalawan cerdas". Dan salah satu upaya peningkatan Indeks Pendidikan Masyarakat (IPM) Program ini kata, Bupati Pelalawan HM Harris. Program Pelalawan cerdas. Pemkab juga telah menyekolahkan puluhan. Tenaga pendidik di Yogyakarta demi meningkatkan kualitas Para pendidik. Pendidikan menjadi pondasi dasar bagi suatu daerah dalam menciptakan Sumber Daya Manusia (SDM) yang berkualitas. Dalam UUD tahun 1945 menyatakan bahwa setiap warga negara Indonesia mempunyai hak untuk mendapatkan pendidikan yang layak. Pemerintah menyusun dan menyelenggarakan sistem pendidikan nasional yang diatur oleh negara.

Negara memprioritaskan anggaran pendidikan sekurang kurangnya 20\% dari APBN dan APBD untuk memenuhi kebutuhan penyelanggaraan pendidikan nasional. Dengan adanya UU Otonomi Daerah No. 22 tahun 1999 yang kemudian disempurnakan menjadi UU No 32 tahun 2004 telah terjadi perubahan sistem pemerintahan yang sentrallistik menjadi desentralistik, dimana setiap daerah memiliki kewenangan untuk mengatur dan mengurus sistem pemerintahannya sendiri guna mensejahterakan masyarakat di daerahnya. Pelimpahan wewenang kepada daerah membawa konsekuensi terhadap pembiayaan guna mendukung proses desentralisasi sebagaimana termuat dalam pasal 12 ayat 1 UU No 32 tahun 2004 bahwa urusan pemerintahan yang diserahkan daerah disertai dengan sumber pendanaan, pengalihan sarana dan prasarana, serta kepegawaian sesuai dengan urusan yang disentralisasikan.

Sejalan dengan arah kebijakan otonomi dan desentralisasi yang ditempuh oleh pemerintah, tanggung jawab pemeritah daerah akan meningkat dan semakin luas, termasuk dalam menejemen pendidikan. Pemerintah daerah diharapkan senantiasa meningkatkan kemampuannya dalam berbagai tahap pembangunan pendidikan. 
Pemberian dan berlakunya otonomi pendidikan di daerah memiliki nilai strategis bagi daerah untuk berkompetisi dalam upaya membangun dan memajukan daerah-daerah diseluruh Indonesia, terutama yang berkaitan langsung dengan SDM dan SDA masing-masing daerah dalam upaya menggali dan mengoptimalkan potensi-potensi masyarakat yang selama ini masih terpendam. Begitu juga adanya desentralisasi pendidikan, pemerintah daerah baik tingkat I maupun tingkat II dapat memulai peranannya sebagai basis pengelolaannya sebagai pendidikan dasar. Oleh sebab itu, di era otonomi ini, sudah saatnya kita berpikir kritis untuk membangun sebuah masyarakat yang berpendidikan, humanis, demokratis dan berperadaban. Agar masyarakat selama ini dimarjinalkan dalam lubang berpikir yang ortodoks tidak lagi ada dalam bangunan dan tatanan masyarakat dinamis dan progesif.

Maka bila hal ini bisa terwujud, masyarakat juga akan merasa bangga dengan dirinya sendiri dan pada nantinya akan respek terhadap kemajuan dan pekembangan yang terjadi dalam lingkungan sosial maupun pendidikan. Karena masyarakat telah diberikan penghargaan yang tinggi sebagai mahluk sosial dan sebagai hamba Tuhan. Sehingga pendidikan masyarakat yang mencakup seluruh komponen masyarakat dan sekolah itu dapat berjalan dengan sinergis, beriringan dan selaras sesuai dengan tujuan pendidikan itu sendiri. Salah satu, bentuk perhatian pemerintah dalam menunjukan keseriusan di bidang pendidikan yakni dengan program pendidikan gratis. Hal ini pula yang dilakukan oleh Pemerintah Daerah Kabupaten Pelalawan. Dibawah kepemimpinan Bupati Pelalawan HM. Harris telah menelurkan program pendidikan gratis dalam rangka menuju pelalawan cerdas.

Pendidikan merupakan salah satu bentuk pelayanan dasar bagi masyarakat yang sekaligus sebagai parameter bagi tercapainya tingkat kesejahteraan masyarakat yang berkualitas. Upaya pemenuhan pelayanan dasar ini pun sudah dilakukan mulai dari tingkat pusat sampai daerah dengan menempatkannya sebagai prioritas pembangunan. Pada lima tahun pertama pelayanan pendidikan lebih diarahkan pada peningkatan sarana dan prasarana pendidikan seperti ruang belajar, ruang perpustakaan, ruang laboratorium, ruang UKS, 
fasilitas sanitasi dan pembangunan sekolah baru. Upaya ini merupakan dasar bagi terciptanya pelayanan pendidikan yang berkualitas, yang ditandai tidak saja tersedianya sarana dan prasarana pendidikan namunjuga peningkatan kualitas tenaga pendidik dan anak didik. Dengan melihat pada data dan informasi terkait dengan sektor pendidikan maka upaya untuk menata pelayanan pendidikan ke depan masih harus dilaksanakan secara komprehensif.

Sejalan dengan isu-isu strategis diatas, isu-isu strategis merupakan bagian penting dan sangat menentukan dalam proses penyusunan rencana pembangunan daerah khususnya disektor pendidikan. Analisis isu-isu strategis ini serta pengembangan manajemen pendidikan berbasis prestasi dan juga program kebijkan pendidikan tanpa pungutan.

Jadi tidak ada lagi kekhawatiran bagi masyarakat di Kabupaten Pelalawan yang tak mampu secara ekonomi untuk menyekolahkan anaknya. Bupati Pelalawan HM Harris secara langsung sudah terapkan program Pelalawan cerdas di Kabupaten Pelalawan. Program pendidikan gratis ini bertujuan agar tak ada lagi anak-anak usia sekolah yang tak dapat melanjutkan sekolah hanya dikarenakan alasan faktor ekonomi semata. Muara dari penerapan program pendidikan gratis ini adalah dalam rangka mempersiapkan Sumber Daya Manusia (SDM) yang handal dan mumpuni ke depannya. Apalagi saat ini banyak program-program pusat yang ditarik ke Pelalawan sehingga hal itu membutuhkan kemampuan SDM-SDM yang berkualitas dan bermutu. Kita tak mau anakanak tempatan di sini hanya menjadi penonton saja dengan banyaknya program program yang akan diterapkan di daerah ini. Karena itulah, untuk menjawab semua ini di masa yang akan datang, hal yang mendasar adalah membentuk SDMSDM yang berkualitas.

Dengan Program Pendidikan inilah peran pemerintah daerah wajib menjamin tersedianya dana dalam anggaran Pendapatan dan belanja daerah (APBD), untuk terselenggaranya pendidikan gratis ini. Dana penyelengaraannya murni berasal dari APBD Pelalawan. Program ini tidak main-main. Ada landasan hokum tentang pendidikan gratis ini di kabupaten Pelalawan. Bahwa kebijakan Pemerintah Kabupaten Pelalawan dalam hal 
pendidikan gratis yang diterapkan ini bertujuan agar tak ada lagi anak-anak usia sekolah yang tak bisa mengecap bangku sekolah. Karena itulah, dalam pendidikan gratis nanti takkan ada lagi pungutan-pungutan yang terjadi di sekolah-sekolah. Keseriusan Orang nomor satu di Pelalawan itu telah terbukti dengan disahkannya Perda No.13 tahun 2012 tentang Pendidikan gratis dan diterbitkannya Peraturan Bupati No.13 tahun 2013 sebagai petunjuk pelaksanaan Perda tersebut. Bupati HM Harris mengharapkan anak-anak dapat menikmati pendidikan gratis, dan melahirkan siswa yang berprestasi yang nantinya turut andil dalam pembangunan.

\section{F. Keunggulan Kompetitif SDM Unggulan}

Keunggulan kompetitif perusahaan bisa dibentuk melalui berbagai cara seperti menciptakan produk dengan desain yang unik, penggunaan teknologi, desain organisasi dan utilisasi sumber daya manusia. Pengelolaan organisasi atau perusahaan untuk membentuk keunggulan bersaing melalui cara-cara seperti itu, dimasa yang akan datang, akan menjadi tema penting bagi manajemen, disebabkan perubahan lingkungan ekonomi, politik, dan teknologi yang cepat dan efek persaingan global, yang pada akhirnya bermuara pada perubahan kebutuhan bisnis. Perubahan kebutuhan bisnis adalah perubahan terhadap kualitas produk, desain produk dan kualitas pelayanan.

Oleh sebab itu, konsep tentang keunggulan kompetitif atau keunggulan bersaing merupakan salah satu fokus perhatian yang penting dari manajemen, sebagai upaya meletakkan organisasi atau perubahan pada posisi persaingan pasar yang lebih kuat melalui kompetensi organisasi yang khas (distinctive competence) dibandingkan dengan kompetensi yang dimiliki perusahaan-perusahaan pesaing.

Dalam kaitan dengan keunggulan bersaing melalui utilisasi SDM, peran MSDM dalam konteks penciptaan keunggulan bersaing itu adalah, meningkatkan kualitas kontribusi semua orang dalam organisasi dengan membagikan sumber-sumber dukungan (fasilitas, kompensasi) kepada mereka agar perusahaan mampu merespons perubahan tuntutan pasar secara efektif. Dengan demikian MSDM melalui peran manajer SDM, manajer lini dan para profesional SDM, harus mampu mempersiapkan, 
mengelola dan mempertahankan SDM yang memiliki kemampuan dan komitmen yang tinggi agar mereka mampu memberikan kontribusi secara optimal terhadap pencapaian tujuan organisasi.

Kemampuan bersaing organisasi melalui SDM berarti meletakkan peran orang dalam perusahaan untuk selalu melakukan peningkatan kualitas dan inovasi baik terhadap proses, sistem maupun produk yang melalui cara ini, perusahaan diharapkan mampu mempertahankan, meningkatkan market share atau memperluas pasar dibandingkan dengan kekuatan pesaing dalam industri. Dengan argumen seperti itu, bab ini akan membahas bagaimana keunggulan kompetitif itu dibangun melalui utilisasi SDM secara efektif. Alasan yang dapat dikemukakan adalah, semua faktor keunggulan untuk bersaing seperti desain produk, teknologi dan organisasi pada akhirnya bertumpu pada dukungan SDM. Ini artinya, keberhasilan perusahaan tidak hanya dicapai melalui faktor-faktor keunggulan yang bersifat economic values seperti kekuatan aktiva tetap dan modal kerja saja, tetapi juga ditemukan oleh keunggulan kompetitif karyawan sebagai human capital.

Dalam definisi itu tersirat pengertian kunci bahwa faktor manusia dalam implementasi strategi untuk menggali peluang-peluang yang profitable dengan menciptakan keunggulan kompetitif organisasi sangat menentukan. Organisasi memerlukan tenaga-tenaga manajerial dan tenaga operasi yang capable yang memiliki visi dan kemampuan inovatif yang tinggi, yaitu menciptakan nilai dan produk yang berdaya saing tinggi. Dalam hal ini, SDM dipandang sebagai kunci menuju keberhasilan. Implikasi dari pandangan ini, manajemen harus melakukan pencarian orang-orang yang mampu, melakukan pelatihan dan pengembangan terhadap kemampuan itu, dan menciptakan lingkungan kerja atau budaya perusahaan yang supportive sebagai cara meningkatkan motivasi kerja.

\section{$\checkmark$ PERAN MSDM}

Peran MSDM dalam membangun kemampuan organisasi dan mempertahankan keunggulan kompetitif melalui faktor manusia dalam organisasi, terwujud dalam tiga cara berikut :

- Melalui proses implementasi strategi. 
- Menjadi bagian dari kesatuan strategik.

- Berperan dalam menghadapi perubahan.

\section{$\checkmark$ MELALUI IMPLEMENTASI STRATEGI}

Strategi bisnis seringkali mengalami kegagalan dalam implementasinya disebabkan ketidakmampuan para tim manajemen pelaksana menerjemahkan strategi bisnisnya ke dalam perilaku praktek. Kegagalan itu seringkali juga disebabkan oleh ketidaksamaan interpretasi tentang visi dan misi organisasi. Karena itu, sangatlah penting bagi manajemen menginformasikan dan membahas secara intensif tentang visi, dan misi strategik organisasi kepada semua level pengambil keputusan dan karyawan sehingga diperoleh pengertian yang sama tentang hal itu. Strategi SDM berperan melakukan praktek-praktek MSDM dalam membentuk kemampuankemampuan dan keahlian yang diperlukan untuk mendukung implementasi strategi bisnis yan dijalankan.

\section{$\checkmark$ MENJADI BAGIAN DARI KESATUAN STRATEGIK}

Setiap orang dalam organisasi memiliki fungsi-fungsi yang saling terkait dalam proses mencapai tujuan strategik organisasi. Karena itu, manajemen dapat membangun kemampuan organisasi dan mempertahankan keunggulan kompetitif dengan membangun kesatuan strategik organisasi. Kesatuan strategik ini ada bila semua karyawan pada berbagai level dan departemen memiliki kontribusi dan komitmen yang sama terhadap pencapaian tujuan perusahaan.

\section{$\checkmark$ BERPERAN MENGHADAPI PERUBAHAN}

Organisasi selalu menghadapi perubahan lingkungan yang seringkali tidak dapat diduga. Oleh sebab itu, organisasi harus mampu mengadopsi perubahan itu. SDM dalam organisasi harus terlibat dalam pengelolaan perubahan itu dan kapasitas untuk mengelola perubahan itu bisa ditingkatkan dengan cara menjalankan praktek-praktek MSDM secara tepat.

\section{$\checkmark$ SUMBER DAYA MANUSIA}

Hampir semua pakar SDM mengandalkan optimalisasi penggunaan SDM sebagai kunci keunggulan kompetitif bagi organisasi. Persoalannya adalah bagaimana membentuk kompetensi-kompetensi dan komitmen karyawan baik secara individu atau kelompok guna memenuhi kebutuhankebutuhan organisasi dan mengintegrasikan kompetensi- 
kompetensi tersebut ke dalam proses bisnis dan sistem manajemen yang dijalankan organisasi. Kualitas dan karakteristik karyawan yang diperlukan oleh organisasi pada hakikatnya tidak terlepas dari tantangan -tantangan bersaing yang akan dihadapi oleh organisasi sekarang maupun di masa yang akan datang. Kerena itu, praktek-praktek MSDM harus mampu membentuk kualitas kemampuan dan komitmen SDM yang sesuai dengan karakteristik perusahaan baik melalui pendekatan lunak maupun pendekatan keras.

$>$ Bagaimana SDM Menjadi Keunggulan Kompetitif Bagi Sebuah Organisasi?

Mengandalkan departemen sumber daya manusia Anda untuk merekrut karyawan yang terbaik, merancang program pelatihan yang tepat dan efektif dan membuat program berkelanjutan yang sukses dapat memberi perusahaan Anda keunggulan kompetitif. Sementara pesaing anda berjuang dengan melakukan pengelolaan tenaga kerja yang berpengalaman dan termotivasi, perusahaan Anda dapat lebih fokus pada produktivitas dan meningkatkan penjualan ketika departemen SDM Anda memainkan peran integral dalam pengembangan tenaga kerja.

\section{$>$ Hire para Profesional dengan Pengalaman}

SDM profesional bervariasi dalam jenis keterampilan dan pengalaman yang mereka bawa ke pekerjaan. Banyak administrator yang mahir dalam memproses program penggajian dan pelaksanaan tunjangan, namun memiliki sedikit status kepemimpinan daripada pekerjaan kantoran. Anda dapat meng-upgrade departemen SDM Anda untuk memasukkan spesialis rekrutmen yang juga memahami peran strategis perusahaan Anda dan dapat memainkan bagian integral dalam membentuk kesuksesan bisnis Anda. SDM Profesional tingkat eksekutif dapat membantu merancang deskripsi pekerjaan dan program pelatihan, memberi tahu Anda di mana menemukan kandidat terbaik, dan berpartisipasi dalam menentukan tingkat gaji yang akan menghasilkan karyawan baru yang terbaik.

\section{$>$ Berikan Posisi Kepemimpinan HR}

Departemen SDM sering diberi deskripsi pekerjaan dan disuruh mengisi posisi. Gaji sudah ditentukan sebelumnya dan staf SDM hanya memiliki sedikit atau tidak memasukkannya ke dalam proses perekrutan. Untuk 
memanfaatkan wawasan profesional HR, harus membawa manajer sumber daya manusia ke dalam proses perekrutan lebih lengkap. Biarkan HR berperan dalam menentukan pembayaran dan taktik perekrutan yang tepat, berapa banyak waktu yang dibutuhkan untuk merekrut talenta terbaik, dan bagaimana kebijakan perusahaan dapat diubah untuk merekrut yang terbaik.

\section{> Biarkan HR yang Menentukan Program Pelatihan}

Dengan departemen SDM yang berpartisipasi dalam menentukan dan menerapkan tujuan perusahaan, Anda dapat mengandalkan tim sumber daya manusia untuk mempertimbangkan profitabilitas perusahaan dengan setiap keputusan yang mereka buat. Selain menentukan pekerjaan karyawan dan kualifikasi yang dipersyaratkan, departemen SDM partisipatif yang aktif dapat memantau tingkat aktivitas karyawan, semangat kerja dan keberhasilan layanan pelanggan untuk merancang dan menerapkan program pelatihan yang sesuai dengan supervisor lini dan tim manajemen eksekutif.

\section{$>$ Menyediakan HR Tools untuk Memonitor Kinerja}

\section{Karyawan}

Bagian sumber daya manusia dapat membangun program untuk melacak karyawan yang menonjol. Ketika profesional sumber daya manusia Anda terlibat dalam merancang dan memberikan ulasan karyawan, mereka dapat membantu Anda menemukan bakat dan memberi saran tentang bagaimana Anda bisa melatih karyawan terbaik untuk promosi. Mereka dapat memberi pelatihan khusus kepada karyawan yang ditunjuk dan membantu Anda menemukan peluang untuk tumbuh, berfungsi sebagai mata dan telinga Anda untuk mencari kandidat terbaik yang akan mendorong perusahaan Anda meraih keunggulan kompetitif.

\section{G. Keunggulan Kompetitif Berkelanjutan}

Keunggulan kompetitif merupakan posisi unik yang dikembangkan perusahaan dalam menghadapi para pesaing, dan mungkin perusahaan dapat mengungguli mereka secara konsisten. Definisi ini menekankan bahwa keuanggulan hanya dapat dicapai dengan pengembangan diferensiasi yang jelas dan favourable dari para pesaing. Menurut Coyne(1986), keunggulan kompetitif mempunyai arti hanya bila "dirasakan" 
di pasar; dengan kalimat lain, diferensiasi dicerminkan dalam atribut produk/jasa yang merupakan kriteria kunci dalam pembelian. Lebih lanjut, keunggulan tersebut akan berkelanjutan, hanya bila para pesaing tidak bisa dengan mudah menirunya (Barney,1991). Esensinya, gap kapabilitas yang mendasari diferensiasi harus membedakan atau memisahkan perusahaan dari pesaing; bila tidak, keunggulan kompetitif yang berarti tidak eksis (coyne 1986). Secara ringkas, kondisi paling penting untuk mempertahankan keunggulan (sustainability) adalah bahwa para pesaing yang ada dan potensial tidak mampu atau tidak akan mengambil tindakan untuk menutup gap itu. Bila para pesaing dapat dan akan menutup gap, keunggulan kompetitif menurut definisi tidak sustainable.

Barney (1991) mengemukakan empat kondisi yang harus dipenuhi sebelum suatu sumber daya dapat disebut sebagai sumber keunggulan kompetitif berkelanjutan :

1. Merupakan sumber daya organisasional yang sangat berharga (Valuable),terutama dalam kaitannya dengan kemampuan untuk mengekploitasi kesempatan dan/atau menetralisir ancaman dari lingkungan perusahaan.

2. Relatif sulit untuk dikembangkan dan sehingga menjadi langka di lingkungan kompetitif.

3. Sangat sulit untuk ditiru atau diimitasi

4. Tidak dapat dengan mudah digantikan substitut yang secara signifikan.

Masalahnya adalah bagaimana "menterjemahkan" berbagai strategi, kebijakan dan praktek MSDM menjadi keunggulan kompetitif berkelanjutan.

\section{$>$ MSDM dan Keunggulan Kompetitif Berkelanjutan}

Semakin disadari bahwa dunia bisnis akan menjadi industri yang "digerakkan" oleh perkembangan ilmu pengetahuan dan teknologi (knowledge-and technology-based industry), tidak lagi hanya bergantung pada melimpahnya sumber daya alam (resource intensive industri) dan upah buruh yang murah. Menghadapi kondisi seperti ini, organisasi yang ingin mempertahankan kelangsungan hidupnya atau pertumbuhannya akan semakin tergantung pada cara pengelolaan SDMnya. Manajemen mulai mencanangkan kembali slogan "Orang adalah aset (asset) paling penting." Dan merumuskan strategi-strategi yang tepat agar concern ini 
menjadi sentral. Namun tantangan utama adalah mengarahkan organisasi untuk melakukan dua perubahan konseptual vital.

Pertama, Perusahaan seharusnya tidak hanya percaya bahwa orang merupakan aset paling penting,tetapi juga menterjemahkan keyakinan ini kedalam praktek-praktek dan prosedur-prosedur MSDM sehari- hari. Perusahaan perlu mempunyai filosofi "people first" dan "customer second". Kedua, Perusahaan yang saat ini menganggap biaya-biaya personalia, seperti misal pelatihan, sebagai pengeluaranpengeluaran over head, harus mulai memperlakukannya sebagai investasi. Dasar pemikiran makin pentingnya SDM, dan bagaimana mereka dikelola, sebagai keunggulan kompetitif adalah bahwa, banyak sumber sukses kompetitif tradisional seperti teknologi produk dan proses, proteksi pasar, akses ke sumber daya finansial dan economies of scale, meskipun memberikan competitive laverage,menjadi kurang powerfull (Pfeffer 1984). Sebagai ilustrasi, kita bahas dua masalah yang terkait dengan upaya penciptaan keunggulan kompetitif melalui investasi dalam teknologi proses.

Pertama, hanya sedikit teknologi yang proprietary artinya, perusahaan yang menjual robot atau sistem komputer untuk menganalisis produksi atau pelayanan akan menjual robot dan sistem komputer yang sama (bahkan mungkin lebih baik) kepada para pesaing. Kemampuan untuk mendapatkan benefits teknologi ini tergantung pada kemampuan manajemen perusahaan untuk mengimplementasikan secara lebih cepat dan lebih efektif. Ini hampir tidak bisa dihindari mensyaratkan keterampilan dan motivasi SDM lebih tinggi.

Kedua, investasi dalam teknologi proses canggih bukan merupakan substitut untuk keterampilan dan pengelolaan SDM krusial untuk mencapai sukses. Ini karena keterampilan lebih tinggi dibutuhkan untuk mengoperasikan, merawat dan memperbaiki peralatan yang lebih canggih dan Advanced.

Sejalan dengan makin kurang pentingnya sumber keunggulan kompetitif tradisional, faktor pembeda yang tetap krusial, dalam kondisi persaingan yang semakin ketat, adalah organisasi, SDM, dan bagaimana mereka dikelola. Semakin disadari bahwa sumber keunggulan kompetitif yang paling sulit dicopy dan lebih sustainable adalah melalui kegiatan- 
kegiatan dan praktik-praktik MSDM, karena sukses yang datang dari MSDM sering tidak transparan dan tidak Visible.

Sebagai contoh,sistem informasi yang Computerized sebagai suatu sumber keunggulan kompetitif akan lebih mudah dilihat dan ditiru para pesaing dibanding, misal, budaya dan praktekpraktek MSDM perusahaan. Pengembangan keunggulan kompetitif melalui praktek-praktek MSDM dapat dilakukan

dengan pemahaman Stratetic target dan strategic thrusts (Schuler \& Macmillan,1984). Empat sasaran strategik pengembangan SDM mencakup perusahaan itu sendiri, pelanggan, penyalur dan pemasok. Pencapaian sasaransasaran MSDM ini tentu saja memerlukan perubahan caracara pengelolaan SDM dan lingkungan kerja. Sedangkan dua Startegic thrusts, atau cara memenangkan persaingan,melalui praktek-praktek MSDM adalah efisiensi biaya dan diferensiasi.

Sejalan dengan pergeseran fokus ke MSDM,manajemen organisasi dituntut untuk mengubah secara fundamental cara kita memandang (Way of Thinking) SDM dan hubungan kerja. Ini berarti bahwa upaya pencapaian sukses diujudkan dengan memandang SDM sebagai suatu keunggulan strategik, bukan hanya sebagai sumber biaya

yang harus diminimumkan atau dihindari. Lebih lanjut, perusahaan perlu mengembangkan praktek-praktek yang menjamin perolehan kembali (returns) dari investasi dalam

SDMnya. Manajemen yang memahami keterkaitan antara

praktik-praktik MSDM dan keunggulan kompetitif akan mengembangkan program-program pengembangan dan pelatihan Skill, peningkatan komitmen kerja, dan penciptaan

iklim kerja yang kondusif untuk memuaskan berbagai kebutuhan karyawan. Pengembangan sistem kerja alternatif,sistem imbalan berdasarkan kinerja,sistem penilaian kinerja, dan program cafetaria-style benefits adalah

beberapa contoh aspek signifikan dalam MSDM di masa mendatang.

Selanjutnya, sebagai partisipan penting dalam pengambilan keputusan strategik, manajer SDM dituntut untuk dapat mengartikulasikan berbagai alasan mengapa organisasi harus mengalokasikan lebih banyak sumber dayanya untuk investasi dalam personalia. Tugas ini memerlukan ketajaman pemikiran dalam merumuskan perencanaan dan pengembangan SDM. Karena 
mengilustrasikan peranan vital SDM tidak cukup dengan slides dan bagan-bagan yang menunjukkan data statistik, manajer SDM harus mengembangkam cara-cara yang kreatif dan inovatif untuk menyakinkan para manajer lain.

\section{Tantangan yang dihadapi MSDM}

Manajemen organisasi menghadapi paling tidak lima hambatan atau tantangan dalam pengelolaan SDM (Pfeffer,1994,Skinner,1981). Berbagai tantangan ini menjadi Barriers terhadap upaya untuk meningkatkan kontribusi MSDM dalam pengembangan keunggulan kompetitif berkelanjutan.

Pertama, menyangkut asumsi-asumsi (premises) keliru tentang SDM yang dipegang oleh manajemen. Empat asumsi keliru yang masih "mewarnai" kebijakan dan praktik MSDM di banyak organisasi adalah :

$\checkmark$ Dengan manajer-manajer yang baik, MSDM jalan dengan sendirinya;

$\checkmark$ Sumber Daya Manusia adalah tidak begitu penting;

$\checkmark$ Pengendalian adalah segalanya

$\checkmark$ Setiap masalah mempunyai suatu solusi.

Kedua, banyak masalah MSDM kritis di tingkat korporat yang belum terpecahkan. Berbagai masalah tersebut antara lain berkaitan dengan peran MSDM dalam pengambilan keputusan strategik, dan kurangnya pengetahuan MSDM dikalangan para manajer puncak. Ini semua dipengaruhi oleh struktur, size, diversitas dan alokasi wewenang organisasional.

Ketiga, menyangkut pencapaian komitmen karyawan. Penciptaan komitmen ratusan atau ribuan individu dalam suatu perusahaan, agar mereka bersedia mengeluarkan energi untuk mencapai tujuan organisasi,adalah sangat sulit. Tujuan perusahaan biasanya bersifat jangka panjang dan bersifat umum, seperti pertumbuhan atau keuntungan. Padahal, para karyawan memfokuskan pada horison waktu jangka pendek untuk memenuhi berbagai kebutuhan mereka (misal, gaji, kondisi kerja, promosi dan perlakuan adil). Penciptaan hubungan antara rangkaian tujuan-tujuan tersebut tidak mudah.

Keempat, bersumber pada kenyataan bahwa banyak konsep atau teori dibidang MSDM yang tidak hanya berbeda, tetapi sering bertentangan (contradictory). Sebagai contoh 
ilustrasi paling tidak ada empat disiplin yang berbeda human relation, labor relation, personnel administrations, dan industrial engineering yang sering digunakan sebagai dasar kebijakan dan praktek MSDM. Masing-masing disiplin tersebut memberikan saran atau massages yang berbeda dalam upaya peningkatan kinerja SDM. Manajemen organisasi sering tidak tahu bagaimana meramu unsur-unsur tersebut menjadi suatu sistem MSDM perusahaan yang efektif.

Kelima, mungkin tantangan terpenting dalam lima sampai sepuluh tahun mendatang, adalah fleksibelitas: Fleksibelitas untuk melakukan adaptasi dan adjusments terhadap lingkungan yang berubah secara cepat dan semakin turbulen; fleksibilitas untuk mencoba berbagai konsep SDM baru; dan, fleksibilitas untuk menerima dan menimplementasikan perubahan-perubahan mendasar, yang kadang-kadang painful. Fleksibilitas untuk berubah ini harus dipunyai bukan karena kita ingin memilikinya, tetapi karena kita harus melakukannya, sebagai adaptasi terhadap berbagai perubahan lingkungan, seperti perubahan pelanggan, perubahan sumber dan komposisi personalia, perubahan teknologi, dan perubahan sosial budaya. Dilema kita adalah personalia organisasi, bahkan staf profesional SDM, sering menunjukkan penolakan terhadap perubahan (resistance to change), membuat orgnisasi tidak fleksibel ketika kita harus mengubah the way we do things.

\section{H. Strategi Pengembangan Sumber Daya Manusia.}

Untuk mengembangkan SDM, manajemen organisasi harus melakukan berbagai perubahan fundamental terhadap kebijakan-kebijakan dan praktek-praktek konvensional. Skinner (1981) menyarankan tiga perubahan (yang sangat relevan bagi organisasi-organisasi di Indonesia) :

- Manajemen perlu mengubah mindsets atau cara pandangan terhadap MSDM, membuang premises yang keliru di benak mereka:

- Manajemen dapat mulai untuk meningkatkan kinerja SDM dengan melakukan kegiatan-kegiatan MSDM dasar secara lebih baik (doing the basics better)

- Manajemen perlu menetapkan horison waktu tujuh tahun untuk perencanaan dan operasi SDM; 
Dengan mempunyai horison jangka waktu jangka panjang, manajemen mengembangkan filosofi, menetapkan sasaran dan merumuskan strategi untuk mencapai sasaran

tersebut dan, Manajemen perlu membuat suatu program jangka panjang untuk mengembangkan manajer-manajer umum dengan berbagai keterampilan dan pengalaman MSDM. Akhirnya, bila kita benar-benar percaya bahwa lingkungan bisnis selalu berubah secara dramatis, dan bahwa kekuatan-kekuatan yang mendasari perubahan-perubahan tersebut sebagian besar diluar kendali kita, sudah waktunya

bagi manajemen untuk mengubah sikap lama yang kaku. Manajemen perlu fleksibel untuk menerima gagasan-gagasan baru, meskipun mungkin saat ini kurang pas. "If anyone needs me, Joyce. I'll be up on the roof for about 20 minutes".

\section{$>$ Pemberdayaan Karyawan untuk Memuaskan Pelanggan}

Secara umum, manajemen sedang mengalami revolusi. Manajer dimasa depan kemungkinan akan bekerja dalam tim dan akan menerima peran yang sama sekali berbeda dalam perusahaan. Selanjutnya mereka akan melakukan lebih banyak ekspansi keluar negeri. Manajemen akan menuntut orang dengan jenis baru. Manajer memberikan arahan kepada organisasi mereka, memberikan kepemimpinan, dan memutuskan bagaimana menggunakan sumber-sumber daya organisasi untuk mencapai tujuan. Selain tugas-tugas itu, manajer harus berurusan dengan pemecahan konflik, menciptakan kepercayaan dalam atmosfer dimana kepercayaan telah teguncang dengan hebat, dan membantu menciptakan keseimbangan antara kehidupan kerja dan kehidupan keluarga. Manajer melihat pada gambaran besarnya. Dan keputusan mereka membuat perbedaan besar dalam organisasi.

Manajemen adalah proses yang digunakan untuk mencapai tujuan organisasional melalui perencanaan, pengorganisasian, kepemimpinan, dan pengendalian orangorang dan sumber-sumber daya organisasional lainnya. Perencanaan meliputi antisipasi terhadap trend dan penentuan strategi dan taktik terbaik untuk mencapai tujuan dan sasaran organisasional. Salah satu dari sasaran itu adalah untuk menyenangkan pelanggan. Tren saat ini adalah untuk membuat tim perencanaan membantu memantau lingkungan, menemukan kesempatan bisnis, dan mengawasi tantangan. 
Perencanaan adalah fungsi manajemen kunci karena fungsi yang lain sangat bergantung pada adanya rencana yang baik. Pengorganisasian adalah perancangan struktur organisasi dan penciptaan kondisi dan sistem dimana setiap orang dan setiap hal bekerja bersama untuk mencapai tujuan dan sasaran organisasi. Banyak organisasi masa kini dirancang untuk menyesuaikan pelanggan. Gagasannya adalah untuk merancang perusahaan tersebut sehingga setiap orang bekerja untuk memuaskan pelanggan dan menghasilkan laba.

Jadi, organisasi harus tetap fleksibel dan mampu beradaptasi karena kebutuhan pelanggan terus berubah. Dan organisasi harus berubah bersama mereka atau beresiko kehilangan bisnis mereka. Kepemimpinan, berarti menciptakan visi untuk organisasi dan mengomunikasikan, membimbing, melatih, dan memotivasi orang lain untuk bekerja secara efektif untuk mencapai tujuan dan sasaran organisasi. Tren yang ada adalah untuk memberdayakan karyawan, memberi mereka sebanyak mungkin kebebasan untuk memerintah dan memotivasi diri sendiri. Fungsi ini dulu dikenal sebagai pengarahan yaitu memberi tahu karyawan persisnya apa yang harus dilakukan. Dalam banyak perusahaan yang lebih kecil, itu masih merupakan peran manajer. Akan tetapi, dalam sebagian besar perusahaan besar modern, manajer tidak lagi memberi tahu orang secara persis apa yang harus dilakukan karena pekerja berpengetahuan dan yang lainnya acap kali mengetahui cara melakukan pekerjaan mereka lebih baik dibandingkan manajernya. Meskipun demikian, kepemimpinan tetap dibutuhkan untuk menjaga agar karyawan terfokus kepada tugas yang tepat pada saat yang tepat bersama dengan pelatihan, pemberian motivasi dan tugas-tugas kepemimpinan lainnya.

Pengendalian/controlling adalah penetapan standar yang jelas untuk menentukan apakah sebuah organisasi mengalami kemajuan terhadap tujuan dan sasarannya. Memberi ganjaran kepada orang-orang untuk melakukan pekerjaan yang baik dan mengambil tindakan korektif jika tidak. Pengendalian berarti mengukur apakah apa yang sebenernya terjadi memenuhi tujuan organisasi. Banyak pekerja dimasa sekarang disebut sebagai "pekerja berpengatahuan" karena mereka mempunyai pendidikan dan keterampilan untuk bersaing dengan perusahaan dimanapun. 
Sebagian besar pembelajaran itu datang dari perguruan komunitas, universitas dan semua pusat pembelajaran online. Perencanaan, fungsi manajerial yang pertama melibatkan penetapan visi, tujuan dan sasaran organisasional. Eksekutif menilai perencanaan sebagai alat yang paling berharga dimeja kerja mereka. Bagian dari proses perencanaan melibatkan penciptaan sebuah visi untuk organisasi.

Visi lebih dari sekedar tujuan. Visi merupakan penjelasan yang luas atas mengapa organisasi tersebut eksis dan kemana arah yang dituju organisasi tersebut. Sebuah visi memberikan organisasi pengertian akan tujuan dan seperangkat nilai yang secara bersama-sama, menyatukan pekerja dalam takdir bersama. Mengelola organisasi tanpa terlebih dahulu menetapkan sebuah visi dapat kontraproduktif. Hal seperti itu memotivasi setiap orang dikapal dayung untuk dengan semangat pergi ke suatu tempat. Tetapi tidak memberi tahu mereka secara tepat kemana. Sebagai hasilnya, kapal tersebut akan terus menerus berubah arah alih-alih dengan cepat menuju suatu tujuan yang telah disetujui bersama.

Karyawan bekerja bersama manajer untuk merancang sebuah pernyataan misi yang merupakan uraian mengenai tujuan mendasar dari sebuah organisasi. Sebuah pernyataan misi yang berarti harus menyinggung konsep diri organisasi, filosofi dan tujuan perusahaan, daya tahan jangka panjang, kebutuhan pelanggan, tanggung jawab sosial dan sifat dari produk atau jasa perusahaan. Pernyataan misi menjadi fondasi untuk menetapkan tujuan spesifik serta untuk menyeleksi dan memotivasi karyawan. Tujuannya adalah pencapaian luas jangka panjang yang ingin dicapai sebuah organisasi. Tujuan harus disetujui secara mutual oleh pekerja dan manajemen. Sasaran adalah pernyataan spesifik jangka pendek yang memerinci bagaimana cara mencapai tujuan organisasi. Dan sebuah proses yang berkelanjutan adalah perencanaan. Kemungkinan rencana yang berhasil kemarin tidak akan berhasil dalam pasar hari ini. Sebagian besar perencanaan mengikuti sebuah pola. Prosedur yang akan diikuti dalam merencanakan kehidupan dan karier pada dasrnya sama dengan yang digunakan bisnis untuk rencana.

Perencanaan memberikan fondasi untuk kebijakan, prosedur, dan strategi untuk mendapatkan dan menggunakan 
sumber daya untuk mencapai tujuan itu. Dalam definisi ini, kebijakan adalah panduan luas untuk tindakan, dan strategi untuk menentukan cara terbaik untuk menggunakan sumber daya. Pada tahapan strategis, perusahaan memutuskan pelanggan mana yang akan dilayani, produk atau jasa apa yang akan dijual dan area geografis dimana perusahaan akan bersaing. Oleh karena itu, beberapa perusahaan membuat rencana-rencana jangka pendek yang memungkinkan adanya respons cepat terhadap kebutuhan dan permintaan pelanggan. Tujuannya adalah untuk menjadi fleksibel dan rensponsif terhadap pasar. Proses untuk menetapkan standard dan jadwal kerja yang diperlukan untuk menerapkan sasaran taktis perusahaan. Sementara perencanaan strategis melihat pada organisasi sebagai satu keseluruhan. Perencanaan operasional berfokus pada penyelia, manajer departemen, dan karyawan individual tertentu.

Semua fungsi manajemen melibatkan sejenis pengambilan keputusan. Memilih diantara dua alternative atau lebih. Model pengambilan keputusan rasional meliputi serangkaian langkah-langkah yang acap kali diikuti manajer untuk mengambil keputusan yang logis, cerdas dan berdasar. Problem solving memecahkan masalah yang terjadi seharisehari. Pemecahan masalah lebih tidak formal dibandingkan proses pengambilan keputusan dan biasanya membutuhkan tindakan yang lebih cepat. Teknik-teknik pengambilan keputusan yang digunakan perusahaan meliputi brainstorming (memikirkan pemecahan dalam periode singkat dan tanpa penyensoran ide) dan PMI (menuliskan semua plus untuk pemecahan dalam satu kolom, semua minus dalam kolom yang lain dan implikasinya pada kolom ketiga). Manajemen puncak terdiri atas presiden dan eksekutif perusahaan penting lainnya yang mengembangkan rencna strategis. Istilah yang kemungkinan sering dilihat adalah chief executive officer/CEO, chief operating officer/COO, chief financial officer/CFO, chief information officer/CIO.

Manajemen menengah meliputi general manager, manajer divisi dan manajer cabang dan pabrik. Yang bertanggung jawab untuk perencanaan taktis dan pengendalian. Manajemen penyelia meliputi mereka yang secara langsung bertanggung jawab untuk mengawasi pekerja 
dan mengevaluasi kinerja harian mereka. Pemangku kepentingan meliputi siapa saja yang terpengaruh oleh organisasi serta kebijakan dan produknya. Itu meliputi karyawan, pelanggan, pemasok, diler, kelompok lingkungan dan masyarakat sekitar. Banyak perusahaan besar direstrukturisasi menjadi unit-unit yang lebih kecil dan lebih terfokus pada pelanggan. Merekrut karyawan yang baik telah selalu menjadi bagian penting dari keberhasilan organisasional. Perusahaan dengan pekerja yang paling inovatif dan kreatif dapat berawal dari perusahaan baru hingga menjadi pesaing utama perusahaan terkemuka hanya dalam beberapa tahun.

Setelah mereka dipekerjakan, orang-orang yang baik harus dipertahankan. Banyak orang tidak bersedia bekerja diperusahaan kecuali mereka diperlakukan dengan baik dan mendapatkan bayaran yang pantas. Karyawan dapat pergi untuk menemukan perusahaan yang menawarkan keseimbangan yang lebih baik antara kerja dan rumah. Sekarang dan dimasa depan, semua organisasi akan membutuhkan pemimpin yang dapat memasok visi serta fondasi moral dan etis untuk tumbuh. Organisasi akan membutuhkan pekerja dan manajer yang memounyai satu visi yang sama dan mengetahui cara melakukan pekerjaan secara kooperatif. Kepemimpinan yang berhasil bergantung pada tujuan dan nilai dari perusahaan, siapa yang dipimpin, dan dalam situasi apa. Gaya kepemimpinan apapun, dari otoktaris hingga free-rein dapat berhasil tergantung pada orangorangnya dan situasinya. Banyak pemimpin yang memberikan instruksi eksplisit kepada pekerja, memberi tahu mereka apa yang harus dilakukan untuk mencapai tujuan dan sasaran organisasi.

Para pemimpin progresif, berkemungkinan lebih kecil daripada pemimpin tradisional untuk memberikan instruksi spesifik kepada karyawan. Alih-alih mereka lebih berkemungkinan memberdayakan karyawan untuk mengambil keputusan oleh mereka sendiri. Dalam perusahaan yang mampu menerapkan konse tsb, peran manajer menjadi kurang seperti atasan dan direktur atau lebih, pelatih, asisten, penasihat atau anggota tim. Untuk mengukur keberhasilan dalam perusahaan yang berorientasi pada pelanggan adalah kepuasan pelanggan. Ini meliputi baik 
kepuasan dari pelanggan eksternal maupun internal. Salah satu tujuan dimasa kini adalah untuk lebih dari sekedar memuaskan pelanggan dan untuk membuat mereka senang dengan produk dan jasa yang bagusnya melampaui harapan mereka. Kriteria efektivitas organisasional lainnya dapat meliputi kontribusi perusahaan kepada masyarakat dan tanggung jawab lingkungannya di area-area sekitar bisnis tersebut. Tujuan-tujuan lainnya dapat termasuk menyenangkan karyawan, pelanggan dan pemangku kepentingan lainnya.

\section{STRATEGI MANAJEMEN SUMBERDAYA MANUSIA DAN KEUNGGULAN BERSAING}

Tahun 1990 merupakan dekade awal dimana perusahaan-perusahaan diseluruh dunia harus memulai berfikir global. Waktu dan jarak menjadi semakin tidak berarti dengan kemajuan teknologi, komunikasi, transportasi, dan arus keuangan. Produk-produk yang ditemukan dan dikembangkan disuatu negara seperti tas merk Gucci, hamburger dari Mc Donald's, pakaian pria dari Pierre Cardin, BMW dari Jerman, dan produk-produk lain mendapat tanggapan secara antusias di negara-negara lain. Tampaknya suatu pemukiman global sedang muncul. Fenomena ini mengingatkan kita tentang pemikiran Global Village yang pernah dicetuskan oleh Ohmae dan Drucker. Mereka menyatakan bahwa mekanisme perdagangan dunia saat ini digambarkan sebagai sebuah pasar disebuah desa. Artinya pasar semakin kecil (compressed) dengan dunia yang semakin terasa kecil karena dukungan kemajuan teknologi dan informasi yang tidak pernah terbayangkan sebelumnya. Teknologi dan informasi merupakan elemen penting bagi perusahaan dimasa yang akan datang sehingga memungkinkan perusahaan untuk berinovasi, beradaptasi, memberikan respon yang cepat terhadap konsumen (Chatell, 1995: 89).

Selama beberapa dekade ini banyak perusahaan telah melakukan aktifitas internasionalnya. Nestle, Toshiba, Shell, Bayer, dan masih banyak lagi perusahaan multi nasional yang sudah sangat dikenal oleh konsumen-konsumen diseluruh dunia. Perusahaan-perusahaan domestik yang sebelumnya tidak pernah berfikir akan perusahaan asing, sekarang ini menghadapi langsung pesaing-pesaing ini. Sudah tidak asing 
lagi bagi kita mendengar keberhasilan perusahaanperusahaan Jepang dibandingkan perusahaan Amerika Serikat dalam memasarkan produk-produknya berupa alat-alat elektronik, mobil, kamera, jam tangan, dan produk-produk lainnya di pasaran Amerika Serikat. Fenomena tersebut menjelaskan betapa lingkungan bisnis telah berubah secara radikal dan sangat berbeda dengan masa lalu. Perubahan ini disebabkan oleh terjadinya hipercompetition dalam perekonomian global. Menurut D'aveni dan Gunther, Hipercompetition merupakan persaingan yang terjadi dalam lingkungan yang terus menerus mengalami perubahan secara cepat dalam kurun waktu yang semakin singkat (D'aveni dan Gunther, 1995: 178) Kecepatan dan pendeknya periode perubahan lingkungan menyebabkan perusahaan tidak terlalu mudah untuk melakukan antisipasi dalam upaya menghindari kegagalan-kegagalan. Perusahaan-perusahaan yang ingin bertahan dan lebih maju dalam kondisi demikian perlu untuk mengembangkan strategi yang baru.

Dalam keadaan demikian perusahaan seharusnya memperlakukan dunia sebagai sumber penawaran dan permintaan. Mereka-mereka ini tidak terbatas pada perushaan internasional saja, tetapi juga perusahaan domestik baik besar maupun kecil. Fokus harus diarahkan pada penciptaan laba dan pertumbuhan didalam pasar global yang menunjukan arus produk, teknologi, modal, dan bisnis yang besar antar negara. Dalam kondisi perekonomian seperti ini tidak ada satupun pasar yang selamanya aman dari persaingan. Bagi perusahaan-perusahaan yang selama ini hanya beroperasi dipasar domestik lambat laun akan mengalami persaingan yang keras hingga didapatkan kenyataan bahwa pasar domestic itu tidak ada lagi, serta yang ada hanyalah pasar global. Hal tersebut diatas dimaksudkan utnuk menunjukkan bahwa bukannya semua perusahaan harus go international tetapi harus membuat perencanaan untuk pertumbuhan dan kelangsungan hidup diera persaingan global. Tentunya perusahaan tidak dapat mengandalkan untuk hidup dipasar domestik saja. Dengan kata lain tidak terdapat lagi tempat bagi perusahaanperusahaan untuk bersembunyi dari pesaing-pesaing di luar negeri. 
Dalam kondisi demikian maka tidak ada pilihan lain bagi perusahaan yang berada dalam era persaingan global untuk tidak ikut berkompetisi global melalui peningkatan kemampuan bersaing secara global. Salah satu faktor kunci dalam menentukan keberhasilan persaingan tersebut adalah melalui upaya pencapaian keunggulan kompetitif (bersaing) perusahaan atau organisasi. Alternatif pendekatan yang mungkin diterapkan oleh perusahaan atau organisasi pada kondisi seperti ini adalah melalui pengelolaan aktifitasaktifitas sumber daya manusia dalam perusahaan atau organisasi berdasarkan pada perspektif strategik. Pada prinsipnya perspektif ini menjelaskan bahwa dalam upaya mencapai keunggulan bersaing (kompetitif) maka strategi sumber daya manusia harus sesuai dengan strategi bisnis perusahaan. Tulisan ini dimaksudkan untuk menjelaskan bagaimana mengelola sumber daya manusia yang ada pada perusahaan atau organisasi guna mencapai keunggulan kompetitif pada era kompetisi global dari perspektif stategi manajemen sumber daya manusia. Kondisi perekonomian dewasa ini sudah menunjukkan kecenderungan yang bersifat global. Hubungan antar negara atau bangsa-bangsa di dunia dibidang ekonomi mulai tidak mengenal batas-batas wilayah negara secara geografis. Kenichi Ohmae (1995: 128), menyebut masa sekarang sebagai masa berakhirnya negara bangsa dan masa munculnya negara wilayah.

Negara wilayah terbentuk dari beberapa negara bangsa di suatu wilayah yang membuat kesepakatan untuk melakukan perdagangan bebas. Sebagai contoh adalah wilayah yang mencakup negara-negara Eropa Barat, ASEAN, dan Amerika Utara. Menurut Daniels dan Daniels, istilah globalisasi dapat diartikan sebagai pengkondisian yang mencakup( Daniels dan Daniels, 1993: 69):

- Pelaksanaan bisnis disejumlah negara di dunia.

- Penyeimbangan kualitas global barang dan jasa serta kebutuhan unik dari berbagai basis pelanggan local.

- Penggolongan kualitas etnosentrik yang secara cultural tidak menunjukkan batas yang jelas, apapun kebangsaannya.

- Pemanfaatan sumber dan keahlian tanpa memandang jenis kewarganegaraannya. 
Dengan mengacu pada pengertian diatas dapat dipahami bahwa dalam perekonomian global, dimanapun keberadaan konsumen di dunia ini karakteristik kebutuhan dan keinginannya cenderung tidak berbeda. Perekonomian global baru sedang terjadi yang menghadapkan perusahaanperusahaan dengan berbagai ancaman terhadap kelangsungan hidup mereka disamping peluang-peluang untuk mencapai pertumbuhan dan laba. Ohmae memandang bahwa negara bangsa telah kehilangan kemampuan untuk mengendalikan tingkat pertukaran dan proteksi mata uangnya disamping juga tidak dapat membangkitkan aktifitas ekonominya (Ohmae, 1985: 55). Oleh karena itu keterlibatan sebagai peserta dalam perekonomian global harus diperkuat hubungan aktifitas antar bangsa yang semakin dekat. Perekonomian global terbentuk oleh adanya dorongan berbagai kekuatan yang mencakup beberapa hal sebagai berikut (Dharmesta, 1997: 27) :

- Perubahan teknologi yang tercermin pada migrasi industri dari negara maju ke negara sedang berkembang.

- Realokasi dari industri-industri yang padat karya dan modal tradisional ke industri yang padat teknnologi dan keahlian

- Tingkat inflasi yang semakin tinggi, menyangkut kecepatan, ketersediaan, dan efektifitas biaya komunikasi internasional

Terciptanya perekonomian global sudah ditunjukan oleh adanya kecenderungan sejak tahun 1980-an. Ohmae, telah mengidentifikasi adanya tiga poros kekuatan ekonomi dunia, disebut Triad Power, yang mendominasi perekonomian dunia (Ohmae, 1985:19). Berbagai kaukus ekonomi multilateral yang dibentuk oleh berbagai negara dikawasan tertentu ikut berpengaruh terhadap terciptanya perekonomian global (Dharmesta, 1997:31). Tiga poros ekonomi ini meliputi Amerika Serikat, Jepang, dan masyarakat Eropa. Kombinasi produk domestic bruto dari ketiga porors tersebut membentuk dua per tiga PDB dunia, yaitu Amerika Serikat 26\%, masyarakat Eropa 25\% dan Jepang 14\%. Ekspor impor mereka menguasai empat per lima dari ekspor impor dunia. Volume perdagangan antara ketiga poros itu sebesar dua per tiga dari perdagangan dunia. Sedangkan investasi langsung asingnya (FDI) mencapai tiga per empat dari arus 
keluar FDI dunia dan dua per tiga dari arus masuk FDI dunia per tahunnya. Meskipun dominasinya terus menurun namun ketiga poros tersebut masih menjadi pusat perekonomian global di abad 21. Faktor-faktor lingkungan seperti halnya ketidakpastian, inovasi teknologi, perubahan demografis, organisasi yang menjadi lebih flat dan fleksibel, meningkatnya kolaborasi dan kompetisi multinasional berpengaruh terhadap strategi sumberdaya manusia. Hasil penelitian Fombroun (1982) menyatakan bahwa perubahan dalam pemrosesan informasi, automasi, inflasi, produksi, demografis, elitis, serta politik kepentingan kelompok berpengaruh terhadap struktur organisasi dan isu-isu sumberdaya manusia (Fombroun, 1982, 65). Fombroun menyatakan bahwa perubahan teknologi sangat berpengaruh terhadap pekerjaan-pekerjaan di bidang jasa, perubahan di bidang ekonomi sangat berpengaruh terhadap alternative kompensasi dan pelatihan karyawan serta perubahan sosial berpengaruh terhadap perubahan pengembangan organisasi, promosi dan sistem penilaian formal organisasi. Sebagai konsekuensi dari perubahan berbagai faktor-faktor lingkungan seperti halnya inovasi teknologi, perubahan demografis, serta situasi ketidakpastian lingkungan bisnis maka strategi bisnis dan sekaligus strategi sumberdaya manusianya akan mengalami perubahan. Smith, menyatakan bahwa pendekatan yang bisa digunakan dalam menyesuaikan strategi sumberdaya manusia dengan strategi bisnis atau kondisi organisasi adalah melalui penciptaan kesesuaian antara kebijakan sumberdaya manusia dengan pilihan strategi yang spesifik. Smith menyatakan bahwa meskipun rencana pemasaran, keuangan, dan teknik seringkali berubah untuk mencerminkan perubahan strategi, tetapi fungsi sumberdaya manusia seringkali diabaikan (Smith, dalam Cynthia dan Mark Lengnickhall,1990:459). Dengan demikian perlu adanya kesesuaian antara strategi bisnis dengan strategi sumberdaya manusia dikarenakan kesesuaian kedua strategi ini akan mendukung keberhasilan implementasi strategi dan pencapaian keunggulan bersaing (kompetitif) perusahaan atau organisasi. Menurut Cynthia dan Mark Lengnickhall, Typology strategi sumberdaya manusia merupakan salahsatu pendekatan yang digunakan dalam merumuskan strategi sumberdaya manusia yang sesuai dengan strategi bisnis 
(Cynthia dan Mark Lengnickhall,1990:461). Typology tersebut dinyatakan dalam bentuk matriks "Growth/Readiness". Dalam matriks tersebut, sumbu tegaknya adalah corporate growth expectations, dimana growth yang tinggi menunjukkan tingginya peluang, berbagai opsi strategi yang tersedia, cash flow yang tinggi serta ekspansi. Sumbu datarnya menyatakan organizational readiness yang menunjukkan ketersediaan atau pencapaian, skill, gaya, dan pengalaman sumberdaya manusia yang diperlukan bagi implementasi strategi. Readiness merupakan proksi bagi kelayakan implementasi dan menunjukkan seberapa baik sumberdaya manusia fit dengan kebutuhan pada situasi tersebut. Keempat kuadran pada matriks tersebut menunjukkan empat kondisi dimana strategi sumberdaya manusia akan diformulasikan agar sesuai dengan strategi bisnis perusahaan atau organisasi dalam mencapai keunggulan bersaing (kompetitif).

Keunggulan bersaing (kompetitif) merupakan satu kunci sukses bagi perusahaan atau organisasi yang berada dalam lingkungan yang terus menerus mengalami perubahan secara cepat dalam kurun waktu yang semakin singkat atau berada dalam lingkungan persaingan yang ketat. Pada prinsipnya, konsep keunggulan bersaing yang dikemukakan oleh Porter merupakan esensi dari strategi bersaing (competitive strategy). Menurut Porter, terdapat tiga strategi bersaing bagi perusahaan atau organisasi yang bertujuan menciptakan keunggulan bersaing atau competitive strategy (Porter, 1995: 149). Ketiga strategi tersebut adalah : strategi inovasi (the innovation strategy), strategi peningkatan kualitas produk/jasa (the quality enhancement strategy), dan strategi pengurangan biaya (cost reduction). Bagi perusahaan atau organisasi agar mampu berhasil dalam mengimplementasikan strategi bersaing, maka diperlukan kesesuaian antara strategi bersaingnya dengan karakteristik personel ataupun perilaku peran yang dibutuhkan. Hal ini konsisten dengan hasil penelitian yang dilakukan oleh Hay Group in Corporated dan University of Michigan and The Strategic Planing Institute yang menyatakan bahwa perusahaan yang menerapkan strategi pertumbuhan memerlukan manager puncak yang bersedia melepaskan status quo serta menyesuaikan strategi dan tujuannya pada pasar (Schuler dan Jackson, 1987:207). Peran yang diperlukan bagi sumber daya manusia (karyawan) yang 
ada pada perusahaan atau organisasi pada hakekatnya merupakan apa yang diperlukan oleh perusahaan atau organisasi terhadap sumber daya manusia (karyawan) yang dimilikinya selain faktor kemampuan teknis, pengetahuan serta kemampuan yang diperlukan dalam mengerjakan pekerjaan spesifik atau merupakan apa yang dibutuhkan dari karyawan yang bekerja bersama dengan orang lain dalam lingkungan sosial. Schuler dan Jackson menyatakan bahwa diperlukan perilaku peran tertentu bagi sumberdaya manusia (karyawan) yang ada dalam perusahaan atau organisasi agar implementasi strategi bersaing yang telah ditentukan dapat berjalan secara efektif. Perilaku peran yang dibutuhkan dalam impementasi tersebut dijabarkan sebagai berikut (Schuler dan Jackson, 1987:209):

\section{$>$ Strategi inovasi (the innovation strategy)}

Strategi inovasi merupakan strategi yang berusaha mengembangkan produk dan jasa yang berbeda dari pesaingnya. Fokus utamanya terletak pada usaha menawarkan sesuatu yang baru dan berbeda (Porter, dalam Schuler dan Jakcson, 1987:208). Menurut Schuler dan Jakcson diperlukan beberapa perilaku peran sumber daya manusia yang ada pada perusahaan atau organisasi dalam mendukung implementasi strategi inovasi tersebut. Profil perilaku peran tersebut diantaranya adalah :

1. Derajat perilaku kreatif yang tinggi,

2. Fokus jangka panjang,

3. Derajat perilaku interdependen dan kooperatif yang tinggi,

4. Perhatian yang cukup terhadap kualitas,

5. Perhatian yang cukup terhadap kuantitas,

6. Perhatian yang sama terhadap proses dan hasil,

7. Tidak takut resiko,

8. Toleransi yang tinggi terhadap ambiguity dan sesuatu yang bersifat unpredictable

$>$ Strategi peningkatan kualitas produk/jasa (the quality enhancement strategy)

Merupakan strategi yang berfokus pada upaya-upaya perbaikan atau penyempurnaan kualitas produk atau jasa yang dihasilkan. Menurut Scholer dan Jakcson terdapat delapan profil tentang perilaku peran yang diperlukan dari sumber daya manusia (karyawan) dalam mendukung 
implementasi strategi peningkatan kualitas produk jasa. Profil tersebut diantaranya adalah :

1. Perilaku yang bersifat repetitive dan predictable,

2. Fokus jangka panjang atau menengah,

3. Derajat perilaku interdependen cooperative yang moderat,

4. Perhatian yang tinggi terhadap kualitas,

5. Derajat perhatian yang moderat pada kuantitas,

6. Perhatian yang tinggi pada proses,

7. Aktifitas yang tidak berisiko,

8. Komitmen terhadap tujuan perusahaan.

Peningkatan kualitas produk/jasa seringkali merupakan perubahan sebuah proses produksi yang mensyaratkan karyawan menjadi lebih fleksible dan terlibat dalam proses produksi. Ketika pekerjaan berubah, maka berubah pulalah sistem klasifikasi pekerjaan yang ada. Hak ini terjadi pada Brunwicks Mercury Marine Division yang memangkas klasifikasi pekerjaannya dari 126 menjadi 12 sehingga menyebabkan fleksibilitas dalam proses produksi dan penggunaan karyawan. Karyawan mendapatkan kesempatan untuk mempelajari teknik-teknik ketrampilan yang baru yang pada akhirnya memiliki komitmen yang kuat pada organisasi serta bersedia untuk memberikan sesuatu yang lebih pada organisasi.

\section{$>$ Strategi Pengurangan Biaya.}

Strategi ini berusaha mendapatkan keunggulan bersaing melalui biaya produksi yang rendah. Perusahaan yang menerapkan strategi ini dicirikan oleh kontrol biaya yang ketat, minimisasi biaya overhead serta pencapaian skala ekonomis. Fokus utama diarahkan pada upaya meningkatkan produktivitas, yakni melalui biaya output per individu. Pada prinsipnya upaya pengurangan biaya ini dilakukan melalui pengurangan jumlah karyawan, penurunan tingkat upah karyawan, pemanfaatan karyawan paruh waktu, subkontrak, prosedur pengukuran dan penyederhanaan pekerjaan, perubahan aturan pekerjaan, serta fleksibilitas penugasan pekerjaan. Menurut Schuler dan Jackson, terdapat beberapa profil perilaku sumberdaya manusia (karyawan) yang diperlukan dalam mendukung implementasi strategi pengurangan biaya. Profil tersebut adalah sebagai berikut:

1. Perilaku yang repetitive dan predictable, 
2. Fokus jangka pendek,

3. Aktivitas individual atau otonomi,

4. Perhatian yang cukup terhadap kualitas,

5. Perhatian yang tinggi terhadap kuantitas,

6. Perhatian utama pada hasil,

7. Aktivitas yang beresiko rendah,

8. Drajat yang tinggi terhadap stabilitas 


\section{BAB 5 \\ KEARIFAN LOKAL}

\section{A. Pengertian Kearifan Lokal}

Menurut bahasa, keafiran lokal terdiri dari dua kata, yaitu kearifan dan lokal. Di dalam KBBI (Kamus Besar Bahasa Indonesia), kearifan artinya bijaksana, sedangkan local artinya setempat. Dengan demikian pengertian kearifan lokal menurut tinjauan bahasa merupakan gagasan-gagasan atau nilai-nilai setempat atau (lokal) yang bersifat bijaksana, penuh kearifan, bernilai baik yang tertanam dan diikuti oleh anggota masyarakatnya di tempat tersebut.

Sementara Moendardjito (dalam Ayatrohaedi, 1986:40-41) mengatakan bahwa unsur budaya daerah potensial sebagai localgeniuskarena telah teruji kemampuannya untuk bertahan sampai sekarang. Ciri-ciri kearifan lokal tersebut adalah sebagai berikut:

1. mampu bertahan terhadap budaya luar,

2. memiliki kemampuan mengakomodasi unsur-unsur budaya luar,

3. mempunyai kemampuan mengintegrasikan unsur budaya luar ke dalam budaya asli,

4. mempunyai kemampuan mengendalikan,

5. mampu memberi arah pada perkembangan budaya.

Menurut Antariksa (2009), kearifan lokal merupakan unsur bagian dari tradisi-budaya masyarakat suatu bangsa, yang muncul menjadi bagian-bagian yang ditempatkan pada tatanan fisik bangunan (arsitektur) dan kawasan (perkotaan) dalam geografi kenusantaraan sebuah bangsa. Dari penjelasan beliau dapat dilihat bahwa kearifan lokal merupakan langkah penerapan dari tradisi yang diterjemahkan dalam artefak fisik. Hal terpenting dari kearifan lokal adalah proses sebelum implementasi tradisi pada artefak fisik, yaitu nilai-nilai dari alam untuk mengajak dan mengajarkan tentang bagaimana 'membaca' potensi alam dan menuliskannya kembali sebagai tradisi yang diterima secara universal oleh masyarakat, khususnya dalam berarsitektur. Nilai tradisi untuk menselaraskan kehidupan manusia dengan cara menghargai, memelihara dan 
melestarikan alam lingkungan. Hal ini dapat dilihat bahwa semakin adanya penyempurnaan arti dan saling mendukung, yang intinya adalah memahami bakat dan potensi alam tempatnya hidup; dan diwujudkannya sebagai tradisi.

Menurut Putu Oka Ngakan dalam Andi M. Akhmar dan Syarifudin (2007) kearifan local merupakan tata nilai atau perilaku hidup masyarakat lokal dalam berinteraksi dengan lingkungan tempatnya hidup secara arif. Maka dari itu kearifan lokal tidaklah sama pada tempat dan waktu yang berbeda dan suku yang berbeda. Perbedaan ini disebabkan oleh tantangan alam dan kebutuhan hidupnya berbeda-beda, sehingga pengalamannya dalam memenuhi kebutuhan hidupnya memunculkan berbagai sistem pengetahuan baik yang berhubungan dengan lingkungan maupun sosial. Sebagai salah satu bentuk perilaku manusia, kearifan lokal bukanlah suatu hal yang statis melainkan berubah sejalan dengan waktu, tergantung dari tatanan dan ikatan sosial budaya yang ada di masyarakat.

Sementara itu Keraf (2002) menegaskan bahwa kearifan lokal adalah semua bentuk pengetahuan, keyakinan, pemahaman atau wawasan serta adat kebiasaan atau etika yang menuntun perilaku manusia dalam kehidupan di dalam komunitas ekologis. Semua bentuk kearifan lokal ini dihayati, dipraktekkan, diajarkan dan diwariskan dari generasi ke generasi sekaligus membentuk pola perilaku manusia terhadap sesama manusia, alam maupun gaib.

Selanjutnya Francis Wahono (2005) menjelaskan bahwa kearifan lokal adalah kepandaian dan strategi-strategi pengelolaan alam semesta dalam menjaga keseimbangan ekologis yang sudah berabad-abad teruji oleh berbagai bencana dan kendala serta keteledoran manusia. Kearifan local tidak hanya berhenti pada etika, tetapi sampai pada norma dan tindakan dan tingkah laku, sehingga kearifan lokal dapat menjadi seperti religi yang memedomani manusia dalam bersikap dan bertindak, baik dalam konteks kehidupan sehari-hari maupun menentukan peradaban manusia yang lebih jauh.

Definisi kearifan lokal secara bebas dapat diartikan nilai-nilai budaya yang baik yang ada di dalam suatu masyarakat. Hal ini berarti, untuk mengetahui suatu kearifan lokal di suatu wilayah maka kita harus bisa memahami nilai- 
nilai budaya yang baik yang ada di dalam wilayah tersebut. Kalau mau jujur, sebenarnya nilai-nilai kearifan lokal ini sudah diajarkan secara turun temurun oleh orang tua kita kepada kita selaku anak-anaknya. Budaya gotong royong, saling menghormati dan tepa salira merupakan contoh kecil dari kearifan lokal.

Dari definisi-definisi itu, kita dapat memahami bahwa kearifan lokal adalah pengetahuan yang dikembangkan oleh para leluhur dalam mensiasati lingkungan hidup sekitar mereka, menjadikan pengetahuan itu sebagai bagian dari budaya dan memperkenalkan serta meneruskan itu dari generasi ke generasi. Beberapa bentuk pengetahuan tradisional itu muncul lewat cerita-cerita, legenda-legenda, nyanyian-nyanyian, ritual-ritual, dan juga aturan atau hukum setempat.

Kearifan lokal menjadi penting dan bermanfaat hanya ketika masyarakat lokal yang mewarisi sistem pengetahuan itu mau menerima dan mengklaim hal itu sebagai bagian dari kehidupan mereka. Dengan cara itulah, kearifan lokal dapat disebut sebagai jiwa dari budaya lokal. Hal itu dapat dilihat dari ekspresi kearifan lokal dalam kehidupan setiap hari karena telah terinternalisasi dengan sangat baik. Tiap bagian dari kehidupan masyarakat lokal diarahkan secara arif berdasarkan sistem pengetahuan mereka, dimana tidak hanya bermanfaat dalam aktifitas keseharian dan interaksi dengan sesama saja, tetapi juga dalam situasi-situasi yang tidak terduga seperti bencana yang datang tiba-tiba.

\section{B. Tipe-Tipe Kearifan Lokal}

Kearifan lokal adalah persoalan identitas. Sebagai sistem pengetahuan lokal, ia membedakan suatu masyarakat lokal dengan masyarakat lokal yang lainnya. Perbedaan itu dapat dilihat dari tipe-tipe kearifan lokal yang dapat ditelusuri:

1. Kearifan lokal dalam hubungan dengan makanan: khusus berhubungan dengan lingkungan setempat, dicocokkan dengan iklim dan bahan makanan pokok setempat. Contoh: Sasi laut di Maluku dan beberapa tempat lain sebagai bagian dari kearifan lokal dengan tujuan agar sumber pangan masyarakat dapat tetap terjaga 
2. Kearifan lokal dalam hubungan dengan pengobatan: untuk pencegahan dan pengobatan.

Contoh: Masing-masing daerah memiliki tanaman obat tradisional dengan khasiat yang berbeda-beda.

3. Kearifan lokal dalam hubungan dengan sistem produksi: Tentu saja berkaitan dengan sistem produksi lokal yang tradisional, sebagai bagian upaya pemenuhan kebutuhan dan manajemen tenaga kerja.

Contoh: Subak di Bali; di Maluku ada Masohi untuk membuka lahan pertanian, dll.

4. Kearifan lokal dalam hubungan dengan perumahan: disesuaikan dengan iklim dan bahan baku yang tersedia di wilayah tersebut

Contoh: Rumah orang Eskimo; Rumah yang terbuat dari gaba-gaba di Ambon, dll.

5. Kearifan lokal dalam hubungan dengan pakaian: disesuaikan dengan iklim dan bahan baku yang tersedia di wilayah itu.

6. Kearifan lokal dalam hubungan sesama manusia: sistem pengetahuan lokal sebagai hasil interaksi terus menerus yang terbangun karena kebutuhan-kebutuhan di atas. Contoh: Hubungan Pela di Maluku juga berhubungan dengan kebutuhan-kebutuhan pangan, perumahan, sistem produksi dan lain sebagainya

\section{Fungsi Kearifan Lokal}

Setidaknya ada enam signifikasi serta fungsi sebuah kearifan lokal. Diantaranya :

1. Sebagai penanda identitas sebuah komunitas.

2. Elemen perekat (aspek kohesif) lintas warga, lintas agama dan kepercayaan.

3. Kearifan lokal tidak bersifat memaksa atau dari atas (top down), tetapi sebuah unsur kultural yang ada dan hidup dalam masyarakat. Karena itu, daya ikatnya lebih mengena dan bertahan.

4. Kearifan lokal memberikan warna kebersamaan bagi sebuah komunitas.

5. Local wisdom akan mengubah pola pikir dan hubungan timbal balik individu dan kelompok dengan meletakkannya di atas common ground/ kebudayaan yang dimiliki. 
6. Kearifan lokal dapat berfungsi mendorong terbangunnya kebersamaan, apresiasi sekaligus sebagai sebuah mekanisme bersama untuk menepis berbagai kemungkinan yang meredusir, bahkan merusak, solidaritas komunal, yang dipercayai berasal dan tumbuh di atas kesadaran bersama, dari sebuah komunitas terintegrasi.

Keenam fungsi kearifan lokal yang diurai di atas menegaskan pentingnya pendekatan yang berbasis pada nilainilai atau kearifan lokal (local wisdom), dimana sumbersumber budaya menjadi penanda identitas bagi kelangsungan hidup sebuah kelompok maupun aliran kepercayaan.

\section{Contoh-contoh nyata Kearifan Lokal di dalam sebuah masyarakat}

1. Kearifan Lokal di Bengkulu

Ada beberapa etnik yang bersinggungan langsung dengan alam diantaranya etnik Rejang dan Serawaiyang. Etnik Rejang memiliki kearifan dengan mengetahui zonasi hutan, mereka sudah menentukan imbo lem (hutan dalam), imbo u'ai (hutan muda) dan penggea imbo (hutan pinggiran). Dengan zonasi yang mereka buat, maka ada aturan-aturan tentang penanaman dan penebangan kayu. Hampir mirip dengan Etnik Rejang, Serawai yang dikenal sebagai tipikal masyarakat peladang telah mengembangkan kearifan lokal dalam pembukaan ladang yaitu "celako humo" atau "cacat humo", dimana dalam pembukaan ladang mereka melihat tandatanda alam dulu sebelum membuka ladang dimana ada 7 pantangan yaitu:

a. ulu tulung buntu, dilarang membuka ladang di hutan tempat mata air

b. sepelancar perahu

c. kijang ngulangi tai

d. macan merunggu

e. sepit panggang

f. bapak menunggu anak

g. dan nunggu sangkup

tujuh pantangan ini jika dilanggar akan berakibat alam dan penunggunya (makhluk gaib) akan marah dan menebar penyakit. 


\section{Kearifan Lokal di Yogyakarta}

Pernah mendengar Gunung Kidul? Pasti bayangan kita langsung kekeringan. Benar saja, salah satu keunikan Gunung Kidul adalah kawasan Karst. Tetapi harus kita ingat bahwa kawasan ini telah dihuni selama berabad-abad oleh masyarakatnya bahkan dari zaman batu. Munculnya peradaban manusia yang berkembang pada kawasan ini menggambarkan bahwa masyarakat di kawasan ini telah dapat beradaptasi dengan kekeringan. Air menjadi sangat berharga di kawasan ini. Apakah tidak ada sumber air di kawasan ini? Oh kita jangan salah, kawasan ini memiliki sungai bawah tanah yang banyak sekali tetapi karena merupakan kawasan karst agak sulit untuk menaikkan air karena kedalamannya dan juga tipikal kawasan karst. Masyarakat di kawasan ini melakukan pemeliharaan cekungan-cekungan (sinkhole), mereka memodifikasi bagaimana cekungan ini sebagai tabungan air mereka dengan menata batu dan menanami tanaman seperti jarak dan jati di sekitar bibir cekungan. Batu sebagai penyaring, sementara tanaman sebagai penyimpan air. Selain itu juga para penduduk juga menampung air ketika musim hujan tiba sebagai tabungan air ketika kemarau datang.

\section{Kearifan Lokal Kediri}

Cerita Panji mungkin bukan hal yang asing lagi terutama di tanah Jawa Timur. Cerita Panji adalah harta karun yang dimiliki Jawa Timur, lahir di Kediri berkembang sejak zaman Majapahit. Salah satu dongeng Panji adalah Enthit yang terkait dengan pertanian. Cerita semacam Enthit itu memberikan inspirasi mengapa timun dapat ditanam sampai mentheg-mentheg (gemuk dan menyenangkan). Mengapa berbagai sayuran itu tumbuh subur dan menyehatkan. Bagaimana petani pada masa itu memperlakukan lahannya. Bagaimana cara bercocok tanam, semuanya seolah-olah diserahkan pada kekuasaan alam belaka. Semuanya dilakukan dengan cara organik. Konsep pertanian dalam budaya Panji adalah soal tantra atau kesuburan. Jadi bagaimana memperlakukan tanah (lahan) seperti menyayangi istri dan ini hubungannya dengan konservasi alam

4. Kearifan Lokal di Sumatera Utara

Sumatera Utara memiliki sekelompok masyarakat yang dikenal sebagai Parmalim berpusat di Hutatinggi, 
Kecamatan Laguboti, Kabupaten Toba Samosir. Parmalim menekankan lingkungan hidup pada dasarnya memberi dukungan terhadap kelangsungan hidup manusia, maka sewajarnya manusia juga memberi dukungan terhadap lingkungan hidup. Air adalah sumber kehidupan, maka kita harus memberi dukungan terhadap semua hal yang berkaitan dengan pelestarian air. Pada saat menebang pohon, maka bisa dilakukan jika sebelumnya sudah cukup banyak menanam tunas baru, selain itu aturan penebangan juga dengan cara bahwa penebang tidak boleh merobohkan pohon besar sampai menimpa anak pohon lain, jika terjadi maka penebang harus diganti orang lain. Selain itu juga dalam memetik umbiumbian yang menjalar, umat Parmalim harus menyisakan tunas sehingga bisa tumbuh kembali.

\section{E. Tantangan Kearifan Lokal}

1. Jumlah Penduduk

Pertumbuhan penduduk yang tinggi akan mempengaruhi kebutuhan pangan dan berbagai produksi lainnya untuk mencukupi kebutuhan manusia. Robert Malthus menyatakan bahwa penduduk yang banyak merupakan penyebab kemiskinan, hal ini terjadi karena laju pertumbuhan penduduk yang mengikuti deret ukur tidak akan pernah terkejar oleh pertambahan makanan dan pakaian yang hanya mengikuti deret hitung (Soerjani dkk, 1997:99). Adanya kebutuhan pangan yang tinggi menuntut orang untuk meningkatklan produksinya guna mencukupi kebutuhan tersebut, sehingga melakukan modernisasi pertanian dengan melakukan revolusi hijau. Dalam Revolusi hijau dikembangkan penggunaan bibit unggul, pemupukan kimia, pengendalian hama penyakit dengan obat-obatan, pembangunan saluran irigasi secara besar-besaran untuk pengairan dan penggunaan teknologi pertanian dengan traktor untuk mempercepat pekerjaan.

Sebagai akibat pelaksanaan revolusi hijau yang menekankan pada tanaman padi secara monokultur dengan bibit unggul maka akan mempengaruhi kehidupan petani lokal dalam menggunakan bibit lokal yang sebenarnya mempunyai ketahanan terhadap hama dan penyakit, pupuk kandang dan pupuk organik yang digantikan dengan pupuk kimia, penggunaan hewan untuk membajak yang digantikan 
traktor, penggunaan obat-obatan dari tanaman untuk pertanian dengan obat-obatan kimia. Melalui program pemerintah ini, petani nampak hanya sebagai obyek, mereka tunduk patuh pada kehendak penguasa sehingga hak petani untuk mengekspresikan sikap dan kehendaknya terabaikan.

2. Teknologi Modern dan Budaya

Perkembangan teknologi dan ilmu pengetahuan yang cepat menyebabkan kebudayaan berubah dengan cepat pula. Selanjutnya Su Ritohardoyo (2006:42) menjelaskan bahwa perubahan yang terjadi pada masyarakat yang kebudayaannya sudah maju atau kompleks, biasanya terwujud dalam proses penemuan (discovery), penciptaan baru (invention), dan melalui proses difusi (persebaran unsur-unsur kebudayaan). Perkembangan yang terwujud karena adanya inovasi (discovery maupun invention) dan difusi inovasi mempercepat proses teknologi, industrialisasi dan urbanisasi. Ketiga komponen tersebut secara bersama menghasilkan proses modernisasi dalam suatu masyarakat yang bersangkutan. Teknologi modern secara disadari atau tidak oleh masyarakat, sebenarnya menciptakan keinginan dan harapan-harapan baru dan memberikan cara yang memungkinkan adanya peningkatan kesejahteraan manusia.

Melihat kenyataan tersebut maka mudah dipahami mengapa cita-cita tentang teknologi lokal cenderung diabaikan, karena kebanyakan orang beranggapan bahwa teknologi modern selalu memiliki tingkat percepatan yang jauh lebih dinamis. Menurut Budisusilo dalam Francis Wahono(2005:217) teknologi lokal sebagai penguatan kehidupan manusia sesungguhnya memiliki percepatan yang cukup dinamis, misalnya dalam menciptakan lapangan kerja dan memenuhi kebutuhan dasar. Selain menggusur pengetahuan dan teknologi lokal teknologi modern dan seluruh sistem kelembagaannya juga mempunyai potensi "perusakan seperti pembagian hasil yang timpang, pencemaran lingkungan alam dan perusakan sistem nilai sosial-budaya masyarakat.

Banyak media informasi dan komunikasi dengan gencarnya menawarkan produk berikut gaya hidup, gaya konsumsi, dan berbagai sarana hidup yang dianggap sebagai tolok ukur kemajuan dan kebahagiaan yang belum pernah dijumpai sebelumnya. Budisusilo dalam Francis Wahono 
(2005:218) menjelaskan sebagai akibat perkembangan teknologi produksi yang pesat, baik pada sektor pertanian (bioteknologi dan mekanisasi), sektor industri (manufaktur dan eksplorasi alam), maupun sektor jasa (transportasi, medis, laboratoris, komunikasi dan informasi), masyarakat pun menjadi terbiasa menikmati produk barang dan jasa yang bersifat massif dengan efisiensi teknis, kualitas dan jenis yang sama pada semua belahan bumi. Di samping itu ketersediaan akses pada jaringan pemasaran seperti : hypermarket, supermarket, minimarket bahkan traditional market yang ditopang oleh fasilitas/alat bayar yang mudah dan cepat seperti telemarket, cybermarket telah merubah budaya dan kebiasaan baru sejumlah kalangan masyarakat. Pada gilirannya teknologi modern menjadi "standard produksi bagi pasar dunia" yang mengabaikan kemampuan penguasaan teknologi/pengetahuan keanekaragaman sumberdaya lokal.

Percepatan integrasi tersebut telah seperti meningkatnya jumlah pengangguran, kemiskinan, marginalisasi nilai kemanusiaan, krisis lingkungan, kerusakan dan konflik sumberdaya alam dan lingkungan.

\section{Modal Besar}

Eksploitasi terhadap sumberdaya alam dan lingkungan sekarang ini telah sampai pada titik kritis, yang menimbulkan berbagai masalah lingkungan dan masyarakat. Di samping masalah lingkungan yang terjadi di wilayahwilayah dimana dilakukan eksploitasi sumberdaya alam, sebenarnya terdapat masalah kemanusiaan, yaitu tersingkirnya masyarakat asli (indigenous people) yang tinggal di dalam dan sekitar wilayah eksploitasi baik eksploitasi sumberdaya hutan, sumberdaya laut, maupun hasil tambang. Mereka yang telah turun temurun tinggal dan menggantungkan kehidupannya pada hutan maupun laut, sekarang seiring dengan masuknya modal besar baik secara legal maupun illegal yang telah mngeksploitasi sumberdaya alam, maka kedaulatan dan akses mereka terhadap sumberdaya tersebut terampas.

Fenomena tersebut tidak dapat dilepaskan dari kebijakan pemerintah dalam pengelolaan sumberdaya alam selama ini yang lebih menitikberatkan kepada upaya perolehan devisa Negara melalui eksploitasi sumberdaya alam yang bernilai ekonomis. Besarnya keuntungan yang bias 
diraih diikuti dengan meningkatnya devisa dan daya serap tenaga kerja pada sektor yang bersangkutan, semakin menguatnya legitimasi beroperasinya modal besar di sektor tersebut. Kenyataan ini menunjukkan bahwa kekayaan sumberdaya alam dan hayati yang dimiliki dapat diekstraksi untuk mendapatkan surplus.

Namun demikian di lain pihak, keberhasilan perolehan devisa tersebut harus dibayar mahal dengan rusaknya ekosistem daerah yang bersangkutan dan akan berakibat pada terganggunya ekosistem global. Selanjutnya secara sosial budaya, terjadi konflik kepentingan antara tatanan budaya lokal dan budaya modern yang melekat pada industrialisasi dari sumberdaya alam yang dieksploitasi. Menurut Rimbo Gunawan dkk, (1998:v) persoalan tersebut di satu pihak, yaitu modernisasi melihat bahwa tatanan budaya lokal merupakan hambatan yang harus "dihilangkan" atau "diganti" agar proses pembangunan tidak mendapat gangguan serius dari komunitas lokal, sementara itu masyarakat lokal memandang industrialisasi dari hasil sumberdaya alam yang dieksploitasi sebagai ancaman bagi hak-hak adat mereka terhadap lingkungannya Kejadian-kejadian tersebut khususnya pada sumberdaya hutan diperparah dengan banyaknya pengusaha illegal yang hanya mementingkan keuntungan tanpa mempertimbangkan kerusakan lingkungan yang ditimbulkan, yang juga wujud dari keserakahan.

4. Kemiskinan dan Kesenjangan

Kemiskinan dan kesenjangan merupakan salah satu masalah yang paling berpengaruh terhadap timbulnya masalah sosial. Masalah sosial yang bersumber dari kemiskinan dan kesenjangan atau kesulitan dalam pemenuhan kebutuhan pokok, sering kali tidak berdiri sendiri tetapi saling berkaitan dengan faktor lain. Kemiskinan bukan saja menjadi masalah di Indonesia, tetapi juga di banyak Negara berkembang. Kemiskinan juga mempengaruhi orang bertindak untuk memenuhi kebutuhan dasarnya, meskipun tindakan tersebut kadang bertentangan dengan aturan atau norma-norma yang sudah ada atau pun berkaitan dengan kerusakan lingkungan. 


\section{F. Pelayanan Kesehatan Berbasis Kearifan Lokal}

Bangsa Indonesia merupakan bangsa yang sangat kaya dengan keanekaragaman budaya dan kearifan lokal yang tercermin dalam pikiran, sikap, tindakan dan hasil budaya itu sendiri (budaya material). Produk budaya yang dihasilkan oleh masyarakat Indonesia, sangat beragam, mulai dari pakaian, rumah, kesenian, sampai produk budaya yang berhubungan dengan kesehatan.

Sebagai masyarakat yang kreatif, masyarakat Indonesia yang terdiri dari berbagai suku dan tersebar dalam sebaran geografis di seluruh Indonesia, memiliki banyak sekali produk budaya yang berhubungan dengan kesehatan. Produk budaya yang berhubungan dengan kesehatan ini terwujud dalam bentuk produk obat-obat tradisional yang mereka hasilkan untuk mengatasi permasalahan kesehatan mereka dan dalam bentuk tindakan melalui wujud pengobatan secara tradisional dan dalam wujud penggunaan obat tradisional. UU No. 36 tahun 2009 bab VI pasal 59 mengatakan bahwa berdasarkan cara pengobatannya pelayanan kesehatan tradisional terbagi menjadi pelayanan kesehatan tradisional yang menggunakan keterampilan dan pelayanan kesehatan tradisional yang menggunakan ramuan.

Dalam bentuk tindakan melalui wujud pengobatan secara tradisional, adabanyak tindakan-tindakan yang dimiliki oleh masyarakat Indonesia dalam mengatasi permasalahan kesehatan yang mereka hadapi sebagai wujud kearifan lokal. Sebut misalnya kebiasaan melakukan pijat urut untuk menyembuhkan penyakit yang disebabkan karena kurang berfungsinya urat-urat dalam tubuh kita (masyarakat sering menyebutnya dengan salah urat). Pijat yang merupakan cara pengobatan tradisional ini juga dilakukan oleh masyarakat untuk mengatasi permasalahan ketika seseorang keseleo atau patah tulang akibat jatuh dari pohon, tergelincir atau kecelakaan.

Selain tindakan pengobatan tradisional, ada pula produk budaya yang berwujud obat-obatan, dapat kita temukan dihampir semua daerah yang ada di Indonesia sebagai produk budaya dari masyarakat setempat. Obat-obatan tradisional yang diproduksi oleh masyarakat yang ada dibeberapa daerah di Indonesia itu sangat beragam. Masyarakat di suatu daerah tertentu memiliki obat tradisional yang berbeda dengan 
masyarakat dari daerah yang lain. Keanekaragaman hayati yang terdapat dilingkungan tempat mereka hidup serta kearifan lokal yang mereka miliki, menjadi salah satu penyebab munculnya bermacam-macam produk budaya dalam bentuk obat tradisional. Keanekaragaman hayati yang ada dilingkungan sekitar hidup masyarakat Indonesia, menjadi sumber alam yang sangat potensial untuk membuat obat-obat tradisional yang mampu menyelesaikan permasalahan kesehatan mereka. Beberapa contoh obat tradisional yang dimiliki oleh masyarakat Indonesia tersebut misalnya, Kencur yang sering digunakan untuk mengobati sakit batuk. Kencur yang sudah dihancurkan, kemudian diambil airnya untuk diminum. Dibeberapa daerah, masyarakat menggunakan daun jambu yang ditumbuk dan dihancurkan, kemudian diambil airnya untuk mengobati diare.

Di papua, masyarakat papua menggu nakan Zodia (Ewdia suaueolen) yangmerupakan tanaman perdu untuk mengusir nyamuk malaria. Thnaman perdu yangberasal dari Papua ini bisa mengusir nyamuk, baik di dalam ruangan maupun dipekarangan. Menurut pendapat beberapa peneliti, hal ini disebabkan karena tanaman ini menghasilkan aroma yang cukup tajem yang berasal dari kandungan eaodiamine dan rutaecarpine yang tidak disukai oleh seranggal. Masyarakat Papua sudah lama menggunakan tanaman ini untuk menghindari nyamuk malaria, dengan cara mengoleskan tanaman ini pada tubuh mereka.

Di Jawa, tanaman Thpak Dara (Catharanthus roseus L.G. Don) dapat juga digunakan untuk mengobati penyakit. Semua bagian tanaman tapak dara bisa digunakan untuk membuat ramuan obat. IJmumnya tanaman Thpak Dara dapat digunakan untuk mengobati penyakit diabetes, hipertensi, leukemia, mengobati luka baru, obat bengkak dan obat bisul. Hanya saja yang perlu diingat ketika menggunakan tanaman ini untuk pengobatan adalah tanaman ini sedikit bersifat toksik. Artinya, penggunaan untuk ramuan obat ini harus dibatasi. Dosisnya cukup lima bunga atau lima lembar daun.

Ada beberapa alasan yang dapat diamati berkaitan dengan alasan mengapa masyarakat Indonesia masih adayang menggunakan obat tradisional untuk mengobatipenyakit. Pertama, obat-obatan tradisional bebas dari bahan kimia. Hal 
ini dapadilihat mulai dari proses pemetikan tanaman, proses pengolahannya hingga padaproses konsumsinya. Obat-obatan tradisional tidak bisa kita sangkal kekuatannya yakni tidak mengandung bahan kimia sedikitpun. Kedua, obat tradisional memiliki efek samping relatif kecil bila digunakan secara benar dan tepat. Obat tradisiona akan bermanfaat dan aman jika digunakan dengan tepat, baik takaran, waktu dan cara penggunaan, pemilihan bahan serta penyesuai dengan indikasi tertentu. Ketiga, dal,am suatu ramuan obat tradisional umumnya juga terdiri dari beberapa jenis tanaman obat yang memiliki efek saling mendukung satu sama lain untuk mencapai efektivitas pengobatan.

Artinya, tanaman obat tersebut bersifat saling melengkapi atau komplementer. Keempat, obat tradisional cocok untuk penyakitpenyakit metabolik dan degeneratif. Yang termasuk penyakit metabolik diantaranya diabetes (kecing manis), hiperlipidemia (kolesterol tinggi), asam urat, batu ginjal dan hepatitis; sedangkan yang termasuk penyakit degeneratif diantaranya : rematik (radang persendian), asma (sesak nafas), ulser (tukak lambung), haemorrhoid (ambaien/wasir) dan pikun (lost ofmetnory). untuk menanggulangi penyakitpenyakit tersebut, diperlukan pemakaian obat dalam waktu lama sehinga jika mengunakan obat modern dikhawatirkan adanya efek samping yang terakumulasi dan dapat merugikan kesehatan. Oleh karena itu lebih sesuai bila menggunakan obat alam atau obat tradisional, walaupun penggunaanya dalam waktu lama namun efek samping yang ditimbulkan relatif kecil sehingga dianggap lebih aman. Alasan-alasan inilah yang kadang membuat masyarakat Indonesia bersikukuh untuk menggunakan obat tradisional.

Disatu sisi, kearifan lokal masyarakat Indonesia yang teraplikasi dalam bentukobat dan pengobatan tradisional ini memang menjadi kekayaan budaya masyarakat Indonesia. Bukan hanya budaya, tetapi sudah terbukti membantu mengatasi permasalahan kcsehatan yang dialami masyarakat Indonesia selama bertahun-tahun.Tetapi disisi yang lain, ada beberapa cara pengobatan tradisional serta obat-obat tradisional yang dimiliki masyarakat Indonesia dan digunakan untuk mengatasi permasalahan kesehatan ini seringkali membahayakan kesehatan mercka dan tidak jarang membawa korban jiwa. 
Sebagai contoh, di beberapa desa dan beberapa daerah di Indonesia yang belum memiliki akses yang cukup dengan layanan kesehatan, banyak sekali ibuibu yang melahirkan dengan bantuan dukun bcranak. Biasanya dukun beranak ini menggunakan peralatan yang sangat sederhana dan kadangkadang tidak steril ketika membantu persalinan, Untuk memotong tali pusar sang bayi misalnya, biasanya dukun beranak menggunakan sebilah bambu yang sudah ditipiskan dan diruncingkan (sering disebut 'welar' untuk mcmotong tali pusar sang bayi), Yang menjadi permasalahan, seringkali caru yang digunakan oleh dukun bayi ini justru membahayakan bagi ibu yang melahirkan dan juga bagi bayi yang dilahirkan. Hal ini disebabkan karena pcralatan yang digunakan oleh dukun beranak (bambu tipis yang sudah diruncingkan tadi) belum tentu steril, sehingga tidak jarang tindakan medis yang dilakukan oleh sang dukun bayi ini justru membawa pada kematian.

Yang mengejutkan, keputusan ibu-ibu untuk meminta bantuan dukun beranak ini bukan hanya disebabkan oleh alses kesehatan yang rendah, tetapi sering kali justru disebabkan karena rasa percaye dan kenyamanan mereka dengan dukun beranak dibandingkan dengan bidan atau dokter. Akibatnya, kebiasaan sebagian masyarakat Indonesia yang melahirkan dengan bantuan dukun bayi ini masih susah untuk diubah. Masih banyak masyarakat di Indonesia, rerutama yang ade di daerahdaerah tetap lebih suka menggunakan bantuan dukun beranak untuk membantu proses persalinan dibandingkan dengan bantuan dokter atau bidan. Alasan bahwa mereka lebih kenal dengan dukun bayi dan lebih nyaman dengan dukun menjadi satu alasan yang seringkali dilontarkan ketika mereka rerap mempertahankan proses pengobatan dengan menggunakan cara tradisional ini. Sementara, pengobatan modern yang dilakukan melalui dokter dan paramedic belum sepenuhnya bisa diterima oleh masyarakat. Rasa asing dan ketidakpe rcayaan terhadap dokter dan paramedis menjadi alasan kuat yang sering kali digunakan oleh masyarakat. Selain alasan diatas, masyarakat sering menggunakan asumsi kekuatan pengobatan dan obat tradisional untuk menolak pengobatan modern.

Ada banyak buktiyangdiberikan oleh masyarakat sehubungan dengan kekuatan obat tradisional dan 
pengobatan tradisional dibandingkan dengan pengobatan secara modern. Dalam pandangan beberapa masyarakat Indonesia, obat tradisional dianggap lebih ampuh dibandingkan dengan obat modern. Misalnya, ada sebagian masyarakat yang menganggap bahwa cara Papua menggunakan darn Zodia (Euodia suaueolen), dianggap lebih ampuh dibandingkan dengan lotion anti nyamuk yang beredar pada saat ini.

\section{G. Pelayanan Kesehatan Berbasis Kearifan Lokal Melalui Pengobatan Tradisional}

\section{Pengobatan tradisional merupakan kearifan lokal}

Menurut Badan Kesehatan Dunia (WHO), sebanyak 80\% dari total populasi di benua Asia dan Afrika bergantung pada pengobatan tradisional. WHO juga telah mengakui pengobatan tradisional dapat mengobati berbagai jenis penyakit infeksi, penyakit akut, dan penyakit kronis. Misalnya, tanaman qinghaosu (yang mengandung artemisinin) sebagai obat antimalaria yang telah digunakan di China sejak 2.000 tahun yang lalu.25 Dalam dua dasawarsa terakhir, perhatian dunia terhadap obat-obatan dari bahan alam (obat tradisional) menunjukkan peningkatan, baik di negara-negara berkembang maupun di Negara-negara maju. Badan Kesehatan Dunia (WHO) menyebutkan bahwa hingga 65\% dari penduduk negara-negara maju telah menggunakan pengobatan tradisional dimana didalamnya termasuk penggunaan obatobat bahan alam. Menurut data Secretariat Convention on Biological Diversity, pasar global obat bahan alam mencakup bahan baku pada tahun 2000 mencapai nilai US\$ 43 milyar.26 Hal ini membuktikan bahwa tidak hanya Indonesia saja yang masih menggunakan pengobatan tradisional tetapi juga negara adidaya lainnya masih kental dengan budaya pengobatan tradisionalnya. Dasar hukum dari pengobatan tradisional adalah Keputusan Menteri Kesehatan Republik Indonesia Nomor 1073/MENKES/SK/VII/2003 tentang Penyelenggaraan Pengobatan Tradisional. Pada keputusan menteri kesehatan tersebut, pengobatan tradisional mempunyai arti yaitu "pengobatan dan/atau perawatan dengan cara, obat dan pengobatnya mengacu kepada pengalaman, keterampilan turun menurun, dan/atau 
pendidikan/pelatihan, dan diterapkan sesuai dengan norma yang berlaku dalam masyarakat".

Diakuinya pengobatan tradisional di Indonesia dikarenakan oleh banyak hal, yang salah satunya adalah dalam kehidupan bermasyarakat khususnya dalam bidang pengobatan, masyarakat cenderung menggunakan obatobatan kimia farmasi. Obat-obatan kimia tersebut memiliki efek samping ringan sampai berat, bahkan dapat menyebabkan dampak yang fatal. Selain itu harga dari obatobatan kimia juga relatif mahal dibanding obat-obatan tradisional. Kehidupan masyarakat zaman dahulu dalam hal pengobatan terkenal lebih alami dan jauh dari modernisasi. Masyarakat zaman dahulu menggunakan obat-obatan herbal yang didapat dari lingkungan alam sekitar berupa tanaman, alat, ataupun budaya spiritualnya. Obat tradisional adalah bahan atau ramuan bahan yang berupa bahan tumbuhan, bahan hewan, bahan mineral, sediaan sarian (galenik), atau campuran dari bahan tersebut yang secara turun temurun telah digunakan untuk pengobatan, dan dapat diterapkan sesuai dengan norma yang berlaku di masyarakat.28 Salah satu metode pengobatan seperti itu kemudian kita kenal sebagai pengobatan tradisional. Sebagai bukti kemajuan budaya, peradaban dan kearifan lokal bangsa Indonesia di masa lalu, pengobatan tradisional seharusnya dapat terus dijaga dan dilestarikan oleh negara.

Pengobatan tradisional merupakan pengetahuan, dan strategi kehidupan masyarakat lokal yang berupa aktivitas masyarakat lokal tersebut untuk menjawab berbagai masalah kesehatan dan pengobatan dalam rangka pemenuhan kebutuhan hidupnya, sekaligus memelihara kebudayaan dan peradabannya. Kearifan lokal disini adalah kebijakan daerah (lokal) yang sekiranya bijaksana demi kepentingan bersama. Dengan adanya pengobatan

tradisional yang efek dan khasiatnya telah teruji waktu dan dapat diuji secara ilmiah, pengobatan tradisional seharusnya juga dapat diberikan status yang sama dengan pengobatan medis konvensional dalam hal pelayanan kesehatan masyarakat. Mengingat banyaknya keuntungan dan kelebihan dari pengobatan tradisional itu sendiri, maka apabila negara menjamin, mengatur, dan menjaga pengobatan tradisional sebagai salah satu bentuk pelayanan kesehatan, 
maka negara dapat dikatakan telah menyelenggarakan pelayanan kesehatan yang berbasis kearifan lokal.

\section{Pengobatan tradisional dalam perundang-undangan}

Menurut angka 16 Pasal 1 Undang-Undang Nomor 36 Tahun 2009 tentang Kesehatan, pelayanan kesehatan tradisional adalah pengobatan dan/atau perawatan dengan cara dan obat yang mengacu pada pengalaman dan keterampilan turun temurun secara empiris yang dapat dipertanggung jawabkan dan diterapkan sesuai dengan norma yang berlaku di masyarakat. Pengobatan tradisional sebagai bentuk pelayanan kesehatan disamping pengobatan medis konvensional juga memiliki ragam jenisnya. Jenis-jenis pengobatan tradisional tersebut saat ini telah banyak sekali dikenal dan diterapkan oleh berbagai kalangan masyarakat. Pengobatan tradisional diklasifikasikan berdasarkan pada jenis-jenis pengobat tradisional. Pengobat tradisional adalah orang yang melakukan pengobatan tradisional.

Banyak jenis ragam pengobat tradisional yang ada dalam masyarakat dan diatur oleh hukum positif melalui ketentuan yang tertera dalam peraturan perundangundangan tersebut mengindikasikanbahwa pelayanan kesehatan melalui pengobatan tradisional merupakan suatu bentuk pelayanan kesehatan yang diakui dan difasilitasi oleh hukum di negara Indonesia. Namun bila kita melihat pada jenis-jenis pengobat tradisional tersebut, maka untuk penerapan pengobatan tradisional pada suatu instansi resmi seperti halnya rumah sakit umum daerah (RSUD), jenis-jenis pengobat tradisional tidak dapat diterapkan seluruhnya. Pengobatan tradisional yang dapat diterapkan pada pelayanan kesehatan di Instansi kesehatan resmi terdiri dari jenis pengobat tradisional dengan pendekatan keterampilan dan ramuan. Pembatasan penerapan pengobatan tradisional yang dapat dilaksanakan pada instansi kesehatan resmi tersebut dikarenakan bahwa pelayanan kesehatan harus dilaksanakan secara aman, bermanfaat, dan ilmiah.

Ketika pengobatan tradisional dengan pendekatan agama dan supranatural belum dapat di integrasikan dalam pelayanan kesehatan, maka negara dalam hal ini tetap harus melaksanakan fungsi kontrol terhadap pelaksanaan pengobatan tradisional dengan pendekatan-pendekatan tersebut. 


\section{Legalisasi Pengobatan tradisional}

Pengobatan tradisional dapat berperan sebagai salah satu bentuk kebijakan pemerintah daerah yang berbasis kearifan lokal demi terciptanya kesejahteraan masyarakat. Dalam pelaksanaan kebijakan pelayanan kesehatan melalui pengobatan tradisional, pemerintah daerah juga harus menyusun regulasi yang relevan dengan konteks kebijakan tersebut demi terwujudnya kesejahteraan masyarakat di daerahnya. Penyelenggaraan kebijakan pelayanan kesehatan melalui pengobatan tradisional juga harus mempunyai dasar hukum di setiap tingkatan yang menjamin terwujudnya asas kepastian, keadilan dan juga kemanfaatan. Penyelenggaraan dari pengobatan tradisional dimulai dari perizinan.

Sebagai pelaksanaan dari hal tersebut, seluruh pengobat tradisional di Indonesia harus melampaui beberapa tahapan untuk mendapatkan pengakuan dan legalisasi dari pemerintah. Tahap pertama adalah melalui perizinan yang berfungsi untuk memperoleh Surat Terdaftar Pengobat Tradisional dengan cara mendaftarkan dirinya ke Kepala Dinas Kesehatan Kabupaten/Kota. Surat Terdaftar Pengobat Tradisional yang selanjutnya disebut STPT adalah bukti tertulis yang diberikan kepada pengobat tradisional yang telah melaksanakan pendaftaran. STPT dikeluarkan oleh Kepala Dinas Kesehatan Kabupaten/Kota selambat-lambatnya satu bulan setelah permohonan dan seluruh kelengkapan dipenuhi. Kewajiban bagi seluruh pengobat tradisional itu diatur dalam Pasal 4 ayat 1 serta tata cara dan persyaratan mendapatkan Surat Terdaftar Pengobat Tradisional diatur dalam Pasal 5 KMK Nomor 1076/Menkes/Sk/Vii/2003 tentang Penyelenggaraan Pengobatan Tradisional.

Setelah pengobat tradisional memiliki STPT, pengobat tradisonal dapat diberikan Surat Izin Pengobat Tradisional. Surat Izin Pengobat Tradisional (SIPT) adalah bukti tertulis yang diberikan kepada pengobat tradisional yang metodenya telah dikaji, diteliti dan diuji terbukti aman dan bermanfaat bagi kesehatan.32 Tata cara dalam mendapatkan SIPT diatur jelas di dalam pasal 11 Keputusan Menteri Kesehatan Nomor 1076/Menkes/Sk/Vii/2003 tentang Penyelenggaraan Pengobatan Tradisional.

Sebagai tindak lanjut dari diakuinya pengobatan tradisional dalam perundang-undangan dan juga sistem 
pelayanan kesehatan di Indonesia, pemerintah juga telah mengakomodir pengembangan pengobatan tradisional dalam suatu institusi yaitu Sentra Pengembangan dan Penerapan Pengobatan Tradisional (Sentra P3T). Sentra P3T adalah unit yang dibentuk pemerinah untuk melakukan penelitian/ pengkajian/ pengujian pengobatan tradisional. Pengobatan tradisional penting untuk dilakukan penelitian guna didapat pembuktian secara ilmiah menjadi pengobatan tradisional yang aman dan bermanfaat sehingga dapat diterapkan di fasilitas kesehatan sebagai pengobatan alternatif dan komplementer. Fungsi lainnya dari Sentra P3T yaitu pelayanan kesehatan tradisional, institusi pendidikan dan pelatihan pelayanan kesehatan tradisional yang aman serta bermanfaat, menyelenggarakan jaringan informasi dan dokumentasi pelayanan kesehatan tradisional. Sampai dengan tahun 2012 sudah terdapat 33 provinsi yang memiliki Sentra P3T.

\section{Pelaksanaan Upaya Komunikasi Kesehatan}

Pada saat ini, pemerintah mempunyai kepedulian yang sangat besar terhadap kesehatan. Perhatian pemerintah terhadap kesehatan masyarakat Indonesia lebih diwujudkan dalam bentuk usaha pencegahan kesehatan dalam kehidupan masyarakat dengan tujuan supaya masyarakat tidak terlanjur menderita sakit. UU no. 36 tahun 2009 bab VI pasar 47 mengatakan "Upaya kesehatan diselenggarakan dalam bentuk kegiatan dengan pendekatan promotif, preventif, kuratif, dan rehabilitatif yang dilaksanakan secara terpadu, menyeluruh, dan berkesinambungan. Pelaksanaan upaya peningkatan derajat kesehatan dengan pendekatan sosial ini sebetulnya bukan hanya tugas pemerintah, tetapi tugas kita semua. Upaya ini bisa dilakukan oleh semua orang yang terlibat dalam bidang kesehatan maupun merekamereka yang nantinya akan bekerja dan bergelut dalam bidang kesehatan (peserta didik kesehatan).

Usulan pertam aada \ah adanyakurikulum yang berisi b udaya di sekolah-sekolahatau perguruan tinggi bidang kesehatan. Mata kuliah tersebur berisi tentang budayakhususnya kekayaan budaya di Indonesia. Dengan mengetahui tenrang beragam budaya Indonesia, diharapkan bahwa calon para medis dapat memberikan tindakan pengobatan yang tepat kepada penduduk Indonesia sesuai 
dengan latar belakang budayanya tersebut. Selanjutnya, agar dapat memahami budaya yang berbeda-beda ini, maka diusulkan juga perlunya mata kuliah komunikasi lintas budaya. Output mata kuliah komunikasi lintas budaya ini diharapkan dapat membekali calon para

medis untuk dapat berkomunikasi dengan penduduk setempat. Apabila tercipta komunikasi yang baik, maka para medis akan dengan mudah memberikan tindakan perawatan kepada pasien nya. Dar, bahkan akan sangat memungkinkan terjadinya eksplorasi obat-obatan tradisional dan cara pengobatan tradisional yang selama ini mungkin belum diketahui masyarakat luas. Kurikulum berbasis budaya ini menurut penulis, sebenarnya dapat juga

dimasukkan ke dalam mata kuliah penyuluhan kesehatan. Kurikulum berbasis budaya dapat membekali mahasiswa dengan materi sosialisasi kesehatan melalui budaya tradisional dan teknologi komunikasi dengan media yang sederhana. Sosialisasi kesehatan melalui budaya tradisional (kesenian daerah) dalam menyampaikan pesanpesan kesehatan. Peserta didik di pendidikan kesehatan dapat diajarkan menyampaikan pesan-pesan kesehatan dengan menggunakan kesenian daerah dan permainan-permainan tradisional yang ada di daerah tersebut. Sebagai contoh, untuk menyampaikan pesan kesehatan kepada masyarakat salatiga, dapat menggunakan kesenian kuda lumping, wayang maupun permainan-permainan tradisional yang ada di daerah tersebut. Sedangkan sosialisasi keseharan dengan menggunakan teknologi komunikasi, dapat menggunakan handphone. Saat ini, handphone merupakan salah satu bentuk teknologikomunikasiyanghampirdimiliki olehsemualapisanmasyarakat. Handphone dapat diladlkan sebagai alat sosialisasi kesehatan melalui sms yang dikirimkan untuk mempromosikan cara hidup sehat. Handphone juga dapat digunakan untuk membuat videovideo yang dapat digunakan sebagai alat untuk mensosialisasikan cara-cara hidup sehat. 


\section{H. Kearifan Lokal Masyarakat Di Dunia \\ 1. Pengetahuan Kearifan Lokal Berperan Pecahkan Masalah Global}

Aspek kearifan lokal ternyata tidak hanya menjadi suatu tinggalan kebudayaan atau yang bersifat tradisional.

Kearifan lokal ternyata dapat menunjang berbagai ilmu pengetahuan dalam mengatasi berbagai permasalahan di masyarakat. Demikian disampaikan Guru Besar Emeritus Leiden University, Belanda Prof. Dr. L. Jan Slikkerveer saat menjadi pembicara kunci dalam seminar internasional "Indigenous Knowledge for Sustainable Development" yang digelar Universitas Padjadjaran secara virtual, Kamis (10/12).

Ahli Etnobotani ini menjelaskan, modernisasi ternyata memberikan dampak pada menguatnya permasalahan sosial.

Modernisasi menurutnya tidak menjadikan situasi ekonomi dan sosial budaya masyarakat membaik. Kesenjangan sosial justru semakin meningkat.

Dari studi yang sudah dilakukan, Prof. Jan menunjukkan bahwa bentuk praktik dan kelembagaan kearifan lokal di tingkat akar rumput ternyata berperan dalam mengatasi kesenjangan sosial. Sayangnya, dominasi pengetahuan modern kerap mengalahkan eksistensi pengetahuan lokal. "Dominasi pengetahuan global yang membuat pengetahuan lokal terpinggirkan, meskipun memiliki potensi besar," ujar peneliti di Leiden Ethnosystem and Development Programme (LEAD) Leiden University ini.

Peran kearifan lokal tidak hanya untuk pembangunan sosial ekonomi. Sektor pertanian, pengelolaan lingkungan, serta pengembangan kesehatan masyarakat juga perlu sentuhan kearifan lokal. "Meski sering diabaikan, kearifan lokal nyatanya memberikan kunci bagi banyak solusi berkelanjutan," ucapnya.

\section{Pelopor Kajian Kearifan Lokal}

Guru Besar penerima Doktor Honoris Causa dari Unpad tahun 2005 silam ini telah banyak berkecimpung meneliti di bidang etnossins. Beberapa risetnya juga banyak yang berkolaborasi dengan akademisi Unpad. Salah satu kiprahnya bersama Guru Besar FISIP Unpad (alm) Prof. Kusnaka Admiharja adalah mengembangkan pusat kajian etnosains bernama "Indonesian Resource Center for Indigenous Knowledge (Inrik)” di Unpad pada 1994. 
Pendirian pusat kajian ini juga difasilitasi penuh oleh Rektor ke-8 Unpad Prof. Maman P. Rukmana.

Inrik Unpad berfokus pada kajian tentang pengetahuan, adat istiadat, hingga kultur dari masyarakat Indonesia. Pusat kajian tersebut pada saat itu menjadi pusat kajian pertama yang berfokus pada pengembangan kajian budaya lokal di Indonesia. "Semua karya rintisan kajian peneliti Inrik Unpad di bidang etnosains memberikan kontribusi sebagai studi pertama dari kearifan lokal di Indonesia," kata Prof. Jan. Kepala Pusat Pengelolaan Pengetahuan Unpad Wina Erwina, PhD mengatakan, aktivitas Inrik Unpad terus bertahan hingga kini. Eksistensi kajian etnosains di Unpad terus dipertahankan oleh para Rektor Unpad.

Guna mempertahankan eksistensi kajian etnosains, Unpad mulai menerbitkan "Indigenous Knowledge (IK) Journal” pada Januari 2021 mendatang. IK Journal yang dikelola oleh Pusat Pengelolaan Pengetahuan Unpad bersama Inrik Unpad merupakan jurnal internasional open access yang menerbitkan laporan penelitian empiris, tinjauan sistematis, evaluasi program, dan laporan kasus yang berfokus pada komunitas di kawasan budaya.

\section{Kearifan Lokal}

Kearifan lokal menjadi bahan wacana dalam berbagai dimensi kehidupan manusia. Berikut ini bebrapa contoh tentang bangkitan kesadaran terhadap pentingnya kearifan lokal. Akibat industrialisasi yang terus berekspansi secara cepat, terjadilah kerusakan lingkungan. Polusi, banjir, tanah longsor dan pemanasan global (global warning) merupakan byproduct dari industrialisasi, yang bahkan sampai sekarang diyakini oleh para penganut developmentalisme sebagai satusatunya jalan menuju kemajuan dan kesejahteraan umat manusia. Pengunaan bahan bakar, konversi lahan produktif menjadi real estat dan pabrik menyebabkan kesusakan lingkungan. Eksploitasi sumber daya alam atas nama pembangunan ternyata menimbulkan penderitaan di banyak tempat. Itu semua menggambarkan bagaimana parahnya kerusakan lingkungan yang menimbulkan penderitaan masyarakat lokal akibat pembangunan yang tidak berorientasi pada kearifan lokal. 
Contoh lainnya bisa dilihat dalm dimensi hubungan antarmanusia. Dalam tradisi Jawa yang sesungguhnya diwarnai oleh ajaran Islam, manusia diharuskan untuk menjalin silaturrahim. Orang bertemu muka, bercanda, berbincang-bincang dengan keakraban. Mereka memiliki waktu yang longgar untuk bercengkerama sehingga hubungan batin menjadi kuat karena bisa melihat ekspresi teman atau tetangganya. Tetapi, dalam kehidupan modern, akibat teknologi informasi, orang merasa cukup berkomunikasi dengan teknologi informasi, misalnya telepun. Manusia modern telah kehilangan sentuhan-sentuhan keakraban sesama. Tradisi gotong royong di kampung-kampung tradisional sesungguhnya merupakan instituasi untuk menguatkan keakraban dan tanggung jawab sosial. Ada nilainilai (values) yang tidak bisa digantikan oleh sistem baru, misalnya dengan urunan untuk membayar tenaga orang lain untuk mengerjakan tugas-tugas kolektif di suatu komunitas tertentu.

\section{$>$ Keadaban}

Menyadari pentingnya kearifan lokal. Maka tugas kita sekarang ialah menemukan kearifan lokal dan memfungsikannya untuk mengembangkan kehidupan masyarakat yang berkeadaban. Secara sederhana dapat dikatakan bahwa kehidupan masyarakat semacam itu, dalam bahasa rakyat Indonesia, adalah kehidupan yang sejahtera lahir dan batin dan berada bi bawah naungan keampunan Allah (wa rabb ghafur); juga masyarakat yang diberkahi oleh Allah (barakat min al-sama' wa al-ardl); masyarakat yang aman damai (aminan muthma'innan). Masyarakat seperti itu tidak akan lahir secara tiba-tiba, tetapi dari proses yang melibatkan usaha manusia, yang salah satunya ialah pertimbangan terhadap pentingnya kearifan lokal.

Pada masyarakat Jawa, misalnya, kearifan lokal bisa ditemukan dalam kehidupan sehari-hari baik terhadap sesama manusia, hewan, tumbuh-tumbuhan dan alam dalam pengertian yang lebih luas. Dalam hubungan manusia, kita masih menemukan budaya kewajaran (ngono yo ojo ngono), toleransi (tepo seliro), gotong royong, ketulusan, penghormatan terhadap yang lebih tua, termasuk orang tua, guru dan lain-lain. Dalam hubungan dengan hewan, kita menemukan betapa akrabnya manusia denga makhluk Allah 
itu, misalnya tradisi angon wedus (kambing), memelihara sapi di kandang yang dekat dengan rumah. Ini berbeda dengan ternak ayam dalam masyarakat modern yang penuh dengan kekejaman karena ingin memperbesar produksi untuk memenuhi konsumsi masyarakat modern. Dalam hubungnnannya denga alam, masyarakat masih memelihara hubungan yang akrab sehingga tidak melakukan eksploitasi sumber daya alam secara sembrono. Industrialisasi yang tidak memperhatikan kearifan lokal mengakibatkan malapetaka baik bagi masyarakat yang tinggal di sekitar maupun bagi warga dunia dalam jangka panjang.

\section{Budaya dan Kearifan Lokal di Era Global: Pentingnya Pendidikan Bahasa dan Seni Suminto A. Sayuti}

a) Sebagai bangsa, kita memiliki kosa-budaya yang begitu melimpah ruah. Apapun bentuk dan wujudnya, budaya bangsa tersebut merupakan dan menjadi modal dan identitas, benteng, serta sekaligus sebagai "paspor utama," terlebih lagi, dalam tata pergaulan dan tegur-sapa global. Menjadi modal dan identitas karena dengan dan melalui budaya kita dikenal oleh dan memperkenalkan diri kepada bangsa-bangsa lain. Budaya merupakan modal dan identitas kita dalam berelasi dan berinteraksi dengan "yang lain," yang bukan kita, liyan, the others.

Pengakuan bangsa-bangsa lain atas tingginya nilainilai budaya yang kita miliki, misalnya saja, merupakan "paspor," yang melegitimasi bahwa secara kultural kita sah bergaul dan berposisi setara dengan mereka. Sementara itu, proses berelasi dan berinteraksi dengan "yang lain" itu juga meniscayakan masuknya beragam nilai secara tak terhindarkan, yang dalam sejumlah hal acapkali bertentangan dengan nilai-nilai yang sudah lama terinternalisasi dan diyakini. Dalam konteks inilah, nilainilai yang inheren dalam kosa-budaya bangsa berfungsi sebagai benteng. Akan tetapi, yang menjadi persoalan mengapa kecenderungan materialistik dan hedonik makin hari makin mengedepan di tengah kehidupan masyarakat, dan bersamaan dengannya: nilai- nilai dan karakter kebangsaan kita juga terasa kian pudar (untuk tidak mengatakan dalam proses "mulai dilupakan"), padahal kita memiliki modal dan identitas, paspor, serta benteng budaya yang kokoh. Adakah yang 
salah dalam mengelola sistem dan mekanisme kebudayaan dalam konteks kebangsaan kita, dan sederet pertanyaan kultural lain.

Dalam konstelasi seperti dikemukakan di atas, posisi pendidikan bahasa dan seni sebagai "proses pembudayaan" pun layak dipertanyakan: sudahkah ia menunaikan imperatif ideologis, edukatif, dan kultural sebagai fungsi-fungsi utama dalam praksisnya. Terdapat paling tidak empat alasan yang dapat dikemukakan dalam kaitan ini. Pertama, dalam keseluruhan dan keutuhannya, kebudayaan merupakan lahan dan habitat utama bagi persemaian benih-benih karakter, tempat identitas dan kepribadian tumbuh dan berkembang.

Kedua, kebudayaan memerlukan upaya pemeliharaan, pengembangan, dan pemberdayaan melalui, antara lain, pendidikan, utamanya dalam mencerahkan pentingnya norma/nilai, perilaku, dan benda-benda budaya kepada masyarakat. Ketiga, nilainilai luhur budaya bangsa akan menjadi sesuatu yang asing bagi masyarakat apabila praksis pendidikan bahasa dan seni dilepaskan dari bingkai dan orien $\neg$ tasi budaya. Keempat, fungsi kebudayaan sebagai sumber nilai bisa saja lama-kelamaan akan hilang apabila tidak didukung oleh masyarakat yang sadar dan terdidik. Butir-butir ini menunjukkan adanya hubungan resiprokal dan dialektis antara pendidikan bahasa dan seni di satu sisi, dan kebudayaan pada sisi yang lain: sebuah relasi yang penting bagi upaya penggalian dan pengembangan kearifan lokal dalam konteks nation and character building di era global.

b) Masuknya beragam nilai yang berasal dari "luar" (sebagai "pusat") melalui beragam piranti modern, sebagai akibat yang tak terhindarkan dari proses global, telah memberi warna dan corak tersendiri pada sendi-sendi kehidupan budaya bangsa. Derasnya arus global dari pusat ke "pinggiran" antara lain mengakibatkan munculnya situasi "ketertinggalan budaya," dan sangat mungkin, "longsor budaya." Ketertinggalan budaya melanda sebagian besar masyarakat negara berkembang (sebagai "pinggiran") dalam upayanya mencapai strata modernis bersamaan dengan membanjirnya informasi. 
Simbol budaya baru, kadang-kadang, diberi makna tidak pada tempatnya. Teknologi yang berkembang begitu pesat dan canggihnya juga menyebabkan pola komunikasi masyarakat berubah dengan cepat. Pengetahuan dan pengalaman manusia dibentuk oleh berbagai informasi yang dapat disimpan dan ditransmisikan dengan kecepatan yang begitu dahsyat dan dapat menjangkau kawasan yang begitu luas. Bahasa lisan digantikan peranannya oleh citra-citra visual. Sikap utilitarian, materialis, dan hedonis mengedepan berbarengan dengan munculnya pergeseran yang terus-menerus. Akibatnya, pandangan dunia masyarakat pun pecah, tercabik, dan salah-tempat (dislokasi). Ini semua bisa diperhitungkan sebagai tantangan sekaligus ancaman bagi nilai-nilai, karakter, dan identitas bangsa. Proses persemukaan, persinggungan, dan "persetubuhan" budaya yang tengah dan akan terus terjadi tersebut benar-benar akan menjadi sesuatu yang membahayakan apabila di dalam sistem dan mekanisme kebudayaan dalam konteks kebangsaan tidak disediakan ruang, peluang, atau kemungkinan perubahan. Karena apa? Sesuatu akan menjadi langgeng bilamana dirinya terbuka bagi perubahan dan pembaharuan. Dalam hubungan ini, berpikir dan bertindak strategis pun menjadi penting dan mendesak. Perancangan dan pelaksanaan berbagai upaya yang muara akhirnya pada terciptanya kekenyalan identitas bangsa dalam menghadapi dan memasuki berbagai proses tersebut perlu segera dilakukan agar nilai-nilai budaya dapat dirawat selayaknya dan yang mulai pudar akan dapat dicahayakan kembali.

Ketika muncul kesadaran bahwa yang lokal selalu menjadi korban marginalisasi sehingga terpinggirkan, seluruh masyarakat (etnik) yang ada merasa perlu meredefinisi diri sendiri dan budayanya. Memasuki "kandang" budaya lokal, di satu sisi, dapat diperhitungkan sebagai dasar bagi upaya menciptakan situasi sadar budaya bangsa. Hanya saja, tindakan ini bisa saja memunculkan paradoks di sisi lainnya, yakni ketika ia ditafsirkan secara linear bahwa kita akan hidup di masa depan, bukan di masa lalu. Bahkan, ketika proses ini menjadi eksklusif, ia menjadi tantangan tersendiri karena 
yang tercipta bukan lagi kesadaran bersama dalam konteks nation state, melainkan semangat etnonasionalisme.

Oleh karena itu, orientasinya harus diarahkan pada kesejatian fitrah manusia sebagai pelaku yang sadar untuk bertindak mengatasi dunia dan realitas yang (mungkin bisa) memusuhi dan menindasnya, yang secara keseluruhan berada dalam bingkai kebersamaan dengan liyan ("yang lain," the other). Konsekuensinya, sistem dan mekanisme budaya lokal dan translokal tetap harus dipelihara, dikembangkan, dan diberdayakan bersama.

Persilangan dialektis antara liyan dan dorongan untuk mencipta dan mencipta ulang identitas lokal yang independen dalam suatu proses transformasi yang berkesinambungan menjadi imperatif untuk dilaksanakan. Tujuannya adalah menyiapkan sebuah habitat agar figurfigur yang terlibat di dalamnya mampu menghayati nilai lokal, dan sekaligus mampu membuka ruang tegur-sapa dengan liyan dalam dirinya: untuk menjadi lokal sekaligus translokal dan global. Pendek kata, agar masyarakat memiliki kekenyalan budaya yang memadai.

Persoalan nilai lokal dan translokal tersebut memang memunculkan dilema: apakah nilai-nilai yang ada itu diolah secara kreatif (dalam arti didialogkan dengan nilai "yang lain") melalui rekonsiliasi yang seimbang, atau ia dimanfaatkan begitu saja sehingga terjadi homogenisasi nilai dan sekaligus dominasi atas nilai yang lain melalui melalui rekonsiliasi subordinasi.

Yang jelas, upaya apapun yang dipilih dan dilakukan hendaknya tidak terjebak menjadi upaya penghapusan melalui rekonsiliasi eliminasi. Kebijakan apapun yang diambil dan mengatasnamakan kepentingan publik, karenanya, kebijakan itu harus selalu didasarkan pada wawasan kultural. Situasi polifonik dan multikultural harus menjadi dasar utamanya. Implikasinya, habitat budaya kewargaan yang sehat harus disiapkan, yakni suatu habitat yang meniscayakan tersedianya ruang dan peluang bagi partisipasi penuh dan interaksi yang terbuka bagi semua unsur masyarakat yang beragam. 
Hal tersebut penting karena mereka yang tetap menghayati nilai-nilai budaya lokalnya dikhawatirkan akan menjadi kaum marginal yang kurang dimunculkan dalam konstelasi informasi translokal dan global, dan seringkali kurang diuntungkan secara material. Oleh karena itu, upaya membangun kesadaran terhadap adanya kearifan lokal sebagai sebuah realitas budaya, yang juga berfungsi dalam memposisikan identitas budaya, bagi masyarakat tertentu sebagai pencirinya, pada akhirnya harus menjadi spirit yang tidak boleh diabaikan dalam konteks menjaga nilai-nilai kebangsaan agar tidak pudar dan agar nilai-nilai itu tetap dihayati dalam situasi apapun.

Sebagai bangsa yang bhineka, Indonesia memiliki dua macam sistem budaya yang keduanya harus dipelihara, dikembangkan, dan diberdayakan yakni sistem budaya nasional dan sistem budaya etnik lokal. Sistem budaya nasional adalah sesuatu yang hingga kini masih berproses terus. Sistem ini berlaku secara umum untuk seluruh bangsa Indonesia, tetapi sekaligus berada di luar ikatan budaya etnik lokal yang manapun. Nilai-nilai budaya yang terbentuk dalam sistem budaya nasional itu bersifat menyongsong masa depan.

Dalam hubungan ini, kenyataannya, nilai-nilai tersebut hakikatnya merupakan "serat-serat irisan" yang terbentuk tatkala dua atau lebih budaya etnik lokal bersemuka, bersinggungan, dan saling memperkaya atas dasar persamaan-persamaan yang ada di antaranya. Jadi, nilai-nilai budaya lokal tertentu menjadi bercitra translokal/nasional karena dipadu dengan nilai-nilai lain yang sesungguhnya diderivasikan dari nilai-nilai budaya lama yang terdapat dalam berbagai sistem budaya etnik lokal.

Kearifan lokal pada dasarnya dapat dipandang sebagai landasan bagi pembentukan jati diri bangsa secara translokal (nasional). Kearifan lokal itulah yang membuat budaya bangsa memiliki akar. Budaya etnik lokal seringkali berfungsi sebagai sumber atau acuan bagi penciptaan-penciptaan baru, misalnya dalam bahasa, seni, tata masyarakat, teknologi, dan sebagainya, yang kemudian ditampilkan dalam perikehidupan lintasbudaya. 
Karenanya, upaya penggalian kearifan lokal pada dasarnya untuk mencari, dan akhirnya untuk menetapkan identitas bangsa, yang mungkin hilang karena proses persilangan dialektis, atau karena akulturasi dan transformasi yang telah, sedang, dan akan terus terjadi sebagai sesuatu yang tak terelakkan. Upaya menemukan identitas bangsa yang baru atas dasar kearifan lokal merupakan hal yang penting demi penyatuan budaya bangsa di atas dasar identitas daerah-daerah Nusantara. Jadi, ujung akhir situasi sadar budaya yang ingin dicapai bukanlah situasi nekrofili, yakni perasaan cinta kepada segala sesuatu yang bendawi/wujudiyah yang tidak berjiwa kehidupan, melainkan situasi biofili, yakni perasaan cinta kepada segala sesuatu yang maknawiah yang berjiwa kehidupan. Dengan cara demikian, seluruh warga bangsa diharapkan memiliki kekenyalan budaya yang memadai dalam menghadapi tantangan global.

c) Budaya Barat yang sudah maju secara ekonomis dan teknologis secara tak terhindarkan telah melanda kita dengan begitu kuat sehingga kita merasa kehilangan (sebagian) identitas tradisional bangsa. Munculnya keinginan untuk membangun kembali identitas bangsa, pada hakikatnya dapat dipertimbangkan sebagai salah satu sarana yang penting untuk menyeleksi, dan bukannya melawan, pengaruh budaya "lain." Gerakan nativisme bisa saja dipandang naif, akan tetapi ia merupakan suatu reaksi logis apabila diletakkan dalam perspektif budaya yang berubah sangat cepat.

Dengan selalu memperhitungkan kearifan lokal lewat dan dalam proses budaya, keniscayaan masyarakat terperangkap dalam situasi menjadi masyarakat yang terasing dari realitas dirinya, yang "menjadi ada" dalam pengertian "menjadi seperti liyan dan bukannya dirinya sendiri," dapat dihindari. Jadi, penempatan hasil upaya penggalian kearifan-kearifan lokal dalam proses budaya harus selalu dimaknai dalam konteks upaya menyiapkan masyarakat memiliki kekenyalan budaya, dan bukannya sebagai domestikasi atau penjinakkan sosial budaya. Dikatakan demikian karena upaya menggali dan menyadari kembali kearifan lokal dapat dikatakan sebagai gerakan kembali pada basis nilai budaya daerahnya 
sendiri sebagai bagian upaya membangun identitas, dan sebagai semacam filter dalam menyeleksi pengaruh budaya liyan.

Nilai-nilai kearifan lokal tersebut meniscayakan fungsi yang strategis bagi pembentukan karakter dan identitas, yang pada gilirannya akan memunculkan sikap budaya yang mandiri, penuh inisiatif, dan kreatif. Perawatan, pengembangan, dan pemberdayaan kearifankearifan lokal yang relevan dan kontekstual memiliki arti penting bagi berkembangannya suatu masyarakat, terutama jika dilihat dari sudut kekenyalan budaya, di samping juga mempunyai arti penting bagi identitas daerah yang bersangkutan. Karya-karya seni budaya yang menempatkan nilai-nilai lokalnya sebagai sumber inspirasi kreatif, bagi daerah yang bersangkutan akan mendorong munculnya sikap bangga terhadap budaya dan daerahnya. Karya-karya kreatif itu bisa saja ditampilkan dalam wajah atau wacana translokal sehingga memiliki sumbangan yang besar bagi terciptanya identitas baru bagi bangsa secara keseluruhan. Kearifan lokal, yang juga meniscayakan adanya muatan budaya masa lalu, dengan demikian, juga berfungsi untuk membangun kerinduan pada kehidupan nenek moyang, yang menjadi tonggak kehidupan masa sekarang. Anggapan bahwa yang relevan dengan kehidupan hanyalah "masa kini dan di sini" juga dapat dihindari. Kearifan lokal dapat dijadikan semacam jembatan yang menghubungkan masa lalu dan masa sekarang, generasi nenek moyang dan generasi sekarang, demi menyiapkan masa depan dan generasi mendatang. Pada gilirannya, ia pun dapat dijadikan semacam simpai perekat budaya antargenerasi, dan menghindarkan diri dari situasi ahistoris.

Dalam konteks tersebut, pendidikan bahasa dan seni secara strategis menjadi penting. Pendekatan multikultural --yang menghindari sifat satu arah, kognitif, dan eksklusif; juga menghindari superioritas, primordialisme, dan eksklusivisme nilai tertentu-merupakan salah satu jalan yang bisa ditempuh. Melaluinya, pemahaman nilai-nilai bersama dan upaya kolaboratif mengatasi masalah-masalah bersama 
diupayakan, potensi nilai yang bersifat transdicahayakan. Nilai tenggang rasa antarsesama dijadikan dasar utama, di samping keserbanekaan keyakinan, tradisi, adat, dan serat-serat budaya lainnya ditempatkan sewajar-wajarnya melalui tegur-sapa yang ramah. Semua itu dapat terlaksana apabila materi dalam proses pendidikan bahasa dan seni diperhitungkan sebagai "rumah" pengalaman kemanusiaan kita.

Dalam dan melalui proses semacam itu, kita "merumahkan" pengalaman-pengalaman kita yang tidak pernah singular. Jika butir tersebut mampu kita implementasikan dalam rangka nation and character building, niscaya histeria sosial, situasi yang rentan terhadap sawan budaya, atau schizofrenia kultural, dapat dihindari. Pendidikan karakter niscaya menghindari terbentuknya manusia-manusia yang berwajah garang, yang wataknya dan perilakunya keras, brutal, dan agresif, yang salah satu kehendak besarnya adalah memusuhi yang lain, yang satu ingin menguasai dan menindas yang lain.

Pendidikan karakter niscaya berupaya membentuk manusia yang mampu menghargai harkat dan hak-hak azasi, dan bukannya membentuk manusia yang hanya menjadi pendusta bagi hati nurani diri mereka sendiri. Pengembangan pendidikan karakter berbasis kearifan lokal, dengan demikian, hakikatnya merupakan upaya menyiapkan dan membentuk sebuah masyarakat yang keberlangsungannya didasarkan pada prinsipprinsip moral. Untuk mewujudkannya, "angan-angan" segelintir manusia (yang kebetulan sedang "berkuasa," misalnya saja), tidak boleh mengalahkan konvensi, common sense, dan kesepakatan-kesepakatan yang sudah ada, apalagi yang sudah terwujud dalam kaidah hukum; pertumbuhan organisasi-organisasi kewargaan juga perlu disemai, bukan malah ditekan; perbedaan pendapat juga tidak boleh dibungkam. Dengan demikian, upaya pengembangan yang dilaksanakan sudah seharusnya mampu pula menemukan, menghidupkan, dan menyegarkan kembali semangat kebebasan, individualitas, kemanusiaan, dan toleransi dalam jiwa. Untuk itu, keutamaan kecendekiawanan dan pengayaan 
kultural merupakan keniscayaan, yaitu keniscayaan untuk menanamkan ke dalam dirinya prinsip-prinsip etika dan kebenaran moral yang berasal dari cita-cita peradaban dan warisan intelektual yang benar-benar berakar pada kultur sendiri.

d) Pengintegrasian nilai-nilai budaya dan kearifan lokal dalam proses pendidikan bahasa dan seni mengandaikan bahwa siswa/mahasiswa akan mengkonstruksikan pengetahuan atau menyemaikan benih-benih nilai positif dalam dirinya sebagai hasil "pemikiran" dan interaksinya dalam konteks sosial-budaya yang mengepung dan mengkondisikannya. Siswa/mahasiswa diharapkan mampu menciptakan makna yang saheh bagi dirinya berdasarkan interaksi antara pengetahuan yang telah dimiliki, diketahui, dan dipercayai; dengan gejala, gagasan, atau informasi baru yang diperoleh di dalam proses pendidikan yang ditempuhnya. Oleh karena itu, nilai-nilai budaya dan kearifan lokal yang dimaksud harus dihadirkan dalam kelas pembelajaran/perkuliahan.

Penempatan nilai-nilai kearifan lokal sebagai konteks pendidikan bahasa dan seni berpotensi mendekatkan dan menyadarkan peserta-didik terhadap lingkungan kehidupannya: dari adat istiadat dan bendabenda budaya tempat nilai-nilai itu melekat dan bersemayam di dalamnya. Dengan demikian, strategi penghadiran lingkungan budaya merupakan bagian dari proses penebaran benih dan pembumian nilai. Ketika siswa/mahasiswa berinteraksi dan beradaptasi dengan lingkungan (budaya), sesungguhnya mereka sedang berada dalam periswa belajar. Lingkungan budaya merupakan sebuah "lokus" untuk mendapatkan pengalaman (-pengalaman baru). Kearifan lokal yang diintegrasikan dalam praksis pendidikan bahasa dan seni akan menciptakan medan eksplorasi bagi siswa/mahasiswa dalam memahami dan menghayati nilai tertentu. Mereka tidak hanya ngerti, tetapi juga nglakoni dan ngrasakke, berinteraksi dengannya melalui beragam proses: knowing, doing, dan being pun terintegrasi.

Ketika hasil penggalian dan pengembangan nilainilai budaya dan kearifan lokal ditautkan dengan, dan diintegrasikan dalam pendidikan bahasa dan seni, 
terdapat tiga alternatif yang dimungkinkan. Pertama, pendidikan tentang nilai-nilai budaya dan kearifan lokal tertentu. Alternatif ini menempatkan nilai-nilai budaya dan kearifan lokal sebagai subjek dan objek kajian. Nilainilai budaya dan kearifan lokal tertentu dipelajari dalam satu program studi khusus: tentang budaya dan untuk budaya. Dalam hal ini, nilai-nilai budaya dan kearifan lokal tidak terintegrasi dengan disiplin keilmuan lain. Kedua, pendidikan dengan nilai-nilai budaya dan kearifan lokal terjadi pada saat nilai-nilai budaya dan kearifan lokal tertentu diperkenalkan kepada siswa/mahasiswa sebagai cara atau metode untuk mempelajari suatu konsep tertentu. Belajar dengan nilai-nilai budaya dan kearifan lokal meliputi pemanfaatan beragam hal yang inheren di dalamnya: menjadi media pembelajaran dalam proses belajar, menjadi konteks dari contoh-contoh tentang konsep atau prinsip, serta menjadi konteks penerapan prinsip atau prosedur tertentu. Ketiga, pendidikan melalui nilai-nilai budaya dan kearifan lokal merupakan strategi yang memberikan kesempatan kepada siswa/mahasiswa untuk menunjukkan pencapaian pemahaman atau makna yang diciptakannya melalui beragam perwujudan budaya yang berbasis nilai-nilai budaya dan kearifan lokal tertentu. "Produk-produk" budaya yang diwujudkan siswa/mahasiswa, misalnya saja poster, karangan, lukisan, lagu, ataupun puisi yang bertema nilai-nilai budaya dan kearifan lokal tertentu, dapat diperhitungkan untuk melihat seberapa jauh peserta-didik memperoleh pemahaman proses tertentu, dan seberapa besar kreativitasnya dalam rangka pencapaian kompetensi tertentu.

e) Akhirnya, ketika etnisitas dipahami sebagai sebuah konsep kultural yang berpusat pada pembagian normanorma, nilai-nilai, kepercayaan, simbol, dan praktikpraktik kultural, maka kearifan lokal sesungguhnya menjadi sarana yang utama dalam mengikat keutuhan etinisitas itu. Oleh karena itu, ketika kearifan lokal diintegrasikan dalam praksis pendidikan bahasa dan seni, model-model pembelajaran yang dipilih dan dikembangkan perlu dilakukan secara cermat. Dalam hubungan ini, paling tidak terdapat 6 (enam) model yang 
perlu dicermati, yakni model pohon, model kristal, model sangkar burung, model jamur, model amuba, dan model DNA.

Dalam "model pohon," akar proses pengembangan yang dilakukan berada dalam nilai-nilai lokal dan tradisi, tetapi menyerap sumber-sumber eksternal yang relevan dan berguna untuk tumbuh keluar. Dalam kaitan ini, pengembangan pembelajaran kearifan lokal dalam konstelasi pendidikan translokal (nasional) dan global tetap mengedepankan, karena memerlukan, akar-akar budaya lokal. Tujuan utamanya adalah menyiapkan pribadi lokal yang berwawasan internasional, yakni individu yang utamanya bertindak pada tataran lokal, tetap ia/mereka berkembang secara global.

Dengan demikian, pengembangan kurikulum pembelajaran kearifan lokal harus didasarkan pada nilainilai dan aset budaya lokal itu sendiri, tetapi sekaligus menyerap teknologi dan wawasan global yang cocok untuk mendukung pengembangan komunitas berikut individu-individunya sebagai warga lokal. Model ini diharapkan mampu mendorong komunitas lokal untuk memelihara nilai-nilai tradisional, identitas kultural, dan akumulasi pengetahuan lokalnya karena tumbuh, berkembang, dan berinteraksi dengan asupan energi dari sumber-sumber eksternal. Pertumbuhan komunitas lokal yang berhasil akan memberikan kontribusi pada pertumbuhan komunitas dan pengetahuan global.

Akan tetapi, jika akar kulturalnya sempit dan miskin, pertumbuhan komunitas dan individu lokal akan menjadi begitu terikat dan menyakitkan. Untuk menghindari hal itu, juga untuk menghindari jebakan pertumbuhan dan perkembangan yang hanya bersifat teknis jangka pendek, dinamisasi kultural harus dilakukan juga secara berbarengan. Dengan cara demikian, pengetahuan global yang dikonversikan ke dalam pengetahuan lokal tidak terbatas pada bias kultural, yang seringkali berkedok sikap "selektif."

Kunci proses pengembangan "model kristal" terletak pada kesadaran bahwa pemekaran kearifan lokal berfungsi untuk mengkristalisasikan dan mengakumulasi pengetahuan eksternal (translokal dan global) yang cocok 
dengan bentuk-bentuk yang sudah ada. Dalam kaitan ini, pengembangan lebih diarahkan untuk mengakumulasi pengetahuan eksternal yang ada di sekitar yang lokal.

Implikasinya, desain kurikulum dan pembelajaran diorientasikan untuk mengidentifikasi kebutuhan dan nilai-nilai kelokalan yang paling mendasar sebagai landasan fundamental untuk mengakumulasi sumbersumber pengetahuan eksternal yang relevan dan signifikan bagi pendidikan sebagai proses pembudayaan. Yang pertama dan utama adalah pemahaman terhadap struktur pengetahuan kelokalan sebagai dasar ketika pengetahuan dan kearifan yang bersifat eksternal diakumulasi. Model ini diharapkan mampu menyiapkan manusia lokal yang memiliki sejumlah pengetahuan global, yakni pribadi-pribadi yang mampu berpikir dan bertindak lokal dengan memunculkan teknik-teknik global. Dalam model ini, konflik antara kebutuhan lokal dan pengetahuan global yang diserap dan diakumulasi dalam pengembangan komunitas dan individu lokal, dapat diminimalkan.

Karena, asupan global hal-hal yang dikehendaki dan yang tidak dikehendaki lebih mudah untuk diidentifikasi. Eksternalisasi yang berlebihan juga lebih mudah dikendalikan. Hanya saja, tidak mudah untuk mendapat seperangkat nilai atau hasil-hasil lokal yang baik yang dapat digunakan untuk mengkristalisasikan dan melokalisasikan pengetahuan dan kearifan lokal yang berdaya guna dan membuahkan hasil secara penuh. Tipetipe dan hakikat yang asli lokal itu sendiri bisa saja hanya mengkristalkan hal-hal sama saja dengan yang sudah ada.।

Proses pengembangan "model sangkar burung" terbuka bagi kehadiran sumber-sumber dan pengetahuan global, tetapi membatasi perkembangan lokal dan interaksi yang bersifat eksternal untuk menetapkan suatu kerangka kerja. Pengembangan pembelajaran kearifan lokal sebagai bagian dari budaya lokal dalam keseluruhannya dalam konstelasi yang lebih luas memerlukan kerangka kerja lokal yang berfungsi protektif dan selektif. Dalam kaitan ini, desain kurikulum hendaknya memiliki kerangka kerja lokal 
dengan batas-batas ideologis dan norma-norma sosial yang jelas. Harapannya, semua aktivitas edukasional memiliki fokus lokal yang jelas ketika bersemuka dengan pengetahuan dan masukan global. Perhatian dan kesetiaan lokal hendaknya menjadi bagian utama pendidikan.

Model ini diharapkan mampu menyiapkan manusia lokal dengan wawasan global yang terbatasi, yakni pribadi- yang bertindak lokal dengan pengetahuan global yang sudah disaring. Kerangka kerja yang disiapkan diharapkan mampu menjamin relevansi lokal, membantu menghindari hilangnya identitas lokal, dan memproteksi interes lokal dari globalisasi yang berlebihan. Hanya saja, penetapan batas sosial dan kultural yang tepat untuk menyaring dampak global dan untuk menjamin relevansi lokal bukan hal yang mudah dilakukan. Karena, batas tersebut bisa saja terlampau ketat dan tertutup, sehingga interaksi penting dengan dunia luar menjadi terkendala, di samping pertumbuhan pengetahuan lokal juga cenderung terhambat.

Dalam prosesnya, "model DNA" mengidentifikasi dan mencangkok elemen-elemen kunci yang lebih baik yang berasal dari pengetahuan global untuk menggantikan komponen-komponen lokal yang sudah tidak lagi berdaya dalam rangka pengembangan. Implikasinya, desain kurikulum hendaknya sangat selektif, baik terhadap pengetahuan lokal maupun global.Tujuannya untuk memilih elemen-elemen yang terbaik dari keduanya. Pemahaman terhadap kelemahan dan kekuatan elemen, baik pengetahun lokal maupun global, merupakan hal yang penting dalam rangka menumbuhkan sikap terbuka bagi pencangkokan elemenelemen apapun yang baik dalam konteks lokal.

Cara ini diharapkan mampu menyiapkan manusia dengan elemen campuran antara yang lokal dan global, yakni pribadi-pribadi yang mampu bertindak dan berpikir dengan pengetahuan campuran lokal dan global. Dalam model ini, investigasi rasional dan transplantasi elemen dan pengetahuan yang valid terbuka lebar hampir tanpa kendala lokal dan kultural. Dalam rangka mempelajari dan memperbaiki perkembangan dan pratik-praktik lokal, 
model ini lebih efisien. Akan tetapi, identifikasi terhadap kelemahan dan kekuatan elemen-elemen tertentu belum tentu benar, baik secara kultural maupun sosial.

Di samping itu, asumsi yang menyatakan pencangkokan dan penggantian dapat dilakukan dengan mudah tanpa resistensi kultural dan tanpa dampak sosial yang negatif terhadap perkembangan individu dan komunitas lokal, merupakan asumsi yang terlampau mekanistik. Yang diutamakan dalam "model jamur" adalah proses pencernaan tipe-tipe pengetahuan global sebagai nutrisi bagi individu dan perkembangan lokal.

Artinya, pengetahuan lokal berfungsi untuk mencerna sejumlah pengetahuan global dan mengkonversikannya menjadi nutrisi lokal demi pengembangan individu dan komunitas lokal. Implikasinya, kurikulum dan pembelajaran diarahkan pada kemampuan mengidentifikasi dan mempelajari apakah pengetahuan global itu bernilai dan penting. Aktivitas pendidikan didesain untuk mencerna pengetahuan global yang kompleks ke dalam bentukbentuk yang tepat sehinggai dapat disuap oleh individuindividu lokal demi pertumbuhan yang diperlukan.

Model ini diharapkan mampu menyiapkan manusia yang dilengkapi dengan tipe pengetahuan global tertentu, yakni pribadi-pribadi yang dalam hal bertindak dan berpikir bergantung pada pengetahuan global yang relevan. Dalam model ini, pencernaan dan penyerapan elemen-elemen pengetahuan global yang berguna lebih mudah disiapkan daripada menghasilkan pengetahuan lokal dari awal. Akar demi pertumbuhan dan pengembangan didasarkan pada pengetahuan global sebagai alternatif nilai-nilai atau budaya lokal. Akan tetapi, model ini mengutamakan proses pencernaan dan penyerapan satu-arah terhadap pengetahuan eksternal.

Dalam prosesnya, "model amuba" membuat pengetahuan global benar-benar berguna dengan hambatan lokal yang paling minimal. Artinya, pengetahuan lokal difungsikan untuk mendayagunakan dan mengakumulasi secara maksimal pengetahuan global dalam konteks lokal. Implikasinya, kurikulum hendaknya memasukkan rentangan pengetahuan dan perspektif 
global secara penuh. Hambatan kultural dan nilai-nilai lokal dapat diminimalkan dalam desain kurikulum dan pembelajaran agar sikap terbuka secara total terhadap pembelajaran global dapat ditumbuhkan. Model ini diharapkan mampu menyiapkan manusia yang terbuka dan flkesibel tanpa identitas lokal apapun, yakni bertindak dan berpikir global dan cair. Kekuatan model ini terletak pada keterbukaan dan fleksibilitasnya terhadap seluruh eksposur global.

Dalam mengakumulasi sumber-sumber dan pengetahuan global, hambatan lokal dan kultural sedikit, sehingga perkembangan individu dan komunitas lokal memiliki kesempatan menguntungkan yang lebih luas. Akan tetapi, model ini berpotensi menghilangkan nilainilai lokal dan identitas kultural. Sangat dimungkinkan komunitas lokal akan kehilangan panduan dan solidaritas sosial sepanjang proses globaliasasi.

f) Keenam model pengembangan yang dikemukakan di atas dapat dijadikan alternatif pengembangan pembelajaran kearifan lokal. Pilihan terhadapnya lebih ditentukan arah orientasi pembelajaran kearifan lokal sebagai bagian penting budaya lokal dalam keseluruhannya.

Berdasarkan luasnya dependensi pengetahuan global dan orientasi nilai dan kultur lokal, tampak bahwa model amuba dan jamur kurang relevan dan kurang signifikan karena dependensi globalnya sangat kuat. Model pohon, kristal, dan sangkar burung memiliki orientasi lokal lebih kuat, sedangkan model DNA terletak di antara dua kelompok tersebut. Dengan demikian, terdapat dua orientasi utama. Pertama, orientasi pengembangan pembelajaran kearifan lokal bisa saja secara total menolak pengetahuan dan keterlibatan global, tetapi secara kuat menekankan relevansi dan keterlibatan komunitas lokal dalam merancang dan melaksanakan pendidikan.

Nilai-nilai lokal yang ada, identitas kultural, pegalaman komunitas, dan pengetahuan lokal merupakan bagian-bagian inti pendidikan. Kedua, orientasinya adalah pendidikan yang terikat oleh tempat secara tradisional, yang diisolasikan dari komunitas lokal dan jagat luar. Tujuan pendidikan, isi kurikulum, dan praktik pedagogis 
dipelihara agar tidak berubah untuk kurun waktu yang lama dan sangat kecil relevansinya dengan pengalaman komunitas keseharian. Terdapat kesenjangan besar antara pendidikan yang diberikan dengan realitas global dan lokalDua titik ekstrem tersebut niscaya tidak menguntungkan ketika pembelajaran kearifan lokal diperhitungkan sebagai komponen strategis kebudayaan dalam fungsi ideologis, pedagogis, dan kulturalnya.

Perkembangan individu dan komunitas lokal sering kehilangan tradisionalitasnya ini pada saat berhadapan dengan tantangan serius dalam era baru transformasi dan globalisasi. Oleh karena itu, ke depan, pengembangan hendaknya diorientasikan pelokalan dan pengglobalan sekaligus. Ini merupakan skenario yang ideal, yang menekankan baik lokalisasi mapun globalisasi dalam pendidikan bahasa dan seni. Pengintegrasian keduanya dapat dilakukan melalui model pohon, kristal, sangkar burung, dan DNA. Skenario ini bertujuan melokalkan pengetahuan dan sumber-sumber global dan membuatnya valid dan relevan dengan konteks lokal.

Di samping itu juga bertujuan untuk mengglobalkan kesempatan dan pengalaman edukasional bagi para siswa dan meluaskan wawasan internasional mereka. Apabila orientasi pengembangan pembelajaran kearifan lokal diarahkan pada lokalisasi dan globalisasi sekaligus, konsepsi belajar dan pembelajaran tentang, melalui, dan dengan kearifan lokal menjadi penting untuk dipertimbangkan dalam praktik pelaksanaannya.

Proses pembelajaran yang cenderung menekankan pencapaian kurikulum dan penyampaian materi secara tekstual semata harus segera ditinggalkan dan diganti dengan pengembangan kemampuan belajar, kreativitas, dan logika berpikir siswa. Situasi dan posisi siswa/mahasiswa sebagai penerima pasif semua informasi yang disampaikan guru/dosen, juga harus segera didinamisasikan sehingga dominasi guru/dosen, ketergantungan pada pada buku teks, dan kebenaran tunggal dalam proses pembelajaran sedikit demi sedikit dapat ditinggalkan. Dalam kaitan ini, pembelajaran bermakna harus diciptakan dan dirancang secara kreatif, sehingga memungkinkan terjadi interaksi dan negosiasi 
untuk penciptaan arti dan konstruksi makna dalam diri setiap siswa/mahasiswa dan guru/dosen, termasuk pemanfaatan kearifan lokal sebagai budaya lokal dalam pembelajaran. Hal ini penting untuk diperhitungkan karena secara konstruktivistik, siswa mengkonstruksikan pengetahuan atau menciptakan makna sebagai hasil dari pemikiran dan interaksinya dalam suatu konteks sosial. Bukankah setiap individu menciptakan makna dan pengertian baru, berdasarkan interaksi antara apa yang telah dimiliki, diketahui, dan dipercayai, dengan fenomena, ide, atau informasi baru yang dipelajari.

Karena kearifan lokal juga merupakan "rumah pengalaman kemanusiaan," keterlibatan dan "persinggahan" siswa/mahasiswa dengannya dalam pembelajaran memungkinkan mereka belajar lebih banyak dari apa yang seharusnya. Dengan cara demikian, siswa/mahasiswa pun belajar tentang budaya komunitasnya - termasuk miskonsepsi yang inheren dalam budaya tersebut. Persentuhan siswa/mahasiswa dengan beragam bentuk budaya dalam proses pembelajaran sekaligus berarti terbukanya ruang dan peluang bagi mereka untuk secara bebas menggali prinsip-prinsip "keilmuan" berdasarkan konteks yang sudah dikenalnya, menemukan hal-hal yang bermakna di sekelilingnya (dalam komunitas budayanya), dan mendorongnya untuk membuka dan menemukan hal-hal yang baru. Pada akhirnya, mereka pun diharapkan mampu menjadi pribadi-pribadi yang berkarakter, yang memiliki kedaultan penuh atas dirinya. 


\section{BAB 6 KEARIFAN LOKAL DAN TANTANGAN ZAMAN}

Kearifan lokal merupakan suatu bentuk warisan budaya Indonesia yang telah berkembang sejak lama. Kearifan lokal lahir dari pemikiran dan nilai yang diyakini suatu masyarakat terhadap alam dan lingkungannya. Di dalam kearifan lokal terkandung nilai-nilai, norma-norma, sistem kepercayaan, dan ide-ide masyarakat setempat. Oleh karena itu kearifan lokal di setiap daerah berbeda-beda. Kearifan lokal berkaitan erat dengan pengelolaan sumberdaya alam dan lingkungan. Masyarakat memiliki sudut pandAang tersendiri terhadap alam dan lingkungannya. Masyarakat mengembangkan cara-cara tersendiri untuk memelihara keseimbangan alam dan lingkungannya guna memenuhi kebutuhan hidupnya. Pengelolaan sumberdaya alam dan lingkungan melalui pengembangan kearifan lokal memiliki kelebihan tersendiri. Selain untuk memelihara keseimbangan sumberdaya alam dan lingkungannya, kebudayaan masyarakat setempat pun dapat dilestarikan.

Kearifan lokal memiliki banyak fungsi sebagaimana yang diungkapkan oleh Sirtha (2003) sebagaimana dikutip oleh Sartini (2004) sebagaimana dikutip oleh Aulia (2010), menjelaskan bahwa bentuk-bentuk kearifan lokal yang ada dalam masyarakat dapat berupa: nilai, norma, kepercayaan, dan aturan-aturan khusus.

Bentuk yang bermacam-macam ini mengakibatkan fungsi kearifan lokal menjadi bermacam-macam pula. Fungsi tersebut antara lain adalah:

a. Kearifan lokal berfungsi untuk konservasi dan pelestarian sumberdaya alam.

b. Kearifan lokal berfungsi untuk mengembangkan sumber daya manusia.

c. Berfungsi sebagai pengembangan kebudayaan dan ilmu pengetahuan.

d. Berfungsi sebagai petuah, kepercayaan, sastra, dan pantangan.

Namun, dewasa ini kearifan lokal menghadapi tantangantantangan yang mengancam keberadaan dan kelestariannya. Kearifan lokal yang telah terbentuk sejak lama kini mulai terkikis seiring berkembangnya teknologi diikuti meningkatnya proses 
adopsi inovasi serta difusi adopsi teknologi. Suhartini (2009) menyatakan bahwa kearifan lokal-kearifan lokal ikut berperan dalam pengelolaan sumberdaya alam dan lingkungannya. Namun demikian kearifan lokal juga tidak lepas dari berbagai tantangan seperti: bertambahnya terus jumlah penduduk, teknologi modern dan budaya, modal besar serta kemiskinan dan kesenjangan.

Berbagai teknologi yang berkembang saat ini pada dasarnya memiliki potensi besar untuk merusak keseimbangan alam dan lingkungan. Berbagai bentuk eksploitasi terhadap alam kini sudah merupakan hal yang dianggap biasa. Begitu banyak elemen masyarakat hingga pemerintah mengadopsi berbagai teknologi untuk mengekploitasi alam secara besar-besaran, tanpa pernah memperhatikan aspek kearifan lokal yang berkembang di masyarakat. Salah satu contoh adalah penggunaan teknologi penangkapan ikan di Maluku yang tidak memperhatikan kearifan lokal masayarakat. Dampak yang ditimbulkan adalah rusaknya sumberdaya air dan tersingkirkannya kearifan lokal masyarakat Maluku yang disebut sasih ${ }^{1}$. Sehingga pada akhirnya secara perlahan-lahan kearifan-kearifan lokal tersebut memudar bahkan menghilang di tengah-tengah kehidupan masyarakat. Selain itu juga berakibat kepada terjadinya ketidakseimbangan lingkungan yang dapat mengakibatkan terjadinya berbagai bencana alam. Masuknya berbagai teknologi tersebut menyingkirkan peran kearifan lokal dalam mengelola sumberdaya alam dan lingkungan adalah norma-norma yang didasarkan pengetahuan lokal yang mengatur waktu pemanenan ikan.

Masayarakat memiliki pengetahuan pada bulan-bulan kapan ikan bertelur. Masyarakat mulai meninggalkan pola pikir holistik ${ }^{2}$ dan beralih kepada pola pikir mekanistik ${ }^{3}$ serta berorientasi komersil. Sehingga melahirkan perilaku-perilaku yang ingin menaklukan alam untuk memenuhi kepentingan pribadi atau kepentingan kelompok. Sehingga pada akhirnya banyak terjadi berbagai bencana alam akibat keseimbangan alam diganggu.

Selain perkembangan teknologi, tantangan-tantangan lain yang dihadapi kearifan lokal-kearifan lokal masyarakat adalah pertambahan penduduk. Robert Malthus dalam Suhartini menyatakan bahwa penduduk yang banyak merupakan penyebab kemiskinan, hal ini terjadi karena laju pertumbuhan penduduk yang mengikuti deret ukur tidak akan pernah terkejar oleh pertambahan makanan dan pakaian yang hanya mengikuti deret hitung (Soerjani dkk, 1997:99). Adanya kebutuhan pangan yang 
tinggi menuntut orang untuk meningkatkan produksinya guna mencukupi kebutuhan tersebut, sehingga melakukan modernisasi pertanian dengan melakukan revolusi hijau. Dalam Revolusi hijau dikembangkan penggunaan bibit unggul, pemupukan kimia, pengendalian hama penyakit dengan obat-obatan, pembangunan saluran irigasi secara besar-besaran untuk pengairan dan penggunaan teknologi pertanian dengan traktor untuk mempercepat pekerjaan. Sebagai akibat pelaksanaan revolusi hijau yang menekankan pada tanaman padi secara monokultur dengan bibit unggul maka akan mempengaruhi kehidupan petani lokal dalam menggunakan bibit lokal yang sebenarnya mempunyai ketahanan terhadap hama dan penyakit, pupuk kandang dan pupuk organik yang digantikan dengan pupuk kimia, penggunaan hewan untuk membajak yang digantikan traktor, penggunaan obat-obatan dari tanaman untuk pertanian dengan obat-obatan kimia. Berikut dipaparkan salah satu contoh persentase penggunaan berbagai pupuk di daerah Temanggu. Tabel berikut menunjukkan bahwa semakin meningkatnya ketergantungan petani terhadap penggunaan pupuk kimia dibandingkan penggunaan pupuk organik.

Menghadapi tantangan-tantangan tersebut, prospek kearifan lokal di masa depan bergantung dari pemanfaatan dan pemberdayaan kearifan lokal yang dimiliki masyarakat guna mengelola sumberdaya alam dan lingkungan. Pengetahuan mengenai kearifan lokal yang dimiliki masyarakat yang diturunkan secara turun temurun serta inovasi dan teknologi juga mempengaruhi keberlangsungan kearifan lokal di masa depan. Pemerintah sebagai pemegang kekuasaan sudah saatnya memberlakukan kebijakan terkait adopsi teknologi penggunaannya serta difusi teknologi yang melindungi sumberdaya alam dan lingkungan melalui kearifan lokal. Berbagai kearifan lokal yang masih bertahan adalah pranoto mongso ${ }^{4}$ di Jawa dan nyabuk gunung 5 .

Sartini mengungkapkan bahwa ada banyak peluang untuk pengembangan wacana kearifan lokal Nusantara. Di samping itu kearifan lokal dapat didekati dari nila-inilai yang berkembang di dalamnya seperti nilai religius, nilai etis, estetis, intelektual atau bahkan nilai lain seperti ekonomi, teknologi dan lainnya. Maka kekayaan kearifan lokal menjadi lahan yang cukup subur untuk digali, diwacanakan dan dianalisis mengingat faktor perkembangan budaya terjadi dengan begitu pesatnya. 


\section{A. Berfikir Global Bertindak Lokal}

KENYATAAN globalisasi yang dikatakan menembus batas ruang dan waktu menjadikan tema lokalitas hangat diperbincangkan. Sebuah upaya dalam kesadaran berbagsa dan bernegara dimana warganya sudah, saya rasa dan mungkin Anda rasakan, frustasi dengan penggerak roda pemerintahan pusat. Wacana yang digulirkan dari berbagai forum diskusi, seminar, ataupun kuliah hanya satu: Perlawanan. Paradigma yang dibangun juga selalu sama, daya saing sebuah negara bangsa dalam kancah dunia internasional. Industri massif untuk keperluan global kini mulai dipertanyakan. Muncullah kemudian slogan-slogan hingga gerakan legal dan non-legal berdiri atas nama menjunjung tinggi nilai lokalitas. Ranah teknisi praktis bukan dikolaborasikan, namun, justru dibenturkan dengan datadata sejarah. Sebuah niatan luhur.

Kebangkitan gerakan lokal selalu memiliki tiga senjata, yaitu tradisi, seni, dan makanan. Selain dari itu seringkali masih sulit untuk diterima. Gerakan tersebut mengambil hati masyarakat luas dengan sebuah harapan akan kesejahteraan, lagi-lagi menyentuh dimensi ekonomis. Terkhusus untuk orang-orang yang memiliki latar belakang Jawa, pengarsipan mengenai wilayah yang mereka tempati ini tersedia dengan sangat banyak. Alhasil, acuan yang mereka gunakan dengan mudah dicari dan tidak perlu sulit riset ataupun analisis yang memakan waktu lama. Majapahit menjadi tonggak terpenting sejarah kejayaan kelompok lokal atas pendudukan wilayah lain yang disebut Nusantara. Gerakan bernafaskan lokal ini selalu memilih jalan untuk kemudian 'menduniakan' unsur-unsur lokal mereka. Berbeda dengan industri skala besar, mereka tetap membangun pola yang terpusat. Ini merupakan sebuah strategi defensif secara spasial yang mencakup berbagai macam sumber daya yang ada didalamnya. Kemudian yang mereka junjung tinggi hanya berada pada satu kata, keaslian. Gerakan ini dibuat seolah menjadi kesadaran komunal. Namun saya katakan ini merupakan fiktif belaka.

Gerakan untuk membangkitkan unsur lokalitas tidak dibangun atas dasar kesadaran komunal untuk menjadi sebuah wilayah yang berdikari. Pendirian gerakan-gerakan yang bersifat lokal selalu rawan ditunggangi berbagai kepentingan privatisasi. Isu pemberdayaan masyarakat dengan mengembangkan tradisi, 
seni, dan makanan sebagai pemicu ekonomi kreatif, tidaklah kemudian menjadi sebuah perlawanan yang utuh. Pada saatnya, ketika senjata-senjata ini ampuh untuk memicu perekonomian masyarakat, saat itu pula hukum alam kapitalisme bermain. Hanya ada dua kemungkinan yang terjadi selanjutnya. Pertama, terjadinya pemiskinan secara komunal; dan kedua, terjadi jurang kesenjangan yang begitu besar. Dalam gerakan-gerakan bernafaskan kebangkitan unsur lokal, mereka menempatkan pasar sebagai salah satu tujuan utama selain penguatan identitas. Gerakan lokal yang pendiriannya dikatakan sebagai kesadaran komunal hanya mengantarkan kepada bentuk privatisasi lain.

\section{"Defensif lalu ofensif"}

Gerakan bernafaskan lokalitas, selalu memiliki sebuah strategi yang mereka sebut sebagai strategi budaya. Mereka menolak untuk menyamakannya sebagai strategi politik. Dasar dari argumen tersebut berasal dari satu kalimat. Kekecewaan dan keputusasaan terhadap negara. Dalih ini selalu muncul untuk 'memurnikan' setiap gerak-gerik mereka dan mengatasnamakan kesadaran komunal dari orang-orang yang peduli dengan budaya lokal. Legalitas mereka dapatkan dari gerakan sejenis yang ada di kancah nasional, seperti kementrian lalu turun ke dewan kesenian dan juga dinas pariwisata serta kebudayaan, provinsi lalu kaderisasi hingga tingkat desa. Paradigma yang dibangun tidak lagi diharuskan untuk bangga jika kemudian mereka 'ditanggap' oleh para pejabat. Mereka diberikan dikotomi untuk langsung menyasar tingkat global. Afiliasi yang paling dekat dengan gerakan ini adalah sebagai bagian dari promosi wisata. Celah mereka dapatkan dari wisata tidak kemudian menjadikan gerakan mereka hanya sebagai sebuah distributor barang siap pakai yang diambil dari etalase toko oleh pembeli.

Ketakutan nyata dari gerakan ini adalah hilangnya bentukbentuk dari lokalitas itu sendiri. Nilai yang kemudian terkandung didalamnya hanyalah sebagai 'tempelan', agar setidaknya ada pelajaran hidup yang didapatkan selain nilai ekonomis semata. Tidak berarti saya melihat tidak ada niatan baik untuk kemudian mengubah paradigma pembagian wilayah adidaya di dunia. Ketika sebuah perlawanan dengan senjata-senjata ini dikeluarkan, saya rasa pasar bukanlah tujuan yang sebenarnya. Memang pada dasarnya gerakan bernafaskan lokalitas ini memiliki niatan untuk melestarikan budaya dan juga menolak bentuk-bentuk penyergaman atas globalisasi. Sayangnya, 
gerakan-gerakan semacam ini seringkali mengkerdilkan perbedaan-perbedaan. Pada satu kesempatan, dalam satu forum diskusi menghajar habis-habisan tayangan MAHABARATA yang akhir-akhirnya sangat digandrungi. Kemudian segala yang menjadi catatan sejarah mereka kuatkan dengan perbandingan yang seringkali sangat tidak berbanding. Dan masih banyak lagi.

\section{"Pertaruhan identitas"}

Pernah dalam sejarah Indonesia, nilai-nilai lokal sangat dipersempit ruang geraknya. Pemerintah meneriakkan nasionalisme dengan praktik-praktik penguasaan di berbagai wilayah. Semboyan Bhineka Tunggal Ika adalah mantra sakti bagi pemerintah saat itu. Sampai hari ini semboyan itu tetap menjadi mantra sakti, namun bertransfromasi. Identitas nasional bukan lagi dibentuk dan dibangun oleh pemerintah. Hari ini kesadaran berbangsa tumbuh dari pojok-pojok negeri ini.

Gerakan bernafaskan lokalitas degan gagah menyatakan identitas lokal mereka yang kemudian dibawah naungan semboyan Bhineka Tunggal Ika. Semangat untuk meningkatkan kesejahteraan bukan hanya untuk masyarakat di wilayah tersebut, namun juga diharapkan sebagai pemicu bagi daerahdaerah lainnya untuk melakukan gerakan yang sama. Namun, kembali lagi, faktor kesejarahan yang kemudian mendominasi bangsa ini untuk saya menjadi sebuah kerisauan tersendiri. Bagaimana mungkin, ketika sebuah wilayah di NTT membuat gerakan yang sama dengan landasan sekuat di Jawa Timur. Ketimpangan terjadi. Ada yang menjadikan gerakan-gerakan ini tidak kemudian mengambil faktor sejarah atas dominasi, yaitu pasar. Ini menjadi sebuah ajang pertaruhan dari kebangkitan gerakan-gerakan lokal yang kemudian menyasar pada persaingan. Pada saat itulah kecerdikan dari aktor-aktor yang mengerti sekali bahwa manusia adalah homo economicus bermain.

Ketimpangan ini akan menjadikan masyarakat di sebuah wilayah tidak ingin dipersamakan dengan masyarakat di wilayah lainnya. Pertarungan wacana dari setiap gerakan lokal akan menjadikan identitas sebagai dalih pemersatu dan pada saatnya menjadi terbelah-belah. Bagi saya, ini merupakan cerminan bahwa negara ini sedang berada pada titik kegoyahan. Gerakan ini bukan hanya merujuk pada kerinduan warga negara untuk terlahir dengan identitas kultural. Lebih dari itu, gerakan ini merangsek masuk pada nalar masyarakat bahwa negara hanya sebagai boneka dan alat penindas bagi warganya. 


\section{BAB 7 \\ KEARIFAN LOKAL DI INDONESIA}

\section{A. Definisi Kearifan Lokal}

Menelisik pengertian kearifan lokal, hal pertama yang perlu dilakukan adalah melihat pengertian kamus tentang istilah itu. Dalam pengertian kamus, kearifan lokal (local wisdom) terdiri dari dua kata: kearifan (wisdom) dan lokal (local). Dalam Kamus Inggris Indonesia John M. Echols dan Hassan Shadily, local berarti setempat, sedangkan wisdom (kearifan) sama dengan kebijaksanaan. Kearifan lokal secara sederhana dapat diartikan sebagai kebijaksanaan lokal.

Secara filosofis, kearifan lokal dapat diartikan sebagai sistem pengetahuan masyarakat lokal/pribumi (indigenous knowledge systems) yang bersifat empirik dan pragmatis. Bersifat empirik karena hasil olahan masyarakat secara lokal berangkat dari faktafakta yang terjadi di sekeliling kehidupan mereka. Bertujuan pragmatis karena seluruh konsep yang terbangun sebagai hasil olah pikir dalam sistem pengetahuan itu bertujuan untuk pemecahan masalah sehari-hari (daily problem solving).

Dalam pengertian yang lebih luas, kearifan lokal dapat dipahami sebagai berikut: "Local wisdom is the knowledge that discovered or acquired by local people through the accumulation of experiences in trials and integrated with the understanding of surrounding nature and culture" (Naritoom, --)

Naritoom mengartikan kearifan lokal sebagai pengetahuan yang terakumulasi karena pengalaman-pengalaman hidup, dipelajari dari berbagai situasi di sekeliling kehidupan manusia dalam suatu wilayah. Hal serupa dapat dilihat pada definisi yang dimunculkan dalam situs Wikipedia.com:'Traditional knowledge, indigenous knowledge, and local knowledge generally refer to the matured long-standing traditions and practices of certain regional, indigenous, or local communities. Traditional knowledge also encompasses the local, knowledge, and teachings of these communities. In many cases, traditional knowledge has been orally passed for generations from person to person. Some forms of traditional knowledge are expressed through stories, legends, folklore, rituals, songs, and even laws. Other forms of traditional knowledge are often expressed through different means." (Sitasi dari Wikipedia, 2010) 
Dari definisi-definisi itu, kita dapat memahami bahwa kearifan lokal adalah pengetahuan yang dikembangkan oleh para leluhur dalam mensiasati lingkungan hidup sekitar mereka, menjadikan pengetahuan itu sebagai bagian dari budaya dan memperkenalkan serta meneruskan itu dari generasi ke generasi. Beberapa bentuk pengetahuan tradisional itu muncul lewat cerita-cerita, legenda-legenda, nyanyian-nyanyian, ritual-ritual, dan juga aturan atau hukum setempat.

Kearifan lokal menjadi penting dan bermanfaat hanya ketika masyarakat lokal yang mewarisi sistem pengetahuan itu mau menerima dan mengklaim hal itu sebagai bagian dari kehidupan mereka. Dengan cara itulah, kearifan lokal dapat disebut sebagai jiwa dari budaya lokal. Hal itu dapat dilihat dari ekspresi kearifan lokal dalam kehidupan setiap hari karena telah terinternalisasi dengan sangat baik. Tiap bagian dari kehidupan masyarakat lokal diarahkan secara arif berdasarkan sistem pengetahuan mereka, dimana tidak hanya bermanfaat dalam aktifitas keseharian dan interaksi dengan sesama saja, tetapi juga dalam situasi-situasi yang tidak terduga seperti bencana yang datang tiba-tiba.

Berangkat dari semua itu, kearifan lokal adalah persoalan identitas. Sebagai sistem pengetahuan lokal, ia membedakan suatu masyarakat lokal dengan masyarakat lokal yang lainnya. Perbedaan itu dapat dilihat dari tipe-tipe kearifan lokal yang dapat ditelusuri:

1. Kearifan lokal dalam hubungan dengan makanan: khusus berhubungan dengan lingkungan setempat, dicocokkan dengan iklim dan bahan makanan pokok setempat. (Contoh: Sasi laut di Maluku dan beberapa tempat lain sebagai bagian dari kearifan lokal dengan tujuan agar sumber pangan masyarakat dapat tetap terjaga).

2. Kearifan lokal dalam hubungan dengan pengobatan: untuk pencegahan dan pengobatan. (Contoh: Masing-masing daerah memiliki tanaman obat tradisional dengan khasiat yang berbeda-beda).

3. Kearifan lokal dalam hubungan dengan sistem produksi: Tentu saja berkaitan dengan sistem produksi lokal yang tradisional, sebagai bagian upaya pemenuhan kebutuhan dan manajemen tenaga kerja. (Contoh: Subak di Bali; di Maluku ada Masohi untuk membuka lahan pertanian, dll.). 
4. Kearifan lokal dalam hubungan dengan perumahan: disesuaikan dengan iklim dan bahan baku yang tersedia di wilayah tersebut (Contoh: Rumah orang Eskimo; Rumah yang terbuat dari gaba-gaba di Ambon, dll.).

5. Kearifan lokal dalam hubungan dengan pakaian: disesuaikan dengan iklim dan bahan baku yang tersedia di wilayah itu.

6. Kearifan lokal dalam hubungan sesama manusia: sistem pengetahuan lokal sebagai hasil interaksi terus menerus yang terbangun karena kebutuhan-kebutuhan di atas. (Contoh: Hubungan Pela di Maluku juga berhubungan dengan kebutuhan-kebutuhan pangan, perumahan, sistem produksi dan lain sebagainya).

\section{Tantangan Terhadap Kearifan Lokal}

Bila ada sistem pengetahuan lokal, maka ada juga sistem pengetahuan global. Apabila sistem pengetahuan lokal merupakan kategori pembeda antara suatu komunitas lokal dengan komunitas lokal yang lain, maka sistem pengetahuan global berupaya mengatasi semua pengetahuan lokal dan menjadikan semua masyarakat lokal terintegrasi ke dalam satu sistem pengetahuan saja. Apabila sistem pengetahuan lokal muncul dalam bentuk mitos-mitos tradisional, maka sistem pengetahuan global muncul pula dalam mitos-mitos modern. Salah satu mitos yang sangat terkenal, khususnya di negaranegara berkembang dan bekas jajahan adalah "pembangunan". Mitos pembangunan muncul guna membungkus ideologi "ekonomi politik pembangunan" negara-negara maju.

Definisi tentang pembangunan akan terus mengalami perubahan, disesuaikan dengan kebutuhan zaman. Tetapi pada umumnya, pembangunan diartikan sebagai suatu proses perubahan dari kondisi yang tidak baik menjadi yang lebih baik. Indikator-indikator yang menunjukkan suatu kondisi tidak baik tidak ditentukan begitu saja, tetapi ada prosesnya tersendiri. Dalam perspektif pembangunan secara umum, pembangunan ekonomi mendapatkan porsi yang lebih karena indikator kemajuan suatu negara adalah pertumbuhan ekonomi yang baik. Namun, untuk memahami pembangunan ekonomi, mesti melibatkan perspektif politik. Hal itu disebabkan karena perumusan kebijakan pembangunan merupakan proses politik yang melibatkan beragam aktor - mulai dari negara, birokrat, 
politisi, pengusaha, lembaga swadaya masyarakat hingga masyarakat itu sendiri - dengan beragam kepentingan pula, yang interaksinya bisa jadi saling berbenturan. Untuk mencapai hasil yang maksimal dalam mengatasi konflik tersebut, para aktor dituntut melakukan berbagai negosiasi dan kompromi. Dengan demikian untuk memahami kebijakan pembangunan dengan benar perlu ditelusuri secara cermat perilaku, motivasi atau pun preferensi para aktornya sehingga diperoleh jawaban: siapa memperoleh apa, berapa banyak, mengapa dan dengan cara bagaimana dari kebijakan pembangunan yang berlangsung di suatu negara dalam kurun waktu tertentu.

Dalam kerangka politik ekonomi pembangunan, kearifan lokal tidak mendapatkan tempat sama sekali karena telah disingkirkan oleh sistem pasar dan negara. Investasi demi pertumbuhan ekonomi negara adalah lebih penting daripada suatu tindakan berkelanjutan bagi masa depan manusia yang menjadi inti dari kearifan masyarakat lokal. Dalam beberapa kasus, bukan saja sistem pengetahuan lokal masyarakat yang terpinggirkan, tetapi juga masyarakat lokal secara fisik dipinggirkan atau direlokasi dengan alasan pembangunan. Selain itu, dengan alasan investasi pula, keamanan menjadi faktor penting dalam pembangunan. Struktur pengamanan dibangun sampai ke pelosok-pelosok negeri dengan melibatkan aparataparat negara yang cenderung tidak memahami cara-cara masyarakat lokal menyelesaikan sengketa di antara mereka

Masyarakat lokal yang terorganisir dengan baik dan mendapatkan tempatnya dalam sistem pemerintahan negara Indonesia adalah negeri (desa). Negeri telah lama menjadi basis pertempuran antara masyarakat vs negara, sosialisme vs kapitalisme. Secara sosio-historis, negeri-negeri pada umumnya berbasis ekonomi sosialis (prakteknya mendahului istilah). Kepemilikan tanah dikelola secara komunal dengan semangat egalitarian dan pemerataan. Hukum adat tidak mengenal kepemilikan pribadi yang mutlak, yang dapat menimbulkan ketimpangan dalam sistem masyarakat tradisional. Hak-hak ulayat atau petuanan adat atas tanah menjadi contoh penting bagaimana pengelolaan tanah itu dilakukan di negeri-negeri adat.

Masalah muncul ketika sistem desa di Jawa dipaksakan untuk diberlakukan di luar Jawa. Di Jawa, telah lama terjadi penundukkan kerajaan terhadap desa dan membuat ketimpangan ekonomi-politik. Cerita-cerita lokal yang bisa diketahui melalui 
legenda atau sejarah menunjukkan dengan jelas bahwa desa sebagai wilayah dan komunitas lokal menjadi domain mutlak kerajaan. Raja di Jawa adalah penguasa pribadi yang melakukan pengendalian dan pemilikan atas desa beserta seluruh isinya, terutama tanah dan penduduknya secara absolut. Raja memiliki hak penggunaan kekerasan dengan aparat-aparat kerajaan yang terlatih untuk melakukan tindakan represi terhadap desa. Para penguasa lokal tunduk kepada raja dan harus memberikan upeti karena semua wilayah itu adalah milik raja. Ketika sistem desa diperkenalkan ke luar Jawa, maka jiwa dan semangat sebagai klien terhadap patron itu pun terbawa ke sana. Campur tangan negara mulai nyata dan merubah hampir seluruh sistem pemerintahan adat, dengan hukum-hukum adat yang berlaku.

Kondisi itu menjadi basis yang kuat bagi kolonialisme mengembangkan sistem kapitalis dan mengeksploitasi tanah dan penduduk desa. Kolonialismelah yang membawa sistem pengetahuan modern ke negara-negara jajahan, memperkenalkan dan mempraktekannya.

\section{Posisi Kearifan Lokal Guna Pemecahan Masalah Masa Kini}

Tidak dapat dipungkiri, saat ini dunia mengalami permasalahan yang belum pernah dialami sebelumnya. Setelah

terjadi dua kali perang dunia yang meluluhlantahkan segi-segi kemanusiaan, maka sistem pengetahuan modern yang menjadikan manusia dengan kemampuan rasionya sebagai tuan atas dirinya dan dunia pun mulai dikritik. Kritik-kritik itu datang karena ketidakmampuan rasio modern mengeliminasi kehancuran-kehancuran yang ditimbulkan akibat kepentingan di balik setiap penemuan-penemuan di bidang ilmu dan teknologi.

Saat ini dunia kembali berhadapan dengan situasi lain, yaitu perubahan iklim yang tidak lagi menentu. Sekali lagi rasio modern yang menjadikan pembangunan sebagai salah satu proses penting mendapat tantangannya. Dengan alasan pembangunan, lingkungan tempat hidup manusia diobrak-abrik, kota-kota baru dibangun, tambang-tambang baru dibuka, hanya untuk memenuhi nafsu konsumsi manusia.

Pada tahap itulah, ketika manusia dengan rasio modernnya telah bingung berhadapan dengan alam karena sudah tidak mampu lagi menguasainya, kearifan lokal memperoleh tempatnya kembali. Keharmonisan dengan lingkunganlah yang dapat menjamin masa depan manusia. Hal itu tentu saja telah dibuktikan lewat proses panjang kehidupan leluhur dalam 
komunitas-komunitas lokal dalam mensiasati alam lewat budaya yang arif dan bijaksana. Dalam beberapa kasus, konflik di Maluku misalnya, ketika kemampuan pengetahuan ilmiah dalam hubungan dengan manajemen konflik sepertinya sudah tidak mampu menemukan solusi terbaik, hanya kearifan lokal yang menjadi titik balik semua itu.

\section{B. Kebudayaan Jawa}

\section{Kearifan Lokal Di Mojokerto}

Budaya Jawa mempunyai peranan penting dalam budaya Indonesia, termasuk bahasanya. Bahasa Jawa menjadi salah satu pendukung atau pemerkaya bahasa Indonesia. Tidak sedikit kosakata bahasa Jawa menjadi warga bahasa Indonesia. Untuk itu, tidak berlebihan jika bangunan bahasa Indonesia ditopang oleh bahasa Jawa. Kearifan lokal, terdiri dari dua kata yaitu kearifan (wisdom) atau kebijaksanaan dan lokal (local) atau setempat. Jadi kearifan lokal adalah gagasan setempat yang bersifat bijaksana, penuh kearifan, bernilai baik, yang tertanam dan diikuti oleh anggota masyarakatnya.

Menurut Gobyah nilai terpentingnya adalah kebenaran yang telah mentradisi atau ajeg dalam suatu daerah. Secara konseptual, kearifan lokal dan keunggulan lokal merupakan kebijaksanaan manusia yang bersandar pada filosofi nilai-nilai, etika, cara-cara dan perilaku yang melembaga secara tradisional.

Menurut Antariksa (2009), kearifan lokal merupakan unsur bagian dari tradisi-budaya masyarakat suatu bangsa, yang muncul menjadi bagian-bagian yang ditempatkan pada tatanan fisik bangunan (arsitektur) dan kawasan (perkotaan) dalam geografi kenusantaraan sebuah bangsa. Dari penjelasan beliau dapat dilihat bahwa kearifan lokal merupakan langkah penerapan dari tradisi yang diterjemahkan dalam artefak fisik. Hal terpenting dari kearifan lokal adalah proses sebelum implementasi tradisi pada artefak fisik, yaitu nilai-nilai dari alam untuk mengajak dan mengajarkan tentang bagaimana 'membaca' potensi alam dan menuliskannya kembali sebagai tradisi yang diterima secara universal oleh masyarakat, khususnya dalam berarsitektur. Nilai tradisi untuk menselaraskan kehidupan manusia dengan cara menghargai, memelihara dan melestarikan alam lingkungan. Hal ini dapat dilihat bahwa semakin adanya penyempurnaan arti dan saling mendukung, yang intinya adalah memahami bakat dan 
potensi alam tempatnya hidup; dan diwujudkannya sebagai tradisi.

Definisi kearifan lokal secara bebas dapat diartikan nilai-nilai budaya yang baik yang ada di dalam suatu masyarakat. Hal ini berarti, untuk mengetahui suatu kearifan lokal di suatu wilayah maka kita harus bisa memahami nilai-nilai budaya yang baik yang ada di dalam wilayah tersebut. Kalau mau jujur, sebenarnya nilainilai kearifan lokal ini sudah diajarkan secara turun temurun oleh orang tua kita kepada kita selaku anak-anaknya. Budaya gotong royong, saling menghormati dan tepa salira merupakan contoh kecil dari kearifan lokal.

\section{Ciri - ciri dari kearifan lokal yaitu :}

a. Mampu bertahan terhadap budaya luar,

b. Memiliki kemampuan mengakomodasi budaya luar,

c. Memiliki kemampuan mengendalikan,

d. Mempunyai kemampuan mengintegrasi unsure budaya luar ke dalam budaya asli,

e. Mampu member arah pada perkembangan budaya.

I Ketut Gobyah dalam " Berpijak pada Kearifan lokal" mengatakan bahwa kearifan lokal (local genius) adalah kebenaran yang telah mentradisi atau ajeg dalam suatu daerah. Kearifan lokal merupakan perpaduan antara nlai - nilai suci firman Tuhan dan berbagai nilai yang ada. Kearifan lokal terbentuk sebagai keunggulan budaya masyarakat setempat maupun kondisi geografi dalam arti luas. Kearifan lokal merupakan produk budaya masa lalu yang patut secara terusmenerus dijadikan pegangan hidup. Meskipun bernilai lokal tetapi nilai yang terkandung di dalamnya dianggap sangat universal.

S. Swarsi Geriya "Menggali Kearifan Lokal untuk Ajeg Bali" mengatakan bahwa secara konseptual kearifan lokal dan keunggulan lokal merupakan kebijaksanaan manusia bersandar pada filosofi nilai-nilai, etika. Cara-cara yang dianggap baik dan benar sehingga dapat bertahan dalam waktu yang lama dan bahkan melembaga.

\section{Kearifan Lokal Yang Ada Di Wonoploso Serta Makna Dan Fungsinya "Upacara Tingkeban/ Mitoni (Nujuh Bulanan)"}

Upacara Tingkeban adalah salah satu tradisi masyarakat di Wonoploso, upacara ini disebut juga mitoni berasal dari kata pitu yang arti nya tujuh, upacara ini dilaksanakan pada usia kehamilan tujuh bulan dan pada kehamilan pertama kali.Upacara ini bermakna bahwa pendidikan bukan saja setelah dewasa akan 
tetapi semenjak benih tertanam di dalam rahim ibu. Dalam upacara ini sang ibu yang sedang hamil di mandikan dengan air kembang setaman dan di sertai doa yang bertujuan untuk memohon kepada Tuhan YME agar selalu diberikan rahmat dan berkah sehingga bayi yang akan dilahirkan selamat dan sehat. Tata Cara pelaksanaan Upacara Tingkeban :

Siraman yang di lakukan oleh para sesepuh sebanyak 7 orang termasuk ayah dan ibu wanita hamil serta suami dari calon ibu. Siraman ini bermakna memohon doa restu agar proses persalinan lancar dan anak yang akan dilahirkan selamat dan sehat jasmani dan rohani.

Setelah siraman selesai, dilanjutkan dengan upacara memasukan telur ayam dan cengkir gading. Calon ayah memasukan telur ayam mentah ke dalam sarung/kain yang di kenakan oleh calon ibu melalui perut sampai pecah kemudian menyusul kedua cengkir gading di teroboskan dari atas ke dalam kain yang di pakai calon ibu sambil di terima di bawah oleh calon nenek dan kelapa gading tersebut di gendong oleh calon nenek dan di letak kan sementara di kamar. Hal ini merupakan symbol harapan semoga bayi akan lahir dengan mudah tanpa ada halangan.

\section{Upacara Mecah Kelapa}

Kelapa gading yang tadi di bawa ke kamar, kembali di gendong oleh calon nenek untuk di bawa keluar dan di letak kan dalam posisi terbalik (gambar tidak terlihat) untuk di pecah, Kelapa gading nya berjumlah 2 dan masing masing di gambari tokoh Wayang Kamajaya dan Kamaratih. Calon ayah memilih salah satu dari kedua kelapa tersebut. Apabila calon ayah memilih Kamajaya maka bayi akan lahir Laki laki, sedangkan jika memilih Kamaratih akan lahir perempuan ( hal ini hanya pengharapan saja, belum merupakan suatu kesungguhan)

\section{Dodol Rujak}

Pada upacara ini, calon ibu membuat rujak di dampingi oleh calon ayah, para tamu yang hadir membeli nya dengan menggunakan kereweng sebagai mata uang. Makna dari upacara ini agar kelak anak yang di lahirkan mendapat banyak rejeki dan dapat menghidupi keluarganya.

Selain itu ada makna lain yang tersirat dari upacara tingkeban yaitu mempererat tali silahturohmi sesama masyarakat dan juga mentradisikan budaya bangsa yang sudah ada sejak nenek moyang. 


\section{Tradisi Ruwahan}

Di desa Wonoploso juga ter dapat tradisi ruwahan berisi kegiatan melaksanakan ritual yang dilakukan pada saat datangnya bulan Ruwah atau bulan Arwah. Bagi masyarakat desa Wonoploso khususnya bulan Arwah mempunyai makna penting sebagai momentum bagi semua yang masih hidup untuk mengingat jasa dan budi baik para leluhur, tidak hanya terbatas pada orang-orang yang telah menurunkan kita, namun juga termasuk orang-orang terdekat, para pahlawan, para perintis bangsa yang telah mendahului kita pindah ke dalam dimensi kehidupan yang sesungguhnya. Bulan Arwah juga merupakan saat di mana kita harus "sesirih" atau bersih-bersih diri meliputi bersih lahir dan bersih batin. Membersihkan hati dan pikiran sebagai bentuk pembersihan dimensi jagad kecil (mikrokosmos) yakni diri pribadi kita meliputi unsur wadag dan alus, raga dan jiwa.

Tidak hanya sebatas pembersihan level mikrokosmos, selebihnya adalah bersih-bersih lingkungan alam di sekitar tempat tinggal kita, membersihkan desa, kampung, kuburan, sungai, halaman dan pekarangan di sekeliling rumah, tak lupa membersihkan semua yang membuat kotor dan jorok dalam rumah tinggal kita. Bagi petani tak luput pula bersih-bersih sawah dan ladang. Semua itu sebagai bentuk pembersihan dimensi jagad besar (makrokosmos).

Selain makna tersebut, ritual ruwahan merupakan wujud bakti dan rasa penghormatan kita sebagai generasi penerus kepada para pendahulu yang kini telah disebut sebagai leluhur. Pelaksanaan ritual ruwahan bukan tanpa konsep dan prinsip yang jelas. Ruwahan didasari oleh kesadaran spiritual masyarakat kita secara turun-temurun, di mana kita hidup saat ini telah berhutang jasa, berhutang budi baik kepada alam dan para leluhur pendahulu yang telah mendahului kita. Tak ada cara yang lebih tepat selain harus berbakti, setia dan berbakti kepada para leluhurnya yang telah mewariskan ilmu dan harta benda, termasuk bumi pertiwi, yang dapat dimanfaatkan oleh anak turunnya hingga saat ini. Ritual tradisi Ruwahan sebagai bukti kesetiaan dan sikap berbakti kepada lingkungan alam yang telah memberikan berkah berupa rejeki, tempat berlindung, hasil bumi, oksigen dan sebagainya. Karenanya hanya dengan kesetiaan serta berbakti, kita menjadi generasi penerus yang tidak mengkhianati leluhur, bangsa dan bumi pertiwinya. Berkhianat kepada para 
leluhurnya sendiri, maupun kepada bumi pertiwi di mana tempat kita menyandarkan hidup sudah pasti akan menyebabkan suatu akibat buruk. Pengkhianatan (ketidaksetiaan) dan kedurhakaan (tidak berbakti) yang dilakukan generasi penerus, akan menimbulkan kesengsaraan pada diri pribadinya (mikrokosmos) dan sangat memungkinkan tertransformasi ke dimensi makrokosmos lingkungan alamnya. Sebaliknya, kesetiaan pada bumi pertiwi yakni bumi di mana nyawa kita berpijak, kita hirup udara, kita mencari makan, dan berbakti kepada para leluhur yang menurunkan kita, merupakan satu rangkaian berupa kunci meraih kesuksesan hidup secara hakiki. Ketenangan, ketentraman, kedamaian, kesejahteraan lahir dan batin akan berlimpah menghampiri kita setiap saat.

\section{Makna Ritual dan Sajian}

Hantaran tradisi Ruwahan berisi tiga sajian makanan yakni ketan, kolak, dan apem yang ketiganya mempunyai makna masing-masing:

- ketan, makanan ini merupakan simbol eratnya tali silaturahmi, karena sifat dan bentuk ketan yang lengket.

- kolak, makanan yang diolah dengan menggunakan santan yang manis, melambangkan hubungan kekeluargaan yang selalu harmonis dan bahagia, serta mengajak persaudaraan bisa lebih 'dewasa' dan barokah penuh kemanisan.

- apem, makanan yang mempunyai arti kesediaan untuk saling memaafkan. Kata apem berasal dari bahasa arab "afwan" yang bermakna maaf.

Doa dan makan bersama (kenduri) dalam ritus nisfu sya'ban atau pada setiap malam hari selama seminggu sebelum ramadhan, merupakan bentuk dari pengejawantahan dari kebersamaan, sikap kekeluargaan, dan cara untuk memakmurkan masjid, serta meningkatkan kualitas sujud syukurnya pada Allah.

Tabur bunga merupakan bentuk dari cara masyarakat untuk selalu mengenang semua yang indah dan yang baik dari mereka yang telah mendahului. Selain itu ada kepercayaan masyarakat bahwa dengan adanya bunga di atas makam turut membantu aroma wangi pada arwah di alam kubur dan malaikat tidak sungkan mendekat. Bunga yang sering digunakan untuk nyekar adalah bunga kanthildan telasih. Bunga kanthil bermakna mengikat rasa selalu terhubung dengan para leluhur. Diharapkan dapat mencontoh perilaku baik para leluhur semasa hidupnya. Bunga kanthil berarti tansah kumanthil. Yang kumanthil adalah 
hatinya. Sukur-sukur berkahnya (safa'atnya) dapat "kanthil" (mengikuti) sumrambah mengalir ke dalam jiwa raga si peziarah. Bunga Telasih bermakna welas asih, dengan harapan dapat kawelasan atau belas kasih dari Gusti Hyang Manon. Belas kasih pula dari para leluhur yang akan njangkung dan njampangi setiap langkah kita agar tidak salah langkah menjalani proses kehidupan yang sangat pelik ini. Ziarah ke makam merupakan bentuk interpretasi dari praktik hadis yang menyatakan baha salah satu amal yang masih diterima dari orang yang sudahmeninggal adalah anak sholeh dan sholehah yang selalu mendoakan. Selain itu, ziarah juga memberikan tanda bahwa kita harus tetap mengingat leluhur kita dan saudara-saudara kita serta mengingatkan kita akan adanya kematian. Sehingga kita terangsang untuk berbuat baik.

1. Tradisi bersih kampong/desa memberikan gambaran tentang kebersamaan dan kegotongroyongan.mengingatkan kita untuk selalu saling tolongmenolong antarsesama. Selain itu bersih desa juga mengisyaratkan kepada kita tentang pentingnya lingkungan tempat di mana kita tinggal, sehingga membangun jiwa kita untuk melestarikannya.

2. Pembacaan tahlil dan yasin merupakan tanda yang menunjukkan ciri agama islam, sedangkan bentuk slametan merupakan adaptasi dari adapt istiadat sekitar yang sudah ada sebelum agama islam masuk. Slametan sendiri merupakan bentuk adaptasi dari sesaji yang dilakukan oleh para wali untuk menyebarkan agama islam di tanah jawa agar mudah diterima oleh masyarakat yang pada saa titu masih beragama Hindu dan Budha bahkan kepercayaan Animisme-Dinamisme.

\section{Ruwatan Murwakala}

\section{Makna Ruwatan}

Ruwatan adalah salah satu upacara tradisional dengan tujuan utama mendapatkan keselamatan supaya orang terbebas dari segala macam kesialan hidup, nasib jelek dan selanjutnya agar dapat mencapai kehidupan yang ayom ayem tentrem (aman, bahagia, damai di hati). Lebih konkritnya ruwatan sebagai suatu upaya membersihkan diri dari sengkala dan sukerta (dosa dan sial) yang diakibatkan dari perbuatannya sendiri, hasil perbuatan jahat orang lain maupun, Ruwatan yang paling terkenal sejak zaman kuno 
diselenggarakan oleh nenek moyang adalah ruwatan murwakala. Dalam ruwatan ini dipergelarkan wayang kulit dengan cerita Murwakala di mana orang-orang yang termasuk kategori sengkolo-sukerto diruwat atau disucikan supaya terbebas dari hukuman Betara Kala, gambaran raksasa menakutkan yang suka memangsa para sukerto.

\section{* Tradisi Ruwat}

Ritual pangruwatan dalam masyarakat di Wonoploso yang paling sering dan mudah dilakukan biasanya adalah pemagaran gaib yang dilakukan dengan menyediakan berbagai jenis sesaji dan melakukan ritual khusus. Cara di atas bisa dilakukan apabila sengkolo-sukerto yang ada masih termasuk jenis yang ringan dan mudah dibersihkan. Sementara itu untuk sengkolo-sukerto kelas berat pelaksanaan yang umum dilakukan dalam masyarakat Jawa adalah dengan menggelar pentas wayang kulit yang melakonkan tentang ruwatan itu sendiri. Sang dalang dalam menampilkan pagelarannya menyajikan salah satu dari beberapa jenis lakon. Misalnya lakon murwakala. Ruwatan dengan pagelaran wayang dilakukan sebagai suatu bentuk mendapatkan dispensasi atau keringanan hukuman. Dalam tradisi hukum positif (formal) sepadan dengan membayar denda kepada negara atau memohon grasi kepada Presiden. Dalam hal ruwatan, Bethara Kala posisinya sebagai Presiden dari bangsa lelembut. Negosiasi tertuju pada Bethara Kala sebagai salah satu eksekutor hukum alam.

Ruwatan yang paling sering dilakukan oleh masyarakat Wonoploso adalah ruwatan pada diri sendiri yang memiliki fungsi sebagai upaya membersihkan diri dari sengkala dan sukerta (dosa dan sial agar mendapatkan kebersihan jiwa.

Ruwatan untuk diri sendiri dapat dilaksanakan dengan pakem sederhana maupun dengan pakem standar yakni dengan pagelaran wayang kulit dengan lakon dan uborampe khusus ruwatan. Semua itu merupakan pilihan bagi siapa yang akan melaksanakan. Jika ruwatan dilakukan oleh orang yang memang memiliki kemampuan ekonomi yang memadai, biasanya ruwat murwakala dilakukan dengan mengadakan pagelaran wayang kulit. Pagelaran wayang kulit ini berbeda dengan pagelaran yang pada umumnya dilakukan. Pagelaran wayang kulit dilaksanakan pada siang hari dan dilakukan 
oleh dalang yang benar-benar mampu (bukan sekedar bisa) meruwat.

Dari beberapa tradisi di atas tersirat bahwa tradisi - tradisi tersebut banyak memiliki fungsi dan manfaat bagi masyarakat diantaranya masyarakat dapat membangun kebersamaan dengan meningkatkan gotong - royong dalam melaksanakan kearifan lokal, mempererat tali silahturohmi antar sesama masyarakat bahkan yang lebih baik unsur kekeluargaan tidak akan pernah hilang. Sebagian besar dari masyarakat telah mempercayai, bila tradisi ( kearifan local) tidak dilakukan dengan benar sampai - sampai tidak dilaksanakan akan terjadi suatu bencana besar, suatu misal bencana alam akan melanda kampong mereka, wabah penyakit menyerang warga, bahkan ketidaktentraman dalam diri masing - masing masyarakat

\section{Kearifan Local Masyarakat Desa}

Menurut Petrasa Wacana kearifan lokal merupakan seperangkat pengetahuan yang dikembangkan oleh suatu kelompok masyarakat setempat (komunitas) yang terhimpun dan terangkum dari pengalaman panjang manusia menggeluti alam dalam ikatan hubungan yang saling menguntungkan kedua belah pihak (manusia dan lingkungan) secara berkelanjutan dan dengan ritme yang harmonis. Kemudian kita lanjutkankan dengan kearifan lokal yang spesifik mengenai lingkungan yaitu kearifan lingkungan.Kearifan lingkungan (ecological wisdom) merupakan pengetahuan yang diperoleh dari abstraksi pengalaman adaptasi aktif terhadap lingkungannya yang khas. Pengetahuan tersebut diwujudkan dalam bentuk ide, aktivitas dan peralatan. Kearifan lingkungan yang diwujudkan ke dalam tiga bentuk tersebut dipahami, dikembangkan, dipedomani dan diwariskan secara turun-temurun oleh komunitas pendukungnya.Sikap dan perilaku menyimpang dari kearifan lingkungan, dianggap penyimpangan (deviant), tidak arif, merusak, mencemari, mengganggu dan lain-lain. Kemudian kita juga dapat menggali lebih dalam lagi mengenai kearifan lingkungan. Kearifan lingkungan dimaksudkan sebagai aktivitas dan proses berpikir, bertindak dan bersikap secara arif dan bijaksana dalam mengamati, 
mamanfaatkan dan mengolah alam sebagai suatu lingkungan hidup dan kehidupan umat manusia secara timbal balik. Kesuksesan kearifan lingkungan itu biasanya ditandai dengan produktivitas, sustainabilitas dan equtablitas atau keputusan yang bijaksana, benar, tepat, adil, serasi dan harmonis.

Menurut Munsi Lampe melalui artikelnya yang berjudul "Kearifan Tradisional Lingkungan Belajar dari Kasus Komunitas-Komunitas Petani dan Nelayan Tradisional" Kearifan lingkungan di Indonesia menjadi topik perbincangan yang menarik, bahkan mendesak kepentingannya sehubungan dengan isu program rehabilitasi dan pengelolaan lingkungan, khususnya lingkungan ekosistem laut (mangrof dan terumbu karang) yang mengalami kerusakan pada hampir semua daerah perairan pantai dan pulau - pula, yang menurut hasil penelitian, banyak diakibatkan oleh perilaku pemanfaat, terutama komunitas-komunitas nelayan itu sendiri.

Haryati Soebadio berpendapat bahwa kearifan lokal adalah suatu identitas/kepribadian budaya bangsa yang menyebabkan bangsa tersebut mampu menyerap dan mengolah kebudayaan asing sesuai watak dan kemampuan sendiri.

Menurut Rahyono (2009:7) kearifan lokal merupakan kecerdasan manusia yang dimiliki oleh kelompok etnis tertentu yang diperoleh melalui pengalaman masyarakat. Artinya, kearifan lokal adalah hasil dari masyarakat tertentu melalui pengalaman mereka dan belum tentu dialami oleh masyarakat yang lain. Nilai-nilai tersebut akan melekat sangat kuat pada masyarakat tertentu dan nilai itu sudah melalui perjalanan waktu yang panjang, sepanjang keberadaan masyarakat tersebut.

Definisi kearifan lokal tersebut, paling tidak menyiratkan beberapa konsep, yaitu:

a. Kearifan lokal adalah sebuah pengalaman panjang, yang diendapkan sebagai petunjuk perilaku seseorang;

b. Kearifan lokal tidak lepas dari lingkungan pemiliknya;

c. Kearifan lokal itu bersifat dinamis, lentur, terbuka, dan senantiasa menyesuaikan dengan zamannya.

Menurut Wahyu dalam Mukti (2010) bahwa kearifan lokal, dalam terminology budaya, dapat diinterpretasikan sebagai pengetahuan lokal yang berasal dari budaya masyarakat, yang unik, mempunyai hubungan dengan alam 
dalam sejarah yang panjang, beradaptasi dengan sistem ekologi setempat, bersifat dinamis dan selalu terbuka dengan tambahan pengetahuan baru. Secara lebih spesifik, kearifan lokal dapat diartikan sebagai suatu pengetahuan lokal, yang unik yang berasal dari budaya atau masyarakat setempat, yang dapat dijadikan dasar pengambilan keputusan pada tingkat lokal dalam bidang pertanian, kesehatan, penyediaan makanan, pendidikan, pengelolaan sumberdaya alam dan beragam kegiatan lainnya di dalam komunitas-komunitas.

Jadi, dapat disimpulakan kearifan lokal adalah , kearifan lokal dapat diartikan sebagai suatu pengetahuan lokal, yang unik yang berasal dari budaya atau masyarakat setempat, yang dapat dijadikan dasar pengambilan keputusan pada tingkat lokal dalam bidang pertanian, kesehatan, penyediaan makanan, pendidikan, pengelolaan sumberdaya alam dan beragam kegiatan lainnya di dalam komunitaskomunitas.

\section{Ruang Lingkup Kearifan Lokal}

Kearifan lokal merupakan fenomena yang luas dan komprehensif. Cakupan kearifan lokal cukup banyak dan beragam sehingga sulit dibatasi oleh ruang. Kearifan tradisional dan kearifan kini berbeda dengan kearifan lokal. Kearifan lokal lebih menekankan pada tempat dan lokalitas dari kearifan tersebut sehingga tidak harus merupakan sebuah kearifan yang telah diwariskan dari generasi ke generasi. Kearifan lokal bisa merupakan kearifan yang belum lama muncul dalam suatu komunitas sebagai hasil dari interaksinya denganlingkungan alam dan interaksinya dengan masyarakat serta budaya lain. Oleh karena itu, kearifan lokal tidak selalu bersifat tradisional karena dia dapat mencakup kearifan masa kini dan karena itu pula lebih luas maknanya daripada kearifan tradisional.

Untuk membedakan kearifan lokal yang baru saja muncul dengan kearifan lokal yang sudah lama dikenal komunitas tersebut, dapat digunakan istilah: kearifan kini, kearifan baru, atau kearifan kontemporer. Kearifan tradisional dapat disebut kearifan dulu atau kearifan lama.

\section{Fungsi Kearifan Lokal}

Kearifan lokal merupakan salah satu warisan dari nenek moyang, warisan tersebut bisa berupa tata nilai kehidupan yang menyatu dalam bentuk religi, budaya 
ataupun adat istiadat (Basuni, 2012). Keberadaan kearifan lokal ini bukan tanpa fungsi. Kearifan lokal sangat banyak fungsinya.

Seperti yang dituliskan Sartini (2006), bahwa fungsi kearifan lokal adalah sebagai berikut:

- Berfungsi untuk konservasi dan pelestarian sumber daya alam.

- Berfungsi untuk pengembangan sumber daya manusia.

- Berfungsi untuk pengembangan kebudayaan dan ilmu pengetahuan.

- Berfungsi sebagai petuah, kepercayaan, sastra dan pantangan.

- Bermakna sosial misalnya upacara integrasi komunal/kerabat.

- Bermakna sosial, misalnya pada upacara daur pertanian

- Bermakna etika dan moral.

- Bermakna politik,

kearifan lokal yang terkait dengan kebudayaan, memiliki arti penting untuk menjaga keberlanjutan kebudayaan, sekaligus agar selalu terjaga kelestariannya. Terlebih lagi, di tengah-tengah modernisasi yang istilahnya saat ini lebih akrab dikenal sebagai globalisasi. Yang dalam kenyataannya, globalisasi itu dapat menggeser nilai-nilai budaya lokal oleh nilai budaya asing yang berkembang begitu pesat di dalam kehidupan masyarakat di Indonesia, baik yang hidup di perkotaan maupun perdesaan (Puslitbangbud, 2011).

Pelestarian kearifan lokal dengan sendirinya akan dapat melestarikan lingkungan perdesaan. Karena, nilai-nilai kearifan lokal tersebut akan menjadikan masyarakat memiliki karakter kuat sesuai dengan budaya dan norma yang berlaku di lingkungannya. Selain itu, desa-desa yang berbatasan langsung dengan kawasan konservasi akan menjaga kelestarian kawasan konservasi karena biasanya kawasan tersebut erat kaitannya dengan nilai-nilai kearifan lokal yang dianut. Kegiatan konservasi di suatu wilayah sebaiknya berasal dari kesadaran masyarakat yang berada di wilayah yang bersangkutan. Kesadaran akan pentingnya menjaga keanekaragaman hayati sangat diperlukan tidak saja untuk kepentingan bangsa Indonesia melainkan juga untuk kepentingan masyarakat dunia secara keseluruhan dan 
diarahkan untuk kepentingan jangka panjang (Aulia \& Dharmawan, 2010)

Peranan kearifan lokal dalam kelestarian lingkungan perdesaan dapat kita temukan contoh kasusnya pada kampung-kampung adat seperti Baduy, Kampung Kuta, Kampung Naga, dsb. Di daerah tersebut, lingkungan perdesaan dan hutan yang berbatasan langsung sangat terjaga kelestariannya, masyarakat dapat memanfaatkan hutan dan sumber daya yang terkandung di dalamnya namun tetap dapat menjaga kelestarian dari hutan tersebut karena terikat oleh nilai-nilai kearifan local

\section{Pendekatan Kearifan Lokal}

Dalam belajar kearifan lokal khususnya dan kearifan lingkungan pada umumnya maka penting untuk mengerti :

a. Politik Ekologi (Political Ecology)

Politik ekologi sebagai suatu pendekatan, yaitu upaya untuk mengkaji sebab akibat perubahan lingkungan yang lebih kompleks daripada sekedar sistem biofisik yakni menyangkut distribusi kekuasaan dalam satu masyarakat. Pendekatan ini didasarkan pada pemikiran tentang beragamnya kelompok-kelompok kepentingan, persepsi dan rencana yang berbeda terhadap lingkungan. Melalui pendekatan politik ekologi dapat untuk melihat isu-isu pengelolaan lingkungan khususnya menyangkut isu "right to environment dan environment justice" dimana right merujuk pada kebutuhan minimal/standarindividu terhadap obyek-obyek right seperti hak untuk hidup, hak untuk bersuara, hak untuk lingkungan dan lain-lain. Adapun justice menekankan alokasi pemilikan dan penguasaan atas obyek-obyek right yaitu merujuk pada persoalan-persoalan relasional antar individu dan antar kelompok (Bakti Setiawan, 2006).

Konsep right to environment dan environment justice harus mempertimbangkan prinsipprinsip keadilan diantara generasi (intra-generational justice) dan lintas generasi (inter-generational justice), karena konsep pembangunan berkelanjutan menekankan baik dimensi diantara generasi maupun lintas generasi. 
b. Human Welfare Ecology

Pendekatan Human Welfare Ecology menurut Eckersley, 1992 dalam Bakti Setiawan, 2006 menekankan bahwa kelestarian lingkungan tidak akan terwujud apabila tidak terjamin keadilan lingkungan, khususnya terjaminnya kesejahteraan masyarakatnya.

Maka dari itu perlu strategi untuk dapat menerapkannya antara lain :

a. Strategi pertama, melakukan perubahan struktural kerangka perundangan dan praktek politik pengelolaan sumberdaya alam, khususnya yang lebih memberikan peluang dan kontrol bagi daerah, masyarakat lokal dan petani untuk mengakses sumberdaya alam (pertanahan, kehutanan, pertambangan, kelautan). Dalam hal ini lebih memihak pada masyarakat lokal dan petani dan membatasi kewenangan negara yang terlalu berlebihan (hubungan negara kapital masyarakat sipil).

b. Strategi kedua, menyangkut penguatan institusi masyarakat lokal dan petani

c. Pendekatan Ekosistemik

Pendekatan ekosistemik melihat komponen-komponen manusia dan lingkungan sebagai satu kesatuan ekosistem yang seimbang dan

d. Pendekatan Aksi dan Konsekuensi (Model penjelasan Konstekstual Progressif)

Model ini lebih aplikatif untuk menjelaskan dan memahami fenomena-fenomena yang menjadi pokok masalahnya. Kelebihan dari pendekatan ini adalah mempunyai asumsi dan model penjelasan yang empirik, menyediakan tempattempat dan peluang bagi adopsi asumsi-asumsi dan konsepkonsep tertentu yang sesuai.

Selanjutnya Vayda dalam Su Ritohardoyo (2006:25) menjelaskan bahwa pendekatan kontekstual progressif lebih menekankan pada obyek-obyek kajian tentang :
a. aktivitas manusia dalam hubungan dengan lingkungan
b. penyebab terjadinya aktivitas dan
c. akibat-akibat aktivitas baik terhadap lingkungan maupun terhadap manusia sebagai pelaku aktivitas.




\section{Kearifan Lokal dalam Pengelolaan Lingkungan}

Sejarah peradapan telah menunjukkan betapa usaha manusia untuk meningkatkan kesejahteraan hidupnya telah menimbulkan kesengsaraan berupa bencana alam yang disebabkan karena manusia tidak mampu mengendalikan ketamakannya.Mengalami hal tersebut, manusia mulai berfikir dan bekerja secara aktif untuk memahami lingkungannya yang memberikan tantangan dan mengembangkan cara-cara yang paling menguntungkan dalam upaya memenuhi kebutuhan hidup yang terus cenderung meningkat dalam jumlahnya, ragam dan mutunya.

Manusia berusaha memahami alam semesta beserta isinya, memilah-milah gejala yang nampak nyata atau tidak nyata ke dalam sejumlah kategori untuk mempermudah mereka dalam menghadapi alam secara lebih efektif.Dengan kemampuan bekerja dan berfikir secara metaforik, manusia tidak lagi mengandalkan naluri dalam beradaptasi dengan lingkungan.Ia mulai secara aktif mengolah sumberdaya alam dan mengelola lingkungan sesuai dengan resep-resep budaya yang merupakan himpunan abstraksi pengalaman mereka menghadapi tantangan. Manusia dalam beradaptasi, mengembangkan kearifan lingkungan yang berwujud ideasional berupa pengetahuan atau ide, norma adat, nilai budaya, aktifitas serta peralatan, sebagai hasil abstraksi pengalaman yang dihayati oleh segenap masyarakat pendukungnya dan yang menjadi pedoman atau kerangka acuan untuk melihat, memahami, memilah-milah gejala yang dihadapi serta memilih strategi bersikap maupun bertindak dalam mengelola lingkungan.

Keanekaragaman pola-pola adaptasi manusia terhadap lingkungan, terkadang tidak mudah dimengerti oleh pihak ketiga yang mempunyai latar belakang sosial dan kebudayaan yang berbeda.Namun demikian, keanekaragaman pola-pola adaptasi terhadap lingkungan tersebut merupakan faktor yang harus diperhitungkan dalam perencanaan dan pelaksanaan pembangungan yang berkelanjutan.

Masyarakat Indonesia dengan ribuan komunitas mengembangkan kearifan lokal sesuai dengan karakterisktik lingkungan yang khas. Secara suku bangsa terdapat lebih kurang 555 suku bangsa atau sub suku bangsa yang tersebar di wilayah Kepulauan Nusantara. Dalam beradaptasi terhadap 
lingkungan, kelompok-kelompok masyarakat tersebut mengembangkan kearifan lingkungan sebagai hasil abstraksi pengalaman mengelola lingkungan.Sering kali pengetahuan mereka tentang lingkungan setempat sangat rinci dan menjadi pedoman yang akurat bagi masyarakat yang mengembangkan kehidupan di lingkungan pemukiman mereka.Pengetahuan rakyat itu biasanya berbentuk kearifan yang sangat dalam maknanya dan sangat erat kaitannya dengan pranata kebudayaan, terutama pranata kepercayaan (agama) dan hukum adat yang kadang-kadang diwarnai dengan mantra-mantra.Ia merupakan kumpulan abstraksi pengalaman yang dihayati oleh segenap anggota masyarakat pendukungnya dan menjadi pedoman atau kerangka acuan untuk melihat, memahami dan memilah-milah gejala yang dihadapi serta memilih strategi dalam bersikap maupun bertindak dalam mengelola lingkungan. Perbedaan acuan, pandangan/penilaian, standar, ukuran atau kriteria tersebut, dapat menimbulkan benturan atau konflik antara masyarakat lokal dengan pengusaha maupun pemerintah.Padahal, pembangunan berkelanjutan memungkinkan pemanfaatan kearifan dan sumber-sumber daya sosial sebagai modal dalam pelestarian fungsi lingkungan hidup. Kurangnya perlindungan atau penghormatan terhadap kearifan lingkungan yang dikembangkan masyarakat lokal dalam pengelolaan lingkungan hidup dan pemanfaatan sumber daya alama, antara lain disebabkan oleh kurangnya pemahaman para pihak terkait (stakeholders) dan tidak bersedianya informasi mengenai kearifan lingkungan. Sejumlah konflik yang muncul mengenai lingkungan lebih banyak melibatkan masyarakat adat dengan masyaralat lain yang tidak mengalami kearifan lokal dan adat suatu masyarakat tentang bagaimana masyarakat tersebut mengelola lingkungannya secara tradisional termasuk pelanggaran pemilikan tanah secara adat. Karena itu, langkah yang tepat dalam usaha untuk mewujudkan kearifan lingkungan adalah dengan mengkaji kembali tragedi yang ada di masyarakat tentang usaha mereka untuk mewujudkan keseimbangan kehidupannya dengan lingkungannya. Tradisi dan aturan lokal yang tercipata dan diwariskan turun menurun untuk mengelola lingkungan, dapat merupakan materi penting bagi penyusunan kebijakan yang baru tentang lingkungan. Norma- 
norma yang mengatur kelakuan manusia dalam berinteraksi dengan lingkungannya, ditambah dengan kearifan ekologi tradisional yang mereka miliki, merupakan etika lingkungan yang mempedomani perilaku manusia dalam mengelola lingkungannya.

Kriteria kearifan lokal yang terkait dengan perlindungan dan pengelolaan lingkungan hidup (Perlindungan dan Pengelolaan Lingkungan Hidup) terdiri dari:

a. Nilai-Nilai luhur yang berlaku dalam tata kehidupan masyarakat

b. Melindungi dan mengelola lingkungan hidup secara lestari dan berkelanjutan.

Kriteria Pengetahuan Tradisional (PT) terkait Perlindungan dan Pengelolaan Lingkungan Hidup (Harry Alexander dan Miranda Risang Ayu, 2011), secara garis-besar, adalah:

- Dihasilkan, direpresentasikan, dikembangkan, dilestarikan, dan ditransmisikan dalam konteks tradisional dan antargenerasional,

- Secara nyata dapat dibedakan, atau diakui menurut kebiasaan, sebagai berasal dari suatu komunitas masyarakat hukum adat, yang melestarikan dan mentransmisikan Pengetahuan Tradisional (PT) tersebut dari generasi ke generasi, dan terus menggunakan dan mengembangkannya dalam konteks tradisional di dalam komunitas itu sendiri,

- Merupakan bagian integral dari indentitas budaya suatu masyarakat hukum adat, yang dikenal dan diakui sebagai pemegang hak atas Pengetahuan Tradisional (PT) itu melalui aktivitas pemangkuan, penjagaan, pemilikan kolektif, maupun tanggung-jawab budaya. Kaitan antara Pengetahuan Tradisional (PT) dan pemangkunya ini dapat diungkapkan, baik secara formal atau informal, melalui praktek-praktek kebiasaan atau praktek-praktek tradisional, protokol, atau hukum nasional yang berlaku.

- Diwariskan dari generasi ke generasi, meski pun pemakaiannya mungkin tidak terbatas lagi di dalam komunitas terkait saja. 


\section{Kearifan Lokal dalam Pengelolaan Sumber Daya Alam}

Masyarakat setempat yang menerapkan cara hidup tradisional di daerah pedesaan, yang nyaris tak tersentuh teknologi umumnya dikenal sebagai masyarakat suku, komunitas asli atau masyarakat hukum adat, penduduk asli atau masyarakat tradisional. Masyarakat setempat seringkali menganggap diri mereka sebagai penghuni asli kawasan terkait, dan mereka biasanya berhimpun dalam tingkat komunitas atau desa. Kondisi demikian dapat menyebabkan perbedaan rasa kepemilikan antara masyarakat asli/pribumi dengan penghuni baru yang berasal dari luar, sehingga masyarakat setempat seringkali menjadi rekan yang tepat dalam konservasi.

Di sebagian besar penjuru dunia, semakin banyak masyarakat setempat telah berinteraksi dengan kehidupan modern, sehingga sistem nilai mereka telah terpengaruh, dan diikuti penggunaan barang dari luar. Pergeseran nilai akan beresiko melemahnya kedekatan masyarakat asli dengan alam sekitar, serta melunturkan etika konservasi setempat. Masyarakat tradisional pada umumnya sangat mengenal dengan baik lingkungan di sekitarnya. Mereka hidup dalam berbagai ekosistem alami yang ada di Indonesia, dan telah lama hidup berdampingan dengan alam secara harmonis, sehingga mengenal berbagai cara memanfaatkan sumberdaya alam secara berkelanjutan.

Masyarakat pedusunan memiliki keunikan khusus seperti kesederhanaan, ikatan emosional tinggi, kesenian rakyat dan loyalitas pada pimpinan kultural seperti halnya konsep-konsep yang berkembang di pedusunan sebagai seluk beluk masyarakat jawa akan pemahamannya pada : i) Gusti Allah, 2) Ingkang Akaryo jagad, 3) Ingkang Murbeng Dumadi, 4) Hyang Suksma Adiluwih, 5) Hyang maha Suci, 6) Sang Hyang Manon, 7) Agama Ageman Aji, dan 8) Kodrat Wiradat. Semua itu menjadi pedoman bagi orang Jawa dalam berperilaku, sehingga selalu mempertimbangkan pada besarnya Kekuasaan Gusti Allah dan harus menjaga apa saja yang telah diciptakannya. Di samping itu dalam berperilaku orang akan berpedoman pada berbagai macam hal yang pada hakekatnya mempunyai nilai baik dan buruk serta pada kegiatan yang didasarkan pada benar dan salah. 
Dalam kearifan lokal juga terwujud upaya pengelolaan sumberdaya alam dan lingkungan yang juga merupakan wujud dari konservasi oleh masyarakat. Berkaitan dengan hal itu, maka Nababan dalam Suhartini (2009) mengemukakan prinsip-prinsip konservasi dalam pengelolaan sumberdaya alam secara tradisional sebagai berikut :

- Rasa hormat yang mendorong keselarasan (harmoni) hubungan manusia dengan alam sekitarnya. Dalam hal ini masyarakat tradisional lebih condong memandang dirinya sebagai bagian dari alam itu sendiri

- Rasa memiliki yang eksklusif bagi komunitas atas suatu kawasan atau jenis sumberdaya alam tertentu sebagai hak kepemilikan bersama (communal property resource). Rasa memiliki ini mengikat semua warga untuk menjaga dan mengamankan sumberdaya bersama ini dari pihak luar.

- Sistem pengetahuan masyarakat setempat (lokal knowledge sistem) yang memberikan kemampuan kepada masyarakat untuk memecahkan masalah-masalah yang mereka hadapi dalam memanfaatkan sumberdaya alam yang terbatas.

- Daya adaptasi dalam penggunaan teknologi sederhana yang tepat guna dan hemat (input) energi sesuai dengan kondisi alam setempat

- Sistem alokasi dan penegakan aturan-aturan adat yang bisa mengamankan sumberdaya milik bersama dari penggunaan berlebihan, baik oleh masyarakat sendiri maupun oleh masyarakat luar (pendatang). Dalam hal ini masyarakat tradisional sudah memiliki pranata dan hukum adat yang mengatur semua aspek kehidupan bermasyarakat dalam satu kesatuan sosial tertentu.

- Mekanisme pemerataan (distribusi) hasil panen atau sumber daya milik bersama yang dapat mencegah munculnya kesenjangan berlebihan di dalam masyarakat tradisional. Tidak adanya kecemburuan atau kemarahan sosial akan mencegah pencurian atau penggunaan sumberdaya di luar aturan adat yang berlaku.

Contoh kearifan lokal dalam pengelolaan sumber daya alam dari beberapa daerah yang ada di nusantara:

a. Kearifan lokal masyarakat Suku Bajo terkait pemanfaatan sumber daya di laut Suku Bajo memiliki nilai-nilai dan norma yang mengatur kehidupan mereka. Kearifan lokal tersebut membuat Suku Bajo mampu bertahan hingga 
sekarang. Kearifan dan pengetahuan lokal tersebut merupakan hasil dari proses yang sangat panjang dari generasi ke generasi. Beberapa kearifan lokal Suku Bajo dalam memperlakukan lingkungannya dapat dilihat padacontoh di bawah ini.

Suku Bajo memiliki kegiatan yang dinamakan Bapongka atau biasa juga disebut babangi. Bapongka merupakan istilah untuk kegiatan melaut selama beberapa minggu bahkan bulan dengan perahu berukuran kurang lebih 4 x 2 meter yang disebut Leppa dengan mengikutsertakan anak istri (Alwiah dan Utina, 2013).

Selama Bapongka terdapat suatu kearifan yang sangat bermanfaat bagi kelestarian lingkungan perairan yaitu berupa larangan atau pamali untuk:

a. Tidak boleh membuang air bekas cucian beras

b. Arang kayu bekas memasak,

c. Ampas kopi,

d. Air cabe,

e. Air jahe,

f. Kulit jeruk, dan

g. Abu dapu

Suku bajo dari sejak jaman dahulu sudah mulai memiliki pemahaman jika membuang sampah dapat mencemari lingkungan. Meskipun, sampah yang dibuang merupakan sampah organik dan tidak terlalu memberikan dampak negatif bagi perairan, namun nilai-nilai tersebut perlu dilestarikan dan mungkin direvitalisasi dengan penguatan dan penambahan pemahaman agar larangan membuang limbah berlaku tidak hanya kepada ketujuh benda yang telah disebutkan di atas, namun juga terhadap seluruh limbah dari produk modern yang dibawa ketika Bapongka.

Selain larangan dalam membuang tujuh jenis limbah ketika yang telah disebutkan pada poin sebelumnya, terdapat pamali lain yang ternyata juga memiliki nilai kelestarian lingkungan. Pamali tersebut adalah larangan untuk menangkap ikan yang berukuran kecil dan memakannya Mereka hanya boleh mengkonsumsi ikan yang memiliki ukuran besar atau layak panen. Norma lain yang berlaku adalah menghormati laut. Suku Bajo sangat menghormati laut karena merupakan sumber penghidupannya. Bagi Suku bajo pamali untuk mengucapkan kata-kata yang tidak pantas atau 
mengumpat di laut. hal tersebut menunjukkan betapa Suku Bajo sangat menghargai laut. Suku Bajo sangat takut melanggar pamali. Mereka beranggapan akan mendatangkan malapetaka dan musibah apabila melanggar pamali. Malapetaka atau musibah tersebut dapat datang dalam berbagai bentuk seperti tidak memperoleh ikan, badai, ombak besar, dsb

b. Kearifan lokal masyarakat di Desa Rumbio Kecamatan Kampar

Kearifan lokal suatu daerah atau tempat berbeda-beda. Misalnya untuk menjaga kelestarian hutan di Desa Rumbio Kecamatan Kampar Propinsi Riau dengan cara membuat hutan larangan adat, yaitu melestarikan hutan bersamasama di dalam masyarakat tersebut dan masyarakat dilarang menebang di hutan larangan adat tersebut. Jika dilanggar akan dikenakan denda seperti, beras $100 \mathrm{~kg}$ atau berupa uang sebanyak Rp 6 juta.

c. Kearifan lokal masyarakat Desa Claket

Berbeda dengan desa Claket, Kecamatan Pacet, Kabupaten Mojokerto ada kearifan lokal dalam melestarikan sumber air yaitu dengan upacara "bersih desa", yaitu berjalan bersama-sama seluruh warga desa sambil membawa makanan menuju sumber mata air Claket. Setelah sampai pada sumber mata air, diadakan acara "Selamatan" seluruh warga sebagai ungkapan rasa syukur kepada Tuhan atas karunia-Nya berupa sumber air sehingga dapat memberi penghidupan seluruh warga yang sehari sebelumnya tempat tersebut dibersihkan terlebih dahulu dan ditanami pohon.

Hampir sama seperti di Jawa, untuk menjaga kelestarian hutan di bali khususnya di Desa Penglipuran bentuk kearifan lokal masarakat setempat yaitu adanya konsep "Hutan Due" yang telah disahkan pada awig-awig (peraturan) desa. Konsep "Hutan Due" yang berarti hutan yang dikeramatkan oleh masyarakat setempat. Kayu atau pun hasil hutan yang ada di hutan itu hanya bisa digunakan untuk keperluan upacara adat. Jika ada orang yang mengambil hasil hutan pada hutan tersebut untuk kepentingan pribadi tanpa sepengetahuan aparat desa, 
maka akan dikenakan sangsi sesuai awig-awig yang telah disepakati.

d. Kearifan lokal masyarakat Bali

Sedangkan untuk masarakat bali pada umumnya untuk melestarikan hutan dengan cara mengadakan perayaan hari Tumpek Pengatag yang diadakan setiap 210 hari sekali. Pada upacara ini mengajarkan pada umat manusia bahwa kita wajib bersyukur atas harmoni yang membantu kita tinggal dalam alam kehidupan kini. Menghormati dan menghargai bumi dan seisinya, khususnya tanaman yang ada, memberi isyarat dan makna mendalam agar manusia mengasihi dan menyayangi alam dan lingkungan yang telah berjasa menopang hidup dan penghidupannya

Kalau kita pandang dari segi sosial masyarakat bahwa kearifan lokal itu merupakan media pembelajaran bagi masyarakat untuk belajar saling menghormati dan saling menyayangi. Baik sesama manusia maupun terhadap lingkungan.

e. Kearifan lokal masyarakat Minangkabau

Di Propinsi Sumatera Barat yang sering juga disebut dengan Ranah Minang, juga terdapat beberapa jenis Kearifan Lokal yang berkaitan dengan pengelolaan Hutan Tanah dan Air diantaranya Rimbo Larangan, Banda Larangan, Tabek Larangan, Mamutiah Durian, Parak, Menanam Tanaman Keras sebelum Nikah, Goro Basamo dan masih banyak lagi yang lainnya.

- Rimbo Larangan (Hutan Larangan )

Yaitu hutan yang menurut aturan adat tidak boleh ditebang karena fungsinya yang sangat vital sekali sebagai persediaan air sepanjang waktu untuk keperluan masyarakat, selain itu kayu yang tumbuh dihutan juga dipandang sebagai perisai untuk melindungi segenap masyarakat yang bermukim disekitar hutan dari bahaya tanah longsor. Apabila ada terdapat diantara warga yang akan membuat rumah yang membutuhkan kayu, maka harus minta izin lebih dulu kepada aparat Nagari melalui para pemangku adat untuk menebang kayu yang dibutuhkan dengan peralatan Kapak dan Gergaji tangan. 
- Banda Larangan ( Sungai, Anak Sungai / Kali Larangan )

Merupakan suatu aliran sungai yang tetap dijaga agar tidak tercemar dari bahan atau benda yang bersifat dapat memusnahkan segenap binatang dan biota lainnya yang ada di aliran sungai sehingga tidak menjadi punah, seperti halnya warga masyarakat tidak boleh menangkap ikan dengan cara Pengeboman, memakai racun, memakai aliran listrik dan lain sebagainya. Untuk panen Ikan dari Banda Larangan tersebut, pihak Pemangku Adat dan Aparat Nagari melaksanakan dengan cara membuka larangan secara bersama-sama masyarakat untuk kepentingan bersama dan hasilnya selain untu masyarakat juga sebahagian untuk KAS Nagari. Biasanya Banda Larangan ini dibuka sekali setahun atau sekali dua tahun tergantung kesepakatan Para Pemangku Adat.

- Tabek Larangan ( tebat larangan )

Yaitu Kolam air yang dibuat secara bersama oleh masyarakat pada zaman dulu dengan tujuan untuk persediaan air bagi kepentingan masyarakat dan didalam Tabek tersebut juga dipelihara berbagai jenis ikan, saat untuk membuka Tabek Larangan tersebut sama dengan seperti di Banda Larangan.

- Mamutiah durian (memutih durian)

Yaitu kegiatan menguliti pohon durian apabila kedapatan salah seorang warga masyarakat pemilik pohon durian yang memanjat dan memetik buah durian sebelum durian itu matang, hal itu dilakukan sebagai sanksi moral bagi masyarakat yang melakukannya karena dipandang tidak mempunyai rasa sosial antar sesama. Setelah pohon Durian dikuliti maka secara berangsur pohon itu akan mati. Biasanya pemilik pohon durian akan mendapatkan hasil semenjak matahari terbit sampai terbenam, sedangkan disaat malam hari buah durian yang jatuh telah menjadi milik bersama.

- Parak

yaitu suatu lahan tempat masyarakat berusaha tani dimana terdapat keberagaman jenis tanaman yang 
dapat dipanen sepanjang waktu secara bergiliran, sehingga pada lahan parak ini terdapat nilai ekonomi yang yang berkelanjutan. Apabila dilihat dari jauh, parak di pandang seolah-olah seperti hutan dan juga berfungsi sebagai penyangga bagi daerah dibawahnya

f. Kearifan lokal masyarakat Desa Ciomas, Jawa Barat Masyarakat di Desa ini memiliki satu kearifan lokal warisan nenek moyang mereka mengenai pelestarian lingkungan yang sampai saat ini masih dengan teguh mereka jaga. Salah satunya adalah dengan masih menetapkannya Leuweung Larangan (hutan larangan) di kawasan Gunung Sawal sebagai tempat yang harus betul-betul dijaga kelestariannya.

Di samping itu, ada pula beberapa tahapan dalam adat masyarakat Ciomas yang mengedepankan pola-pola sistematis dan bertahap dalam hal pelestarian hutan di lingkungan mereka. Tahapan adat itu terbagi dalam tiga tahap yang begitu sistematis dan penuh perhitungan.

Inilah tahap-tahap dalam adat Masyarakat Ciomas dalam hal menjaga lingkungan hutan agar tetap lestari:

- Kabarataan

Kabarataan adalah sebuah adat yang mengedepankan pada analisis yang mendalam terhadap kerusakankerusakan hutan yang terdapat dalam tata wilayah mereka. Dalam adat Kabarataan ini meliputi menghitung berbagai kerusakan hutan, menetapkan waktu pemulihan kerusakan tersebut (Tata Wayah) dan juga rancangan kerja tentang apa-apa saja yang harus dilakukan untuk memulihkan kerusakan (Tata Lampah). Tidak hanya itu, dalam adat Kabarataan ini juga diadakan upacara penanaman pohon panayogian atau penanda yang disebut dengan nama Ki Pasang, mengingat pohon yang di tanam adalah dua jenis pohon yang sama dan berdampingan. Dalam prosesi adat menanam pohon panayogian biasanya dilakukan pada akhir menjelang rangkaian adat Kabarataan berakhir. Yang membuat saya terkesan adalah, untuk pohon yang di tanam dalam Panayogian ini masyarakat adat mewajibkan untuk hanya menanam jenis pohon yang tumbuh di wilayah itu dan sama 
sekali tidak dibolehkan untuk menanam pohon yang berasal dari luar daerah tersebut. Hal itu tentu saja dilakukan bukan dengan tanpa alasan sama sekali.

Tujuan utama dari penanaman pohon yang harus dari wilayah tersebut dengan perhitungan bahwa adaftasi sebuah tanaman dengan tanah dan lingkungan baru adakalanya memakan proses yang tidak selamanya berjalan mulus. Jika pohon yang ditanam merupakan tanaman asli dari wilayah tersebut maka diharapkan proses adaptasi dan pertumbuhan dari sang pohon yang baru di tanam bisa lebih mudah dilalui

- Kadewaan

Untuk tahapan berikutnya setelah prosesi adat Kabarataan berakhir maka dilanjutkan dengan tahapan selanjutnya yakni melaksanakan adat Kadewaan. Kadewaan sendiri pada prinsipnya adalah awal dimulainya proses pemulihan hutan dan lingkungan termasuk mata air, sungai, dan aneka tumbuhan di sekitar wilayah tersebut yang pada saat adat Kabarataan dianggap sudah waktunya dipulihkan dari kerusakan-kerusakan. Maka, jika dalam adat Kabarataan adalah berupa analisis yang mendalam untuk mendeteksi kerusakan-kerusakan lingkungan berikut dengan pola-pola apa saja yang akan diambil dalam upaya penyembuhan lingkungan yang rusak tersebut, maka dalam adat Kadewaan ini adalah upaya pelaksanaan dari pemulihan itu sendiri. Dalam Kadewaan ini, masyarakat diwajibkan untuk menanam pohon di tempat-tempat yang dianggap telah rusak. Dan seperti pada adat Kabarataan, pohon-pohon yang ditanam di sini pun harus berasal dari jenis pohon yang ada di wilayah tersebut.

- Karatuan

Untuk tahapan terakhir dari rangkaian adat ini adalah pelaksanaan adat karatuan. Adat Karatuan adalah sebuah proses berkesinambungan antara terus memulihkan lingkungan dan juga menjaga keberlangsungan pemulihan itu sendiri hingga tercapai sebuah tata lingkungan yang benar-benar subur, bersahabat dan tentu saja bisa diambil manfaatnya oleh penduduk setempat. Maka dari itu, 
dalam adat karatuan ini sifatnya jangka panjang dan oleh karenanya waktu yang ditetapkan pun adakalanya hingga ratusan tahun.

g. Kearifan lokal masyarakat Krui-Lampung Barat

Repong Damar atau hutan damar, merupakan model pengelolaan lahan bekas lading dalam bentuk wanatani yang dikembangkan oleh masyarakat Krui di Lampung Barat, yaitu menanami lahan bekas lading dengan berbagai jenis tanaman, antara lain damar, kopi, karet, durian.

h. Kearifan lokal masyarakat Orang Rimba-Jambi

Hompongan merupakan hutan belukar yang melingkupi kawasan inti pemukiman Orang Rimba (di kawasan Taman Nasional Bukit Dua Belas, Jambi) yang sengaja dijaga keberadaannya yang berfungsi sebagai benteng pertahanan dari gangguan pihak luar.

i. Kearifan lokal masyarakat Dayak Iban-Kalimantan Barat Tembawai merupakan hutan rakyat yang dikembangkan oleh masyarakat Dayak Iban di Kalimantan Barat, yang didalamnya terdapat tanaman produktif, seperti durian.

j. Kearifan lokal masyarakat Maluku

Sasi merupakan aturan adat yang menjadi pedoman setiap warga masyarakat Maluku dalam mengelola lingkungan termasuk pedoman pemanfaatan sumber daya alam.

k. Kearifan lokal masyarakat Maluku

Mamancing Ikan merupakan aturan adat yaitu larangan atau boboso. Pamali Mamancing Ikab ini secara yurisdiksi terbatas pada nilai-nilai adat, dan agama, tetapi konsep property right ini terbentuk dari pranata sosial masyarakat yang telah berlangsung sejak lama dalam mengatur pemanfaatan sumberdaya pesisir dan laut.

l. Kearifan lokal masyarakat Dayak Benuaq-Kalimantan Timur

Simpuk Munan atau lembo bangkak merupakan hutan tanaman buah-buahan (agroforestry) yang dikembangkan oleh masyarakat Dayak Benuaq di Kalimantan Timur.

m. Kearifan lokal masyarakat To Bentong-Sulawesi Selatan Koko dan tattakeng sebelum mengenal pertanian padi sawah, orang To Bentong mewariskan lahan bagi keturunannya berupa kebun (Koko) dan lading yang ditinggalkan (Tattakeng). Koko adalah lahan perladangan 
yang diolah secara berpindah, sedangkan Tattakeng adalah lahan bekas perladangan yang sedang diberakan.

n. Kearifan lokal masyarakat Minahasa-Sulawesi Utara Mapalus pada masyarakat Minahasa, merupakan pranata tolong menolong yang melandasi setiap kegiatan seharihari orang Minahasa, baik dalam kegiatan pertanian, yang berhubungan dengan sekitar rumah tangga, maupun untuk kegiatan yang berkaitan dengan kepentingan umum.

o. Kearifan lokal masyarakat Bolaang Mongondow-Sulawesi Selatan

Moposad dan Moduduran merupakan pranata tolong menolong yang penting untuk menjaga keserasian lingkungan sosial.

p. Kearifan lokal masyarakat Banjar - Kalimantan Selatan Kapamalian merupakan aturan-aturan (pantangan) dalam pengelolaan lingkungan, misalnya larangan membuka hutan keramat.

q. Kearifan lokal masyarakat Sumba Timur- Nusa Tengara Timur

Gugus hutan yang disebut Pahomba, terlarang keras untuk dimasuki apalagi untuk diambil hasil hutanya. Pada hakekatnya pohon-pohon di setiap pahomba itu berfungsi sebagai pohon-pohon induk yang dapat menyebarkan benih ke padang-padang rumput yang relatif luas.Karena itu, jika api tidak menghangus matikan anakan pepohonan itu, proses perluasan hutan secara alamiah dapat berlangsung. Pepohonan di pahomba disekitar batang sungai berfungsi sebagai riparian atau tumbuhan tepain sungai yang berfungsi sebagai filter terhadap materi erosi, dan sekaligus berfungsi sebagai sempadan alamiah sungai dan untuk pelestarian air sungai.

r. Kearifan lokal masyarakat Bali

Salah satu teknologi tradisional pemakaian air secara efisien dalam pertanian dilakukan dengan cara Subak. Lewat saluran pengairan yang ada pembagian aliran berdasarkan luas areal sawah dan masa pertumbuhan padi dilakukan dengan menggunakan alat bagi yang terdiri dari batang pohon kelapa atau kayu tahan air lainnya. Kayu ini dibentuk sedemikian rupa dengan cekukan atau pahatan dengan kedalaman berbeda sehingga debit air yang mengalir di satu bagian berbeda dengan debit air yang 
mengalir di bagian lainnya. Kayu pembagi air ini dapat dipindah-pindah dan dipasang diselokan sesuai dengan keperluan, yang pengaturannya ditentukan oleh Kelihan Yeh atau petugas pengatur pembagian air.

s. Kearifan lokal masyarakat Bali

Tri Hita Karana, suatu konsep yang ada dalam kebudayaan Hindu-Bali yang berintikan keharmonisan hubungan antara Manusia-Tuhan, manusia-manusia, dan manusia-alam merupakan tiga penyebab kesejahteraan jasmani dan rohani. Ini berarti bahwa nilai keharmonisan hubungan antara manusia dengan lingkungan merupakan suatu kearifan ekologi pada masyarakat dan kebudayaan Bali.

t. Kearifan lokal masyarakat Desa Gasang-Jawa Timur Bersih Deso (bersih desa) adalah suatu acara adat dan sekaligus tradisi pelestarian lingkungan yang masih dilaksanakan masyarakat Desa Gasang sampai sekarang. Dilakukan setiap tahun pada bulan Jawa Selo (Longkang) dipilih dari hari Jumat Pahing. Masyarakat secara berkelompok membersihkan lingkungan masing-masing seperti jalan, selokan umum dan sungai. Setelah selesai melaksanakan bersih deso secara berkelompok mereka menyelenggarakan upacara semacam "sedekah bumi" dengan sajian satu buah buceng besar, satu buceng kecil, sayur tanpa bumbu lombok tanpa daging, berbagai macam hasil bumi yang biasa disebut "pala kependhem" dan "pala gumantung".

u. Kearifan lokal masyarakat Desa Bendosewu-Jawa Timur Tradisi bersih desa di Desa Bendosewu dikenal dengan wewaler yang merupakan pesan dari leluhur yang babad desa. Isi pesan adalah "jika desa sudah rejo (damai, sejahtera) maka hendaknya setiap tahun diadakan upacara bersih desa." Tradisi bersih desa disertai kegiatan kebersihan lingkungan secara serentak, yaitu membersihkan jalan-jalan, rumah-rumah, pekarangan, tempat-tempat ibadah, makam dan sebagainya. Kegiatan ini disebut pula dengan "tata gelar" atau hal yang sifatnya lahiriah. Hal yang berkaitan dengan "tata gelar" dalam bersih desa bagi masyarakat Bendosewu sudah menjadi bagian hidupnya, sehingga tidak perlu diperintah lagi. 
v. Kearifan lokal masyarakat Kasepuhan Sirnaresmi-Jawa Barat

Seren Taun memiliki banyak arti bagi masyarakat kasepuhan diantaranya adalah puncak prosesi ritual pertanian yang bermakna hubungan manusia, alam, dan pencipta-Nya. Seren Taun adalah perayaan adat pertanian kasepuhan sebagai ungkapan rasa syukur setelah mengolah lahan pertanian sengan segala hambatan dan perjuangannya untuk mendapatkan hasil yang optimal. Seren Taun adalah pesta masyarakat adat Kasepuhan sebagai ungkapan rasa gembira ketika panen datang. Seren Taun juga merupakan pertunjukan kesenian-kesenian tradisional yang ada di masyarakat Kasepuhan. Adat istiadat yang berlaku di dalam Kasepuhan ini mengatur pola kehidupan masyarakat dalam berhubungan dengan sang pencipta (Hablum minallah), hubungan antar manusia (Hablum minan naas) dan hubungan manusia dengan alam lingkungannya (Hablum minal alam).

w. Kearifan lokal masyarakat Kampung Dukuh-Jawa Barat Bentuk kearifan dalam pengelolaan SDA dan lingkungan hidup yang dikembangkan masyarakat Kasepuhan Pancer Pangawinan diwujudkan dalam penataan ruang hutan, pelestarian dan pengelolaan air, pengelolaan lahan dengan pengembangan talun. Selain itu juga diwujudkan dalam pengetahuan tradisional tentang berbagai jenis sumber daya alam, seperti padi varitas lokal. Nilaiyang menekankan pentingnya melestarikan lingkungan itu dikuatkan lewat berbagai upacara tradisional, mitos dan tabu. Menurut warga Kasepuhan, hutan digolongkan menjadi 3 jenis, yaitu: Leuweung Kolot atau Leuweung Geledegan atau hutan tua, yaitu hutan yang masih lebat ditumbuhi berbagai jenis pohon dengan kerapatan yang tinggi, dan masih banyak ditemukan binatang liar hidup di dalamnya. Hutan ini masih ada di sekitar kawasan Taman Nasional Gunung Halimun. Leuweung Titipan atau hutan keramat. Hutan ini tidak boleh dimasuki apalagi dieksploitasi oleh siapa pun, kecuali ada izin dari Abah Anom. Hutan ini akan dimasuki apabila Abah Anom menerima wangsit atau ilapat dari nenek moyang yang memerlukan sesuatu dari kawasan gunung tersebut. Kawasan hutan keramat adalah kawasan Gunung Ciwitali 
dan Gunung Girang Cibareno; Leuweung Sampalan atau Leuweung bukaan, yaitu hutan yang dapat digunakan dan dieksploitasi serta dibuka oleh warga Kasepuhan. Di sini warga boleh membuka lading, kebun sawah, menggembala ternak, mengambil kayu bakar dan hasil hutan lainnya yang ada. Yang termasuk lahan bukaan adalah lahan di sekitar tempat pemukiman penduduk. Bekas lahan lading ataupun sawah yang sudah dipanen lalu ditanami dengan tanaman musiman dan tanaman keras sehingga membentuk hutan buatan disebut Talun. Tanaman buah-buahan sering digunakan seperti duren, rambutan, atau tanaman lainnya seperti petai, cengkeh, dan sebagainya. Setelan Talun ditanami biasanya akan ditinggal begitu saja. Artinya pemeliharaannya tidak begitu intrnsif disbanding dengan kebun.

x. Kearifan lokal masyarakat Lampung

Piil Pasenggiri merupakan falsafah hidup atau pedoman dalam bertindak bagi setiap warga masyarakat Lampung, yakni: menemui muimah (ramah lingkungan), nengah nyappur (keseimbangan lingkungan), sakai sambayan (pemanfaatan lingkungan), dan juluk adek (pertumbuhan lingkungan).

y. Kearifan lokal masyarakat Lahat - Sumatera Selatan) Undang-Undang Simbur Cahaya yang sebagian substansinya mengatur tentang pentingnya pelestarian lingkungan.

z. Kearifan lokal masyarakat Sumatra Selatan

Pengetahuan Ke-Kean adalah perhitungan waktu yang tepat untuk menanam jenis tanaman tertentu yang dikaitkan dengan ilmu perbintangan.

\section{Gotong Royong Dalam Perspektif Kearifan Lokal}

Metode gotong royong merupakan salah satu alternatif pilihan yang dapat dijalankan dalam rangka upaya meningkatkan taraf pendidikan masyarakat, terutama masyarakat yang berdomisili di pedalaman. Kesulitan bersama akan akses pendidikan sudah seharusnya dijawab dengan kekompakan dan persatuan masyarakat, yakni pembangunan pendidikan berbasis swadaya masyarakat sehingga tercipta suatu lembaga pendidikan di masyarakat setempat. Metode gotong royong sebagaimana tersebut 
merupakan suatu kerja yang dilakukan secara bersama-sama dengan tertata dan teratur, semua anggota masyarakat berdiri pada kewajiban yang sama untuk tujuan bersama.

Metode gotong royong sendiri sudah lama melekat dalam kehidupan masyarakat Indonesia secara umum. keberadaan gotong royong tidak dapat dilepaskan akan adanya persamaan keperluan dan kebutuhan masyarakat yang tidak mungkin dapat diselesaikan dengan secara individualis.

Segala sesuatunya dikerjakan dengan mengandalkan kebersamaan, persatuan dan tentunya semua itu diwujudkan dalam bentuk gotong royong. Kegiatan bergotong royong sebenarnya sudah menjadi tradisi disemua daerah di Indonesia. Kegiatan ini sudah diwariskan secara turun temurun oleh nenek moyang bangsa Indonesia. Tidak ada masalah yang tidak dapat diselesaikan dengan bergotong royong. Hal ini sebagaimana kata pepatah yang mengatakan berat sama diangkat, ringan sama dijinjing. Artinya masalah seberat apapun itu tentu saja dapat diselesaikan dengan bersama-sama dan akan terasa lebih ringan. Berbanding terbalik bila segala sesuatu dijalankan dengan secara indivudualisme.

Sebagaimana analogi yang penulis gambarkan sebagai berikut, misalkan ibarat menyapu dengan sebatang lidi, tentu akan berbeda hasilnya bila dilakukan dengan seikat lidi. Sebatang lidi tidak akan mampu menyelesaikan apapun melainkan hanya sedikit dari potensinya, tetapi dengan seikat lidi ia akan lebih berguna untuk kepentingan yang lebih urgen lagi.

Menurut kamus bahasa Indonesia (2008: 498): gotong royong adalah bekerja bersama-sama (tolong-menolong, bantu membantu). Manusia adalah mahluk sosial, oleh karena itu kebersamaan, persatuan dan saling membantu merupakan kebutuhan manusia untuk tetap eksis.

Mengingat pentingnya gotong royong dalam masyarakat, Gurniwan Kamil (1987) menjelaskan secara eksplisit bahwa : Gotong royong sudah tidak dapat dipungkiri lagi sebagai ciri bangsa Indonesia yang turun temurun, sehingga keberadaannya harus dipertahankan. Pola seperti ini merupakan bentuk nyata dari solidaritas mekanik yang terdapat dalam kehidupan masyarakat, sehingga setiap warga 
yang terlibat di dalamnya memiliki hak untuk dibantu dan berkewajiban untuk membantu, dengan kata lain di dalamnya terdapat azas timbal balik.

Berdasarkan penjelasan di atas dapat dianalis bahwa setiap masyarakat memiliki hak dan kewajiban yang sama dalam kelompoknya. Dalam konteks kewajiban, setiap anggota masyarakat Memiliki kewajiban untuk bersama-sama mengerjakan sesuatu atau terlibat dalam suatu pekerjaan baik untuk kepentingan umum (bersama) maupun saling membantu diantara anggota masyarakat. Setelah turut serta mengerjakan kewajiban barulah memiliki hak untuk diperhatikan, dibantu berdasarkan ketentuan gotong royong yang berlaku dalam masyarakat tersebut.

Rochmadi (2012) menjelaskan bahwa: Gotong royong adalah bagian dari kehidupan masyarakat Indonesia, dan merupakan warisan budaya bangsa. Nilai dan perilaku gotong royong bagi masyarakat Indonesia sudah menjadi pandangan hidup, sehingga tidak bisa dipisahkan dari aktivitas kehidupannya sehari-hari. Pola hidup yang seperti ini merupakan bentuk nyata dari solidaritas mekanik yang terdapat dalam kehidupan masyarakat Indonesia. Implementasi nilai dan perilaku gotong royong pada masyarakat Indonesia merupakan bagian esensial dari revitalisasi nilai sosio budaya dan adat istiadat pada masyarakat yang memiliki budaya beragam agar terbebas dari dominasi sosial, ekonomi, politik, pertahanan dan keamanan, serta ideologi lain yang tidak mensejahterahkan 


\section{BAB 8 \\ RAGAM KEARIFAN LOKAL DI INDONESIA}

\section{A. Pengertian Kearifan Lokal}

Pengertian dari kearifan lokal yaitu nilai, gagasan, atau pandangan yang bersumber dari sebuah tempat dan didalamnya juga terdapat sifat bijaksana. Tidak hanya itu, adanya nilai-nilai yang baik yang nantinya dapat diikuti dan kemudian dipercayai oleh sejumlah masyarakat di suatu tempat serta sudah diikuti dengan cara turun temurun. Berikut ini adalah beberapa contoh dari kearifan lokal.

\section{Awig-Awig diLombok Barat dan Bali}

Awig-Awig merupakan sebuah aturan adat yang dapat dijadikan suatu pedoman agar bisa bertindak dan juga bersikap terutama didalam hal berinteraksi. Dan juga didalam hal seperti mengolah sumber daya alam dan juga lingkungannya. Dan kearifan lokal tersebut terdapat di daerah Bali dan Lombok Barat.

\section{Bebie di Sumatera Selatan}

Bebie merupakan suatu tradisi didalam menanam dan kemudian menanam padi secara bersama-sama, hal tersebut memiliki tujuan yaitu untuk agar suatu proses permanenan dapat dengan cepat terselesaikan. Apabila panennya tersebut telah selesai, maka akan adaperayaan yang menjadi suatu bentuk dari rasa syukur atas proses panen yang berhasil dan juga sukses. Kearifan lokal Bebie ini terdapat di Muara Enim, lebih tepatnya berada di Sumatera Selatan.

\section{Hutan Larang Adat di Riau}

Kearifan lokal mempunyai suatu tujuan agar masyarakat yang berada disekitarnya dapat dengan bersamasama melestarikan hutan yang berada disana. Seperti contohnya yaitu adanya suatu peraturan mengenai tak diperbolehkannya menebang hutan secara sembarangan. Apabila hal tersebut dilakukan, maka pelakunya akan dikenakan denda yaitu sebesar $100 \mathrm{~kg}$ beras ataupun bisa berbentuk uang yang jumlahnya sebesar Rp 6.000.000.

\section{Cingcowong di Jawa Barat}

Cingcowong merupakan sebuah jenis upacara yang berguna untuk meminta hujan, tradisi cingcowong ini juga 
sudah dilakukan dengan turun temurun oleh masyarakat Luragung untuk bisa melestarikan budayanya. Dan tradisi ini juga bisa menunjukkan suatu permintaan kepada Yang Maha Kuasa apabila tak ada kepatuhan di tiap perintah-Nya.

\section{Repong Damar di Lampung Barat}

Repong Damar merupakan salah satu kearifan lokal yang sering disebut juga dengan hutan damar. Repong Damar ini adalah model dari pengelolaan pada suatu lahan bekas lading didalam suatu bentuk wanatani yang kemudian dapat dikembangkan oleh masyarakat Lampung Barat di Krui. Tradisi ini menanami lahan bekas lading dengan berbagai macam jenis tanaman, contohnya yaitu seperti karet, damar, durian dan juga kopi.

\section{Tembawai di Kalimantan Barat}

Tembawai adalah sebuah hutan rakyat yang juga dikembangkan oleh rakyat Dayak Iban yang terletak di Kalimantan Barat. Didalam hutan tersebut juga memiliki berbagai jenis tumbuhan yang produktif seperti pohon durian.

\section{Pamali memancing ikan di Maluku Utara}

Pamali memancing ikan adalah suatu aturan adat yakni berupa larangan maupun boboso. Dan pamali memancing ikan ini juga secara yurisdiksi sangat terbatas kepada adat, nilai-nilai dan juga agama. Akan tetapi konsep dari property right itu terbentuk dari pranata sosial pada masyarakat yang sudah berlangsung sangat lama didalam mengatur suatu pemanfaatan sumberdaya laut dan juga pesisir. Kearifan lokal ini terdapat didaerah Desa Bobaneigo yang ada di Maluku Utara.

\section{Koko dan Tattakeng di Sulawesi Selatan}

Sebelum diperkenalkannya pertanian seperti padi sawah, rakyat To Bentong sudah mewariskan lahan untuk para keturunannya berbentuk kebun atau Koko dan juga lading yang sudah ditinggalkan atau Tattakeng. Koko merupakan suatu lahan perladangan yang bisa diolah dengan cara berpindah. Sementara Tattakeng merupakan suatu lahan bekas perladangan yang tengah diberakan. Kearifan lokal ini terletak di Minahasa provinsi Sulawesi Utara.

\section{Moposad Dan Moduduran di Sulawesi Selatan}

Moposad dan Moduduran adalah suatu pranata mengenai tolong menolong yang sangat penting untuk dapat menjaga sebuah keserasian dari lingkungan sosial. Kearifan 
lokal ini terletak di Bolaang Mongondow, provinsi Sulawesi Selatan.

\section{Pahomba di Nusa Tenggara Timur}

Pahomba atau yang biasa disebut juga dengan gugus hutan merupakan suatu tempat yang dilarang keras untuk dimasuki, terlebih lagi dengan niatan untuk mengambil hasil hutannya. Dan pada hakikatnya, pohon-pohon di tiap pahomba tersebut memiliki fungsi menjadi pohon-pohon induk yang bisa menyebarkan benih kedalam padang rumput yang cukup luas.

Oleh sebab itu, Apabila api tak menghangus dan mematikan anakan dari pepohonan tersebut, proses dari perluasan hutan yang secara alamiah bisa berlangsung. Pepohonan yang ada dipahomba dan disekitaran batang sungai memiliki fungsi menjadi suatu filter terhadap materi erosi dan juga secara sekaligus menjadi sempadan alamiah sungan yang berguna untuk pelestarian air sungai.

\section{Ke-kean di Sumatera Selatan}

Pengetahuan mengenai kekean merupakan suatu perhitungan waktu yang sesuai untuk bisa menanam berbagai jenis tumbuhan tertentu yang berkaitan dengan ilmu perbintangan.

\section{Balingkea di Sulawesi Tengah}

Balingkea adalah suatu kategori dari pandangan mengenai hutan menurut pendapat dari orang Toro. Balingkea merupakan bekas kebun yang umurnya mulai dari 6 bulan sampai dengan 1 tahun. Seringnya balingkea diolah untuk tumbuhan palawija yang berbentuk ubi kayu, jagung, rica, kacang-kacangan dan juga sayur-sayuran.

\section{Rimba Kepungan Sialang di Riau}

Para masyarakat melayu telah mengenal suatu pembagian hutan tanah yang juga terdiri atas 3 bagian, yaitu tanah perladangan, rimba larangan dan juga rimba kepungan sialang.

\section{Hompongan di Jambi}

Hompongan adalah suatu hutan belukar yang juga melingkupi suatu kawasan inti dari pemukiman Orang Rimba, atau lebih tepatnya dikawasan Taman Nasional Bukit Dua Belas di provinsi Jambi. Hal tersebut dengan sengaja dijaga ketat keberadaaannya karena memiliki fungsi menjadi suatu banteng pertahanan dari gangguan pihak dari luar. 


\section{Sasi dari Maluku}

Sasi adalah suatu adat yang menjadisuatu pedoman dari tiap warga masyarakat Maluku didalam mengelola lingkungan yang termasuk pedoman dari pemanfaatan dari sumber daya alam. 


\section{BAB 9 \\ SINERGITAS PEMBANGUNAN DI BALUTAN \\ KEARIFAN LOKAL}

\section{Kearifan Lokal}

Kearifan lokal menjadi bahan wacana dalam berbagai dimensi kehidupan manusia. Berikut ini bebrapa contoh tentang bangkitan kesadaran terhadap pentingnya kearifan lokal. Akibat industrialisasi yang terus berekspansi secara cepat, terjadilah kerusakan lingkungan. Polusi, banjir, tanah longsor dan pemanasan global (global warning) merupakan byproduct dari industrialisasi, yang bahkan sampai sekarang diyakini oleh para penganut developmentalisme sebagai satusatunya jalan menuju kemajuan dan kesejahteraan umat manusia. Pengunaan bahan bakar, konversi lahan produktif menjadi real estat dan pabrik menyebabkan kesusakan lingkungan. Eksploitasi sumber daya alam atas nama pembangunan ternyata menimbulkan penderitaan di banyak tempat. Itu semua menggambarkan bagaimana parahnya kerusakan lingkungan yang menimbulkan penderitaan masyarakat lokal akibat pembangunan yang tidak berorientasi pada kearifan lokal.

Contoh lainnya bisa dilihat dalm dimensi hubungan antarmanusia. Dalam tradisi Jawa yang sesungguhnya diwarnai oleh ajaran Islam, manusia diharuskan untuk menjalin silaturrahim. Orang bertemu muka, bercanda, berbincang-bincang dengan keakraban. Mereka memiliki waktu yang longgar untuk bercengkerama sehingga hubungan batin menjadi kuat karena bisa melihat ekspresi teman atau tetangganya. Tetapi, dalam kehidupan modern, akibat teknologi informasi, orang merasa cukup berkomunikasi dengan teknologi informasi, misalnya telepun. Manusia modern telah kehilangan sentuhan-sentuhan keakraban sesama. Tradisi gotong royong di kampung-kampung tradisional sesungguhnya merupakan instituasi untuk menguatkan keakraban dan tanggung jawab sosial. Ada nilainilai (values) yang tidak bisa digantikan oleh sistem baru, misalnya dengan urunan untuk membayar tenaga orang lain 
untuk mengerjakan tugas-tugas kolektif di suatu komunitas tertentu.

\section{Keadaban}

Menyadari pentingnya kearifan lokal. Maka tugas kita sekarang ialah menemukan kearifan lokal dan memfungsikannya untuk mengembangkan kehidupan masyarakat yang berkeadaban. Secara sederhana dapat dikatakan bahwa kehidupan masyarakat semacam itu, dalam bahasa rakyat Indonesia, adalah kehidupan yang sejahtera lahir dan batin dan berada bi bawah naungan keampunan Allah (wa rabb ghafur); juga masyarakat yang diberkahi oleh Allah (barakat min al-sama' wa al-ardl); masyarakat yang aman damai (aminan muthma'innan). Masyarakat seperti itu tidak akan lahir secara tiba-tiba, tetapi dari proses yang melibatkan usaha manusia, yang salah satunya ialah pertimbangan terhadap pentingnya kearifan lokal.

Pada masyarakat Jawa, misalnya, kearifan lokal bisa ditemukan dalam kehidupan sehari-hari baik terhadap sesama manusia, hewan, tumbuh-tumbuhan dan alam dalam pengertian yang lebih luas. Dalam hubungan manusia, kita masih menemukan budaya kewajaran (ngono yo ojo ngono), toleransi (tepo seliro), gotong royong, ketulusan, penghormatan terhadap yang lebih tua, termasuk orang tua, guru dan lain-lain. Dalam hubungan dengan hewan, kita menemukan betapa akrabnya manusia denga makhluk Allah itu, misalnya tradisi angon wedus (kambing), memelihara sapi di kandang yang dekat dengan rumah. Ini berbeda dengan ternak ayam dalam masyarakat modern yang penuh dengan kekejaman karena ingin memperbesar produksi untuk memenuhi konsumsi masyarakat modern. Dalam hubungnnannya denga alam, masyarakat masih memelihara hubungan yang akrab sehingga tidak melakukan eksploitasi sumber daya alam secara sembrono. Industrialisasi yang tidak memperhatikan kearifan lokal mengakibatkan malapetaka baik bagi masyarakat yang tinggal di sekitar maupun bagi warga dunia dalam jangka panjang.

\section{g) Budaya dan Kearifan Lokal di Era Global: Pentingnya Pendidikan Bahasa dan Seni}

Sebagai bangsa, kita memiliki kosa-budaya yang begitu melimpah ruah. Apapun bentuk dan wujudnya, budaya bangsa tersebut merupakan dan menjadi modal dan 
identitas, benteng, serta sekaligus sebagai "paspor utama," terlebih lagi, dalam tata pergaulan dan tegur-sapa global. Menjadi modal dan identitas karena dengan dan melalui budaya kita dikenal oleh dan memperkenalkan diri kepada bangsa-bangsa lain. Budaya merupakan modal dan identitas kita dalam berelasi dan berinteraksi dengan "yang lain," yang bukan kita, liyan, the others.

Pengakuan bangsa-bangsa lain atas tingginya nilainilai budaya yang kita miliki, misalnya saja, merupakan "paspor," yang melegitimasi bahwa secara kultural kita sah bergaul dan berposisi setara dengan mereka. Sementara itu, proses berelasi dan berinteraksi dengan "yang lain" itu juga meniscayakan masuknya beragam nilai secara tak terhindarkan, yang dalam sejumlah hal acapkali bertentangan dengan nilai-nilai yang sudah lama terinternalisasi dan diyakini. Dalam konteks inilah, nilainilai yang inheren dalam kosa-budaya bangsa berfungsi sebagai benteng. Akan tetapi, yang menjadi persoalan mengapa kecenderungan materialistik dan hedonik makin hari makin mengedepan di tengah kehidupan masyarakat, dan bersamaan dengannya: nilai- nilai dan karakter kebangsaan kita juga terasa kian pudar (untuk tidak mengatakan dalam proses "mulai dilupakan"), padahal kita memiliki modal dan identitas, paspor, serta benteng budaya yang kokoh. Adakah yang salah dalam mengelola sistem dan mekanisme kebudayaan dalam konteks kebangsaan kita, dan sederet pertanyaan kultural lain.

Dalam konstelasi seperti dikemukakan di atas, posisi pendidikan bahasa dan seni sebagai "proses pembudayaan" pun layak dipertanyakan: sudahkah ia menunaikan imperatif ideologis, edukatif, dan kultural sebagai fungsi-fungsi utama dalam praksisnya. Terdapat paling tidak empat alasan yang dapat dikemukakan dalam kaitan ini. Pertama, dalam keseluruhan dan keutuhannya, kebudayaan merupakan lahan dan habitat utama bagi persemaian benih-benih karakter, tempat identitas dan kepribadian tumbuh dan berkembang.

Kedua, kebudayaan memerlukan upaya pemeliharaan, pengembangan, dan pemberdayaan melalui, antara lain, pendidikan, utamanya dalam 
mencerahkan pentingnya norma/nilai, perilaku, dan benda-benda budaya kepada masyarakat. Ketiga, nilainilai luhur budaya bangsa akan menjadi sesuatu yang asing bagi masyarakat apabila praksis pendidikan bahasa dan seni dilepaskan dari bingkai dan orien $\neg$ tasi budaya. Keempat, fungsi kebudayaan sebagai sumber nilai bisa saja lama-kelamaan akan hilang apabila tidak didukung oleh masyarakat yang sadar dan terdidik. Butir-butir ini menunjukkan adanya hubungan resiprokal dan dialektis antara pendidikan bahasa dan seni di satu sisi, dan kebudayaan pada sisi yang lain: sebuah relasi yang penting bagi upaya penggalian dan pengembangan kearifan lokal dalam konteks nation and character building di era global.

h) Masuknya beragam nilai yang berasal dari "luar" (sebagai "pusat") melalui beragam piranti modern, sebagai akibat yang tak terhindarkan dari proses global, telah memberi warna dan corak tersendiri pada sendi-sendi kehidupan budaya bangsa. Derasnya arus global dari pusat ke "pinggiran" antara lain mengakibatkan munculnya situasi "ketertinggalan budaya," dan sangat mungkin, "longsor budaya." Ketertinggalan budaya melanda sebagian besar masyarakat negara berkembang (sebagai "pinggiran") dalam upayanya mencapai strata modernis bersamaan dengan membanjirnya informasi.

Simbol budaya baru, kadang-kadang, diberi makna tidak pada tempatnya. Teknologi yang berkembang begitu pesat dan canggihnya juga menyebabkan pola komunikasi masyarakat berubah dengan cepat. Pengetahuan dan pengalaman manusia dibentuk oleh berbagai informasi yang dapat disimpan dan ditransmisikan dengan kecepatan yang begitu dahsyat dan dapat menjangkau kawasan yang begitu luas. Bahasa lisan digantikan peranannya oleh citra-citra visual. Sikap utilitarian, materialis, dan hedonis mengedepan berbarengan dengan munculnya pergeseran yang terus-menerus. Akibatnya, pandangan dunia masyarakat pun pecah, tercabik, dan salah-tempat (dislokasi). Ini semua bisa diperhitungkan sebagai tantangan sekaligus ancaman bagi nilai-nilai, karakter, dan identitas bangsa. Proses persemukaan, persinggungan, dan "persetubuhan" 
budaya yang tengah dan akan terus terjadi tersebut benar-benar akan menjadi sesuatu yang membahayakan apabila di dalam sistem dan mekanisme kebudayaan dalam konteks kebangsaan tidak disediakan ruang, peluang, atau kemungkinan perubahan. Karena apa? Sesuatu akan menjadi langgeng bilamana dirinya terbuka bagi perubahan dan pembaharuan. Dalam hubungan ini, berpikir dan bertindak strategis pun menjadi penting dan mendesak. Perancangan dan pelaksanaan berbagai upaya yang muara akhirnya pada terciptanya kekenyalan identitas bangsa dalam menghadapi dan memasuki berbagai proses tersebut perlu segera dilakukan agar nilai-nilai budaya dapat dirawat selayaknya dan yang mulai pudar akan dapat dicahayakan kembali.

Ketika muncul kesadaran bahwa yang lokal selalu menjadi korban marginalisasi sehingga terpinggirkan, seluruh masyarakat (etnik) yang ada merasa perlu meredefinisi diri sendiri dan budayanya. Memasuki "kandang" budaya lokal, di satu sisi, dapat diperhitungkan sebagai dasar bagi upaya menciptakan situasi sadar budaya bangsa. Hanya saja, tindakan ini bisa saja memunculkan paradoks di sisi lainnya, yakni ketika ia ditafsirkan secara linear bahwa kita akan hidup di masa depan, bukan di masa lalu. Bahkan, ketika proses ini menjadi eksklusif, ia menjadi tantangan tersendiri karena yang tercipta bukan lagi kesadaran bersama dalam konteks nation state, melainkan semangat etnonasionalisme.

Oleh karena itu, orientasinya harus diarahkan pada kesejatian fitrah manusia sebagai pelaku yang sadar untuk bertindak mengatasi dunia dan realitas yang (mungkin bisa) memusuhi dan menindasnya, yang secara keseluruhan berada dalam bingkai kebersamaan dengan liyan ("yang lain," the other). Konsekuensinya, sistem dan mekanisme budaya lokal dan translokal tetap harus dipelihara, dikembangkan, dan diberdayakan bersama.

Persilangan dialektis antara liyan dan dorongan untuk mencipta dan mencipta ulang identitas lokal yang independen dalam suatu proses transformasi yang berkesinambungan menjadi imperatif untuk dilaksanakan. Tujuannya adalah menyiapkan sebuah habitat agar figur- 
figur yang terlibat di dalamnya mampu menghayati nilai lokal, dan sekaligus mampu membuka ruang tegur-sapa dengan liyan dalam dirinya: untuk menjadi lokal sekaligus translokal dan global. Pendek kata, agar masyarakat memiliki kekenyalan budaya yang memadai. Persoalan nilai lokal dan translokal tersebut memang memunculkan dilema: apakah nilai-nilai yang ada itu diolah secara kreatif (dalam arti didialogkan dengan nilai "yang lain") melalui rekonsiliasi yang seimbang, atau ia dimanfaatkan begitu saja sehingga terjadi homogenisasi nilai dan sekaligus dominasi atas nilai yang lain melalui melalui rekonsiliasi subordinasi.

Yang jelas, upaya apapun yang dipilih dan dilakukan hendaknya tidak terjebak menjadi upaya penghapusan melalui rekonsiliasi eliminasi. Kebijakan apapun yang diambil dan mengatasnamakan kepentingan publik, karenanya, kebijakan itu harus selalu didasarkan pada wawasan kultural. Situasi polifonik dan multikultural harus menjadi dasar utamanya. Implikasinya, habitat budaya kewargaan yang sehat harus disiapkan, yakni suatu habitat yang meniscayakan tersedianya ruang dan peluang bagi partisipasi penuh dan interaksi yang terbuka bagi semua unsur masyarakat yang beragam.

Hal tersebut penting karena mereka yang tetap menghayati nilai-nilai budaya lokalnya dikhawatirkan akan menjadi kaum marginal yang kurang dimunculkan dalam konstelasi informasi translokal dan global, dan seringkali kurang diuntungkan secara material. Oleh karena itu, upaya membangun kesadaran terhadap adanya kearifan lokal sebagai sebuah realitas budaya, yang juga berfungsi dalam memposisikan identitas budaya, bagi masyarakat tertentu sebagai pencirinya, pada akhirnya harus menjadi spirit yang tidak boleh diabaikan dalam konteks menjaga nilai-nilai kebangsaan agar tidak pudar dan agar nilai-nilai itu tetap dihayati dalam situasi apapun.

Sebagai bangsa yang bhineka, Indonesia memiliki dua macam sistem budaya yang keduanya harus dipelihara, dikembangkan, dan diberdayakan yakni sistem budaya nasional dan sistem budaya etnik lokal. Sistem 
budaya nasional adalah sesuatu yang hingga kini masih berproses terus. Sistem ini berlaku secara umum untuk seluruh bangsa Indonesia, tetapi sekaligus berada di luar ikatan budaya etnik lokal yang manapun. Nilai-nilai budaya yang terbentuk dalam sistem budaya nasional itu bersifat menyongsong masa depan.

Dalam hubungan ini, kenyataannya, nilai-nilai tersebut hakikatnya merupakan "serat-serat irisan" yang terbentuk tatkala dua atau lebih budaya etnik lokal bersemuka, bersinggungan, dan saling memperkaya atas dasar persamaan-persamaan yang ada di antaranya. Jadi, nilai-nilai budaya lokal tertentu menjadi bercitra translokal/nasional karena dipadu dengan nilai-nilai lain yang sesungguhnya diderivasikan dari nilai-nilai budaya lama yang terdapat dalam berbagai sistem budaya etnik lokal.

Kearifan-kearifan lokal pada dasarnya dapat dipandang sebagai landasan bagi pembentukan jatidiri bangsa secara translokal (nasional). Kearifan-kearifan lokal itulah yang membuat budaya bangsa memiliki akar. Budaya etnik lokal seringkali berfungsi sebagai sumber atau acuan bagi penciptaan-penciptaan baru, misalnya dalam bahasa, seni, tata masyarakat, teknologi, dan sebagainya, yang kemudian ditampilkan dalam perikehidupan lintasbudaya. Karenanya, upaya penggalian kearifan lokal pada dasarnya untuk mencari, dan akhirnya untuk menetapkan identitas bangsa, yang mungkin hilang karena proses persilangan dialektis, atau karena akulturasi dan transformasi yang telah, sedang, dan akan terus terjadi sebagai sesuatu yang tak terelakkan. Upaya menemukan identitas bangsa yang baru atas dasar kearifan lokal merupakan hal yang penting demi penyatuan budaya bangsa di atas dasar identitas daerah-daerah Nusantara. Jadi, ujung akhir situasi sadar budaya yang ingin dicapai bukanlah situasi nekrofili, yakni perasaan cinta kepada segala sesuatu yang bendawi/wujudiyah yang tidak berjiwa kehidupan, melainkan situasi biofili, yakni perasaan cinta kepada segala sesuatu yang maknawiah yang berjiwa kehidupan. Dengan cara demikian, seluruh warga bangsa diharapkan 
memiliki kekenyalan budaya yang memadai dalam menghadapi tantangan global.

i) Budaya Barat yang sudah maju secara ekonomis dan teknologis secara tak terhindarkan telah melanda kita dengan begitu kuat sehingga kita merasa kehilangan (sebagian) identitas tradisional bangsa. Munculnya keinginan untuk membangun kembali identitas bangsa, pada hakikatnya dapat dipertimbangkan sebagai salah satu sarana yang penting untuk menyeleksi, dan bukannya melawan, pengaruh budaya "lain." Gerakan nativisme bisa saja dipandang naif, akan tetapi ia merupakan suatu reaksi logis apabila diletakkan dalam perspektif budaya yang berubah sangat cepat.

Dengan selalu memperhitungkan kearifan lokal lewat dan dalam proses budaya, keniscayaan masyarakat terperangkap dalam situasi menjadi masyarakat yang terasing dari realitas dirinya, yang "menjadi ada" dalam pengertian "menjadi seperti liyan dan bukannya dirinya sendiri," dapat dihindari. Jadi, penempatan hasil upaya penggalian kearifan-kearifan lokal dalam proses budaya harus selalu dimaknai dalam konteks upaya menyiapkan masyarakat memiliki kekenyalan budaya, dan bukannya sebagai domestikasi atau penjinakkan sosial budaya. Dikatakan demikian karena upaya menggali dan menyadari kembali kearifan lokal dapat dikatakan sebagai gerakan kembali pada basis nilai budaya daerahnya sendiri sebagai bagian upaya membangun identitas, dan sebagai semacam filter dalam menyeleksi pengaruh budaya liyan.

Nilai-nilai kearifan lokal tersebut meniscayakan fungsi yang strategis bagi pembentukan karakter dan identitas, yang pada gilirannya akan memunculkan sikap budaya yang mandiri, penuh inisiatif, dan kreatif. Perawatan, pengembangan, dan pemberdayaan kearifankearifan lokal yang relevan dan kontekstual memiliki arti penting bagi berkembangannya suatu masyarakat, terutama jika dilihat dari sudut kekenyalan budaya, di samping juga mempunyai arti penting bagi identitas daerah yang bersangkutan. Karya-karya seni budaya yang menempatkan nilai-nilai lokalnya sebagai sumber inspirasi kreatif, bagi daerah yang bersangkutan akan 
mendorong munculnya sikap bangga terhadap budaya dan daerahnya. Karya-karya kreatif itu bisa saja ditampilkan dalam wajah atau wacana translokal sehingga memiliki sumbangan yang besar bagi terciptanya identitas baru bagi bangsa secara keseluruhan. Kearifan lokal, yang juga meniscayakan adanya muatan budaya masa lalu, dengan demikian, juga berfungsi untuk membangun kerinduan pada kehidupan nenek moyang, yang menjadi tonggak kehidupan masa sekarang. Anggapan bahwa yang relevan dengan kehidupan hanyalah "masa kini dan di sini" juga dapat dihindari. Kearifan lokal dapat dijadikan semacam jembatan yang menghubungkan masa lalu dan masa sekarang, generasi nenek moyang dan generasi sekarang, demi menyiapkan masa depan dan generasi mendatang. Pada gilirannya, ia pun dapat dijadikan semacam simpai perekat budaya antargenerasi, dan menghindarkan diri dari situasi ahistoris.

Dalam konteks tersebut, pemosisian pendidikan bahasa dan seni secara strategis menjadi penting. Pendekatan multikultural --yang menghindari sifat satu arah, kognitif, dan eksklusif; juga menghindari superioritas, primordialisme, dan eksklusivisme nilai tertentu-- merupakan salah satu jalan yang bisa ditempuh. Melaluinya, pemahaman nilai-nilai bersama dan upaya kolaboratif mengatasi masalah-masalah bersama diupayakan, potensi nilai yang bersifat transdicahayakan. Nilai tenggang rasa antarsesama dijadikan dasar utama, di samping keserbanekaan keyakinan, tradisi, adat, dan serat-serat budaya lainnya ditempatkan sewajar-wajarnya melalui tegur-sapa yang ramah. Semua itu dapat terlaksana apabila materi dalam proses pendidikan bahasa dan seni diperhitungkan sebagai "rumah" pengalaman kemanusiaan kita.

Dalam dan melalui proses semacam itu, kita "merumahkan" pengalaman-pengalaman kita yang tidak pernah singular. Jika butir-butir tersebut mampu kita implementasikan dalam rangka nation and character building, niscaya histeria sosial, situasi yang rentan terhadap sawan budaya, atau schizofrenia kultural, dapat dihindari. Pendidikan karakter niscaya menghindari 
terbentuknya manusia-manusia yang berwajah garang, yang wataknya dan perilakunya keras, brutal, dan agresif, yang salah satu kehendak besarnya adalah memusuhi yang lain, yang satu ingin menguasai dan menindas yang lain.

Pendidikan karakter niscaya berupaya membentuk manusia yang mampu menghargai harkat dan hak-hak azasi, dan bukannya membentuk manusia yang hanya menjadi pendusta bagi hati nurani diri mereka sendiri. Pengembangan pendidikan karakter berbasis kearifan lokal, dengan demikian, hakikatnya merupakan upaya menyiapkan dan membentuk sebuah masyarakat yang keberlangsungannya didasarkan pada prinsipprinsip moral. Untuk mewujudkannya, "angan-angan" segelintir manusia (yang kebetulan sedang "berkuasa," misalnya saja), tidak boleh mengalahkan konvensi, common sense, dan kesepakatan-kesepakatan yang sudah ada, apalagi yang sudah terwujud dalam kaidah hukum; pertumbuhan organisasi-organisasi kewargaan juga perlu disemai, bukan malah ditekan; perbedaan pendapat juga tidak boleh dibungkam. Dengan demikian, upaya pengembangan yang dilaksanakan sudah seharusnya mampu pula menemukan, menghidupkan, dan menyegarkan kembali semangat kebebasan, individualitas, kemanusiaan, dan toleransi dalam jiwa. Untuk itu, keutamaan kecendekiawanan dan pengayaan kultural merupakan keniscayaan, yaitu keniscayaan untuk menanamkan ke dalam dirinya prinsip-prinsip etika dan kebenaran moral yang berasal dari cita-cita peradaban dan warisan intelektual yang benar-benar berakar pada kultur sendiri.

j) Pengintegrasian nilai-nilai budaya dan kearifan lokal dalam proses pendidikan bahasa dan seni mengandaikan bahwa siswa/mahasiswa akan mengkonstruksikan pengetahuan atau menyemaikan benih-benih nilai positif dalam dirinya sebagai hasil "pemikiran" dan interaksinya dalam konteks sosial-budaya yang mengepung dan mengkondisikannya. Siswa/mahasiswa diharapkan mampu menciptakan makna yang saheh bagi dirinya berdasarkan interaksi antara pengetahuan yang telah dimiliki, diketahui, dan dipercayai; dengan gejala, gagasan, 
atau informasi baru yang diperoleh di dalam proses pendidikan yang ditempuhnya. Oleh karena itu, nilai-nilai budaya dan kearifan lokal yang dimaksud harus dihadirkan dalam kelas pembelajaran/perkuliahan.

Penempatan nilai-nilai kearifan lokal sebagai konteks pendidikan bahasa dan seni berpotensi mendekatkan dan menyadarkan peserta-didik terhadap lingkungan kehidupannya: dari adat istiadat dan bendabenda budaya tempat nilai-nilai itu melekat dan bersemayam di dalamnya. Dengan demikian, strategi penghadiran lingkungan budaya merupakan bagian dari proses penebaran benih dan pembumian nilai. Ketika siswa/mahasiswa berinteraksi dan beradaptasi dengan lingkungan (budaya), sesungguhnya mereka sedang berada dalam periswa belajar. Lingkungan budaya merupakan sebuah "lokus" untuk mendapatkan pengalaman (-pengalaman baru). Kearifan lokal yang diintegrasikan dalam praksis pendidikan bahasa dan seni akan menciptakan medan eksplorasi bagi siswa/mahasiswa dalam memahami dan menghayati nilai tertentu. Mereka tidak hanya ngerti, tetapi juga nglakoni dan ngrasakke, berinteraksi dengannya melalui beragam proses: knowing, doing, dan being pun terintegrasi.

Ketika hasil penggalian dan pengembangan nilainilai budaya dan kearifan lokal ditautkan dengan, dan diintegrasikan dalam pendidikan bahasa dan seni, terdapat tiga alternatif yang dimungkinkan. Pertama, pendidikan tentang nilai-nilai budaya dan kearifan lokal tertentu. Alternatif ini menempatkan nilai-nilai budaya dan kearifan lokal sebagai subjek dan objek kajian. Nilainilai budaya dan kearifan lokal tertentu dipelajari dalam satu program studi khusus: tentang budaya dan untuk budaya. Dalam hal ini, nilai-nilai budaya dan kearifan lokal tidak terintegrasi dengan disiplin keilmuan lain. Kedua, pendidikan dengan nilai-nilai budaya dan kearifan lokal terjadi pada saat nilai-nilai budaya dan kearifan lokal tertentu diperkenalkan kepada siswa/mahasiswa sebagai cara atau metode untuk mempelajari suatu konsep tertentu. Belajar dengan nilai-nilai budaya dan kearifan lokal meliputi pemanfaatan beragam hal yang inheren di dalamnya: menjadi media pembelajaran dalam proses 
belajar, menjadi konteks dari contoh-contoh tentang konsep atau prinsip, serta menjadi konteks penerapan prinsip atau prosedur tertentu. Ketiga, pendidikan melalui nilai-nilai budaya dan kearifan lokal merupakan strategi yang memberikan kesempatan kepada siswa/mahasiswa untuk menunjukkan pencapaian pemahaman atau makna yang diciptakannya melalui beragam perwujudan budaya yang berbasis nilai-nilai budaya dan kearifan lokal tertentu. "Produk-produk" budaya yang diwujudkan siswa/mahasiswa, misalnya saja poster, karangan, lukisan, lagu, ataupun puisi yang bertema nilai-nilai budaya dan kearifan lokal tertentu, dapat diperhitungkan untuk melihat seberapa jauh peserta-didik memperoleh pemahaman proses tertentu, dan seberapa besar kreativitasnya dalam rangka pencapaian kompetensi tertentu.

k) Akhirnya, ketika etnisitas dipahami sebagai sebuah konsep kultural yang berpusat pada pembagian normanorma, nilai-nilai, kepercayaan, simbol, dan praktikpraktik kultural, maka kearifan lokal sesungguhnya menjadi sarana yang utama dalam mengikat keutuhan etinisitas itu. Oleh karena itu, ketika kearifan lokal diintegrasikan dalam praksis pendidikan bahasa dan seni, model-model pembelajaran yang dipilih dan dikembangkan perlu dilakukan secara cermat. Dalam hubungan ini, paling tidak terdapat 6 (enam) model yang perlu dicermati, yakni model pohon, model kristal, model sangkar burung, model jamur, model amuba, dan model DNA.

Dalam "model pohon," akar proses pengembangan yang dilakukan berada dalam nilai-nilai lokal dan tradisi, tetapi menyerap sumber-sumber eksternal yang relevan dan berguna untuk tumbuh keluar. Dalam kaitan ini, pengembangan pembelajaran kearifan lokal dalam konstelasi pendidikan translokal (nasional) dan global tetap mengedepankan, karena memerlukan, akar-akar budaya lokal. Tujuan utamanya adalah menyiapkan pribadi lokal yang berwawasan internasional, yakni individu yang utamanya bertindak pada tataran lokal, tetap ia/mereka berkembang secara global. 
Dengan demikian, pengembangan kurikulum pembelajaran kearifan lokal harus didasarkan pada nilainilai dan aset budaya lokal itu sendiri, tetapi sekaligus menyerap teknologi dan wawasan global yang cocok untuk mendukung pengembangan komunitas berikut individu-individunya sebagai warga lokal. Model ini diharapkan mampu mendorong komunitas lokal untuk memelihara nilai-nilai tradisional, identitas kultural, dan akumulasi pengetahuan lokalnya karena tumbuh, berkembang, dan berinteraksi dengan asupan energi dari sumber-sumber eksternal. Pertumbuhan komunitas lokal yang berhasil akan memberikan kontribusi pada pertumbuhan komunitas dan pengetahuan global.

Akan tetapi, jika akar kulturalnya sempit dan miskin, pertumbuhan komunitas dan individu lokal akan menjadi begitu terikat dan menyakitkan. Untuk menghindari hal itu, juga untuk menghindari jebakan pertumbuhan dan perkembangan yang hanya bersifat teknis jangka pendek, dinamisasi kultural harus dilakukan juga secara berbarengan. Dengan cara demikian, pengetahuan global yang dikonversikan ke dalam pengetahuan lokal tidak terbatas pada bias kultural, yang seringkali berkedok sikap "selektif."

Kunci proses pengembangan "model kristal" terletak pada kesadaran bahwa pemekaran kearifan lokal berfungsi untuk mengkristalisasikan dan mengakumulasi pengetahuan eksternal (translokal dan global) yang cocok dengan bentuk-bentuk yang sudah ada. Dalam kaitan ini, pengembangan lebih diarahkan untuk mengakumulasi pengetahuan eksternal yang ada di sekitar yang lokal.

Implikasinya, desain kurikulum dan pembelajaran diorientasikan untuk mengidentifikasi kebutuhan dan nilai-nilai kelokalan yang paling mendasar sebagai landasan fundamental untuk mengakumulasi sumbersumber pengetahuan eksternal yang relevan dan signifikan bagi pendidikan sebagai proses pembudayaan. Yang pertama dan utama adalah pemahaman terhadap struktur pengetahuan kelokalan sebagai dasar ketika pengetahuan dan kearifan yang bersifat eksternal diakumulasi. Model ini diharapkan mampu menyiapkan manusia lokal yang memiliki sejumlah pengetahuan 
global, yakni pribadi-pribadi yang mampu berpikir dan bertindak lokal dengan memunculkan teknik-teknik global. Dalam model ini, konflik antara kebutuhan lokal dan pengetahuan global yang diserap dan diakumulasi dalam pengembangan komunitas dan individu lokal, dapat diminimalkan.

Karena, asupan global hal-hal yang dikehendaki dan yang tidak dikehendaki lebih mudah untuk diidentifikasi. Eksternalisasi yang berlebihan juga lebih mudah dikendalikan. Hanya saja, tidak mudah untuk mendapat seperangkat nilai atau hasil-hasil lokal yang baik yang dapat digunakan untuk mengkristalisasikan dan melokalisasikan pengetahuan dan kearifan lokal yang berdaya guna dan membuahkan hasil secara penuh. Tipetipe dan hakikat yang asli lokal itu sendiri bisa saja hanya mengkristalkan hal-hal sama saja dengan yang sudah ada.।

Proses pengembangan "model sangkar burung" terbuka bagi kehadiran sumber-sumber dan pengetahuan global, tetapi membatasi perkembangan lokal dan interaksi yang bersifat eksternal untuk menetapkan suatu kerangka kerja. Pengembangan pembelajaran kearifan lokal sebagai bagian dari budaya lokal dalam keseluruhannya dalam konstelasi yang lebih luas memerlukan kerangka kerja lokal yang berfungsi protektif dan selektif. Dalam kaitan ini, desain kurikulum hendaknya memiliki kerangka kerja lokal dengan batas-batas ideologis dan norma-norma sosial yang jelas. Harapannya, semua aktivitas edukasional memiliki fokus lokal yang jelas ketika bersemuka dengan pengetahuan dan masukan global. Perhatian dan kesetiaan lokal hendaknya menjadi bagian utama pendidikan.

Model ini diharapkan mampu menyiapkan manusia lokal dengan wawasan global yang terbatasi, yakni pribadi-pribadi yang bertindak lokal dengan pengetahuan global yang sudah disaring. Kerangka kerja yang disiapkan diharapkan mampu menjamin relevansi lokal, membantu menghindari hilangnya identitas lokal, dan memproteksi interes lokal dari globalisasi yang berlebihan. Hanya saja, penetapan batas-batas sosial dan 
kultural yang tepat untuk menyaring dampak global dan untuk menjamin relevansi lokal bukan hal yang mudah dilakukan. Karena, batas-batas tersebut bisa saja terlampau ketat dan tertutup, sehingga interaksi penting dengan dunia luar menjadi terkendala, di samping pertumbuhan pengetahuan lokal juga cenderung terhambat.

Dalam prosesnya, "model DNA" mengidentifikasi dan mencangkok elemen-elemen kunci yang lebih baik yang berasal dari pengetahuan global untuk menggantikan komponen-komponen lokal yang sudah tidak lagi berdaya dalam rangka pengembangan. Implikasinya, desain kurikulum hendaknya sangat selektif, baik terhadap pengetahuan lokal maupun global.Tujuannya untuk memilih elemen-elemen yang terbaik dari keduanya. Pemahaman terhadap kelemahan dan kekuatan elemen, baik pengetahun lokal maupun global, merupakan hal yang penting dalam rangka menumbuhkan sikap terbuka bagi pencangkokan elemenelemen apapun yang baik dalam konteks lokal.

Cara ini diharapkan mampu menyiapkan manusia dengan elemen campuran antara yang lokal dan global, yakni pribadi-pribadi yang mampu bertindak dan berpikir dengan pengetahuan campuran lokal dan global. Dalam model ini, investigasi rasional dan transplantasi elemen dan pengetahuan yang valid terbuka lebar hampir tanpa kendala lokal dan kultural. Dalam rangka mempelajari dan memperbaiki perkembangan dan pratik-praktik lokal, model ini lebih efisien. Akan tetapi, identifikasi terhadap kelemahan dan kekuatan elemen-elemen tertentu belum tentu benar, baik secara kultural maupun sosial.

Di samping itu, asumsi yang menyatakan pencangkokan dan penggantian dapat dilakukan dengan mudah tanpa resistensi kultural dan tanpa dampak sosial yang negatif terhadap perkembangan individu dan komunitas lokal, merupakan asumsi yang terlampau mekanistik. Yang diutamakan dalam "model jamur" adalah proses pencernaan tipe-tipe pengetahuan global sebagai nutrisi bagi individu dan perkembangan lokal.

Artinya, pengetahuan lokal berfungsi untuk mencerna sejumlah pengetahuan global dan 
mengkonversikannya menjadi nutrisi lokal demi pengembangan individu dan komunitas lokal. Implikasinya, kurikulum dan pembelajaran diarahkan pada kemampuan mengidentifikasi dan mempelajari apakah pengetahuan global itu bernilai dan penting. Aktivitas pendidikan didesain untuk mencerna pengetahuan global yang kompleks ke dalam bentukbentuk yang tepat sehinggai dapat disuap oleh individuindividu lokal demi pertumbuhan yang diperlukan.

Model ini diharapkan mampu menyiapkan manusia yang dilengkapi dengan tipe pengetahuan global tertentu, yakni pribadi-pribadi yang dalam hal bertindak dan berpikir bergantung pada pengetahuan global yang relevan. Dalam model ini, pencernaan dan penyerapan elemen-elemen pengetahuan global yang berguna lebih mudah disiapkan daripada menghasilkan pengetahuan lokal dari awal. Akar demi pertumbuhan dan pengembangan didasarkan pada pengetahuan global sebagai alternatif nilai-nilai atau budaya lokal. Akan tetapi, model ini mengutamakan proses pencernaan dan penyerapan satu-arah terhadap pengetahuan eksternal.

Dalam prosesnya, "model amuba" membuat pengetahuan global benar-benar berguna dengan hambatan lokal yang paling minimal. Artinya, pengetahuan lokal difungsikan untuk mendayagunakan dan mengakumulasi secara maksimal pengetahuan global dalam konteks lokal. Implikasinya, kurikulum hendaknya memasukkan rentangan pengetahuan dan perspektif global secara penuh. Hambatan kultural dan nilai-nilai lokal dapat diminimalkan dalam desain kurikulum dan pembelajaran agar sikap terbuka secara total terhadap pembelajaran global dapat ditumbuhkan. Model ini diharapkan mampu menyiapkan manusia yang terbuka dan flkesibel tanpa identitas lokal apapun, yakni bertindak dan berpikir global dan cair. Kekuatan model ini terletak pada keterbukaan dan fleksibilitasnya terhadap seluruh eksposur global.

Dalam mengakumulasi sumber-sumber dan pengetahuan global, hambatan lokal dan kultural sedikit, sehingga perkembangan individu dan komunitas lokal memiliki kesempatan menguntungkan yang lebih luas. 
Akan tetapi, model ini berpotensi menghilangkan nilainilai lokal dan identitas kultural. Sangat dimungkinkan komunitas lokal akan kehilangan panduan dan solidaritas sosial sepanjang proses globaliasasi.

l) Keenam model pengembangan yang dikemukakan di atas dapat dijadikan alternatif pengembangan pembelajaran kearifan lokal. Pilihan terhadapnya lebih ditentukan arah orientasi pembelajaran kearifan lokal sebagai bagian penting budaya lokal dalam keseluruhannya.

Berdasarkan luasnya dependensi pengetahuan global dan orientasi nilai dan kultur lokal, tampak bahwa model amuba dan jamur kurang relevan dan kurang signifikan karena dependensi globalnya sangat kuat. Model pohon, kristal, dan sangkar burung memiliki orientasi lokal lebih kuat, sedangkan model DNA terletak di antara dua kelompok tersebut. Dengan demikian, terdapat dua orientasi utama. Pertama, orientasi pengembangan pembelajaran kearifan lokal bisa saja secara total menolak pengetahuan dan keterlibatan global, tetapi secara kuat menekankan relevansi dan keterlibatan komunitas lokal dalam merancang dan melaksanakan pendidikan.

Nilai-nilai lokal yang ada, identitas kultural, pegalaman komunitas, dan pengetahuan lokal merupakan bagian-bagian inti pendidikan. Kedua, orientasinya adalah pendidikan yang terikat oleh tempat secara tradisional, yang diisolasikan dari komunitas lokal dan jagat luar. Tujuan pendidikan, isi kurikulum, dan praktik pedagogis dipelihara agar tidak berubah untuk kurun waktu yang lama dan sangat kecil relevansinya dengan pengalaman komunitas keseharian. Terdapat kesenjangan besar antara pendidikan yang diberikan dengan realitas global dan lokal.

Dua titik ekstrem tersebut niscaya tidak menguntungkan ketika pembelajaran kearifan lokal diperhitungkan sebagai komponen strategis kebudayaan dalam fungsi ideologis, pedagogis, dan kulturalnya.

Perkembangan individu dan komunitas lokal sering kehilangan tradisionalitasnya ini pada saat berhadapan dengan tantangan serius dalam era baru transformasi dan globalisasi. Oleh karena itu, ke depan, 
pengembangan hendaknya diorientasikan pelokalan dan pengglobalan sekaligus. Ini merupakan skenario yang ideal, yang menekankan baik lokalisasi mapun globalisasi dalam pendidikan bahasa dan seni. Pengintegrasian keduanya dapat dilakukan melalui model pohon, kristal, sangkar burung, dan DNA. Skenario ini bertujuan melokalkan pengetahuan dan sumber-sumber global dan membuatnya valid dan relevan dengan konteks lokal.

Di samping itu juga bertujuan untuk mengglobalkan kesempatan dan pengalaman edukasional bagi para siswa dan meluaskan wawasan internasional mereka. Apabila orientasi pengembangan pembelajaran kearifan lokal diarahkan pada lokalisasi dan globalisasi sekaligus, konsepsi belajar dan pembelajaran tentang, melalui, dan dengan kearifan lokal menjadi penting untuk dipertimbangkan dalam praktik pelaksanaannya.

Proses pembelajaran yang cenderung menekankan pencapaian kurikulum dan penyampaian materi secara tekstual semata harus segera ditinggalkan dan diganti dengan pengembangan kemampuan belajar, kreativitas, dan logika berpikir siswa. Situasi dan posisi siswa/mahasiswa sebagai penerima pasif semua informasi yang disampaikan guru/dosen, juga harus segera didinamisasikan sehingga dominasi guru/dosen, ketergantungan pada pada buku teks, dan kebenaran tunggal dalam proses pembelajaran sedikit demi sedikit dapat ditinggalkan. Dalam kaitan ini, pembelajaran bermakna harus diciptakan dan dirancang secara kreatif, sehingga memungkinkan terjadi interaksi dan negosiasi untuk penciptaan arti dan konstruksi makna dalam diri setiap siswa/mahasiswa dan guru/dosen, termasuk pemanfaatan kearifan lokal sebagai budaya lokal dalam pembelajaran. Hal ini penting untuk diperhitungkan karena secara konstruktivistik, siswa mengkonstruksikan pengetahuan atau menciptakan makna sebagai hasil dari pemikiran dan interaksinya dalam suatu konteks sosial. Bukankah setiap individu menciptakan makna dan pengertian baru, berdasarkan interaksi antara apa yang telah dimiliki, diketahui, dan dipercayai, dengan fenomena, ide, atau informasi baru yang dipelajari. 
Karena kearifan lokal juga merupakan "rumah pengalaman kemanusiaan," keterlibatan dan "persinggahan" siswa/mahasiswa dengannya dalam pembelajaran memungkinkan mereka belajar lebih banyak dari apa yang seharusnya. Dengan cara demikian, siswa/mahasiswa pun belajar tentang budaya komunitasnya - termasuk miskonsepsi yang inheren dalam budaya tersebut. Persentuhan siswa/mahasiswa dengan beragam bentuk budaya dalam proses pembelajaran sekaligus berarti terbukanya ruang dan peluang bagi mereka untuk secara bebas menggali prinsip-prinsip "keilmuan" berdasarkan konteks yang sudah dikenalnya, menemukan hal-hal yang bermakna di sekelilingnya (dalam komunitas budayanya), dan mendorongnya untuk membuka dan menemukan hal-hal yang baru. Pada akhirnya, mereka pun diharapkan mampu menjadi pribadi-pribadi yang berkarakter, yang memiliki kedaultan penuh atas dirinya.

\section{A. Ragam Kearifan Lokal Di Indonesia}

\section{Pengertian Kearifan Lokal}

Pengertian dari kearifan lokal yaitu nilai, gagasan, atau pandangan yang bersumber dari sebuah tempat dan didalamnya juga terdapat sifat bijaksana. Tidak hanya itu, adanya nilai-nilai yang baik yang nantinya dapat diikuti dan kemudian dipercayai oleh sejumlah masyarakat di suatu tempat serta sudah diikuti dengan cara turun temurun. Berikut ini adalah beberapa contoh dari kearifan lokal.

\section{a) Awig-Awig diLombok Barat dan Bali}

Awig-Awig merupakan sebuah aturan adat yang dapat dijadikan suatu pedoman agar bisa bertindak dan juga bersikap terutama didalam hal berinteraksi. Dan juga didalam hal seperti mengolah sumber daya alam dan juga lingkungannya. Dan kearifan lokal tersebut terdapat di daerah Bali dan Lombok Barat.

\section{b) Bebie di Sumatera Selatan}

Bebie merupakan suatu tradisi didalam menanam dan kemudian menanam padi secara bersama-sama, hal tersebut memiliki tujuan yaitu untuk agar suatu proses permanenan dapat dengan cepat terselesaikan. Apabila panennya tersebut telah selesai, maka akan adaperayaan yang menjadi suatu 
bentuk dari rasa syukur atas proses panen yang berhasil dan juga sukses. Kearifan lokal Bebie ini terdapat di Muara Enim, lebih tepatnya berada di Sumatera Selatan.

\section{c) Hutan Larang Adat di Riau}

Kearifan lokal mempunyai suatu tujuan agar masyarakat yang berada disekitarnya dapat dengan bersamasama melestarikan hutan yang berada disana. Seperti contohnya yaitu adanya suatu peraturan mengenai tak diperbolehkannya menebang hutan secara sembarangan. Apabila hal tersebut dilakukan, maka pelakunya akan dikenakan denda yaitu sebesar $100 \mathrm{~kg}$ beras ataupun bisa berbentuk uang yang jumlahnya sebesar Rp 6.000.000.

\section{d) Cingcowong di Jawa Barat}

Cingcowong merupakan sebuah jenis upacara yang berguna untuk meminta hujan, tradisi cingcowong ini juga sudah dilakukan dengan turun temurun oleh masyarakat Luragung untuk bisa melestarikan budayanya. Dan tradisi ini juga bisa menunjukkan suatu permintaan kepada Yang Maha Kuasa apabila tak ada kepatuhan di tiap perintah-Nya.

\section{e) Repong Damar di Lampung Barat}

Repong Damar merupakan salah satu kearifan lokal yang sering disebut juga dengan hutan damar. Repong Damar ini adalah model dari pengelolaan pada suatu lahan bekas lading didalam suatu bentuk wanatani yang kemudian dapat dikembangkan oleh masyarakat Lampung Barat di Krui. Tradisi ini menanami lahan bekas lading dengan berbagai macam jenis tanaman, contohnya yaitu seperti karet, damar, durian dan juga kopi.

\section{f) Tembawai di Kalimantan Barat}

Tembawai adalah sebuah hutan rakyat yang juga dikembangkan oleh rakyat Dayak Iban yang terletak di Kalimantan Barat. Didalam hutan tersebut juga memiliki berbagai jenis tumbuhan yang produktif seperti pohon durian.

\section{g) Pamali memancing ikan di Maluku Utara}

Pamali memancing ikan adalah suatu aturan adat yakni berupa larangan maupun boboso. Dan pamali memancing ikan ini juga secara yurisdiksi sangat terbatas kepada adat, nilai-nilai dan juga agama. Akan tetapi konsep dari property right itu terbentuk dari pranata sosial pada masyarakat yang sudah berlangsung sangat lama didalam mengatur suatu pemanfaatan sumberdaya laut dan juga 
pesisir. Kearifan lokal ini terdapat didaerah Desa Bobaneigo yang ada di Maluku Utara.

\section{h) Koko dan Tattakeng di Sulawesi Selatan}

Sebelum diperkenalkannya pertanian seperti padi sawah, rakyat To Bentong sudah mewariskan lahan untuk para keturunannya berbentuk kebun atau Koko dan juga lading yang sudah ditinggalkan atau Tattakeng. Koko merupakan suatu lahan perladangan yang bisa diolah dengan cara berpindah. Sementara Tattakeng merupakan suatu lahan bekas perladangan yang tengah diberakan. Kearifan lokal ini terletak di Minahasa provinsi Sulawesi Utara.

\section{i) Moposad Dan Moduduran di Sulawesi Selatan}

Moposad dan Moduduran adalah suatu pranata mengenai tolong menolong yang sangat penting untuk dapat menjaga sebuah keserasian dari lingkungan sosial. Kearifan lokal ini terletak di Bolaang Mongondow, provinsi Sulawesi Selatan.

\section{j) Pahomba di Nusa Tenggara Timur}

Pahomba atau yang biasa disebut juga dengan gugus hutan merupakan suatu tempat yang dilarang keras untuk dimasuki, terlebih lagi dengan niatan untuk mengambil hasil hutannya. Dan pada hakikatnya, pohon-pohon di tiap pahomba tersebut memiliki fungsi menjadi pohon-pohon induk yang bisa menyebarkan benih kedalam padang rumput yang cukup luas.

Oleh sebab itu, Apabila api tak menghangus dan mematikan anakan dari pepohonan tersebut, proses dari perluasan hutan yang secara alamiah bisa berlangsung. Pepohonan yang ada dipahomba dan disekitaran batang sungai memiliki fungsi menjadi suatu filter terhadap materi erosi dan juga secara sekaligus menjadi sempadan alamiah sungan yang berguna untuk pelestarian air sungai.

\section{k) Ke-kean di Sumatera Selatan}

Pengetahuan mengenai kekean merupakan suatu perhitungan waktu yang sesuai untuk bisa menanam berbagai jenis tumbuhan tertentu yang berkaitan dengan ilmu perbintangan.

\section{l) Balingkea di Sulawesi Tengah}

Balingkea adalah suatu kategori dari pandangan mengenai hutan menurut pendapat dari orang Toro. Balingkea merupakan bekas kebun yang umurnya mulai dari 
6 bulan sampai dengan 1 tahun. Seringnya balingkea diolah untuk tumbuhan palawija yang berbentuk ubi kayu, jagung, rica, kacang-kacangan dan juga sayur-sayuran.

\section{m) Rimba Kepungan Sialang di Riau}

Para masyarakat melayu telah mengenal suatu pembagian hutan tanah yang juga terdiri atas 3 bagian, yaitu tanah perladangan, rimba larangan dan juga rimba kepungan sialang.

\section{n) Hompongan di Jambi}

Hompongan adalah suatu hutan belukar yang juga melingkupi suatu kawasan inti dari pemukiman Orang Rimba, atau lebih tepatnya dikawasan Taman Nasional Bukit Dua Belas di provinsi Jambi. Hal tersebut dengan sengaja dijaga ketat keberadaaannya karena memiliki fungsi menjadi suatu banteng pertahanan dari gangguan pihak dari luar.

\section{o) Sasi dari Maluku}

Sasi adalah suatu adat yang menjadisuatu pedoman dari tiap warga masyarakat Maluku didalam mengelola lingkungan yang termasuk pedoman dari pemanfaatan dari sumber daya alam.

\section{B. Manfaat Kearifan Lokal Dalam Konteks Pembangunan Di Indonesia}

\section{Kearifan Lokal}

Kearifan lokal dapat didefinisikan sebagai suatu kekayaan budaya lokal yang mengandung kebijakan hidup; pandangan hidup (way of life) yang mengakomodasi kebijakan (wisdom) dan kearifan hidup. Di Indonesia-yang kita kenal sebagai Nusantara-kearifan lokal itu tidak hanya berlaku secara lokal pada budaya atau etnik tertentu, tetapi dapat dikatakan bersifat lintas budaya atau lintas etnik sehingga membentuk nilai budaya yang bersifat nasional. Sebagai contoh, hampir di setiap budaya lokal di Nusantara dikenal kearifan lokal yang mengajarkan gotong royong, toleransi, etos kerja, dan seterusnya. Pada umumnya etika dan nilai moral yang terkandung dalam kearifan lokal diajarkan turuntemurun, diwariskan dari generasi ke generasi melalui sastra lisan (antara lain dalam bentuk pepatah dan peribahasa, folklore), dan manuskrip.

Walaupun ada upaya pewarisan kearifan lokal dari generasi ke generasi, tidak ada jaminan bahwa kearifan lokal 
akan tetap kukuh menghadapi globalisasi yang menawarkan gaya hidup yang makin pragmatis dan konsumtif. Secara faktual dapat kita saksikan bagaimana kearifan lokal yang sarat kebijakan dan filosofi hidup nyaris tidak terimplementasikan dalam praktik hidup yang makin pragmatis. Korupsi yang merajalela hampir di semua level adalah bukti nyata pengingkaran terhadap kearifan lokal yang mengajarkan "bersakit-sakit dahulu, bersenang-senang kemudian"; "hemat pangkal kaya".

\section{Kearifan Lokal sebagai Identitas dan Ideologi Bangsa}

Boni Hargens (2011) dalam tulisannya di Kompas menyatakan bahwa arus modernisasi, liberalisasi, dan globalisasi semestinya tidak meniadakan suatu negara jatuh dalam percaturan global asal saja negara tersebut ditopang oleh identitas nasional yang kuat, tetapi juga didukung oleh ideologi dan kepemimpinan politik yang kuat.

Selain etika moral yang bersumber pada agama, di Indonesia juga terdapat kearifan lokal yang menuntun masyarakat kedalam hal pencapaian kemajuan dan keunggulan, etos kerja, serta keseimbangan dan keharmonisan alam dan sosial. Kita mengenal pepatah "gantungkan cita-citamu setinggi bintang di langit", "bersakitsakit dahulu bersenang-senang kemudian" yang mengimplikasikan ajakan untuk membangun etos kerja dan semangat untuk meraih keunggulan. Dalam hal keharmonisan sosial dan alam, hampir semua budaya di Indonesia mengenal prinsip gotong royong dan toleransi. Dalam suku tertentu yang bermukim di pedalaman juga dikenal kearifan lokal yang bersifat menjaga dan melestarikan alam sehingga alam (misalnya kayu di hutan) hanya dimanfaatkan seperlunya, tidak dikuras habis.

Dengan sumber daya alam yang melimpah dan sumber daya manusia yang banyak, semestinya Indonesia telah menjadi negara besar yang maju. Namun, di tingkat Asia Tenggara saja posisi kita di bawah Singapura yang miskin sumber daya alam dengan luas wilayah lebih kurang hanya seluas Jakarta. Sumber daya alam yang melimpah di negeri ini kadang-kadang juga tidak menjadi berkah. Gas alam diekspor ke luar negeri dengan harga jual yang lebih rendah daripada harga jual untuk pasar dalam negeri. Hutan dieksploitasi secara luar biasa untuk mengejar perolehan devisa yang pada 
akhirnya hanya mendatangkan kerusakan ekosistem alam yang disusul dengan bencana (banjir;longsor).

Kebijakan ekonomi pemerintah acap kali hanya berpihak pada kepentingan pemodal kuat. Padahal, Pasal 33 Undang-Undang Dasar 1945-yang oleh para pendiri republik ini diciptakan untuk mengakomodasi kearifan lokal yang ada di negeri ini (seperti gotong royong dan kekeluargaan)dengan tegas mengamanatkan bahwa perekonomian nasional disusun berdasarkan asas kekeluargaan dan sumber daya alam yang ada dikuasai negara untuk kemakmuran rakyat. Secara faktual, dapat kita saksikan pertumbuhan mini market yang sangat subur yang mematikan warung rumah tangga.

Sementara itu, dalam masyarakat sendiri sering terjadi tindak kekerasan yang mereduksi nilai toleransi. Dalam konteks perubahan nilai sosiokultural juga terjadi pergeseran orientasi nilai. Masyarakat cenderung makin pragmatis dan makin berorientasi pada budaya uang serta terperangkap dalam gaya hidup konsumtif yang disodorkan kekuatan global kapitalisme.

Dalam realitas Indonesia kini, secara ekstrem dapat dikatakan bahwa kearifan lokal yang kita miliki mirip benda pusaka, yang kita warisi dari leluhur, kita simpan dan kita pelihara, tetapi kita tidak mampu mengimplementasikannya dalam kehidupan nyata sehingga pusaka tersebut sia-sia merespons tantangan zaman yang telah berubah.

Dalam kaitannya dengan kearifan lokal dan realitas Indonesia kini, Kompas edisi 20 April 2011 menampilkan dua tulisan yang relevan, yakni "Saya Mohon Ampun" oleh Radhar Panca Dahana dan "Pembangunan Gerus Kearifan Lokal” oleh Wasisto Raharjo Jati. Dalam tulisannya, Radhar Panca Dahana mencemaskan perilaku para elit negeri ini yang antara sadar dan tidak sadar telah menjadi agen kepentingan dan keserakahan ekonomi dan politik negara maju (sehingga Indonesia hanya dijadikan sekadar pasar sambil dikuras habis sumber daya alamnya). Sementara itu, Wasisto Raharjo Jati mengemukakan bahwa pembangunan di Indonesia yang terpaku pada pertumbuhan ekonomi semata telah mengabaikan kearifan lokal dan menimbulkan potensi konflik vertikal dan horizontal di kemudian hari. Karena berorientasi pada pertumbuhan ekonomi, secara tidak langsung pemerintah juga telah menjejalkan "budaya uang" sehingga 
cenderung mengurangi dan meniadakan kearifan dan budaya lokal.

Kearifan lokal dapat dipandang sebagai identitas bangsa, terlebih dalam konteks Indonesia yang memungkinkan kearifan lokal bertransformasi secara lintas budaya yang pada akhirnya melahirkan nilai budaya nasional. Di Indonesia, kearifan lokal adalah filosofi dan pandangan hidup yang mewujud dalam berbagai bidang kehidupan (tata nilai sosial dan ekonomi, arsitektur, kesehatan, tata lingkungan, dan sebagainya). Sekadar contoh, kearifan lokal yang bertumpu pada keselarasan alam telah menghasilkan pendopo dalam arsitektur Jawa. Pendopo dengan konsep ruang terbuka menjamin ventilasi dan sirkulasi udara yang lancar tanpa perlu penyejuk udara.

Pendopo adalah salah satu contoh bagaimana kearifan lokal warisan masa lampau telah memberikan kepada kita konsep arsitektur yang lega, nyaman, dan hemat energi. Sekarang ini, kita mempersoalkan krisis energi dan menyerukan hemat energi. Namun, gedung dan rumah dibangun dengan konsep bangunan tertutup sehingga memerlukan penyejuk udara yang boros energi.

Kearifan lokal dalam wujud gotong royong juga kita kenal di warung rakyat (misalnya warteg). Di warung tersebut dipraktikkan penggiliran pengelolaan warung sebagai implementasi nilai gotong royong dalam tata sosial dan ekonomi: memberi peluang kerja dan peluang mencari nafkah bagi kerabat dan warga sekampung; itu adalah salah satu kearifan lokal warisan masa lampau yang masih diberlakukan oleh sebagian masyarakat.

Di negeri ini, ada sesuatu yang aneh dan janggal: kearifan lokal di tingkat akar rumput acap kali berhadapan dengan kebijakan pemerintah yang pro pertumbuhan ekonomi (sehingga mengundang investor asing dan memberikan banyak kemudahan, termasuk dalam hal regulasi, sambil mengabaikan kearifan lokal yang tumbuh di akar rumput (Radhar Panca Dahana dan Wasisto Raharjo Jati, 2011).

Pancasila sebagai ideologi negara pada dasarnya telah mengakomodasi kearifan lokal yang hidup di Nusantara (antara lain nilai gotong royong sehingga salah satu sila Pancasila adalah "keadilan sosial bagi seluruh rakyat 
Indonesia"). UUD 1945 (yang dijiwai oleh Pancasila) juga mengamanatkan hal yang sama, terutama dalam Pasal 33. Akan tetapi, saat ini Pancasila dapat dikatakan menjadi sekadar aksesori politik belaka.

Memaknai kearifan lokal tampaknya tidak dapat dipisahkan dari konstelasi global. Indonesia dengan kekayaan alam yang melimpah dan posisinya yang strategis menjadikan Indonesia senantiasa menjadi incaran negara maju sejak zaman kolonial Hindia Belanda. Hingga kini pun setelah pemerintahan berganti beberapa kali, pemerintah tidak dapat menunjukkan independensinya: banyak kebijakan pemerintah yang lebih berpihak pada kepentingan kekuasaan ekonomi dan politik global daripada berpihak pada kepentingan rakyat dalam negeri. Tentang hal itu dapat dibaca tulisan Radhar Panca Dahana (2011) yang secara satiris mengatakan bagaimana kekuasaan pemerintahan telah menjadi kepanjangan tangan kepentingan ekonomi global.

Kearifan lokal (yang sesungguhnya dapat dipandang sebagai identitas bangsa) tidak akan bermakna apa pun tanpa dukungan ideologi yang berpihak kepadanya. Dalam konstelasi global, ketika perang dingin telah berakhir dengan runtuhnya Uni Soviet (dan negara yang masih menganut Marxisme pun telah menerapkan sistem ekonomi kapitalistik seperti Cina dan Vietnam), tanpa ideologi yang berpihak pada kepentingan nasional, kita akan semakin kehilangan identitas dalam percaturan global dan hanyut dalam arus globalisasi yang "didikte" oleh negara maju.

\section{Kearifan Lokal: antara Pusaka dan Senjata}

Kearifan lokal adalah warisan masa lalu yang berasal dari leluhur, yang tidak hanya terdapat dalam sastra tradisional (sastra lisan atau sastra tulis) sebagai refleksi masyarakat penuturnya, tetapi terdapat dalam berbagai bidang kehidupan nyata, seperti filosofi dan pandangan hidup, kesehatan, dan arsitektur. Dalam dialektika hidup-mati (sesuatu yang hidup akan mati), tanpa pelestarian dan revitalisasi, kearifan lokal pun suatu saat akan mati. Bisa jadi, nasib kearifan lokal mirip pusaka warisan leluhur, yang setelah sekian generasi akan lapuk dimakan rayap. Sekarang pun tanda pelapukan kearifan lokal makin kuat terbaca.

Kearifan lokal acap kali terkalahkan oleh sikap masyarakat yang makin pragmatis, yang akhirnya lebih 
berpihak pada tekanan dan kebutuhan ekonomi. Sebagai contoh, di salah satu wilayah hutan di Jawa Barat, mitos pengeramatan hutan yang sesungguhnya bertujuan melestarikan hutan/alam telah kehilangan tuahnya sehingga masyarakat sekitar dengan masa bodoh membabat dan mengubahnya menjadi lahan untuk berkebun sayur (Kompas, 23 April 2011). Ungkapan Jawa tradisional mangan ora mangan waton kumpul ('biar tidak makan yang penting berkumpul [dengan keluarga]') sekarang pun makin kehilangan maknanya: banyak perempuan di pedesaan yang berbondong-bondong mendaftarkan diri untuk bekerja di mancanegara dengan risiko terpisah dari keluarga daripada hidup menanggung kemiskinan dan kelaparan.

Kearifan lokal hanya akan abadi kalau kearifan lokal terimplementasikan dalam kehidupan konkret sehari-hari sehingga mampu merespons dan menjawab arus zaman yang telah berubah. Kearifan lokal juga harus terimplementasikan dalam kebijakan negara, misalnya dengan menerapkan kebijakan ekonomi yang berasaskan gotong royong dan kekeluargaan sebagai salah satu wujud kearifan lokal kita. Untuk mencapai itu, perlu implementasi ideologi negara (yakni Pancasila) dalam berbagai kebijakan negara. Dengan demikian, kearifan lokal akan efektif berfungsi sebagai senjata-tidak sekadar pusaka-yang membekali masyarakatnya dalam merespons dan menjawab arus zaman.

Revitalisasi kearifan lokal dalam merespons berbagai persoalan akut bangsa dan negara ini, seperti korupsi, kemiskinan, dan kesenjangan sosial hanya akan berjalan dengan dukungan kebijakan negara dan keteladanan. Tanpa itu, kearifan lokal hanya merupakan aksesori budaya yang tidak bermakna. Kearifan lokal di banyak daerah pada umumnya mengajarkan budaya malu (jika berbuat salah). Akan tetapi, dalam realitas sekarang, budaya malu itu telah luntur. Peraturan yang ada pun kadang-kadang memberi peluang kepada seorang terpidana atau bekas terpidana untuk menduduki jabatan publik. Jadi, budaya malu sebagai bagian dari kearifan lokal semestinya dapat direvitalisasi untuk memerangi korupsi, apalagi dalam agama pun dikenal konsep halal-haram (uang yang diperoleh dari korupsi adalah haram). 
Di antara berbagai penggerusan kearifan lokal saat ini, di sisi lain kita masih menyaksikan pemanfaatan kearifan lokal, misalnya di dunia medis terjadi pengembangan obat herbal yang merupakan warisan leluhur di bidang medis yang kemudian disempurnakan dengan standar farmakologi yang berlaku. Jadi, itu adalah salah satu wujud kearifan lokal yang telah memperoleh revitalisasi dalam masyarakat.

Di tengah derasnya arus investasi asing di bidang kuliner yang merambah ke negeri ini (seperti Kentucky Fried Chicken, Mc Donald, dan Pizza Hut), kita masih dapat menyaksikan menu kuliner lokal (masakan Sunda, Padang, dan Yogya) tetap eksis dan sebagian hadir dalam tata kelola restoran modern. Itu adalah revitalisasi kearifan lokal di bidang kuliner.

Sementara itu, gotong royong sebagai wujud kearifan lokal kita tampaknya belum terimplementasikan dalam perekonomian nasional yang makin didominasi oleh asing dan perusahaan multinasional dengan semangat neoliberalisme dan neokapitalisme. Perekonomian nasional yang berpijak dan tumbuh dari rakyat setidaknya mencerminkan identitas dan nasionalisme kita. Ketergantungan ekonomi pada asing akan menyebabkan kita dengan mudah didikte oleh kekuatan ekonomi dan politik asing dan hal itu akan mencederai kedaulatan kita sebagai bangsa.

\section{Kebudayaan sebagai Pendorong Pembangunan Nasional}

Indonesia memiliki tradisi dan sumber pengetahuan lokal yang sangat kaya dan hidup. Kedua hal tersebut dapat menjadi dasar yang kuat untuk membantu melaksanakan rencana pembangunan nasional", ujar Bambang Brodjonegoro, Menteri Perencanaan Pembangunan Nasional/Kepala Bappenas, dalam sambutannya di seminar nasional pada tanggal 4 April 2017 tentang "Peran Kebudayaan dalam Pembangunan Nasional”, yang diselenggarakan oleh Bappenas dan didukung oleh KSI.

Kebudayaan harus dianggap sebagai aset penting yang berkontribusi terhadap pembangunan nasional. Bapak Menteri menggarisbawahi bahwa Indonesia hanya dapat menjadi bangsa yang besar apabila mampu mengejawantahkan kebudayaan ke dalam pembangunan nasional. 
Seminar tersebut diselenggarakan untuk mewujudkan pembuatan kebijakan yang lebih baik dalam pembangunan nasional, yang tidak meninggalkan kearifan lokal, dimana hal tersebut telah diperoleh dan dikumpulkan selama bertahuntahun melalui pengalaman langsung, dan tercermin dalam ekspresi kebudayaan. Kearifan lokal dapat memberikan masukan yang signifikan untuk menjamin keberhasilan pelaksanaan pembangunan nasional tanpa memicu perlawanan lokal.

Pembangunan nasional bukanlah hanya terkait dengan peningkatkan kesejahteraan ekonomi masyarakat, tapi juga peningkatan seluruh aspek kehidupan masyarakat. Untuk itu, memahami kebudayaan lokal merupakan sesuatu yang penting bagi pembangunan nasional. Dalam sektor pendidikan, misalnya, kurikulum nasional belum tentu cocok untuk diterapkan di komunitas atau suku lokal tertentu. Saur "Butet" Marlina Manurung adalah seorang antropolog dan ahli pendidikan, dan dalam presentasinya mengatakan bahwa bagi anak-anak dari suku terpencil, pendidikan bukanlah untuk mengejar nilai yang tinggi. Pendidikan bagi mereka berarti memperoleh dan menguasai hal-hal untuk membela diri dan lingkungan mereka agar tidak dieksploitasi. Sokola Rimba yang didirikannya merupakan organisasi nirlaba yang bertujuan untuk memberikan program literasi dan advokasi bagi Masyarakat Adat dan Terpinggirkan di seluruh nusantara. Melalui pendidikan dari sudut pandang berbeda, mereka dapat mewariskan kebudayaan dan kearifan mereka ke generasi berikutnya. Lagu daerah, serta norma dan nilai tradisional, dapat ditulis dan didokumentasikan dalam bahasa ibu mereka sendiri.

Melestarikan dan mendayagunakan kebudayaan dapat menjadi hal yang efektif dalam mendorong ekonomi, sebagaimana dibuktikan oleh Kabupaten Banyuwangi, Jawa Timur. Dalam lima tahun terakhir, Banyuwangi telah berhasil mendorong perekonomiannya dengan memanfaatkan kebudayaan, melalui berbagai acara dan perayaan. Pada 2012, Pemerintah Kabupaten Banyuwangi telah menyelenggarakan 12 acara kebudayaan, sedangkan di tahun 2017, jumlah tersebut meningkat menjadi lebih dari 70 acara kebudayaan kepada turis lokal dan asing. Peningkatan pariwisata ini telah membuat pendapatan asli daerah Banyuwangi melonjak, 
sehingga meningkatkan perekonomian setempat, dari salah satu PDB per kapita terendah di Jawa Timur, menjadi tiga teratas hanya dalam lima tahun. Contoh lain bagaimana kebudayaan dapat mendongkrak perekonomian ke arah yang lebih baik dapat dilihat di Bali, yang sudah sangat terkenal di dunia, kebudayaan batik Jawa, dan Karnaval Busana Jember atau Jember Fashion Carnival (JFC), yang telah menelurkan puluhan Karnaval lain di seluruh negeri. Pimpinan karismatik JFC, Dynand Fariz, membawakan presentasi penuh warna terkait bagaimana kebudayaan dapat digunakan untuk menyokong pariwisata dan sektor usaha.

Kisah keberhasilan Banyuwangi dan Jember dapat diadaptasi dan direplikasi di daerah lain di Indonesia, dalam rangka membantu mewujudkan pembangunan nasional lewat kebudayaan. Karena setiap daerah memiliki kebudayaan uniknya masing-masing, replikasi ini sebaiknya difokuskan pada metodenya, seperti penggunaan teknologi informasi. Misalnya, Pemerintah Kabupaten Banyuwangi tidak memperbolehkan pengembang untuk membangun pusat perbelanjaan modern dalam Kabupaten. Sebaliknya, pemerinteh daerah telah membangun mal daring yang menjual berbagai produk lokal. Hal ini menarik tidak hanya pembeli domestik, tapi juga internasional.

Di tingkat nasional, tantangan untuk menggabungkan kebudayaan ke dalam pembangunan nasional berada pada aspek koordinasi antara berbagai kementerian dan lembaga yang terlibat dalam isu-isu terkait kebudayaan. Ini adalah salah satu isu penting yang dibahas dalam seminar tersebut. Hilmar Farid, Direktur Jenderal Kekebudayaanan, Kementerian Pendidikan dan Kekebudayaanan, mengatakan bahwa pemerintah harus juga memberikan perhatian kepada praktisi kebudayaan di wilayah terpencil, dan tidak hanya fokus pada mereka yang tinggal di kota-kota besar.

Pemerintah harus berperan aktif dalam melindungi, mengelola, dan memberikan arahan dan strategi untuk memanfaatkan kebudayaan sebagai aset pembangunan nasional. Menurut Melani Budianta, Profesor Kajian Kebudayaan Universitas Indonesia, pemerintah juga harus mampu menentukan sasaran dari pembangunan nasional berbasis kebudayaan. Prinsip dasarnya, ujar Budianta, adalah melalui kebijakan inklusif yang non-diskriminatif, 
berdasarkan partisipasi masyarakat lokal. Kebijakan yang demikian menjamin tidak seorang pun yang tertinggal dalam proses pembangunan. Ia juga mendorong agar setiap daerah mengembangkan potensi kebudayaannya sendiri dan membangun sinergi kebudayaan antar warga masyarakat yang dapat memberikan wawasan berharga kepada pemerintah terkait arah dari pembangunan nasional. Menggabungkan kebudayaan ke dalam pembangunan merupakan cara untuk membentuk dan melestarikan identitas Indonesia sebagai bangsa dengan kebudayaan yang kaya raya 


\section{BAB 10 \\ KEBIJAKAN PELESTARIAN KEARIFAN LOKAL}

\section{A. Kearifan Lokal Dalam Mewujudkan Lingkungan Yang Produktif}

Kearifan lokal adalah pandangan dari suatu tempat yang bersifat bijaksana dan bernilai, baik yang diikuti dan dipercayai oleh masyarakat di suatu tempat tersebut dan sudah diikuti secara turun temurun. Kearifan lokal tersebut menjadi penting dan bermanfaat hanya ketika masyarakat lokal yang mewarisi sistem pengetahuan itu mau menerima dan mengklaim hal itu sebagai bagian dari kehidupan mereka.

Dengan cara mewarisi pengetahuan scara turun temurun, kearifan lokal dapat disebut sebagai jiwa dari budaya lokal. Hal itu dapat dilihat dari ekspresi kearifan lokal dalam kehidupan sehari-hari karena telah terinternalisasi dengan sangat baik. Setiap bagian dari kehidupan masyarakat

local tersebut akan selalu berhubungan dengan lingkungan hidup. Menurut Undang-Undang Republik Indonesia nomor 32 tahun 2009 tentang Perlindungan dan Pengelolaan Lingkungan Hidup, kearifan lokal adalah nilai-nilai luhur yang berlaku dalam tata kehidupan masyarakat untuk antara lain melindungi dan mengelola lingkungan hidup secara lestari.

Kearifan lokal akan selalu terhubung pada kehidupan manusia yang hidup di lingkungan hidup yang arif. Karena lingkungan hidup merupakan kesatuan ruang dengan semua benda yang berada didalamnya baik itu makhluk hidup maupun benda mati. Dalam Undang-undang Republik Indonesia Nomor 23 Tahun 1997 tentang ketentuanketentuan pokok pengelolaan lingkungan hidup dinyatakan bahwa lingkungan adalah kesatuan ruang dengan semua benda, daya keadaan, dan makhluk hidup, termasuk di dalamnya manusia, dan perilakunya yang mempengaruhi kelangsungan perikehidupan dan kesejahteraan manusia serta makhluk hidup lainnya.

Dalam kehidupan sehari-hari, segala aktivitas yang dilakukan oleh manusia secara perlahan akan membawa pengaruh terhadap lingkungan disekitarnya, baik itu membawa pengaruh yang positif maupun negatif. Oleh sebab 
itu, manusia harus menyadari bahwa segala aktivitas yang dilakukan harus dapat memberikan pengaruh yang positif terhadap lingkungannya dengan menjaga dan melestarikan daya dukung lingkungan tersebut.

Lingkungan memiliki unsur-unsur didalamnya, yaitu biotik, abiotik dan sosial budaya. Biotik merupakan unsurunsur lingkungan hidup yang terdiri dari segala jenis makhluk hidup, mulai dari manusia, hewan, tumbuhan, maupun organisme atau jasad renik lainnya. Sedangkan, abiotik merupakan segala unsur lingkungan yang terdiri dari bendabenda mati seperti air, udara, dan lain-lain. Dan sosial budaya terdiri dari unsur lingkungan yang diciptakan manusia yang di dalamnya terdapat nilai, gagasan, norma, keyakinan, serta perilaku manusia sebagai makhluk sosial atau makhluk yang tidak dapat hidup sendiri.

Lingkungan hidup yang serasi dan seimbang sangat diperlukan sebagai penentu kehidupan suatu bangsa. Idealnya, pemanfaatan lingkungan hidup harus memperhatikan pemeliharaan dan kelestarian lingkungan sehingga dapat diwariskan kepada generasi yang akan datang. Setiap pemanfaatan lingkungan hidup harus bertujuan, seperti tercapainya keselarasan, keserasian, dan keseimbangan antara manusia dan lingkungan hidup; terwujudnya manusia Indonesia sebagai insan lingkungan hidup yang memiliki sikap dan tindakan melindungi serta membina lingkungan hidup; terjaminnya kepentingan generasi masa kini dan generasi masa depan; tercapainya kelestarian fungsi lingkungan hidup; terkendalinya pemanfaatan sumber daya secara bijaksana; terlindunginya Indonesia terhadap dampak dari luar yang dapat menyebabkan pencemaran atau kerusakan lingkungan.

Kelestarian lingkungan dipengaruhi oleh lingkungan yang didominasi dengan struktur buatan manusia yang merupakan lingkungan binaan. Bangunan dan infrastruktur buatan manusia bertanggung jawab untuk sebagian besar penggunaan energi, penggunaan banyak air, dan menghasilkan sejumlah besar limbah. Idealnya, sebuah bangunan harus beroperasi seefisien mungkin. Efisiensi merupakan salah satu dasar dari desain yang berkelanjutan, yang memengaruhi semua aspek proyek, mulai dari penentuan lokasi, perencanaan ruang, penggunaan material, 
dan sistem. Oleh sebab itu, para perencana dan perancang bangunan selain menciptakan bangunan yang indah harus juga memperhatikan efisiensi, kenyamanan serta pengaruh keberadaan bangunan tersebjut terhadap lingkungan disekitarnya. Efisiensi energi merupakan inti praktik desain hijau saat ini.

Pembangunan-pembangunan tersebut yang memenuhi kebutuhan masa kini tanpa harus mengurangi kemampuannya untuk memenuhi kebutuhan dari generasi yang akan datang merupakan pembangunan berkelanjutan. Pembangunan berkelanjutan harus memerhatikan pemanfaatan lingkungan hidup dan kelestarian lingkungannya agar kualitas lingkungan tetap terjaga. Kelestarian lingkungan yang tidak dijaga akan menyebabkan daya dukung lingkungan berkurang, atau bahkan akan hilang. Pembangunan berkelanjutan mengandung arti sudah tercapainya keadilan sosial dari generasi ke generasi. Dilihat dari pengertian lainnya, pembangunan berkelanjutan sebagai pembangunan nasional yang melestarikan fungsi dan kemampuan ekosistem.

Pengukuran atas pemanfaatan sumber daya pada ekosistem yang dilakukan secara seminimal mungkin guna menghasilkan produksi semaksimal mungkin dan juga merupakan suatu kegiatan yg menghasilkan sesuatu, berupa hal baru yg di dapat dari membaca, benda, tulisan, dan hal baik lainnya disebut produktif . Terdapat dua cara pandang produktivitas, yaitu cara pandang tradisional dan cara pandang modern. Cara pandang Tradisional membandingkan antara output fisik dengan input sumber daya yang digunakan sedangkan cara pandang modern membandingkan antara output fisik dengan kualitas yang dihasilkan.

Prinsip dalam manajemen produktivitas adalah efektif dalam mencapai tujuan dan efisien dalam menggunakan sumber daya. Unsur-unsur yang terdapat dalam produktivitas diantaranya efesiensi, efektivitas, dan kualitas. Efesiensi merupakan suatu ukuran dalam membandingkan penggunaan masukan (input) yang direncanakan dengan penggunaaan masukan yang sebenarnya terlaksana. Pengertian efisiensi beriorientasi kepada masukan. Sedangkan, efektivitas merupaka suatu ukuran yang memberikan gambaran seberapa jauh targer yang dapat tercapai baik secara kuatitas 
maupun waktu. Makin besar persentase target tercapai,makin tinggi tingkat efektivitasnya. Dan kualitas merupakan salah satu ukuran produktivitas. Meskipun kualitas sulit diukur secara matematis melalui rasio output/input, namun jelas bahwa kualitas input dan kualitas proses akan meningkatkan kualitas output.

Peningkatan produktivitas perlu dilakukan pada seluruh sektor mulai dari peningkatan produktivitas masyarakat, pemerintah hingga sektor swasta. Peningkatan produktivitas pada sektor swasta berarti meningkatkan produktivitas perusahaan. Hasil peningkatan produktivitas perusahaan terbukti telah memberikan manfaat kepada seluruh pemangku kepentingan mulai dari para pekerja perusahaan itu sendiri sampai dengan konsumen. Peningkatan produktivitas perusahaan juga memberikan manfaat besar kepada pemerintah dalam hal peningkatan dayasaing dan perluasan kesempatan kerja yang sangat dibutuhkan seiring dangan berkembangnya tuntutan pasar kerja. Oleh karena itu pemerintah berupaya secara terus menerus untuk mendorong dan memfasilitasi peningkatan produktivitas perusahaan.

Peningkatan produktivitas perlu dilakukan pada seluruh sektor mulai dari peningkatan produktivitas masyarakat, pemerintah hingga sektor swasta. Peningkatan produktivitas pada sektor swasta berarti meningkatkan produktivitas perusahaan. Hasil peningkatan produktivitas perusahaan terbukti telah memberikan manfaat kepada seluruh pemangku kepentingan mulai dari para pekerja perusahaan itu sendiri sampai dengan konsumen. Peningkatan produktivitas perusahaan juga memberikan manfaat besar kepada pemerintah dalam hal peningkatan dayasaing dan perluasan kesempatan kerja yang sangat dibutuhkan seiring dangan berkembangnya tuntutan pasar kerja. Oleh karena itu pemerintah berupaya secara terus menerus untuk mendorong dan memfasilitasi peningkatan produktivitas perusahaan.

Peningkatan produktivitas pada sektor masyarakat meningkatkan produktivitas lingkungan. Peningkatan pada sektor pemerintah meningkatkan produktivitas lembaga dan pada sektor swasta meningkatkan produktivitas perusahaan. Hasil peningkatan produktivitas perusahaan terbukti telah 
memberikan manfaat kepada seluruh pemangku kepentingan mulai dari para pekerja perusahaan itu sendiri sampai dengan konsumen. Peningkatan produktivitas perusahaan juga memberikan manfaat besar kepada pemerintah dalam hal peningkatan dayasaing dan perluasan kesempatan kerja yang sangat dibutuhkan seiring dangan berkembangnya tuntutan pasar kerja. Oleh karena itu pemerintah berupaya secara terus menerus untuk mendorong dan memfasilitasi peningkatan produktivitas swasta seperti perusahaan,produktivitas pemerintah seperti lembaga, dan produktivitas masyarakat seperti lingkungan.

Produktivitas masyarakat pada lingkungan hidup dapat dilakukan secara lokal. Dengan memanfaatkan sumber daya alam pada ekosistem secara produktif dan melakukan pelestarian lingkungan secara arif, maka dapat mewujudkan lingkungan yang produktif dengan kearifan lokal yang berkelanjutan. 


\section{BAB 11 \\ MANFAAT KEARIFAN LOKAL DALAM KONTEKS \\ PEMBANGUNAN DI INDONESIA}

\section{A. Kearifan Lokal}

Kearifan lokal dapat didefinisikan sebagai suatu kekayaan budaya lokal yang mengandung kebijakan hidup; pandangan hidup (way of life) yang mengakomodasi kebijakan (wisdom) dan kearifan hidup. Di Indonesia-yang kita kenal sebagai Nusantara-kearifan lokal itu tidak hanya berlaku secara lokal pada budaya atau etnik tertentu, tetapi dapat dikatakan bersifat lintas budaya atau lintas etnik sehingga membentuk nilai budaya yang bersifat nasional. Sebagai contoh, hampir di setiap budaya lokal di Nusantara dikenal kearifan lokal yang mengajarkan gotong royong, toleransi, etos kerja, dan seterusnya. Pada umumnya etika dan nilai moral yang terkandung dalam kearifan lokal diajarkan turuntemurun, diwariskan dari generasi ke generasi melalui sastra lisan (antara lain dalam bentuk pepatah dan peribahasa, folklore), dan manuskrip.

Walaupun ada upaya pewarisan kearifan lokal dari generasi ke generasi, tidak ada jaminan bahwa kearifan lokal akan tetap kukuh menghadapi globalisasi yang menawarkan gaya hidup yang makin pragmatis dan konsumtif. Secara faktual dapat kita saksikan bagaimana kearifan lokal yang sarat kebijakan dan filosofi hidup nyaris tidak terimplementasikan dalam praktik hidup yang makin pragmatis. Korupsi yang merajalela hampir di semua level adalah bukti nyata pengingkaran terhadap kearifan lokal yang mengajarkan "bersakit-sakit dahulu, bersenang-senang kemudian"; "hemat pangkal kaya".

\section{B. Kearifan Lokal sebagai Identitas dan Ideologi Bangsa}

Boni Hargens (2011) dalam tulisannya di Kompas menyatakan bahwa arus modernisasi, liberalisasi, dan globalisasi semestinya tidak meniadakan suatu negara jatuh dalam percaturan global asal saja negara tersebut ditopang oleh identitas nasional yang kuat, tetapi juga didukung oleh ideologi dan kepemimpinan politik yang kuat. 
Selain etika moral yang bersumber pada agama, di Indonesia juga terdapat kearifan lokal yang menuntun masyarakat kedalam hal pencapaian kemajuan dan keunggulan, etos kerja, serta keseimbangan dan keharmonisan alam dan sosial. Kita mengenal pepatah "gantungkan cita-citamu setinggi bintang di langit", "bersakitsakit dahulu bersenang-senang kemudian" yang mengimplikasikan ajakan untuk membangun etos kerja dan semangat untuk meraih keunggulan. Dalam hal keharmonisan sosial dan alam, hampir semua budaya di Indonesia mengenal prinsip gotong royong dan toleransi. Dalam suku tertentu yang bermukim di pedalaman juga dikenal kearifan lokal yang bersifat menjaga dan melestarikan alam sehingga alam (misalnya kayu di hutan) hanya dimanfaatkan seperlunya, tidak dikuras habis.

Dengan sumber daya alam yang melimpah dan sumber daya manusia yang banyak, semestinya Indonesia telah menjadi negara besar yang maju. Namun, di tingkat Asia Tenggara saja posisi kita di bawah Singapura yang miskin sumber daya alam dengan luas wilayah lebih kurang hanya seluas Jakarta. Sumber daya alam yang melimpah di negeri ini kadang-kadang juga tidak menjadi berkah. Gas alam diekspor ke luar negeri dengan harga jual yang lebih rendah daripada harga jual untuk pasar dalam negeri. Hutan dieksploitasi secara luar biasa untuk mengejar perolehan devisa yang pada akhirnya hanya mendatangkan kerusakan ekosistem alam yang disusul dengan bencana (banjir;longsor).

Kebijakan ekonomi pemerintah acap kali hanya berpihak pada kepentingan pemodal kuat. Padahal, Pasal 33 Undang-Undang Dasar 1945-yang oleh para pendiri republik ini diciptakan untuk mengakomodasi kearifan lokal yang ada di negeri ini (seperti gotong royong dan kekeluargaan)dengan tegas mengamanatkan bahwa perekonomian nasional disusun berdasarkan asas kekeluargaan dan sumber daya alam yang ada dikuasai negara untuk kemakmuran rakyat. Secara faktual, dapat kita saksikan pertumbuhan mini market yang sangat subur yang mematikan warung rumah tangga.

Sementara itu, dalam masyarakat sendiri sering terjadi tindak kekerasan yang mereduksi nilai toleransi. Dalam konteks perubahan nilai sosiokultural juga terjadi pergeseran orientasi nilai. Masyarakat cenderung makin 
pragmatis dan makin berorientasi pada budaya uang serta terperangkap dalam gaya hidup konsumtif yang disodorkan kekuatan global kapitalisme.

Dalam realitas Indonesia kini, secara ekstrem dapat dikatakan bahwa kearifan lokal yang kita miliki mirip benda pusaka, yang kita warisi dari leluhur, kita simpan dan kita pelihara, tetapi kita tidak mampu mengimplementasikannya dalam kehidupan nyata sehingga pusaka tersebut sia-sia merespons tantangan zaman yang telah berubah.

Dalam kaitannya dengan kearifan lokal dan realitas Indonesia kini, Kompas edisi 20 April 2011 menampilkan dua tulisan yang relevan, yakni "Saya Mohon Ampun" oleh Radhar Panca Dahana dan "Pembangunan Gerus Kearifan Lokal" oleh Wasisto Raharjo Jati. Dalam tulisannya, Radhar Panca Dahana mencemaskan perilaku para elit negeri ini yang antara sadar dan tidak sadar telah menjadi agen kepentingan dan keserakahan ekonomi dan politik negara maju (sehingga Indonesia hanya dijadikan sekadar pasar sambil dikuras habis sumber daya alamnya). Sementara itu, Wasisto Raharjo Jati mengemukakan bahwa pembangunan di Indonesia yang terpaku pada pertumbuhan ekonomi semata telah mengabaikan kearifan lokal dan menimbulkan potensi konflik vertikal dan horizontal di kemudian hari. Karena berorientasi pada pertumbuhan ekonomi, secara tidak langsung pemerintah juga telah menjejalkan "budaya uang" sehingga cenderung mengurangi dan meniadakan kearifan dan budaya lokal.

Kearifan lokal dapat dipandang sebagai identitas bangsa, terlebih dalam konteks Indonesia yang memungkinkan kearifan lokal bertransformasi secara lintas budaya yang pada akhirnya melahirkan nilai budaya nasional. Di Indonesia, kearifan lokal adalah filosofi dan pandangan hidup yang mewujud dalam berbagai bidang kehidupan (tata nilai sosial dan ekonomi, arsitektur, kesehatan, tata lingkungan, dan sebagainya). Sekadar contoh, kearifan lokal yang bertumpu pada keselarasan alam telah menghasilkan pendopo dalam arsitektur Jawa. Pendopo dengan konsep ruang terbuka menjamin ventilasi dan sirkulasi udara yang lancar tanpa perlu penyejuk udara.

Pendopo adalah salah satu contoh bagaimana kearifan lokal warisan masa lampau telah memberikan kepada kita 
konsep arsitektur yang lega, nyaman, dan hemat energi. Sekarang ini, kita mempersoalkan krisis energi dan menyerukan hemat energi. Namun, gedung dan rumah dibangun dengan konsep bangunan tertutup sehingga memerlukan penyejuk udara yang boros energi.

Kearifan lokal dalam wujud gotong royong juga kita kenal di warung rakyat (misalnya warteg). Di warung tersebut dipraktikkan penggiliran pengelolaan warung sebagai implementasi nilai gotong royong dalam tata sosial dan ekonomi: memberi peluang kerja dan peluang mencari nafkah bagi kerabat dan warga sekampung; itu adalah salah satu kearifan lokal warisan masa lampau yang masih diberlakukan oleh sebagian masyarakat.

Di negeri ini, ada sesuatu yang aneh dan janggal: kearifan lokal di tingkat akar rumput acap kali berhadapan dengan kebijakan pemerintah yang pro pertumbuhan ekonomi (sehingga mengundang investor asing dan memberikan banyak kemudahan, termasuk dalam hal regulasi, sambil mengabaikan kearifan lokal yang tumbuh di akar rumput (Radhar Panca Dahana dan Wasisto Raharjo Jati, 2011).

Pancasila sebagai ideologi negara pada dasarnya telah mengakomodasi kearifan lokal yang hidup di Nusantara (antara lain nilai gotong royong sehingga salah satu sila Pancasila adalah "keadilan sosial bagi seluruh rakyat Indonesia"). UUD 1945 (yang dijiwai oleh Pancasila) juga mengamanatkan hal yang sama, terutama dalam Pasal 33. Akan tetapi, saat ini Pancasila dapat dikatakan menjadi sekadar aksesori politik belaka.

Memaknai kearifan lokal tampaknya tidak dapat dipisahkan dari konstelasi global. Indonesia dengan kekayaan alam yang melimpah dan posisinya yang strategis menjadikan Indonesia senantiasa menjadi incaran negara maju sejak zaman kolonial Hindia Belanda. Hingga kini pun setelah pemerintahan berganti beberapa kali, pemerintah tidak dapat menunjukkan independensinya: banyak kebijakan pemerintah yang lebih berpihak pada kepentingan kekuasaan ekonomi dan politik global daripada berpihak pada kepentingan rakyat dalam negeri. Tentang hal itu dapat dibaca tulisan Radhar Panca Dahana (2011) yang secara 
satiris mengatakan bagaimana kekuasaan pemerintahan telah menjadi kepanjangan tangan kepentingan ekonomi global.

Kearifan lokal (yang sesungguhnya dapat dipandang sebagai identitas bangsa) tidak akan bermakna apa pun tanpa dukungan ideologi yang berpihak kepadanya. Dalam konstelasi global, ketika perang dingin telah berakhir dengan runtuhnya Uni Soviet (dan negara yang masih menganut Marxisme pun telah menerapkan sistem ekonomi kapitalistik seperti Cina dan Vietnam), tanpa ideologi yang berpihak pada kepentingan nasional, kita akan semakin kehilangan identitas dalam percaturan global dan hanyut dalam arus globalisasi yang "didikte" oleh negara maju.

\section{Kearifan Lokal: antara Pusaka dan Senjata}

Kearifan lokal adalah warisan masa lalu yang berasal dari leluhur, yang tidak hanya terdapat dalam sastra tradisional (sastra lisan atau sastra tulis) sebagai refleksi masyarakat penuturnya, tetapi terdapat dalam berbagai bidang kehidupan nyata, seperti filosofi dan pandangan hidup, kesehatan, dan arsitektur. Dalam dialektika hidup-mati (sesuatu yang hidup akan mati), tanpa pelestarian dan revitalisasi, kearifan lokal pun suatu saat akan mati. Bisa jadi, nasib kearifan lokal mirip pusaka warisan leluhur, yang setelah sekian generasi akan lapuk dimakan rayap. Sekarang pun tanda pelapukan kearifan lokal makin kuat terbaca.

Kearifan lokal acap kali terkalahkan oleh sikap masyarakat yang makin pragmatis, yang akhirnya lebih berpihak pada tekanan dan kebutuhan ekonomi. Sebagai contoh, di salah satu wilayah hutan di Jawa Barat, mitos pengeramatan hutan yang sesungguhnya bertujuan melestarikan hutan/alam telah kehilangan tuahnya sehingga masyarakat sekitar dengan masa bodoh membabat dan mengubahnya menjadi lahan untuk berkebun sayur (Kompas, 23 April 2011). Ungkapan Jawa tradisional mangan ora mangan waton kumpul ('biar tidak makan yang penting berkumpul [dengan keluarga]') sekarang pun makin kehilangan maknanya: banyak perempuan di pedesaan yang berbondong-bondong mendaftarkan diri untuk bekerja di mancanegara dengan risiko terpisah dari keluarga daripada hidup menanggung kemiskinan dan kelaparan. 
Kearifan lokal hanya akan abadi kalau kearifan lokal terimplementasikan dalam kehidupan konkret sehari-hari sehingga mampu merespons dan menjawab arus zaman yang telah berubah. Kearifan lokal juga harus terimplementasikan dalam kebijakan negara, misalnya dengan menerapkan kebijakan ekonomi yang berasaskan gotong royong dan kekeluargaan sebagai salah satu wujud kearifan lokal kita. Untuk mencapai itu, perlu implementasi ideologi negara (yakni Pancasila) dalam berbagai kebijakan negara. Dengan demikian, kearifan lokal akan efektif berfungsi sebagai senjata-tidak sekadar pusaka-yang membekali masyarakatnya dalam merespons dan menjawab arus zaman.

Revitalisasi kearifan lokal dalam merespons berbagai persoalan akut bangsa dan negara ini, seperti korupsi, kemiskinan, dan kesenjangan sosial hanya akan berjalan dengan dukungan kebijakan negara dan keteladanan. Tanpa itu, kearifan lokal hanya merupakan aksesori budaya yang tidak bermakna. Kearifan lokal di banyak daerah pada umumnya mengajarkan budaya malu (jika berbuat salah). Akan tetapi, dalam realitas sekarang, budaya malu itu telah luntur. Peraturan yang ada pun kadang-kadang memberi peluang kepada seorang terpidana atau bekas terpidana untuk menduduki jabatan publik. Jadi, budaya malu sebagai bagian dari kearifan lokal semestinya dapat direvitalisasi untuk memerangi korupsi, apalagi dalam agama pun dikenal konsep halal-haram (uang yang diperoleh dari korupsi adalah haram).

Di antara berbagai penggerusan kearifan lokal saat ini, di sisi lain kita masih menyaksikan pemanfaatan kearifan lokal, misalnya di dunia medis terjadi pengembangan obat herbal yang merupakan warisan leluhur di bidang medis yang kemudian disempurnakan dengan standar farmakologi yang berlaku. Jadi, itu adalah salah satu wujud kearifan lokal yang telah memperoleh revitalisasi dalam masyarakat.

Di tengah derasnya arus investasi asing di bidang kuliner yang merambah ke negeri ini (seperti Kentucky Fried Chicken, Mc Donald, dan Pizza Hut), kita masih dapat menyaksikan menu kuliner lokal (masakan Sunda, Padang, dan Yogya) tetap eksis dan sebagian hadir dalam tata kelola restoran modern. Itu adalah revitalisasi kearifan lokal di bidang kuliner. 
Sementara itu, gotong royong sebagai wujud kearifan lokal kita tampaknya belum terimplementasikan dalam perekonomian nasional yang makin didominasi oleh asing dan perusahaan multinasional dengan semangat neoliberalisme dan neokapitalisme. Perekonomian nasional yang berpijak dan tumbuh dari rakyat setidaknya mencerminkan identitas dan nasionalisme kita. Ketergantungan ekonomi pada asing akan menyebabkan kita dengan mudah didikte oleh kekuatan ekonomi dan politik asing dan hal itu akan mencederai kedaulatan kita sebagai bangsa.

\section{Kebudayaan sebagai Pendorong Pembangunan Nasional} Indonesia memiliki tradisi dan sumber pengetahuan lokal yang sangat kaya dan hidup. Kedua hal tersebut dapat menjadi dasar yang kuat untuk membantu melaksanakan rencana pembangunan nasional", ujar Bambang Brodjonegoro, Menteri Perencanaan Pembangunan Nasional/Kepala Bappenas, dalam sambutannya di seminar nasional pada tanggal 4 April 2017 tentang "Peran Kebudayaan dalam Pembangunan Nasional", yang diselenggarakan oleh Bappenas dan didukung oleh KSI.

Kebudayaan harus dianggap sebagai aset penting yang berkontribusi terhadap pembangunan nasional. Bapak Menteri menggarisbawahi bahwa Indonesia hanya dapat menjadi bangsa yang besar apabila mampu mengejawantahkan kebudayaan ke dalam pembangunan nasional.

Seminar tersebut diselenggarakan untuk mewujudkan pembuatan kebijakan yang lebih baik dalam pembangunan nasional, yang tidak meninggalkan kearifan lokal, dimana hal tersebut telah diperoleh dan dikumpulkan selama bertahuntahun melalui pengalaman langsung, dan tercermin dalam ekspresi kebudayaan. Kearifan lokal dapat memberikan masukan yang signifikan untuk menjamin keberhasilan pelaksanaan pembangunan nasional tanpa memicu perlawanan lokal.

Pembangunan nasional bukanlah hanya terkait dengan peningkatkan kesejahteraan ekonomi masyarakat, tapi juga peningkatan seluruh aspek kehidupan masyarakat. Untuk itu, memahami kebudayaan lokal merupakan sesuatu yang penting bagi pembangunan nasional. Dalam sektor 
pendidikan, misalnya, kurikulum nasional belum tentu cocok untuk diterapkan di komunitas atau suku lokal tertentu. Saur "Butet" Marlina Manurung adalah seorang antropolog dan ahli pendidikan, dan dalam presentasinya mengatakan bahwa bagi anak-anak dari suku terpencil, pendidikan bukanlah untuk mengejar nilai yang tinggi. Pendidikan bagi mereka berarti memperoleh dan menguasai hal-hal untuk membela diri dan lingkungan mereka agar tidak dieksploitasi. Sokola Rimba yang didirikannya merupakan organisasi nirlaba yang bertujuan untuk memberikan program literasi dan advokasi bagi Masyarakat Adat dan Terpinggirkan di seluruh nusantara. Melalui pendidikan dari sudut pandang berbeda, mereka dapat mewariskan kebudayaan dan kearifan mereka ke generasi berikutnya. Lagu daerah, serta norma dan nilai tradisional, dapat ditulis dan didokumentasikan dalam bahasa ibu mereka sendiri.

Melestarikan dan mendayagunakan kebudayaan dapat menjadi hal yang efektif dalam mendorong ekonomi, sebagaimana dibuktikan oleh Kabupaten Banyuwangi, Jawa Timur. Dalam lima tahun terakhir, Banyuwangi telah berhasil mendorong perekonomiannya dengan memanfaatkan kebudayaan, melalui berbagai acara dan perayaan. Pada 2012, Pemerintah Kabupaten Banyuwangi telah menyelenggarakan 12 acara kebudayaan, sedangkan di tahun 2017, jumlah tersebut meningkat menjadi lebih dari 70 acara kebudayaan kepada turis lokal dan asing. Peningkatan pariwisata ini telah membuat pendapatan asli daerah Banyuwangi melonjak, sehingga meningkatkan perekonomian setempat, dari salah satu PDB per kapita terendah di Jawa Timur, menjadi tiga teratas hanya dalam lima tahun. Contoh lain bagaimana kebudayaan dapat mendongkrak perekonomian ke arah yang lebih baik dapat dilihat di Bali, yang sudah sangat terkenal di dunia, kebudayaan batik Jawa, dan Karnaval Busana Jember atau Jember Fashion Carnival (JFC), yang telah menelurkan puluhan Karnaval lain di seluruh negeri. Pimpinan karismatik JFC, Dynand Fariz, membawakan presentasi penuh warna terkait bagaimana kebudayaan dapat digunakan untuk menyokong pariwisata dan sektor usaha.

Kisah keberhasilan Banyuwangi dan Jember dapat diadaptasi dan direplikasi di daerah lain di Indonesia, dalam rangka membantu mewujudkan pembangunan nasional lewat 
kebudayaan. Karena setiap daerah memiliki kebudayaan uniknya masing-masing, replikasi ini sebaiknya difokuskan pada metodenya, seperti penggunaan teknologi informasi. Misalnya, Pemerintah Kabupaten Banyuwangi tidak memperbolehkan pengembang untuk membangun pusat perbelanjaan modern dalam Kabupaten. Sebaliknya, pemerinteh daerah telah membangun mal daring yang menjual berbagai produk lokal. Hal ini menarik tidak hanya pembeli domestik, tapi juga internasional.

Di tingkat nasional, tantangan untuk menggabungkan kebudayaan ke dalam pembangunan nasional berada pada aspek koordinasi antara berbagai kementerian dan lembaga yang terlibat dalam isu-isu terkait kebudayaan. Ini adalah salah satu isu penting yang dibahas dalam seminar tersebut. Hilmar Farid, Direktur Jenderal Kekebudayaanan, Kementerian Pendidikan dan Kekebudayaanan, mengatakan bahwa pemerintah harus juga memberikan perhatian kepada praktisi kebudayaan di wilayah terpencil, dan tidak hanya fokus pada mereka yang tinggal di kota-kota besar.

Pemerintah harus berperan aktif dalam melindungi, mengelola, dan memberikan arahan dan strategi untuk memanfaatkan kebudayaan sebagai aset pembangunan nasional. Menurut Melani Budianta, Profesor Kajian Kebudayaan Universitas Indonesia, pemerintah juga harus mampu menentukan sasaran dari pembangunan nasional berbasis kebudayaan. Prinsip dasarnya, ujar Budianta, adalah melalui kebijakan inklusif yang non-diskriminatif, berdasarkan partisipasi masyarakat lokal. Kebijakan yang demikian menjamin tidak seorang pun yang tertinggal dalam proses pembangunan. Ia juga mendorong agar setiap daerah mengembangkan potensi kebudayaannya sendiri dan membangun sinergi kebudayaan antar warga masyarakat yang dapat memberikan wawasan berharga kepada pemerintah terkait arah dari pembangunan nasional. Menggabungkan kebudayaan ke dalam pembangunan merupakan cara untuk membentuk dan melestarikan identitas Indonesia sebagai bangsa dengan kebudayaan yang kaya raya 


\section{BAB 12 \\ KEBIJAKAN PUBLIK DAN TANTANGAN \\ GLOBALISASI}

Secara Umum, globalisasi dipahami oleh George Ritzer sebagai suatu proses penyebaran kebiasaan-kebiasaan yang mendunia, ekspansi hubungan yang melintasi benua, organisasi dari kehidupan sosial pada skala global, dan pertumbuhan dari sebuah kesadaran global bersama.

Sementara menurut Anthony Giddens, globalisasi merupakan intensifikasi relasi sedunia yang menghubungkan lokalitas yang saling berjauhan sedemikian rupa sehingga sejumlah peristiwa sosial dibentuk oleh peristiwa yang terjadi pada jarak bermil-mil dan begitu pula sebaliknya. Dengan demikian dapat dikatakan bahwa globalisasi merupakan terintegrasinya segala aspek kehidupan manusia, mulai dari ekonomi, informasi, sistem politik sampai aspek budaya.

Pendek Kata, globalisasi telah membuat bumi yang kita diami ini seakan-akan seperti desa global yang saling terkoneksi dengan cepatnya antara satu dengan yang lainnya. Menggunakan kecanggihan teknologi, globalisasi membanjiri segenap penjuru dunia dengan arus informasi yang dengan mudahnya dapat diakses oleh setiap orang. Secara ekonomi, politik dan budaya, dunia seakan-akan tanpa sekat teritorial negara karena semuanya seakan menjadi satu dalam sebuah dunia.

Globalisasi secara masif diberlakukan di seluruh dunia sejak tahun 1980 seiring dengan kian dominannya Blok Barat yang dikomandoi oleh Amerika Serikat dalam percaturan dunia setelah kolapsnya Uni Sovyet dengan Blok Timurnya. Sebagai sebuah sistem, globalisasi tentu memunculkan dampaknya terhadap masyarakat dunia. Pada satu sisi, globalisasi berdampak positif bagi upaya memperoleh standar hidup yang layak. Hal ini karena globalisasi menyediakan arena berkompetisi yang sama bagi setiap negara untuk memanfaatkan peluang yang disediakan. Fenomena kesuksesan Tiongkok dan India yang memanfaatkan kesempatan-kesempatan yang disediakan globalisasi sehingga perekonomiannya mengalami peningkatan, bahkan kemudian 
menjadi dua kekuatan baru ekonomi dunia layak dikemukakan sebagai contoh.

Akan tetapi sebaliknya, globalisasi ternyata juga memunculkan ekses negatif di seluruh dunia. Menurut Petras and Veltmeyer, globalisasi hanya dinikmati oleh negaraNegara Maju, sementara negara-negara Dunia Ketiga hanya berperan sebagai penonton, bahkan menjadi korban dari beragam ekses negatif yang ditimbulkannya.

Menurut Shiva, globalisasi juga memarginalisasi petani yang ada di negara-negara Dunia Ketiga karena berbagai aturan perdagangan global membuat mereka semakin terpinggirkan, bahkan tercerabut dari sistem, profesi dan cara hidup yang selama ini dilakoninya.

Globalisasi juga diklaim Tauli-Corpuz justru mengikis sistem ekonomi dan kebudayaan lokal yang ada di negaranegara Dunia Ketiga karena proyek-proyek yang dibiayai oleh badan kapital (IMF) lebih banyak dilaksanakan di daerahdaerah tanpa ada pembicaraan terlebih dahulu dengan penduduk lokal.

Hirst and Thomspon juga mengatakan bahwa globalisasi yang diklaim sebagai sarana menuju kesejahteraan masyarakat dunia ini tidak lebih hanya sebuah mitos. Karenanya, Hirst and Thomspon mengajukan lima argumen untuk mendasari kesimpulannya tersebut.

Pertama, keterbukaan ekonomi internasional yang dijadikan jurus jitu para pendukung globalisasi untuk menarik simpati dunia sesungguhnya tidak lebih terbuka dibandingkan tahun 1870 sampai 1914.

Kedua, eksistensi perusahaan transnasional murni sebagai salah satu agen globalisasi sulit ditemukan karena meskipun berbasis nasional, tetapi pemasarannya menjangkau lintas negara dan internasional untuk memperkuat aset nasional, produksi dan penjualannya.

Ketiga, mobilitas modal yang diklaim para pendukung globalisasi akan mengalir deras ke Dunia Ketiga tidak sepenuhnya menjadi kenyataan karena lebih terkonsentrasi di negara-Negara Maju, sementara Dunia Ketiga tetap berada pada posisi terpinggirkan.

Keempat, tujuan akan terciptanya ekonomi sebagaimana yang diklaim para pendukung globalisasi sesungguhnya tidak benar-benar terjadi karena arus 
perdagangan, investasi dan keuangan global lebih banyak berkonsentrasi di Tri Tunggal Eropa (Inggris, Perancis dan Jerman), Jepang dan Amerika Utara, termasuk juga Tiongkok dan India.

Terakhir, oleh karena tidak merata di seluruh dunia, maka Inggris, Perancis, Jerman, Jepang, Amerika Serikat dan Kanada mengendalikan setiap aspek ekonomi dunia sejalan dengan tujuannya.

Sejalan dengan Hirst and Thomspon, Tandon mengajukan fakta terkait tidak globalnya perekonomian dunia karena hanya dikuasai dan didominasi oleh tiga kekuatan dunia. Ketiga kekuatan utama dunia yang dinamai sebagai Triad tersebut adalah Amerika Utara, Eropa Barat dan Asia Timur menguasai sumberdaya yang dimiliki kawasan yang dihegemoninya (hinterland).

Menurut Samir Amin, globalisasi adalah metamorphosis dari penjajahan ketiga yang dilakukan Barat terhadap Dunia Ketiga, setelah sebelumnya mempraktikkan merkantilisme dan imperialisme. Seiring dengan runtuhnya Uni Sovyet, maka pola imperialisme dalam format globalisasi yang dilakukan untuk memperkuat Trio Pusat (Amerika Serikat, Eropa Barat dan Jepang) mendapatkan dukungan dari beberapa kekuatan, yaitu wewenang untuk campur tangan dalam urusan dalam negeri negara lain yang diperkuat oleh demokrasi, hak rakyat dan kemanusiaan. Hal ini semakin diperkuat dengan strategi unjuk kekuatan militer Barat di berbagai negara yang berafiliasi dengannya untuk memastikan hegemoninya tetap kuat. Chakrabarty mengatakan bahwa globalisasi tidak lain merupakan manifestasi dari ambisi Eropa membangun kembali hegemoninya menggunakan serangkaian praktik imperialisme sejarah di negara-negara Dunia Ketiga.

Demikian sederet dampak dan pandangan positif dan negatif dari pemberlakukan globalisasi di seluruh dunia yang ditengarai oleh banyak kalangan. Di samping beberapa dampak di atas, globalisasi juga memunculkan perdebatan di kalangan ahli mengenai peran negara atau pemerintah dalam pembangunan. Sebagaimana dikemukakan sebelumnya bahwa globalisasi telah membuat bumi ini seakan seperti sebuah desa yang tidak disekat oleh batas-batas teritorial negara. Terintegrasinya dunia secara politik, ekonomi, budaya 
dan informasi membuat orang-orang dengan mudahnya dapat saling berinteraksi dan memanfaatkan peluang tanpa terkendala dengan status negara di manapun dan kapanpun. Akibatnya, batas-batas fisik terirorial negara melebur sehingga dengan demikian pemerintah pun dianggap tidak memiliki banyak peranan dalam pembangunan.

Isu peran yang dimainkan negara atau pemerintah menjadi salah satu tema sentral dalam perdebatan seputar globalisasi. Hal ini karena sebagai pihak yang diserahkan tanggungjawab pengelolaan negara, pemerintah sebagai manifestasi negara seharusnya berperan aktif dalam mengatasi masalah-masalah yang dihadapi rakyatnya. Peran dimaksud mewujudkan diri dalam kebijakan-kebijakan publik yang dimaknai oleh Steven A. Peterson sebagai tindakan yang dilakukan pemerintah untuk mengatasi beragam masalah. Begitu pula kebijakan publik yang dipahami oleh Leo Agustino sebagai sebuah tindakan yang dilakukan pihak oleh berwenang, memiliki maksud atau tujuan tertentu, tidak bersifat acak atau terencana, memiliki sasaran dan berorientasi pada tujuan, serta berlandaskan pada aturan yang berlaku. Globalisasi dengan segala dampaknya perlu mendapatkan perhatian dari pemerintah agar ekses positifnya dapat dimanfaatkan dengan baik dan ekses negatifnya dapat dihindari oleh rakyat.

Sebagai pihak yang secara konstitusional berperan penting dalam sebuah negara, pemerintah tidak selamanya menjadi pemain tunggal dalam pengelolaan negerinya. Catatan sejarah mengungkapkan dinamisnya peran yang dimainkan pemerintah dalam pembangunan negara. Ada saat ketika pemerintah sangat berperan, bahkan sangat absolut, dalam melakukan pembangunan dalam sebuah negara, akan tetapi ada pula masa dimana pemerintah tidak lebih sebagai pelengkap saja.

Menurut Budi Winarno, peran negara dalam pembangunan dapat dibagi menjadi dua bagian, yaitu: peran negara era tahun 1950-1960-an dan peran negara era 1970an sampai sekarang. Peran yang dimainkan negara di masa sebelum 1970-an sangat signifikan dalam menentukan arah dan kebijakan pembangunan suatu bangsa, tetapi setelah tahun 1970 sampai sekarang terjadi pemangkasan peran yang dimainkan negara. 
Perdebatan mengenai peran yang dijalan negara atau pemerintah dalam pembangunan ini menurut Anthony Giddens memunculkan dua kelompok besar yang masingmasing melahirkan teori, yaitu kelompok radikal di satu sisi dan kelompok skeptis di sisi yang lain. Secara umum, kelompok radikal diidentifikasikan sebagai kumpulan pemikir sosial yang mendukung globalisasi karena menganggapnya sebagai sebuah keniscayaan dalam kehidupan manusia, sementara skeptis dikenal sebagai kelompok intelektual yang meragukan kemungkinannya, bahkan menentang keberadaannya. Sebagai upaya mendukung pendapatnya, masing-masing kelompok ini mengajukan beragam asumsi dan data yang dimilikinya.

Peran negara dalam pembangunan dimulai selama Perang Dunia Kedua dengan mengendalikan seluruh kekuatan nasional. Menurut Abidin, peran pemerintah semakin signifikan setelah berakhirnya perang yang telah merusak beragam infrastruktur untuk meyakinkan rakyat akan keperluan pembangunan dan mengajaknya berpartisipasi, proses nasionalisasi beragam lembaga ekonomi yang ditinggalkan penjajah, koordinasi dan komplemantaritas antar berbagai industri dan bisnis, dan melakukan pembangunan berencana yang terpusat.

Teori Keynes menjadi landasan perlunya intervensi pemerintah dalam setiap aspek pembangunan yang diwujudkan dengan Program Marshall Plan sehingga mengantarkan Amerika dan Eropa berjaya dalam bidang ekonomi dan lain sebagainya. Langkah ini juga diikuti oleh beragam negara Dunia Ketiga, seperti Indonesia yang menerapkan Rencana Pembangunan Lima Tahun (Repelita), Malaysia yang menerapkan berbagai kebijakan untuk memacu industrialisasi berturut-turut mulai tahun 1970 sampai tahun 1995 dan India yang membentuk Komisi Perencanaan Nasional sebagai upaya mendorong Rencana Lima Tahunan.

Menurut Kamal Mathur, terdapat tiga cara yang dilakukan negara di masa sebelum tahun 1970 dalam upaya membangun bangsa, yaitu melalui belanja pemerintah, melalui mobilisasi sumberdaya dan melalui partisipasi dalam produksi industrial yang dilaksanakan dalam tiga wilayah kebijakan (investasi, perdagangan dan finansial). Wilayah pertama dilakukan negara dengan cara menerbitkan beragam 
kebijakan untuk menciptakan iklim investasi yang kondusif sebagai upaya menarik minat para investasi asing untuk menanamkan modalnya di dalam negeri. Hal yang sama juga dilakukan negara terkait dengan kebijakan-kebijakan pada aspek perdagangan dan finansial yang berintikan penciptaan iklim yang memungkinkan perekonomian dapat berkembang dengan baik.

Terkait dengan hal ini, Michael Todaro mengungkapkan faktor-faktor yang mendasari diperlukannya peran negara dalam pembangunan, yaitu: kegagalan pasar, mobilisasi sumberdaya dan dampak psikologis. Kegagalan pasar dalam menstabilisasikan komoditas dan harga berdampak pada mislokasi sumberdaya yang dapat berbahaya di masa mendatang. Mobilisasi sumberdaya diperlukan karena negara-negara berkembang umumnya menghadapi kendala kualitas sumberdaya manusia sehingga dengan adanya peran pemerintah membuat arah pembangunan menjadi lebih fokus. Dengan peran negara yang kuat dan dominan akan berdampak psikologis bagi masyarakat sehingga akan tercipta pembangunan yang dapat mencapai tujuan-tujuan yang diharapkan.

Peran negara yang dominan dalam pembangunan setelah Perang Dunia Kedua mulai mendapatkan kritikan yang dimulai pada tahun 1970 seiring dengan melambatnya perekonomian Amerika dan Eropa setelah berjaya selama hampir 25 tahun. Upaya mengurangi peran negara pertama kali dilakukan oleh Inggris di masa Perdana Menteri Margareth Thatcher dan di Amerika Serikat di bawah Presiden Ronald Reagan. Pengurangan peran negara dilakukan Thatcher terhadap empat wilayah publik, yaitu: pelayanan kesehatan, pendidikan, santunan pengangguran dan pensiunan hari tua. Berbeda dengan di masa sebelum 1970 yang berparadigma state-led development, pemangkasan peran negara setelah kemenangan Kelompok Neoliberal di Eropa dan Amerika Serikat menggeser cara pandang kebijakan menjadi market-led development.

Kritikan terhadap paradigma pembangunan yang selama ini diterapkan dan pemangkasan peran negara dalam pembangunan ini dilancarkan oleh kalangan yang berperspektif radikal. Hal ini karena globalisasi menurut kelompok ini dipahami sebagai sejarah baru yang terjadi 
dalam kehidupan manusia yang menempatkan negara tradisional menjadi tidak lagi relevan, terutama dalam konteks unit-unit bisnis yang ada dalam sebuah ekonomi global. Bagi kaum radikal, batas-batas negara bukan waktunya lagi untuk dijadikan topik bahasan karena globalisasi sudah meluluhlantakkannya. Di samping itu, dominannya peran negara dalam urusan-urusan perekonomian sebagaimana yang dipraktikkan sebelum tahun 1970 diklaim sebagai kekangan dan kungkungan yang menghambat efisiensi penggunaan sumberdaya-sumberdaya dunia yang langka.

Kenichi Ohmae merupakan salah satu tokoh radikal yang mengusulkan pemangkasan peran negara agar tujuantujuan globalisasi dalam digapai dengan sukses. Terkait dengan ini, Ohmae mengajukan empat alasan yang memperkuat pandangannya mengenai marginalisasi peran negara yang disebutnya sebagai Faktor "i". Investasi merupakan faktor "i" pertama, karena sebaran dana dapat menyebar ke tempat-tempat yang justru berada di luar wilayah asal dana tersebut. Faktor "i" kedua adalah industri, karena ekspansinya sudah tidak mengenal lagi batas-batas negara, tetapi berdasarkan pada pertimbangan pangsa pasar sehingga banyak perusahaan yang justru beroperasi jauh berada di luar wilayah asalnya. Teknologi informasi menjadi faktor "i" ketiga, karena pesatnya perkembangan kedua entitas ini sehingga mampu melintasi batas-batas negara, bahkan hanya dalam hitungan detik saja. Faktor "i" terakhir yang memperkuat pandangan Ohmae akan marginalisasi peran negara adalah konsumen-konsumen individual yang berorientasi global sudah dapat mengakses berbagai kebutuhan di seluruh dunia karena kemajuan teknologi informasi, tanpa terhambat oleh batas-batas negara.

Diskursus peran negara dalam pembangunan di era globalisasi ternyata belum berakhir dengan bergesernya kebijakan menjadi market-led development yang didukung oleh beberapa kalangan. Menurut Holton dan Wolf, pemangkasan peran negara dalam globalisasi justru melupakan sejarah karena perkembangan pesat globalisasi yang dijadikan alasan kelompok pendukungnya tidak dapat disangkal merupakan peran negara. Negara-negara yang menjadi aktor utama globalisasi (Amerika Utara, Eropa Barat dan Asia Timur) saat ini bisa mendapatkan keuntungan yang 
besar melalui korporasi-korporasi dan lembaga-lembaga internasional merupakan implikasi dari peran negara melalui beragam kebijakan yang dihasilkannya. Di samping itu, Holton dan Wolf juga mengatakan bahwa korporasi-korporasi dan lembaga-lembaga internasional yang menjadi agen utama globalisasi tentu membutuhkan arena wilayah untuk memainkan peranannya yang tentunya secara politik diwakili oleh negara.

Masih dalam konteks yang sama, Singh juga mengatakan bahwa peran negara justru semakin kuat dan sangat layak untuk dikemukakan di era globalisasi. Sebagai upaya menguatkan pendapatnya, Singh mengajukan beberapa alasan pembenar terkait semakin menguatnya peran negara di tengah masifnya kegiatan globalisasi di seluruh dunia. Alasan pertama, tidak semua negara berkurang atau melemah peranannya di era globalisasi, karena tingkatannya sangat berbeda antara satu negara dengan negara lainnya, tergantung dengan ukuran, kekuatan militer, dan kekuatan negara. Sebagai kekuatan utama dunia dan aktor utama globalisasi, peran Amerika Serikat tentu tidak melemah dibandingkan dengan beberapa negara Dunia Ketiga yang ada di Asia dan Afrika karena tingkatan ukuran, kekuatan militer dan kekuatan negaranya sangat berbeda.

Faktor penguat kedua adalah secara finansial ongkos yang harus dikeluarkan pemerintah untuk menjadi bagian dari globalisasi tidak begitu signifikan menggerogoti keuangan negara. Hal ini karena sebuah negara yang semakin terintegrasi dengan negara-negara lainnya, maka pengeluaran negara akan cenderung bertambah daripada berkurang. Faktor ketiga, privatisasi sektor publik yang menjadi prasyarat bagi globalisasi yang disyaratkan oleh salah satu aktornya (IMF) bukan berarti penolakan terhadap intervensi negara. Hal ini karena, meskipun privatisasi di satu sisi dapat menyebabkan penurunan kepemilikan publik, namun di lain sisi kebijakan ini akan berdampak pada peningkatan regulasi negara melalui pembentukan otoritas, kebijakan regulasi persaingan, norma keterbukaan, dan langkah-langkah kebijakan baru lainnya. Faktor terakhir, meskipun peran negara akan berkurang pada aspek ekonomi, namun disektorsektor lain peran negara akan meningkat secara signifikan, seperti meningkatnya sikap represif negara 
terhadap rakyatnya yang melakukan protes terhadap program pemerintah yang dianggap menguntungkan korporasi asing.

Memperkuat pandangan-pandangan di atas, Budi Winarno mengajukan dua alasan yang mendasari sangat signifikannya peran negara di era globalisasi ini. Pertama, sebagai implikasi dari kolonialisme di masa lalu dan globalisasi di masa sekarang ini, banyak rakyat di Dunia Ketiga yang masih bergelimang dengan ketidakberdayaan dan kemiskinan. Kondisi ini tentu membutuhkan peran negara untuk melakukan pembangunan yang dapat meningkatkan taraf hidup mereka agar bisa sejajar dengan negara-negara lainnya. Kedua, sistem globalisasi melalui mekanisme pasar tidak boleh dibiarkan terus mendominasi setiap aspek kehidupan rakyat karena cara ini tidak menjamin keadilan dalam distribusi pendapatan rakyat. Agar masing-masing rakyat mendapatkan haknya untuk hidup secara lebih baik maka diperlukan peran negara yang mengatasinya melalui pembangunan yang mendukung terpenuhinya aspirasi rakyat.

Budi Winarno lebih lanjut juga mengungkapkan fakta beberapa negara yang pernah dihantam krisis dan mampu mengatasinya karena peran efektif pemerintahnya, seperti yang terjadi di Korea Selatan dan Malaysia. Melalui tindakan

pemerintah dengan seperangkat birokrasinya yang efektif, Korea Selatan dan Malaysia berhasil mengatasi krisis moneter dan ekonomi yang melanda keduanya serta mampu bangkit dari keterpurukan. Sebaliknya, oleh karena ketiadaan peranan yang efektif dari negara sebagaimana yang ditunjukkan oleh Korea Selatan dan Malaysia, Indonesia tidak berhasil mengatasi krisis moneter serta ekonomi yang membelitnya dan dampaknya masih dapat dirasakan sampai sekarang.

Berlandaskan pada pandangan kalangan skeptis dengan sederet argumentasi dan faktanya di atas, maka dapat disimpulkan bahwa peran negara dalam pembangunan justru harus tetap ada atau harus diperkuat. Terkait dengan diskursus peran signifikan negara dalam mengatasi masalahmasalah publik ini, maka paradigma New Publik Service (NPM) layak dikedepankan. Konsep yang diusung oleh Janet V. Dernhart dan Robert B. Dernhart ini merupakan kritikan terhadap Reinventing Government yang diajukan oleh David Osborne dan Ted Gaebler. Sebagai kritikan terhadap bentuk 
lain dari New Publik Management (NPM) yang menjadi paradigma mainstream dalam diskursus peran Negara ini, NPS mengganggap bahwa menjalankan administrasi pemerintahan tidaklah sama dengan mengelola organisasi bisnis, hal ini karena harus digerakkan sebagaimana menggerakkan pemerintahan yang demokratis. Misi organisasi publik tidak sekedar memuaskan pengguna jasa (customer), tetapi juga menyediakan pelayanan barang dan jasa sebagai pemenuhan hak dan kewajiban publik.

Berbeda dengan Reinventing Governance yang diusung NPM, Paradigma NPS memperlakukan publik pengguna layanan publik sebagai warga negara (citizen), bukan sebagai pelanggan (customer). Peran negara yang dijalankan oleh para birokratnya tidak sekedar melakukan kegiatan yang dapat memuaskan pelanggan, tetapi juga memberikan hak warga negara dalam mendapatkan pelayanan publik. Perspektif yang diusung NPS ini diilhami oleh warisan intelektual yang dipersembahkan oleh orangorang yang menaruh perhatian terhadap pelayanan publik. Menurut Dernhart, kelahiran NPS terinspirasi oleh 4 (empat) komponen yang lebih kontemporer dari layanan publik, yaitu: (1) teori warga negara demokratis, (2) model komunitas dan masyarakat sipil, (3) humanisme organisasional dan administrasi publik baru, dan (4) administrasi publik modern.

Paradigma NPS memandang penting keterlibatan banyak aktor dalam penyelenggaraan urusan publik. Dalam administrasi publik apa yang dimaksud dengan kepentingan publik dan bagaimana kepentingan publik diwujudkan tidak hanya tergantung pada lembaga negara. Kepentingan publik harus dirumuskan dan diimplementasikan oleh semua aktor baik negara, bisnis, maupun masyarakat sipil.

Berdasarkan paradigma NPS, peran negara yang dijalankan

oleh para birokratnya dilaksanakan berdasarkan prinsipprinsip sebagaimana berikut ini:

Melayani Warga Negara, bukan Pelanggan: Kepentingan publik adalah hasil suatu dialog tentang nilainilai bersama ketimbang kumpulan kepentingan-diri individual. Oleh karena itu, pelayan publik tidak hanya bertanggungjawab kepada tuntutan "para pelanggan", tetapi lebih tepatnya berfokus pada pembangunan hubungan 
kepercayaan dan kolaborasi dengan dan di antara warga negara;

Mengusahakan Kepentingan Publik: Para administrator publik harus member sumbangan untuk membangun suatu gagasan kolektif kepentingan publik yang dianut bersama. Tujuannya ialah bukan untuk menemukan solusi-solusi cepat yang didorong oleh pilihan-pilihan individual. Lebih tepatnya, adalah menciptakan kepentingankepentingan bersama dan tanggungjawab bersama;

Menghargai Warga Negara melebihi Kewirausahaan: Kepentingan publik lebih baik dimajukan oleh pelayan publik dan warga negara yang bertekad memberikan sumbangan bermakna kepada masyarakat ketimbang oleh manajer usahawan yang bertindak seakan-akan uang publik itu adalah milik mereka sendiri;

Berpikir Secara Strategis, Bertindak Secara Demokratis: Kebijakan dan program memenuhi kebutuhan publik dapat dicapai secara paling efektif dan paling bertanggungjawab melalui usaha kolektif dan proses kolaboratif;

Mengakui bahwa Akuntabilitas tidak Sederhana: Pelayan publik harus lebih memerhatikan ketimbang pasar; mereka juga harus mematuhi undang-undang dan hukum konstitusional, nilai komunitas, norma politik, standar professional, dan kepentingan warga negara;

Melayani bukan Menyetir: Semakin penting bagi para pelayan publik untuk menggunakan kepemimpinan berbasis nilai yang dianut bersama dalam membantu warga negara mengutarakan secara jelas dan memenuhi kepentingan bersama mereka ketimbang berusaha mengendalikan atau menyetir masyarakat dalam arah-arah yang baru;

Menghargai Manusia, Bukan Sekedar Produktivitas: Organisasi publik dan jaringan tempat mereka berpartisipasi lebih mungkin berhasil dalam jangka panjang jika mereka bekerja melalui proses-proses kolaborasi dan kepemimpinan bersama yang didasarkan pada penghargaan terhadap semua orang.

Berdasarkan perspektif NPS di atas, maka dapat disimpulkan bahwa bahwa birokrasi harus dibangun agar dapat memberikan perhatian kepada pelayanan masyarakat sebagai warga negara (bukan sebagai pelanggan), 
mengutamakan kepentingan umum, mengikutsertakan warga masyarakat, berpikir strategis dan bertindak demokratis, memerhatikan norma, nilai dan standar yang ada dan menghargai masyarakat dalam artian keterlibatan masyarakat menjadi sesuatu yang sangat penting.

Mengadopsi konsep New Publik Service (NPS) di atas, maka dapat dikatakan bahwa peran negara/pemerintah justru akan semakin signifikan di era globalisasi. Implementasi dari konsep New Publik Service (NPS) ini pada satu sisi akan membuat negara/pemerintah melalui birokrasinya mampu menyikapi perubahan-perubahan yang senantiasa terjadi dalam skala global secara arif dan bijaksana, serta di sisi lainnya akan dapat memenuhi tuntutan-tuntutan dan kebutuhan-kebutuhan masyarakat akan pelayanan publik yang prima. Hal ini karena masyarakat harus mendapatkan pelayanan yang baik sebagai warga negara, bahkan harus lebih baik dari pelayanan yang diberikan terhadap seorang pelanggan.

Penyikapan pemerintah terhadap perubahanperubahan yang terjadi di skala global tersebut tentu akan diikuti dengan lahirnya kebijakan-kebijakan yang mendukung kepentingan rakyat, sehingga perannya sebagai pelayan masyarakat tetap terus berlangsung. Pada konteks ini, seiring dengan arus globalisasi yang melahirkan banyak persoalan (dampak negatifnya), seharusnya pemerintah harus berperan lebih dominan dalam membantu rakyat mengatasi beragam problem yang mereka hadapi.

Tidak seperti sistem birokrasi lama yang menyerahkan sepenuhnya kepada mekanisme pasar, tetapi pemerintah harus berinovasi melahirkan kebijakan solutif bagi terpecahkannya persoalan-persoalan yang dialami rakyat dalam hubungannya dengan globalisasi. Berlandaskan pada konsep New Publik Service (NPS), pemerintah melalui sistem birokrasi yang dimilikinya bersama dengan stakeholders lainnya seharusnya mampu berinovasi menciptakan terobosan solusi bagi masalah yang dihadapi rakyat.

Salah satu contoh yang dapat diterapkan bagaimana signifikannya peran pemerintah di era globalisasi adalah terkait dengan petani karet. Melalui implementasi peranannya, pemerintah dapat membalikkan posisi karet yang selama ini diperuntukkan bagi ekspor (80 persen), 
menjadi pemenuhan kebutuhan dalam negeri. Upaya ini dapat dilakukan dengan cara pemerintah mengambil kebijakan pemanfaatan karet untuk memenuhi keperluan dalam negeri, campuran aspal salah satunya.

Oleh karena dalam negeri sendiri yang memanfaatkannya, maka penghasilan petani karet akan meningkat karena harga karet yang selama ini ditentukan sepenuhnya oleh negara-negara pengimpor, dapat ditetapkan sendiri oleh pemerintah sebagai pengguna utamanya. Contoh lainnya adalah kebijakan-kebijakan pembangunan berbasis potensi lokal yang diterapkan oleh Pemerintah Kabupaten Merangin, seperti pengembangan wisata alam, revitalisasi lubuk larangan dan lain sebagainya.

Atau kebijakan-kebijakan berbasis potensi dan kebutuhan masyarakat perkotaan yang diterapkan oleh Pemerintah Kota Jambi melalui Kampung Bantar dan lain sebagainya. Pendek kata, pemerintah, khususnya pemerintah daerah pasca otonomi daerah dapat berperan secara optimal melalui serangkaian kebijakan inovatif-solutifnya agar kesejahteraan masyarakat dapat terwujud. 


\section{DAFTAR PUSTAKA}

Arjoso, Amin . 2000. Pancasila Dasar Falsafah Negara. Yayasan Kepada Bangsaku.

Jakarta.

Chautard, Sophie. 2009. La Geopolitique. 2e edition. Studyrama.

Dahana, Radhar Panca. 2011. "Saya Mohon Ampun" dalam Kompas, 20 April 2011, Jakarta.

Franedya, R. (2020, Agustus 25). Berapa Pengguna Aktif TikTok di Dunia? Jangan Kaget Yah! Retrieved from CNBC Indonesia: https://www.cnbcindonesia.com/tech/20200825104121 -37-181742/berapa-pengguna-aktif-tiktok-di-duniajangan-kaget-yah

G. Ó Tuathail. 1996. Critical Geopolitics: The Politics of Writing Global Space. Minneapolis: University of Minnesota Press (Volume 6 in the Borderlines series) and London: Routledge.

Giddens, A. (1990). The Consequences of Modernity. Cambridge. Polity Press.

Hargens, Boni. 2011. "Indonesia, 'Halo Soekarno" dalam Kompas, 16 April 2011, Jakarta.

Jati, Wasisto Raharjo. 2011. "Pembangunan Gerus Kearifan Lokal” dalam Kompas, 20 April 2011, Jakarta.

Kansil, CST dan Kansil, Christine ST . 2001. Pancasila dan Undang - Undang Dasar 1945. Pradnya Paramita, Jakarta.

Lemhannas RI. 2012. Geostrategi dan Ketahanan Nasional. Jakarta.

Lemhannas RI. 2012. Wawasan Nusantara. Jakarta.

Muhtadi, Dedi. 2011. "Ketika Kearifan Lokal Tergerus Zaman" dalam Kompas, 23 April 2011, Jakarta.

Mumford, Andrew. 2013. Proxy Warfare. Polity Press. Cambridge.

Purnomo Yusgiantoro, Ceramah Menteri Pertahanan RI di depan anggota HIPMI pada Kegiatan Pemantapan Nilai-Nilai Kebangsaan di Lemhannas RI 18 Februari 2014.

Ruland, Jurgen, 2012. The Politics of Military Reform. Springer. London.

Selo Soemardjan dan Soleman. (1974). Setangkai Bunga Sosiologi, Jakarta: Yayasan Badan Penerbit Fakultas Ekonomi UI.

Simatupang, T. (2020, Januari 20). Pendapatan TikTok meroket sepanjang 2019. Retrieved from lokadata.id: 
https://lokadata.id/artikel/pendapatan-tik-tok-meroketsepanjang-2019Soemardi (ed),

Soekarno, Ir. 2012. Susunlah Pertahanan Nasional Bersendikan Karakteristik Bangsa - Amanat Presiden Soekarno pada Peresmian Lembaga Pertahanan Nasional di Istana Negara, tanggal 20 Mei 1965. Jakarta.

Soepandji, Budi Susilo, Indonesia Menyongsong Abad Asia Pasifik Jilid II Dalam Perspektif Ketahanan Nasional, Makalah Gubernur Lemhannas RI pada Seminar Nasional Gerakan Mahasiswa Nasional Indonesia, 3 Mei 2014.

Soepandji, Budi Susilo, Membangun Pondasi Dasar Nasionalisme, Makalah Gubernur Lemhannas RI pada Indonesian Fellowship Youth Camp 2012, tanggal 28 November 2014. Soepandji, Budi Susilo, Peran Strategis Menwa Yang Berkemampuan Teknologi Sebagai Bagian dari Potensi Ketahanan Nasional, Makalah Gubernur Lemhannas RI pada Sarasehan dan Seminar Nasional 50 Tahun Menwa ITB “Resimen Teknologi” 22 Maret 2014.

Soepandji, Budi Susilo, Peran Strategis Menwa Yang Berkemampuan Teknologi Sebagai Bagian dari Potensi Ketahanan Nasional, Makalah Gubernur Lemhannas RI pada Sarasehan dan Seminar Nasional 50 Tahun Menwa ITB “Resimen Teknologi” 22 Maret 2014. 
232 